\title{
Hydrogeologic Evaluation and \\ Numerical Simulation of the Death Valley \\ Regional Ground-Water Flow System, \\ Nevada and California
}

By Frank A. D'Agnese, Claudia C. Faunt, A. Keith Turner, and Mary C. Hill

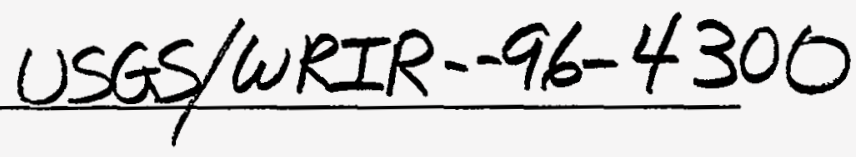

\section{U.S. GEOLOGICAL SURVEY}

Water-Resources Investigations Report 96-4300

Prepared in cooperation with the NEVADA OPERATIONS OFFICE, U.S. DEPARTMENT OF ENERGY, under Interagency Agreement DE-Al08-92NV10874

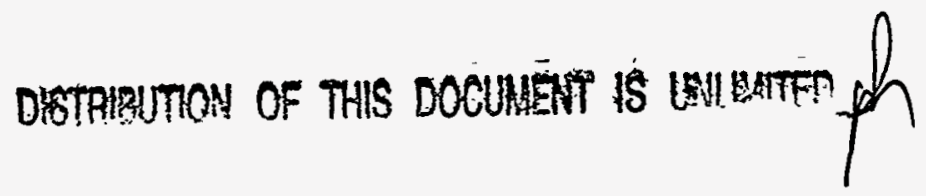

Denver, Colorado 1997

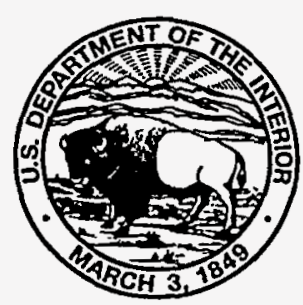




\section{U.S. DEPARTMENT OF THE INTERIOR \\ BRUCE BABBITT, Secretary}

U.S. GEOLOGICAL SURVEY

Gordon P. Eaton, Director

The use of firm, trade, and brand names in this report is for identification purposes only and does not constitute endorsement by the U.S. Geological Survey.

For additional information write to:

Chief, Earth Science Investigations Program Yucca Mountain Project Branch

U.S. Geological Survey

Box 25046, Mail Stop 421

Denver Federal Center

Denver, CO 80225-0046
Copies of this report can be purchased from:

U.S. Geological Survey Branch of Information Services

Box 25286

Denver, CO 80225-0286 


\section{DISCLAIMER}

This report was prepared as an account of work sponsored by an agency of the United States Government. Neither the United States Government nor any agency thereof, nor any of their employees, makes any warranty, express or implied, or assumes any legal liability or responsibility for the accuracy, completeness, or usefulness of any information, apparatus, product, or process disclosed, or represents that its use would not infringe privately owned rights. Refesence herein to any specific commercial product, process, or service by trade name, trademark, manufacturer, or otherwise does not necessarily constitute or imply its endorsement, recommendation, or favoring by the United States Government or any agency thereof. The views and opinions of authors expressed herein do not necessarily state or reflect those of the United States Government or any agency thereof. 


\section{DISCLAIMER}

Portions of this document may be illegible electronic image products. Images are produced from the best available original document. 


\section{CONTENTS}

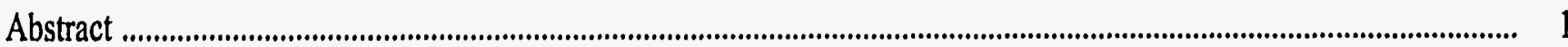

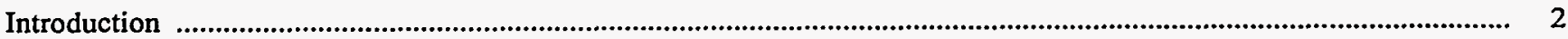

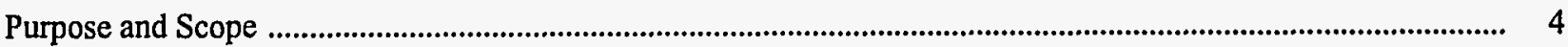

Quality-Assurance Considerations ............................................................................................................................. 4

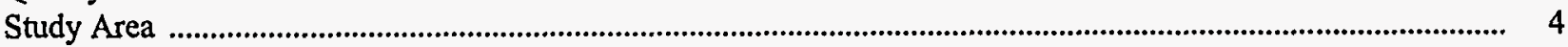

Previous Work in the Death Valley Region ............................................................................................................... 4

Geologic and Structural Investigations ............................................................................................................ 5

Hydrogeologic Investigations .......................................................................................................................... 5

Previous Ground-Water Models of the Death Valley Region .............................................................................. 6

Site Description

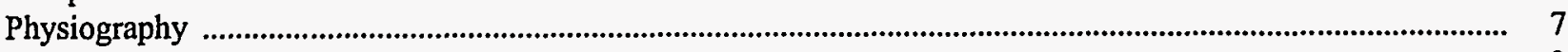

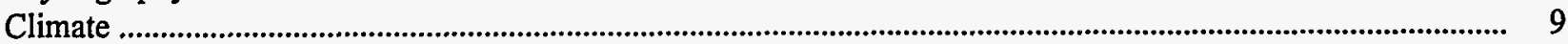

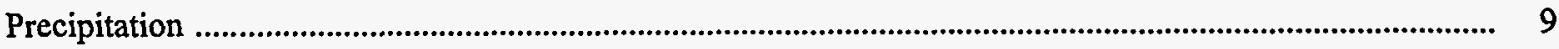

Air Temperature and Humidity ........................................................................................................................ 11

Soils and Vegetation ............................................................................................................................................ 11

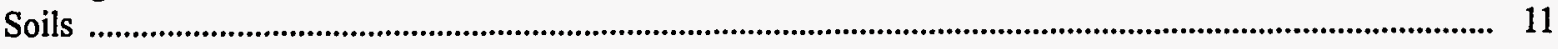

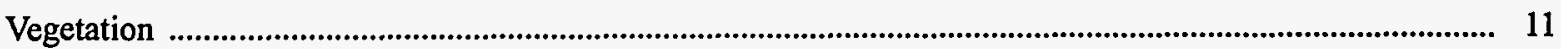

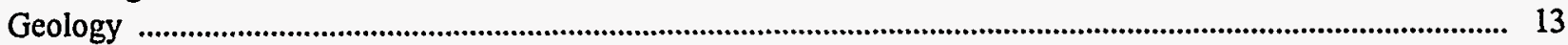

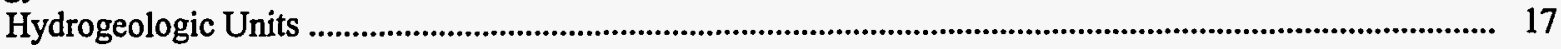

Quaternary Playa Deposits ................................................................................................................... 17

Quaternary-Tertiary Valley Fill ............................................................................................................... 17

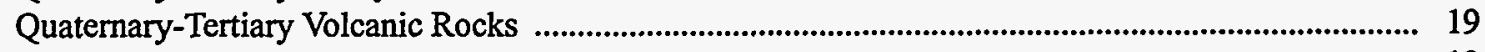

Tertiary Volcanic Rocks .................................................................................................................... 19

Tertiary Volcanic and Volcaniclastic Rocks ........................................................................................... 19

Tertiary-Late Jurassic Granitic Rocks ................................................................................................. 19

Mesozoic Sedimentary and Metavolcanic Rocks .................................................................................. 19

Paleozoic Carbonate Rocks ...................................................................................................................... 20

Paleozoic-Precambrian Clastic Rocks ............................................................................................. 20

Precambrian Igneous and Metamorphic Rocks ..................................................................................... 20

Hydrology ................................................................................................................................................................... 20

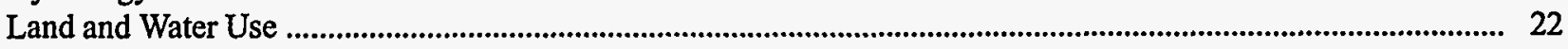

Use of Geoscientific Information Systems ............................................................................................................... 22

Geoscientific Information Systems (GSIS) .......................................................................................................... 22

Relationship Between GSIS and GIS ............................................................................................................ 22

Classes of GSIS .............................................................................................................................................. 23

Role of GSIS ....................................................................................................................................... 23

GSIS Software Products Used in the Project .............................................................................................. 23

Design of GSIS Centralized Data Base ......................................................................................................................... 27

Definition of Data Categories ...................................................................................................................... 27

Data Categories Defining the Hydrogeologic Framework ............................................................................. 29

Data Categories Defining Surface and Subsurface Hydrologic Conditions ...................................................... 29

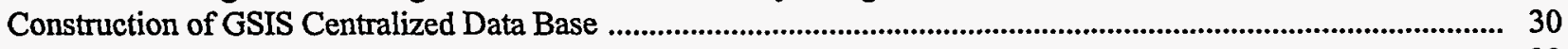

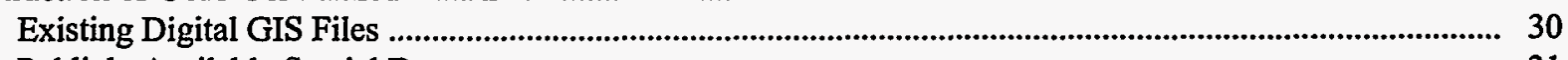

Publicly Available Spatial Data ...................................................................................................................... 31

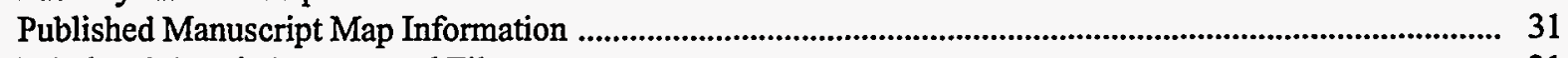

Tabulated Data in Reports and Files ............................................................................................................ 31

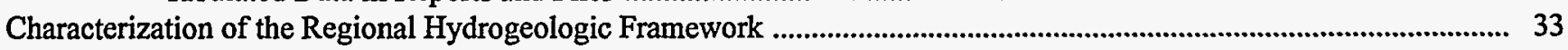

Construction of 3D Digital Hydrogeologic Framework Model ................................................................................... 33

Integration of DEM and Geologic Map Data ........................................................................................................ 33

Use of Cross Sections and Well-Log Data ....................................................................................................... 33

Interpolation of Structural Surfaces for Hydrogeologic Units .................................................................... 35 


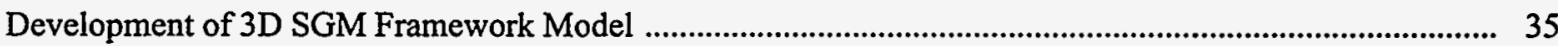

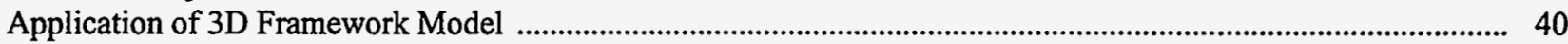

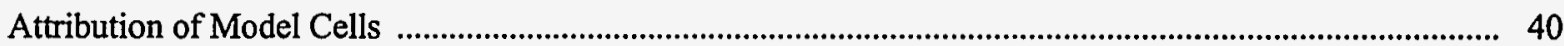

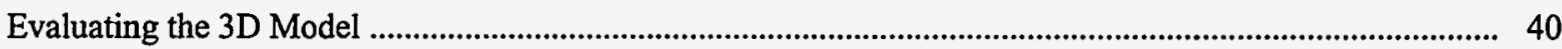

Examination of the 3D Digital Hydrogeologic Framework Model ......................................................... 40

Defining the 3D Distribution of Hydraulic Properties ............................................................................. 40

Characterization of Regional Hydrologic Conditions ................................................................................................... 43

Characterizing the Discharge Component .................................................................................................................... 43

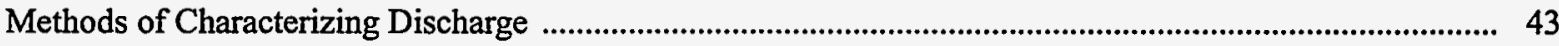

Characterization and Estimation of Evapotranspiration Volumes ................................................................. 43

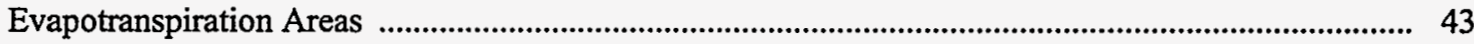

Evapotranspiration Rates and Flux Estimation .............................................................................. 44

Spring Discharge Accounting ...................................................................................................................... 44

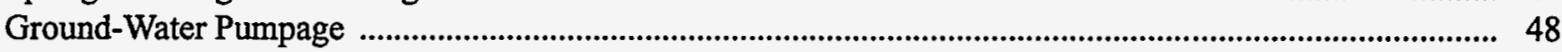

Characterizing the Recharge Component ................................................................................................................... 50

Previous Methods of Characterizing Recharge ......................................................................................... 50

Limitations of the Empirical Maxey-Eakin Method ............................................................................... 52

Modifying the Maxey-Eakin Method ................................................................................................................... 52

Refined Recharge Estimation ....................................................................................................................... 55

Accuracy and Suitability of Refined Method .................................................................................................. 55

Evaluation of Current Recharge Estimate ........................................................................................................... 55

Characterizing the Regional Potentiometric Surface .............................................................................................. 56

Previous Potentiometric-Surface Maps .................................................................................................. 56

Construction of an Estimated Regional Potentiometric-Surface Map ........................................................ 57

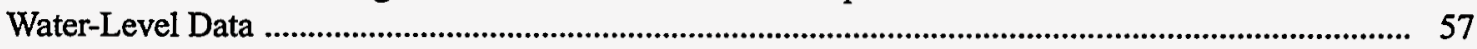

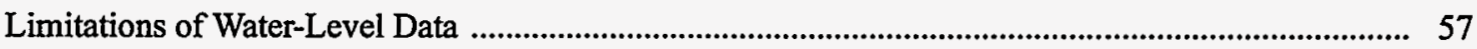

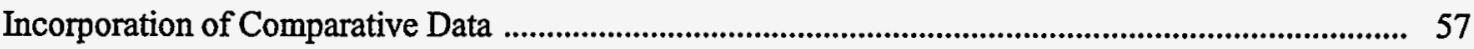

Conceptualization of Regional Ground-Water Flow ......................................................................................................... 59

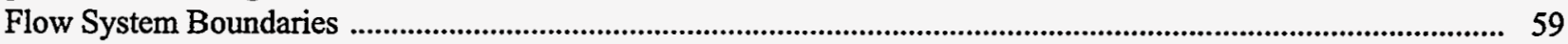

Regional Boundaries .......................................................................................................................... 59

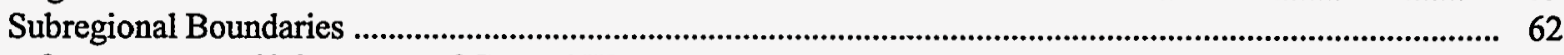

Source, Occurrence, and Movement of Ground Water ....................................................................................... 62

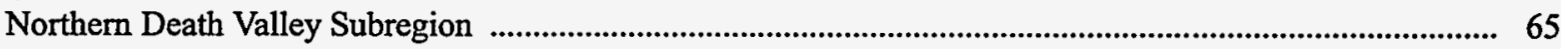

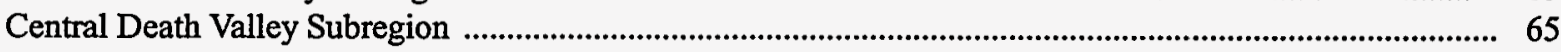

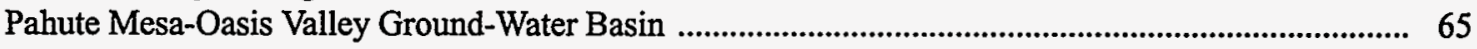

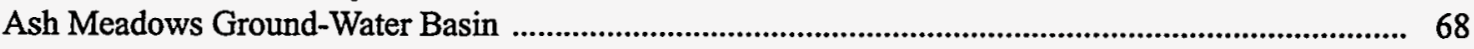

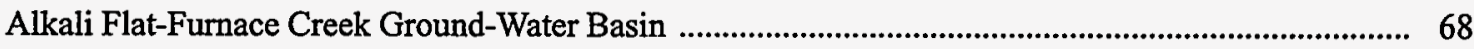

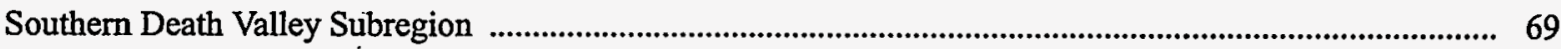

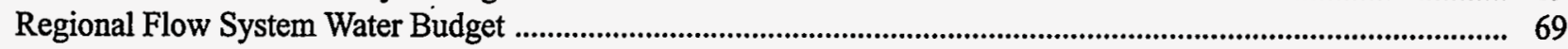

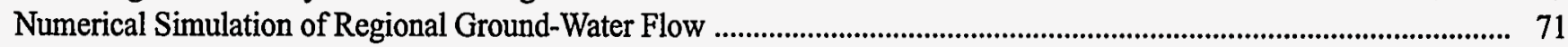

Numerical Modeling Difficulties and Simplifying Assumptions .......................................................................... 72

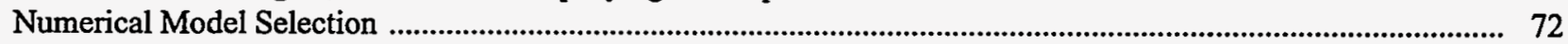

Nonlinear Regression Objective Function ............................................................................................... 73

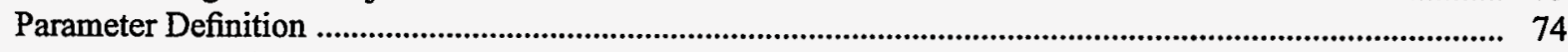

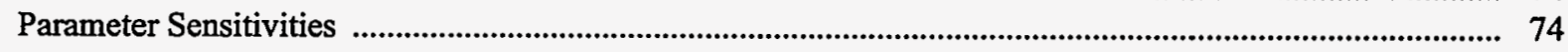

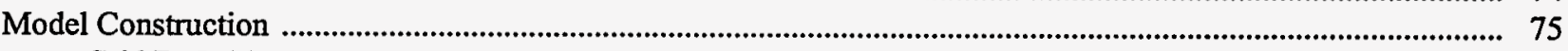

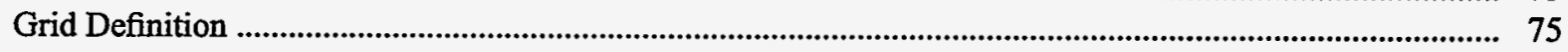

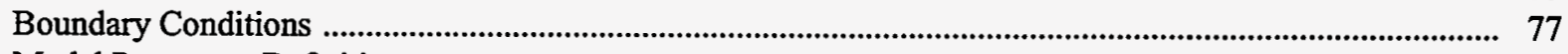

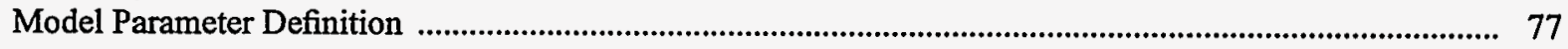

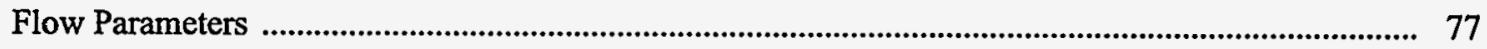

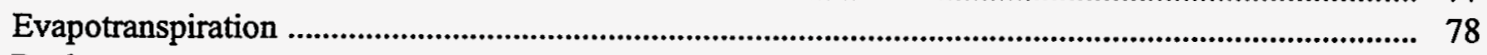

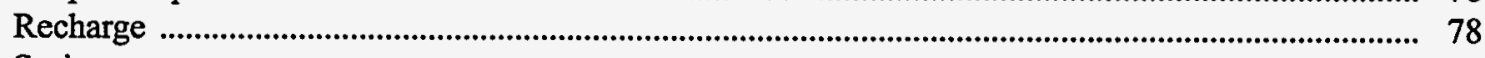

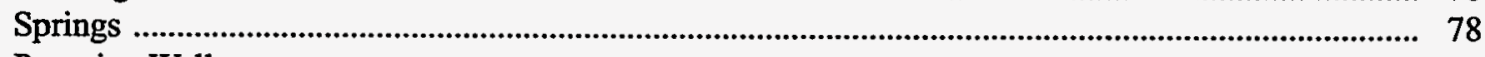

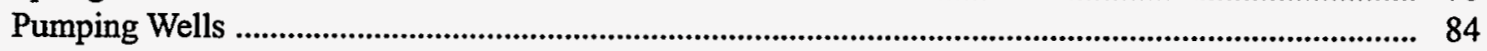




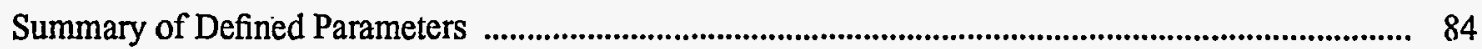

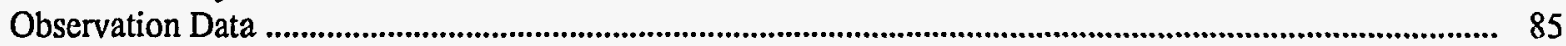

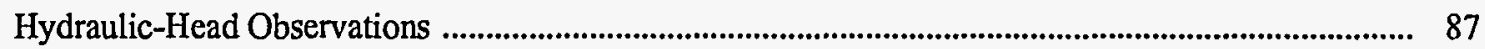

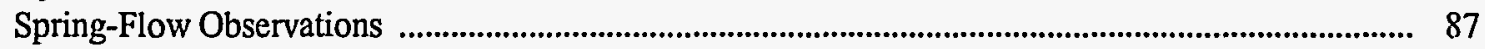

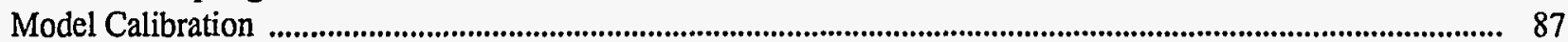

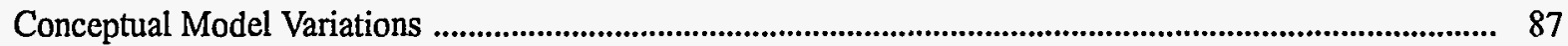

Location and Type of Boundary Conditions .............................................................................................. 88

Definition of Extent of Recharge Areas ........................................................................................ 88

Variations in Interpretation of Hydrogeologic Framework ................................................................ 88

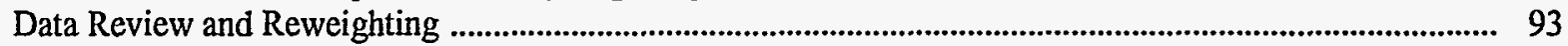

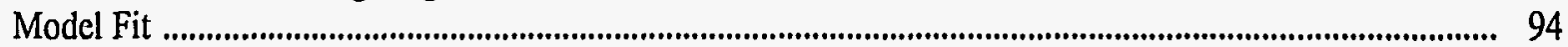

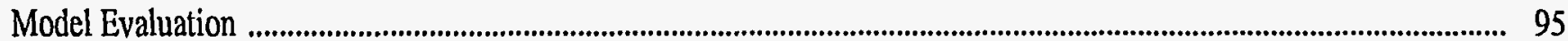

Hydraulic Heads and Spring Flows ............................................................................................................................ 95

Spatial Distribution of Residuals and Weighted Residuals .............................................................................. 104

Distribution of Residuals and Weighted Residuals Relative to Weighted Simulated Values .......................... 104

Normality of Weighted Residuals and Model Linearity .......................................................................................... 106

Estimated Parameter Values ........................................................................................................................................ 106

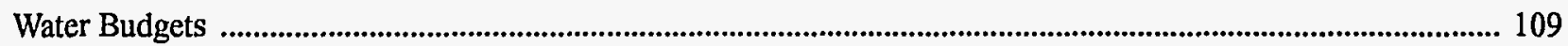

Summary of Model Evaluation ........................................................................................................................ 112

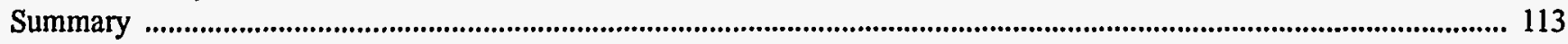

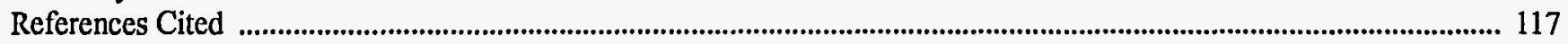

\section{FIGURES}

1-9. Maps showing:

1. Geographic features of the Death Valley region.................................................................................................. 3

2. Prominent topographic features of the Death Valley region ......................................................................... 8

3. Desert climatic zones of the Death Valley region ............................................................................................ 9

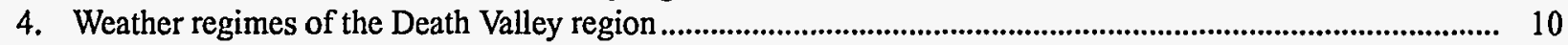

5. Vegetation zones of the Death Valley region......................................................................................................... 12

6. Tectonic features of the Death Valley region and vicinity..............................................................................

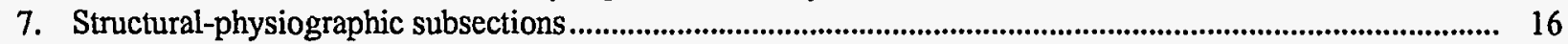

8. Hydrogeologic units of the Death Valley region .................................................................................................... 18

9. Hydrographic areas of the Death Valley region ........................................................................................................ 21

10-13. Diagrams showing:

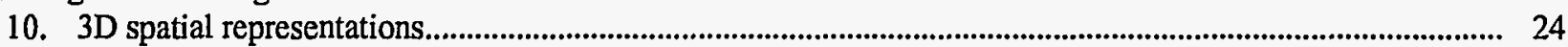

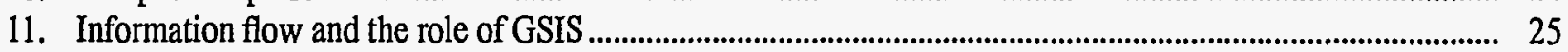

12. Integration of commercial GIS, GSIS, and gridding and contouring software used by the project................... 26

13. Data categories selected and incorporated into standardized GSIS data base................................................... 28

14. Graph showing map sheets used to compile surface geologic data .......................................................................... 30

15. Map showing locations of subsurface data used to construct the hydrogeologic framework model.......................... 32

16. Diagram showing 3D perspective diagram of partially attributed hydrogeologic cross sections ............................... 34

17. Map showing traces of mapped regional faults................................................................................................. 36

18. Map showing traces of features used to create $3 D$ hydrogeologic framework model ............................................... 37

19. Diagram showing perspective view of 2.5D surface of carbonate aquifer (P2) .................................................... 38

20. Diagram showing time-stratigraphic and model order of geologic events .............................................................. 39

21. Fence diagram showing regional hydrogeologic units................................................................................................. 41

22. Graph showing hydraulic conductivity distributions estimated for major rock types in the

Death Valley region

23-32. Maps showing:

23. Final evapotranspiration areas in the Death Valley region..........................................................................4 45

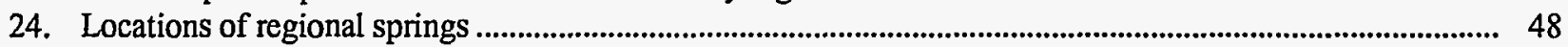

25. Refined potential recharge areas for the Death Valley region ........................................................................ 54

26. Locations of water-level-data wells in the Death Valley region.............................................................................. 58 
27. Estimated potentiometric surface of the Death Valley region

28. Locations of regional inflows across flow system boundaries

29. The three subregions of the Death Valley regional ground-water flow system that encompass the area modeled in this study

30. Subregions, ground-water basins, and associated flow paths of the Death Valley regional ground-water flow system

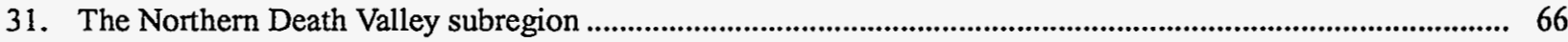

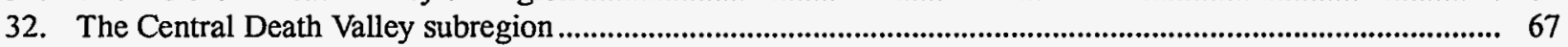

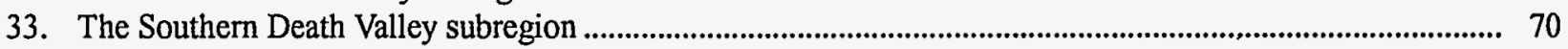

34. Diagram showing generic MODFLOWP model grid........................................................................................ 73

35. Diagram showing example of VCONT array organization .................................................................................. 74

36. Map showing model boundary conditions-constant heads, springs, wells ......................................................... 76

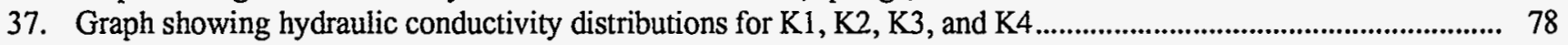

38-42. Maps showing:

38. Layer 1 initial conductivity zones.......................................................................................................... 79

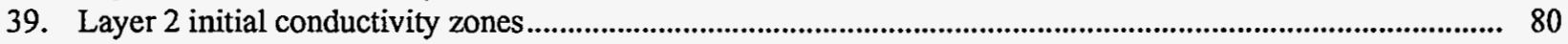

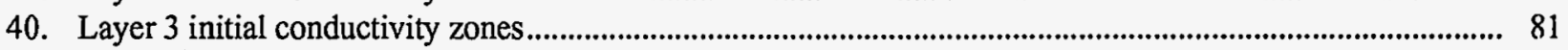

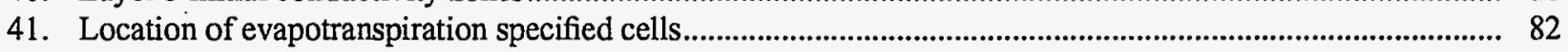

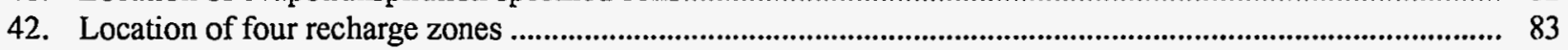

43. Graph showing composite scaled sensitivities of initial model................................................................................... 85

44. Map showing layer 1 final hydraulic conductivity zones ........................................................................................ 88

45. Graph showing composite scaled sensitivities of initial model showing relative high sensitivity of parameters $\mathrm{K} 3$ and $\mathrm{K} 4$

46-55. Maps showing:

46. Layer 2 final hydraulic conductivity zones...................................................................................................... 91

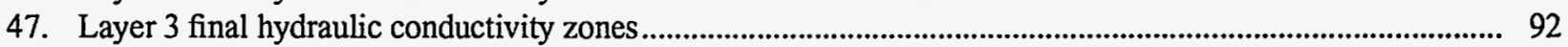

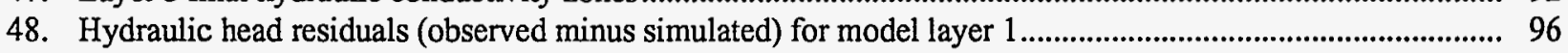

49. Hydraulic head weighted residuals (observed minus simulated) for model layer 1 ....................................... 97

50. Hydraulic head residuals (observed minus simulated) for model layer 2 ....................................................... 98

51. Hydraulic head weighted residuals (observed minus simulated) for model layer 2 ...................................... 99

52. Hydraulic head residuals (observed minus simulated) for model layer 3...................................................... 100

53. Hydraulic head weighted residuals (observed minus simulated) for model layer 3 ......................................... 101

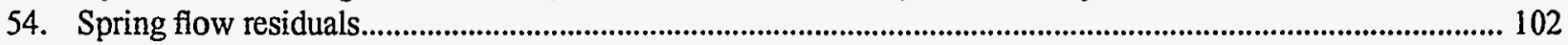

55. Spring flow weighted residuals.............................................................................................................. 103

56-60. Graphs showing:

56. Weighted residuals against weighted simulated values .................................................................................... 105

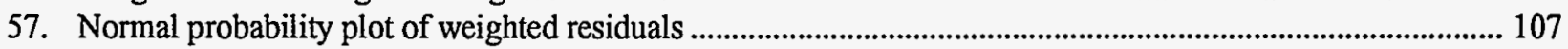

58. Normal probability plot of correlated normal random deviates.................................................................. 108

59. Estimated hydraulic conductivity parameters, their 95-percent linear confidence intervals, and the range of reasonable values ....................................................................................................... 110

60. Composite scaled sensitivities for estimated parameters in the final calibrated model ...................................... 111

\section{TABLES}

1. Estimated hydraulic conductivity of hydrogeologic units ................................................................................. 17

2. Estimated evapotranspiration and spring discharge rates by discharge area .........................................................4. 46

3. Reported regional spring data for Death Valley region ......................................................................................... 47

4. Water-use estimates for selected hydrographic areas .......................................................................................... 49

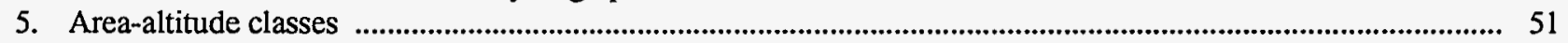

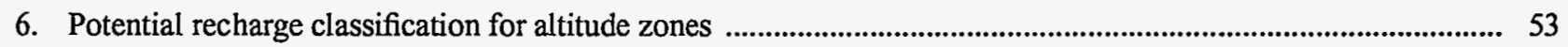

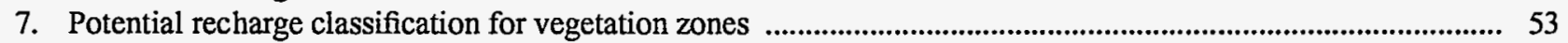

8. Potential recharge classification for slope-aspect zones .......................................................................................... 53

9. Potential recharge classification for parent material types .................................................................................. 53

10. Final recharge potential zones and relative recharge percentages .......................................................................... 55 
11. Comparisons of recharge estimates for this study with Maxey-Eakin estimates ............................................... 56

12. Divisions of the Death Valley regional ground-water flow system ....................................................................

13. Adjusted regional water budget for the Death Valley regional ground-water flow system ................................ 71

14. Final conductance parameters (GHB) for large volume spring discharge.......................................................... 84

15. Initial defined parameters and initial values for the DVRFS model ..................................................................... 84

16. Estimated values, coefficients of variation, and the 95-percent linear confidence intervals for the parameters of the final calibrated model, and the range of reasonable values, with the range of reasonable values

17. Water budget for the final simulation compared with estimates from this study ................................................ 112

18. Total flow (including spring flow and evapotranspiration) at major discharge areas simulated with the final model and estimated for this study

\section{CONVERSION FACTORS AND VERTICAL DATUM}

\begin{tabular}{rll}
\hline Multiply & By & To obtain \\
\hline millimeter $(\mathrm{mm})$ & 0.03937 & inch \\
meter $(\mathrm{m})$ & 3.281 & foot \\
kilometer $(\mathrm{km})$ & 0.6214 & mile \\
square kilometer $\left(\mathrm{km}^{2}\right)$ & 0.3861 & square mile \\
cubic meter $\left(\mathrm{m}^{3}\right)$ & 35.31 & cubic foot \\
cubic meter $\left(\mathrm{m}^{3}\right)$ & 264.2 & gallon \\
cubic meter $\left(\mathrm{m}^{3}\right)$ & 0.0008107 & acre-foot \\
cubic meter per day $\left(\mathrm{m}^{3} / \mathrm{d}\right)$ & 0.1835 & gallon per minute \\
cubic meter per day $\left(\mathrm{m}^{3} / \mathrm{d}\right)$ & 0.2961 & acre-foot per year \\
meter per day $\left(\mathrm{m}^{3} / \mathrm{d}\right)$ & 3.281 & feet per day \\
square meter per day $\left(\mathrm{m}^{2} / \mathrm{d}\right)$ & 10.7649 & square foot per day \\
\hline
\end{tabular}

Temperature in degrees Fahrenheit $\left({ }^{\circ} \mathrm{F}\right)$ may be converted to degrees Celsius $\left({ }^{\circ} \mathrm{C}\right)$ as follows:

$$
{ }^{\circ} \mathrm{C}=\left({ }^{\circ} \mathrm{F}-32\right) / 1.8
$$

Sea level: In this report, "sea level" refers to the National Geodetic Vertical Datum of 1929 (NGVD of 1929) - a geodetic datum derived from a general adjustment of the first-order level nets of both the United States and Canada, formerly called Sea Level Datum of 1929. 


\title{
Hydrogeologic Evaluation and Numerical Simulation of the Death Valley Regional Ground-Water Flow System, Nevada and California
}

\author{
By Frank A. D'Agnese, Claudia C. Faunt, A. Keith Turner, and Mary C. Hill
}

\section{Abstract}

Yucca Mountain is being studied as a potential site for a high-level radioactive waste repository. In cooperation with the U.S. Department of Energy, the U.S. Geological Survey is evaluating the geologic and hydrologic characteristics of the ground-water system. The study area covers approximately 100,000 square kilometers between lat $35^{\circ} \mathrm{N}$., long $115^{\circ} \mathrm{W}$. and lat $38^{\circ} \mathrm{N}$., long $118^{\circ} \mathrm{W}$ and encompasses the Death Valley regional ground-water flow system.

Hydrology in the region is a result of both the arid climatic conditions and the complex geology. Ground-water flow generally can be described as dominated by interbasinal flow and may be conceptualized as having two main components: a series of relatively shallow and localized flow paths that are superimposed on deeper regional flow paths. A significant component of the regional ground-water flow is through a thick Paleozoic carbonate rock sequence. Throughout the regional flow system, ground-water flow is probably controlled by extensive and prevalent structural features that result from regional faulting and fracturing.

Hydrogeologic investigations over a large and hydrogeologically complex area impose severe demands on data management. This study utilized geographic information systems and geoscientific information systems to develop, store, manipulate, and analyze regional hydrogeologic data sets describing various components of the ground-water flow system.
A three-dimensional digital hydrogeologic framework model was developed utilizing digital elevation models, geologic maps and cross sections, and lithologic well logs. This framework model provides a description of the geometry, composition, and hydraulic properties of the materials that control the regional groundwater flow system. It also serves as an important information source for the development of the hydraulic properties of the numerical groundwater flow model.

In addition to the complex geology, a complex array of mechanisms account for flow into, through, and out of the regional groundwater flow system. Discharges from the regional ground-water flow system occur by evapotranspiration, springs, and pumpage. Evapotranspiration by plants and evaporative losses from playa surfaces account for the greatest volume of water discharged from the ground-water system. The Death Valley saltpan is the ultimate discharge area for this flow system, but other intermediate discharge areas account for significant water volumes. A map showing potential evapotranspiration areas was created by combining maps showing locations of selected vegetation classes, high-salinity soils, and locations of known springs.

In order to calculate recharge, the MaxeyEakin method was adapted to make it more sensitive to the critical factors believed to control recharge rates, by using data within the geoscientific information system to define altitude, slope and aspect, relative permeability, and vegetation. 
A new estimated regional potentiometric-surface map was constructed incorporating perennial marshes, springs, altitude, recharge areas, discharge areas, and ancillary hydrogeologic data sets to help determine water levels in data-poor areas.

The water budget for the Death Valley regional ground-water flow system is difficult to compute, because inflow and outflow volumes are poorly defined for many areas and because of the large size of this region. The ground-water budget indicates that outflows exceed inflows. The discrepancy is due to the uncertainties surrounding the estimation or assignment of volumes for ground-water pumpage and for evapotranspiration from the Death Valley saltpan.

The Death Valley regional ground-water flow system was simulated using a threedimensional steady-state simulation that incorporated a nonlinear least squares regression technique to estimate aquifer variables. The numerical modeling program MODFLOWP was used in creating a finite-difference model consisting of 163 rows, 153 columns, and three layers. The grid cells were oriented north-south and were of uniform size, with side dimensions of 1,500 meters. The layers span depth ranges of 0-500 meters, 500-1,250 meters, and 1,2502,750 meters below the estimated water table.

The required model parameter values were supplied by discretization of the threedimensional hydrogeologic framework model and digital representations of the remaining conceptual model components. The three-dimensional simulation supported the analysis of interactions between the relatively shallow local and subregional flow paths and the deeper dominant regional flow paths controlled by the carbonate aquifer.

During calibration of the model, techniques available in MODFLOWP allowed for estimation of a series of parameters that provided a best fit to observed hydraulic heads and flows. Numerous conceptual models were evaluated to test the validity of various interpretations about the flow system. Only those conceptual model changes contributing to a significant improvement in model fit, as indicated by a reduction in the sum of squared errors, were retained in the final optimized model. The final model was evaluated to assess the likely accuracy of simulated results by comparing measured and expected quantities with simulated values. Evaluation of the model indicates that the model is a reasonable representation of the physical system, but evidence of model error exists.

\section{INTRODUCTION}

A national, federally operated, mined-geologic, high-level nuclear waste repository is required to isolate spent nuclear fuel from energy facilities across the country. Yucca Mountain on and adjacent to the Nevada Test Site (NTS) in southwestern Nevada is being studied as a potential site for such a repository (fig. 1).

In cooperation with the U.S. Department of Energy (DOE), the U.S. Geological Survey (USGS) is evaluating the geologic and hydrologic characteristics of this site as part of the Yucca Mountain Project (YMP). Because of the potential for radionuclides to be transported by ground water from the repository to the accessible environment, ground-water flow-system dynamics must be characterized.

USGS evaluations include a detailed characterization of the ground-water flow system. As part of these hydrologic investigations, a regional threedimensional (3D) conceptual and numerical groundwater flow model has been developed to assist in the: (1) definition of boundaries of the subregional and local flow systems, (2) characterization of regional 3D ground-water flow paths, (3) definition of locations of regional ground-water discharges, (4) estimation of magnitudes and rates of regional subsurface flux, (5) assessment of potential effects of a pluvial climate on the regional flow system, (6) evaluation of potential and existing anthropogenic effects on ground-water flow, (7) characterization of potential impacts of the regional carbonate aquifer on subregional and local flow components, and (8) determination of potential effects of regional geologic structure on the flow system. While the final numerical ground-water flow model product of this study is not configured to conduct all of these simulations, it is an essential step toward meeting these goals. 


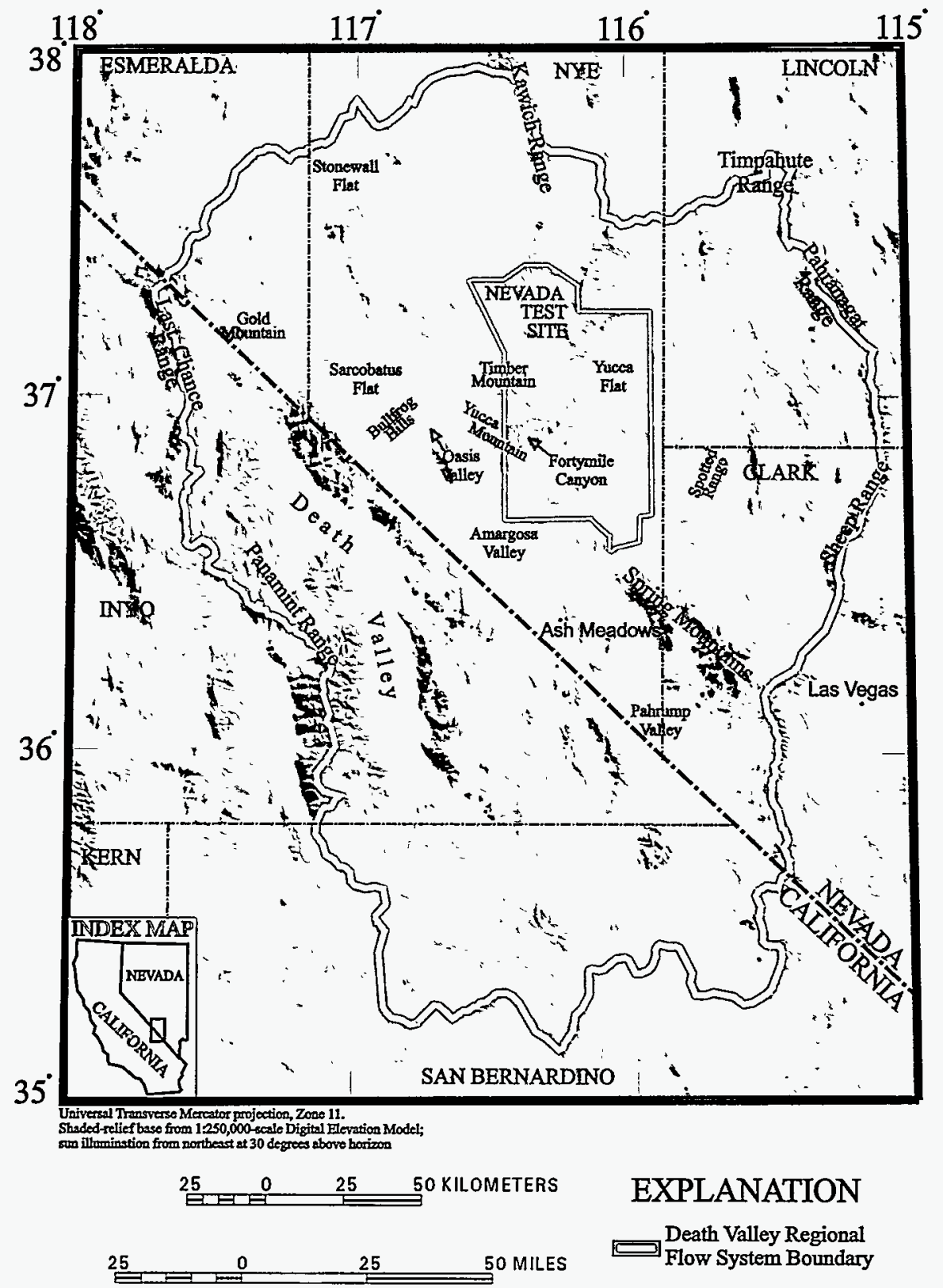

Figure 1. Geographic features of the Death Valley region. 


\section{Purpose and Scope}

The purpose of this report is to document the regional hydrologic modeling studies conducted by the USGS as part of the Yucca Mountain site characterization activities. This report characterizes the regional hydrogeology and documents a numerical simulation of the present-day ground-water flow system.

The data requirements for such an investigation are considerable. Large, spatial and temporal data sets, developed by numerous scientists from different disciplines, exist in various formats. Sophisticated computer-based information-management and datamodeling tools offer a feasible means of storing, manipulating, analyzing, and modeling these data for investigation purposes. The scope of this study can be summarized as follows:

1. The study is limited to the Death Valley region (fig. 1);

2. Details of the geology, structure, surface and ground-water hydrology, vegetation, soils, and climate were obtained from existing regional maps and data archives;

3. Existing data were used with only limited new field observations; and

4. Extensive analysis and synthesis were conducted using commercially available software, computer models, and analytical codes.

\section{Quality-Assurance Considerations}

Because interpretations of model results may be used to assess the expected performance of a highlevel, nuclear-waste repository, confidence in the reliability of data used in model construction and model evaluation is necessary. A quality-assurance program has been implemented by USGS for the YMP to support the reliability of the data and interpretations of data.

Data used by the YMP are classified as either "qualified" or "unqualified". Qualified data are defined as "data acquired or developed for the YMP under a Nuclear Regulatory Commission accepted quality assurance plan or qualified in accordance with appropriate YMP procedures. Developed data cannot be classified as "Qualified" if derived from unqualified data sources (U.S. Department of Energy, written commun., 1993).
Because of the regional scope of this report, data used in the construction of the hydrogeologic framework model and the ground-water flow model were developed from published sources or obtained from publicly available sources such as the USGS National Water Information System (NWIS). Nearly all of these sources originated or were published outside of the YMP, or were obtained and published before the implementation of the accepted YMP quality-assurance program in 1989. No qualified data, which are regional in scope, are available. Therefore, no data presented in this report can be classified as qualified, and conclusions drawn as a result of the modeling are based entirely on unqualified data. Model construction and review, however, were performed in accordance with accepted YMP qualityassurance procedures and USGS policy.

\section{Study Area}

The study area is bounded by $35^{\circ}$ and $38^{\circ} \mathrm{N}$. latitude and $115^{\circ}$ and $118^{\circ} \mathrm{W}$. longitude and was chosen to include the limits of the Death Valley regional ground-water basin, first defined by Bedinger and others (1989a). The Death Valley region is located along the border of southern Nevada and southeastern California (fig. 1). The area is immediately west of the city of Las Vegas, Nevada, and includes parts of Esmeralda, Nye, Lincoln, and Clark Counties, Nevada, and Inyo and San Bernardino Counties, California. Yucca Mountain is located in approximately the geographic center of the region, on the western border of the NTS (fig. 1).

\section{Previous Work in the Death Valley Region}

Geologic and hydrologic studies have been conducted intermittently in the region since the pioneering geologic investigations of Ball (1907) and initial hydrologic studies by Mendenhall (1909), Carpenter (1915), and Meinzer (1917) early in this century. Many geologic and hydrologic studies were undertaken after 1950 with support of the U.S. Atomic Energy Commission and, later, the DOE nuclear testing program. More recently, the potential for a nuclear waste repository at Yucca Mountain has resulted in additional regional and site-specific investigations. 


\section{Geologic and Structural Investigations}

Analysis of the regional hydrogeology of the Death Valley region required compilation and synthesis of geologic and structural data from several sources. A single coherent representation of the subsurface geologic and structural framework was achieved by relying on three principal sources:

1. Geologic information for the California portion of the Death Valley region was obtained from four 1:250,000-scale geologic quadrangle maps (Kingman, Trona, Mariposa, and Death Valley map sheets) belonging to the Geologic Atlas of California (Jennings, 1961; Jennings and others, 1962; Strand, 1967; Streitz and Stinson, 1974);

2. Geologic information for the Nevada portion of the Death Valley region was extracted from a digital version (Turner and Bawiec, 1991) of the 1:500,000-scale Geologic Map of Nevada (Stewart and Carlson, 1978); and

3. Thirty-two regional cross sections developed by Grose (1983) and regional geologic interpretations developed by Grose and Smith (1984; 1989) were used to define the basic subsurface geologic structure.

More detailed geologic maps of specific quadrangles, at scales of $1: 24,000,1: 48,000$, or $1: 62,500$, have been completed throughout the study area. Several of these maps are accompanied by extensive interpretive reports, and were used to resolve details or uncertainties observed in the primary data sources.

\section{Hydrogeologic Investigations}

The Death Valley region lies within a hydrogeologic region known as the carbonate-rock province of the Great Basin (Prudic and others, 1993), which is characterized by thick sequences of carbonate rocks. These rocks form a generally deep regional aquifer of the flow system, which allows interbasin transfers of ground water from northern and eastern Nevada toward the south and west.

The deep regional interbasin component of the ground-water flow system was recognized by the earliest ground-water investigations (Mendenhall, 1909; Carpenter, 1915; Meinzer, 1917). After these initial studies, few additional ground-water investigations were undertaken in the Death Valley region until after World War II, when studies of selected basins began. The initial report based on these studies described conditions within the Las Vegas, Pahrump, and Indian Springs valleys northwest of Las Vegas (Maxey and Jameson, 1948). Eakin and others (1976) summarized the results of all these individual basin studies.

Detailed consideration of the role of interbasin ground-water flow began in the 1960's. On the basis of geochemical analyses of spring and well waters, Hunt and Robinson (1960) first suggested the possibility of interbasin ground-water flow into Death Valley. Loeltz (1960) evaluated the source of water for the Ash Meadows springs in the Amargosa Desert and concluded that these springs were fed by water from the regional carbonate aquifer. Winograd (1962) discussed interbasin movement of ground water on the NTS. An assessment of ground-water conditions between Las Vegas and the Amargosa Desert (Winograd, 1962) presented evidence for fault controls on aquifers in the area. Several other studies in eastern and southern Nevada reinforced the importance of interbasin ground-water flow (Eakin and Moore, 1964; Eakin and Winograd, 1965; Eakin, 1966). These studies, together with ground-water studies in the Amargosa Desert (Winograd, 1971; Naff, 1973), revealed the importance of interbasin ground-water flow in southern Nevada (Naff and others, 1974).

Hydrogeologic assessments for southern Nevada and nearby regions were reported by Eakin and others (1963) and Maxey (1968). More detailed evaluations of the carbonate aquifers in the region were completed by Maxey and Mifflin (1966), Grove and others (1969), Winograd and Thordarson (1975), Winograd and Pearson (1976), and Mifflin and Hess (1979). Dettinger (1989) summarized the understanding of the regional carbonate aquifer up to 1989. The central portions of the Death Valley region include the southwest Nevada volcanic field (SWNVF), an extensive volcanic region composed of several partly overlapping caldera complexes. Blankennagel and Weir (1973) reported on the geohydrology of these volcanic rocks. A series of hydrochemical studies were undertaken to further define regional flow systems in both volcanic and carbonate rocks (Winograd and Friedman, 1972; Winograd and Thordarson, 1975; Winograd and Pearson, 1976; Claassen, 1983; Winograd and others, 1985; Winograd and Szabo, 1988; Thomas and Hoffman, 1988; Kirk and Campana, 1990; Thomas and others, 1990). 
More detailed hydrogeologic studies have been conducted for specific areas within the Death Valley region. Ground-water systems in Death Valley were investigated and described by Hunt and Robinson (1960), Pistrang and Kunkel (1964), Hunt and others (1966), and Miller (1977). The Ash Meadows hydrogeology has been described by Loeltz (1960), Dudley and Larson (1976), and Galloway (1993). Ground-water conditions within the Amargosa Desert were investigated by Walker and Eakin (1963), Winograd (1971), Naff (1973), and Czarnecki (1990). Other detailed hydrogeologic investigations of relevance to this study were conducted in the Sarcobatus Flat and Oasis Valley region by Malmberg and Eakin (1962), in the White River area by Eakin (1966), and in Owens Valley by Hollett and others (1991).

Detailed hydrogeologic studies within the NTS began in 1957 and the results of these studies were presented in numerous reports (Clebsch and Barker, 1960; Moore, 1961; Winograd, 1962; Thordarson and others, 1967; Rush, 1970; Thordarson and Robinson, 1971; Blankennagel and Weir, 1973). Winograd and Thordarson (1975) summarized most of the work from the 1957-64 period. Waddell (1984), Waddell and others (1984), and Robison (1984) reported on the results of subsequent investigations. Hydrogeologic data collected from water wells and exploratory drill holes at the NTS were reported by Bentley and others (1983), Bentley (1984), Thordarson (1983), Thordarson and others (1984), Craig and others (1983), Craig and Johnson (1984), Craig and Robison (1984), Lobmeyer and others (1983), Rush and others (1983; 1984), Lahoud and others (1984), Whitfield and others $(1984 ; 1985)$, and Waddell and others (1984).

Comprehensive maps and synthesis reports describing the regional ground-water flow systems were developed by Thomas and others (1986), Harrill and others (1988), Plume and Carlton (1988), and Bedinger and others (1989a; 1989b; 1989c). The most recent conceptual evaluation and synthesis of available data concerning these regional ground-water flow systems were conducted as part of the USGS Great Basin Regional Aquifer System Analysis (RASA) project (Prudic and others, 1993).

\section{Previous Ground-Water Models of the Death Valley Region}

The Yucca Mountain project has supported the construction of several ground-water flow models to evaluate the Death Valley regional ground-water flow system. Conceptual and numerical modeling has been undertaken by Oberlander (1979), Waddell (1982), Czarnecki and Waddell (1984), Rice (1984), and Sinton (1987). Each of these studies attempted to model the complex 3D hydrology and hydrogeologic framework, but these initial models involved great simplifications of the natural heterogeneity exhibited by the flow systems. Truly 3D flow modeling was impractical at the time because the methods for representing the complex hydrogeologic framework were not available. With each new modeling exercise, investigators further developed their understanding of the 3D nature of the Death Valley ground-water flow system.

Waddell (1982) used a two-dimensional (2D), finite-element model to simulate the ground-water system of the NTS. Results from this study substantiated many of the conclusions developed by earlier conceptual models. Waddell noted several model shortcomings:

1. The simulation was inaccurate in the eastern Pahute Mesa area, possibly because of the limited amount of data available for the east and northeast portions the NTS;

2. Structural controls of ground-water flow were poorly represented;

3. Vertical flow components were ignored; and

4. Estimation of transmissivity values from potentiometric data contained large uncertainties.

Czarnecki and Waddell (1984) used a finite-

element model to evaluate a sub-regional groundwater flow system in the Amargosa Desert. The model simulated 2D, steady-state ground-water flow conditions. Parameter-estimation techniques, using a non-linear regression model, were applied to head and flux data from various sources to estimate transmissivities within this flow system. Numerous simplifications were required to describe the flow system. The simulation poorly represented observed head values in areas where ground-water flow conditions violated assumptions of two-dimensionality, especially where vertical-flow components and steep hydraulic gradients occurred (Czarnecki and Waddell, 1984). 
These limitations were considered negligible because the majority of the flow was assumed to be horizontal.

Rice (1984) developed a preliminary, 2D, regional ground-water flow model of the NTS and vicinity. The model had a very similar approach to the model of Czarnecki and Waddell (1984). Rice's model contained detailed recharge and discharge estimations, but ignored the 3D heterogeneity characteristic of the region. Because the model was developed primarily to determine flux, Rice believed that using transmissivity values eliminated the need for detailed hydrogeologic framework characterization. This $2 \mathrm{D}$ modeling approach prevented accurate simulation of vertical movement of ground water in Pahute Mesa and resulted in calibration problems (Rice, 1984). Rice recommended that a 3D model be constructed to rectify this problem.

Sinton (1987) characterized the regional ground-water flow system for the NTS, essentially the same area modeled by Waddell (1982). Sinton's model was more sophisticated because it used a quasi3D, steady-state, finite-difference approach. The model included two transmissive layers. The upper layer represented a shallow aquifer composed of volcanic, basin-fill, and carbonate rocks and sediments. The lower layer represented a deep aquifer composed of carbonate and volcanic rocks. Horizontal flow was allowed within the aquifer layers and vertical flow was simulated and controlled between the layers by using a transmissive leaky unit (Sinton, 1987). The model demonstrated that the primary controls on ground-water flow are: (1) the spatial distribution of hydrogeologic units of small permeability, and (2) the distribution and magnitude of discharge and recharge locations (Sinton, 1987). Furthermore, the model simulations indicated that complex ground-water flow patterns may exist in the area. In the model these patterns were reflected by interactions between recharge or discharge rates and the transmissivities of the upper and lower model layers. Sinton conducted model sensitivity analyses and found that the rates of discharge and recharge appeared to be key components that controlled the accuracy of the simulation. Small adjustments in recharge or discharge rates often produced substantial changes in the simulated magnitude and direction of ground-water flow. As a consequence, Sinton recommended that the following aspects be investigated further:
1. The interaction between the lower carbonate aquifer and the overlying volcanic units;

2. The discharge rates at Ash Meadows, Death Valley, Alkali Flat, and other areas; and

3. The potential for recharge along Fortymile Wash and Fortymile Canyon.

\section{SITE DESCRIPTION}

The Death Valley region (fig. 2) includes several large prominent valleys: Amargosa Valley, Pahrump Valley, and Death Valley. The region also includes several major mountain ranges including the Panamint Range, the Spring Mountains, the Sheep Range, the Amargosa Range, the Kawich Range, the Kingston Range, the Pahranagat Range, the Timpahute Range, and the Last Chance Range. These major physiographic and geologic features result in a complex ground-water flow system.

\section{Physiography}

The Death Valley region is situated within the southern Great Basin, a subprovince of the Basin and Range physiographic province (Fenneman, 1931). Late Cenozoic activity and faulting accounts for much of the topographic relief (Grose and Smith, 1989). Altitudes range from $86 \mathrm{~m}$ below sea level at Death Valley to $3,600 \mathrm{~m}$ above sea level at Mount Charleston in the Spring Mountains. The relief between valleys and adjoining mountains locally exceeds $1,500 \mathrm{~m}$ (Bedinger and others, 1989a). Most of the principal mountain ranges have distinct northwest-southeast (NW/SE) trends, although the trends of intermediatescale topographic features are quite variable. The ranges occupy only about 25 percent of the landscape in the study area (Peterson, 1981). The remainder of the landscape is occupied by broad intermontane basins formed from tectonically down-dropped grabens. The basins are filled with alluvium and some interbedded volcanic deposits that gently slopes from the valley floors to the bordering mountain ranges forming piedmonts (Peterson, 1981).

The valley bottoms are local depositional centers, usually containing playa lakes that act as catchments for surface-water runoff (Grose and Smith, 1989). The Amargosa River (fig. 2), an intermittent stream whose drainage basin encompasses about 


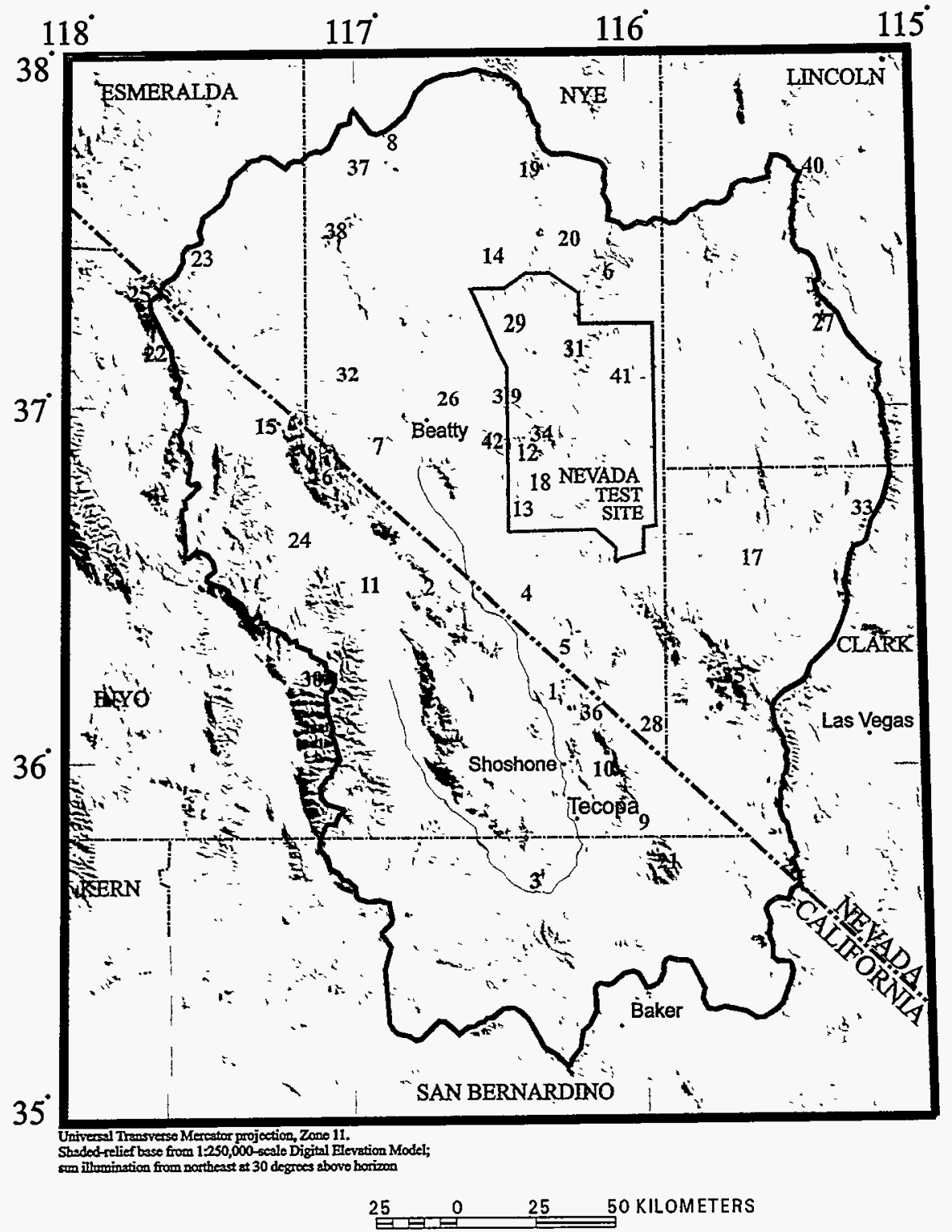

LOCATION KEY

1. Alkali Flat

2. Amargosa Range

3. Amargosa River

4. Amargosa Valley

5. Ash Meadows

6. Belted Range

7. Bullfrog Hills

8. Cactus Range

9. California Valley

10. Chicago Valley

11. Death Valley

12. Fortymile Canyon

13. Fortymile Wash

14. Gold Flat

15. Grapevine Canyon

16. Grapevine Mountains

17. Indian Springs

18. Jackass Flats

19. Kawich Range

20. Kawich Valley

21. Kingston Range

22. Last Chance Range

23. Magruder Mountain

24. Mesquite Flat

25. Montezuma Range

26. Oasis Valley

27. Pahranagat Range

28. Pahrump Valley

29. Pahute Mesa

30. Panamint Range

31. Rainier Mesa

32. Sarcobatus Flat

33. Sheep Range

34. Shoshone Mountain

35. Spring Mountains

36. Stewart Valley

37. Stonewall Flat

38. Stonewall Mountain

39. Timber Mountain

40. Timpahute Range

41. Yucca Flat

42. Yucca Mountain

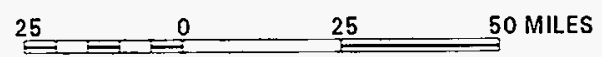

Figure 2. Prominent topographic features of the Death Valley region. 
$15,000 \mathrm{~km}^{2}$, discharges into the south end of the Death Valley salt pan, the largest of these playa lakes (Hunt and others, 1966). Most of the basins seldom contain perennial surface water. Playas and alluvial flats lying within these basins constitute about 10 percent of the region (Bedinger and others, 1989a). Numerous playas contain saline deposits that indicate the evaporation of surface water and/or shallow ground water from the playa surface. Some of the playas that have been deformed by Quaternary faulting contain springs where ground water is forced to the surface by juxtaposed lake sediments and alluvial aquifers (Bedinger and others, 1989a).

\section{Climate}

Climatic conditions in the Death Valley region are controlled by both altitude and latitude. The northern part of the region, including the Cactus,
Kawich, and Timpahute Ranges (fig. 2), forms part of the Great Basin Desert which is characterized by warm, dry summers and cold, dry winters. The southern part of the region, including Death Valley and the Eastern Mojave, forms part of the Mojavean Desert which is characterized by hot, dry summers and warm, dry winters (Benson and Darrow, 1981). The central region around the NTS has been called the Transition Desert (Beatley, 1976) which represents a mixing of the two climates (fig. 3).

\section{Precipitation}

Precipitation in the region is influenced by two distinct storm patterns affecting the desert climate; one in the winter, the other in summer. Winter precipitation (dominantly snow) tends to be of low intensity and long duration, and covers large areas. In contrast, most summer rains result from localized convective

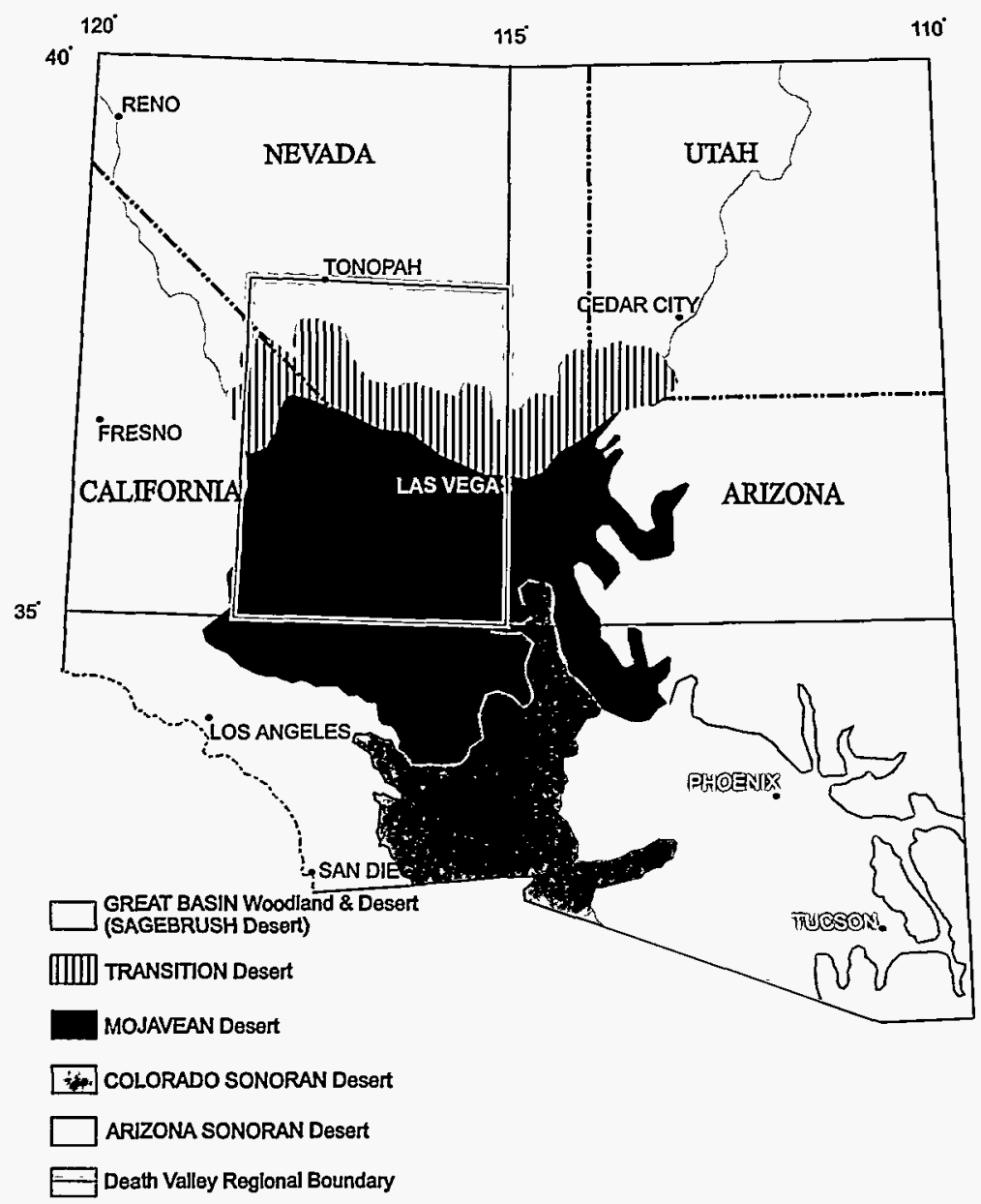

Figure 3. Desert climatic zones of the Death Valley region (modified from Benson and Darrow, 1981). 
thunderstorms of high intensity and short duration (Hales, 1972; 1974).

Quiring (1965) and French (1983) analyzed the distribution of precipitation resulting from the winter and summer weather regimes across southern Nevada. Quiring (1965) concluded that two sources (one winter and one summer) of precipitation can be identified (fig. 4). Precipitation resulting from these moisture sources, which affect regions south of 38.5 degrees north latitude, is influenced by major orographic and topographic controls. As a consequence, some areas of southern Nevada receive a relative excess of precipitation while other areas receive a relative deficit (French, 1983).

Both Quiring (1965) and French (1986) documented the moisture source pattern by regressing the logarithm of normalized annual precipitation versus altitude, using observations from weather stations in southern Nevada. The linear regression for all stations exhibited a poor fit. Grouping of stations above and below the regression line, however, indicated that the use of three regression lines, based on an areal separation of stations, for deficit, transition, and excess zones are required for a better fit (Rice, 1984). Using these regressions, investigators can develop a generalized description of average annual precipitation for the region.

The above interpretations agree relatively well with observed measurements. A relative abundance of precipitation falls in the mountains, exceeding $700 \mathrm{~mm} / \mathrm{yr}$ in the Spring Mountains; however, a moisture deficit is found in the valley bottoms, where precipitation can average less than $50 \mathrm{~mm}$ per year in areas such as Death Valley (Winograd and Thordarson, 1975).

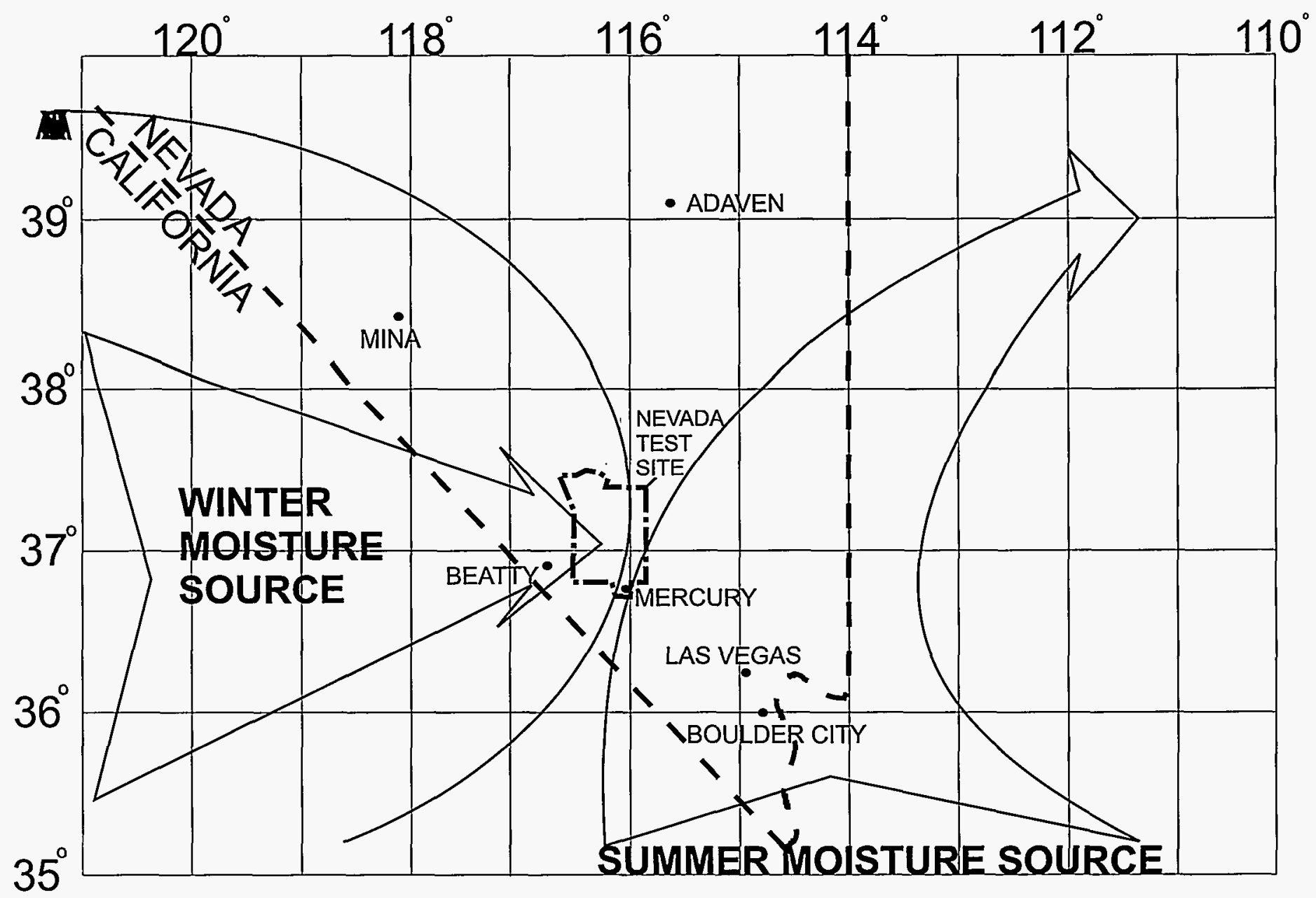

Figure 4. Weather regimes of the Death Valley region (modified from French, 1983). 
Hevesi (U.S. Geological Survey, written commun., 1990) combined regularly sampled digital elevation data and weather station precipitation data, using the geostatistical method of cokriging, and developed improved average annual precipitation distributions for the upper Armagosa River drainage basin. The same techniques were used to estimate average annual precipitation over the entire Death Valley region, based on available precipitation and altitude data (J. Hevesi, U.S. Geological Survey, written commun., 1995).

\section{Air Temperature and Humidity}

Average annual air temperature in the region ranges from about $5^{\circ} \mathrm{C}$ in some of the high northern valleys to about $16^{\circ} \mathrm{C}$ in the extreme southwestern valleys (Eakin and others, 1976). Especially characteristic of the regional climate is the wide range between daily maximum and minimum temperatures. The daily range exceeds $17^{\circ} \mathrm{C}$ in most valleys and reaches $28^{\circ} \mathrm{C}$ in some valleys in western Nevada (Eakin and others, 1976).

Average annual humidity ranges between 30 and 40 percent over most of the region, but is only about 20 percent in the southern part of the region (Eakin and others, 1976). Humidity in Death Valley at National Park Service Headquarters averages between 10 and 25 percent (Hunt and others, 1966). The low humidity, coupled with abundant sunshine and light to moderate winds, produces very rapid evaporation. Average annual lake-evaporation values range from about $1,100 \mathrm{~mm}$ in the north to more than $3,000 \mathrm{~mm}$ in Death Valley (Kohler and others, 1959).

\section{Soils and Vegetation}

The soils and vegetation of the Death Valley region are controlled to a significant degree by climatic, geomorphic, and hydrologic factors. These relations are highly variable and complex.

\section{Soils}

Soils in the Death Valley region typically follow a pattern of lithosols on the mountains, medium- to coarse-textured soils on alluvial fans and terraces, and fine-grained, alluvial soils in the valley bottoms. In general, the soils of the mountains and hills are shallow and exhibit a coarse texture with little moisture-holding capacity. The soils of the alluvial fans on the upper bajadas are also coarse textured, but are much deeper, so infiltration rates are relatively high. Infiltration rates of the alluvial basin soils are slow because the downward movement of water is often impeded by indurated calcium carbonate layers (pedogenic carbonate), fine-grained playa deposits, and, more infrequently, by silicified hardpans that form within the soils over time (Beatley, 1976).

\section{Vegetation}

The desert flora of the Death Valley region contain some of the most intricate plant communities in North America. Because these vegetation types are infiuenced by so many factors, only general descriptions of plant distributions are feasible. Nine vegetation communities in the region are described as homogeneous units, although their natural distributions are often heterogeneous with variable species densities (Munz, 1974). The distribution of these communities are shown on figure 5 .

Water availability and temperature control plant occurrence. Climate is the primary factor, and it reflects both latitude and altitude. Thus, vegetation communities in the region demonstrate both topographic and geographic patterns. Mixing of the cold, northern Great Basin Desert climate with the warm, southern Mojave Desert climate results in a heterogeneous distribution of plant associations, rather than distinct homogenous associations (Beatley, 1976).

Within a given climatic zone, the plant distribution closely reflects the local water availability (West, 1989). Geologic conditions, including the mineralogy and texture of the near surface soil materials, partially control the quantity and quality of the water, and the plants reflect these differences. The differences are especially important in desert regions. Where ground water is shallow enough to be within reach of the plant roots, plants will utilize water from below the water table, or at least from within the capillary fringe, and thus be assured of a perennial water supply. Such plants were first defined as phreatophytes by Meinzer (1923). Because different species of phreatophytes have different rooting depths, their presence or absence is a good indicator of depth to water (Robinson, 1958). Where the depth to the water table is greater than root depth, plants must rely on the moisture supplied by the rare precipitation events, and 


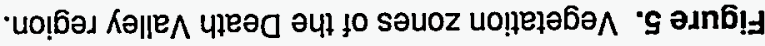

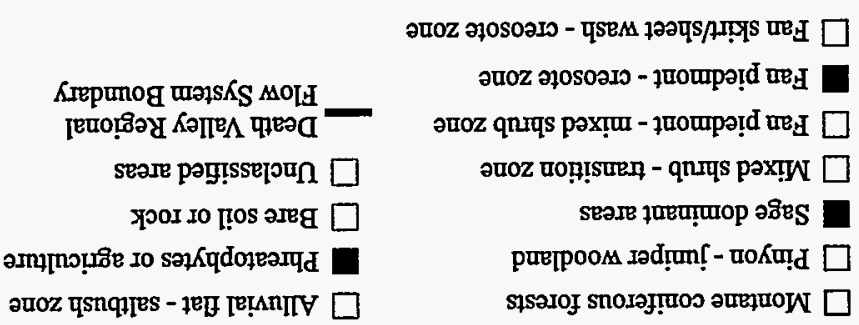

\section{NOILFNVTdXG}

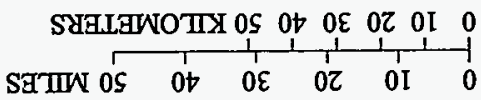

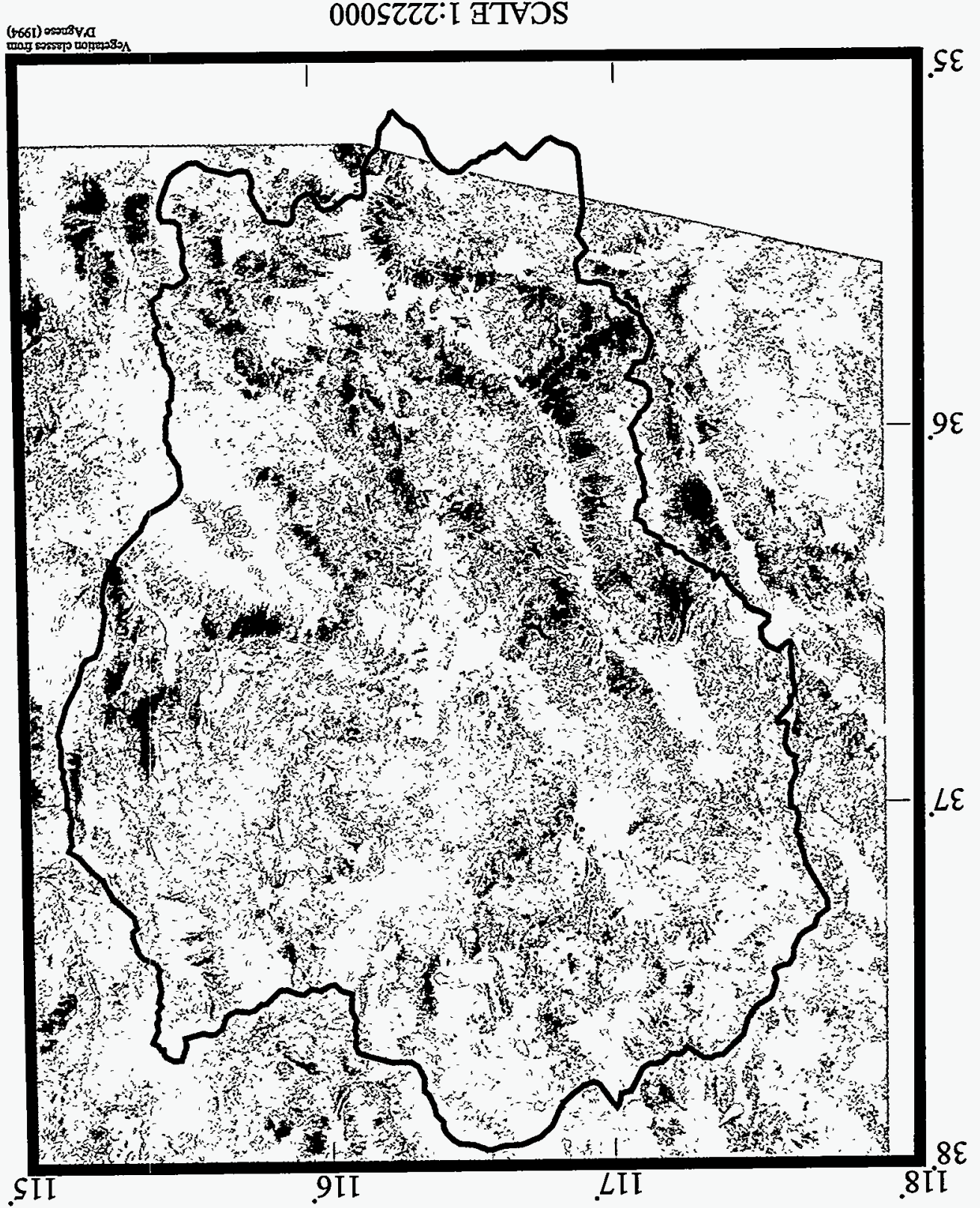


during prolonged drought they must maintain themselves in a nearly dormant condition. These plants are known as xerophytes (Meinzer, 1923). Only certain species can extract the needed moisture from more fine-grained materials.

Soil chemistry, especially the presence or absence of saline conditions, also affects the distribution of plants. Salt-tolerant species have adapted so that they may flourish in highly alkaline soils by concentrating salt materials in their leaves. Therefore, these species can be found growing in areas where poor drainage and high evaporation yield high salt concentrations (Hunt, 1966).

\section{Geology}

The Death Valley region has a long and active geologic history, including intermittent marine and non-marine sedimentation, large-scale compressive deformation, plutonism, volcanism, and extensional tectonics (Stewart, 1980; Mifflin, 1988).

Consequently, diverse rock types, ages, and deformational structures are often juxtaposed to each other. As a result, subsurface conditions are variable and complex. Knowledge of the geologic diversity beneath alluvial basins is indirect in most of the region.

The Death Valley region consists of Precambrian and Cambrian clastic and crystalline rocks; Paleozoic clastic and carbonate rocks; clastic and intrusive rocks of Mesozoic age; varied fluvial, paludal, and playa sedimentary deposits of Pliocene age; volcanic rocks and alluvium; and Tertiary alluvium and colluvium, and eolian deposits of Quaternary age (Waddell, 1982). The region has been altered by several episodes of tectonic activity. Structural and tectonic features of the study area (fig. 6) reveal a long, complex, tectonic evolution. Literature on specialized studies is voluminous; yet only a few integrative, comprehensive, and summary papers exist (Grose and Smith, 1989). Burchfiel and Davis (1981) discussed tectonic regimes in the California area, and Stewart (1978) discussed the tectonics of the Nevada part of the region concisely and comprehensively using structural mechanics principles. Grose and Smith (1989) describe this geologic complexity and offer insight into the hydrogeologic and tectonic controls on ground-water flow. Most of the study area has undergone deforma- tion, and some parts have been nearly continuously tectonically active (Grose and Smith, 1989). The structural features and faulting are a result of the complex interaction of the North American and Pacific plates (Smith and Sbar, 1974). Combinations of normal, reverse, and strike-slip faulting and folding episodes have resulted in complex distributions of rocks.

Metamorphic basement rocks of Precambrian age were deposited approximately 1.7 to 1.4 billion years ago in geosynclinal, orogenic, and magmatic arc-type terranes. Sedimentation patterns were also influenced by the northeast-southwest (NE/SW) trending Transcontinental arch. During the late Precambrian, the study area underwent a period of continental margin rifting (Grose and Smith, 1989).

From Late Precambrian to Devonian, continental quartzites and siltstones were deposited with an additional $8,000 \mathrm{~m}$ of carbonate and calcareous shales in a westward-thickening clastic and carbonate wedge sequence. The first major Phanerozoic tectonic event in the Death Valley region was the Antler orogeny. During the Antler orogeny (Devonian to Mississippian), a thick wedge of clastic rocks derived from adjacent highlands was deposited in a NE/SW trending basin. This basin now is defined by the location of the Eleana Formation, which contains dominantly relatively impermeable argillites and shales. The Antler orogeny also caused eastward thrusting of more than $100 \mathrm{~km}$ of deep-ocean shales, chert, and volcanic rocks. The leading edge of the Roberts Mountain thrust is in the northwestern part of the Death Valley region (Grose and Smith, 1989).

During the Carboniferous, after the Antler orogeny and before the Sonoma orogeny, rifting and compression occurred, creating localized basins. Various sedimentary rocks were deposited as interbeds in these basins within an otherwise uninterrupted deposition of carbonates. The Sonoma orogeny (late Permian and early Triassic) resulted in a period of deep-ocean siliceous rock and volcanic rock deposition, followed by overthrusting. Structures associated with the Sonoma orogeny occur mainly in the northwestern part of the Death Valley region (fig. 6). These events created scattered terranes of lower Mesozoic metasedimentary and metavolcanic rocks. The Sevier orogeny (middle Jurassic and late Cretaceous) was highlighted by north-south-trending thrust faulting (including the Pahranagat, Gass Peak, Lee Canyon, and Keystone thrusts within this study 


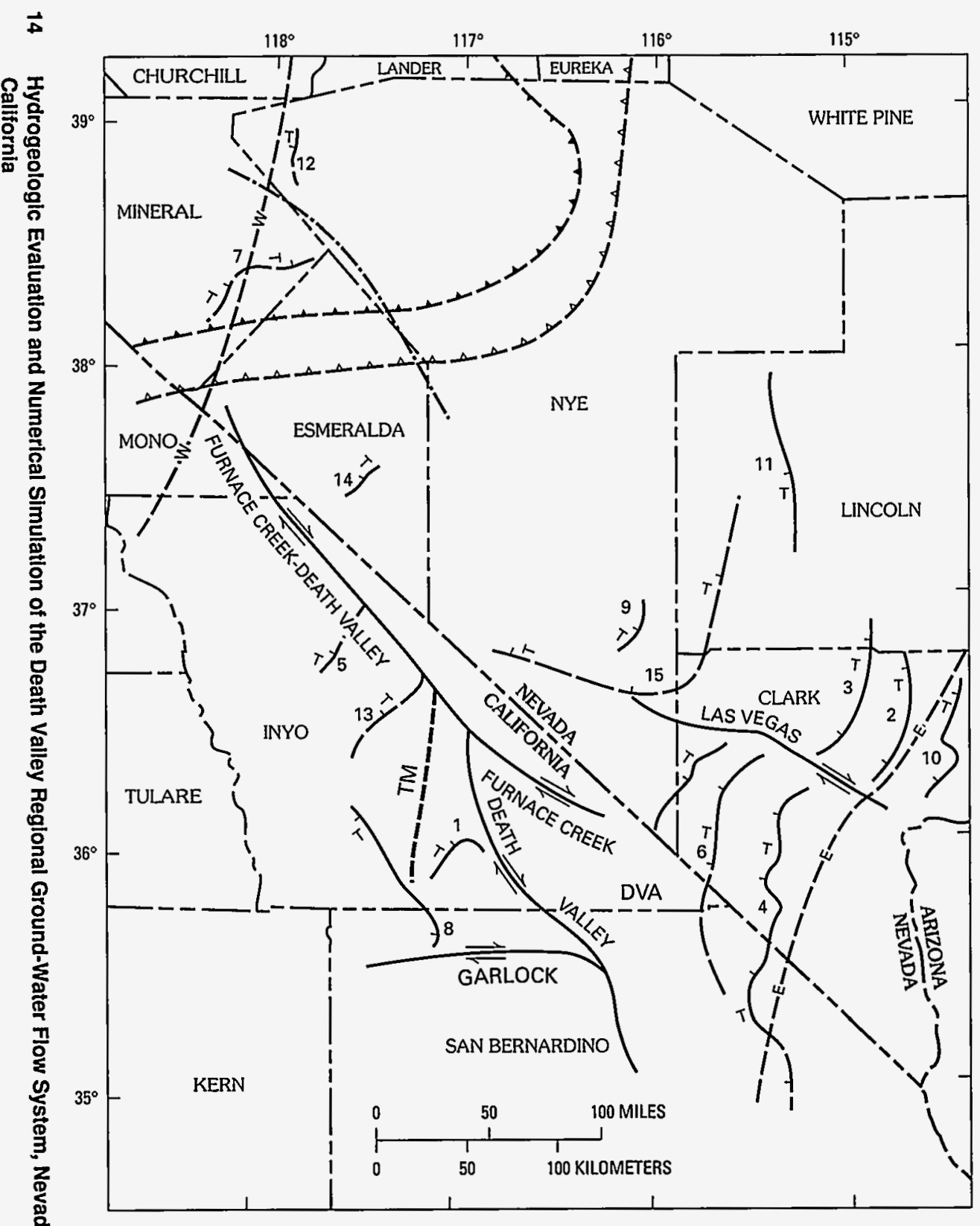

\section{EXPLANATION}

--E- - EAST LIMIT OF MIOGEOSYNCLINAL SHELF; WEST LIMIT OF CRATONAL PLATFORM-Late Precambrian to Late Cretaceous

—.W- - WEST LIMIT OF MIOGEOSYNCLINAL SHELF; WEST LIMIT OF GRANITIC ROCKS OF CONTINENTAL. CRATON-Early and Middle Proterozoic

$\Lambda ـ \Lambda$ ROBERTS MOUNTAIN THRUST FAULT(LEADING EDGE) OF ANTLER OROGENY - Late Devonian to Early Mississippian. Sawteeth on upper plate

ㄴ. GOLCONDA THRUST FAULT (LEADING EDGE) OF SONOMA OROGENY - Late Permian to Early Triassic. Sawteeth on upper plate

$10, T$ MAJOR THRUST FAULTS OF SEVIER OROGENY, CRETA CEOUS , AND OLDER UNNAMED THRUSTING EVENTS $\begin{array}{lll}1 & \text { Butte Valley } & 9 \\ 2 & \text { Dry Lake } & 10 \text { Muddy Mountain-Glendale }\end{array}$

3 Gass Peak 11 Pahranagat Range

4 Keystone 12 Paradise

5 Last Chance 13 Racetrack

6 Lee Canyon 14 Silver Peak

7 Luning $\quad 15$ Spotted Range

8 Leyton Weil

$\rightleftharpoons$ MAJOR STRIKE-SLIP FAULTS-Cenozoic. Arrows indicate direction of relative movement

- TM - SHEAR ZONE-TM, Towne Pass-Manly Pass

NORTHEAST MARGIN OF WALKER LANE WHERE RELATIVELY WELL DEFINED

DVA DEATH VAILEY AULACOGEN AREA-Late Precambrian

Figure 6. Tectonic features of the Death Valley region and vicinity (modified from Bedinger and others, 1989a). 
area) and simultaneous intrusions of granites of Mesozoic age throughout the Death Valley region (Grose and Smith, 1989) (fig. 6).

In contrast to earlier compressional tectonism, regional uplift, erosion, volcanism, and extension occurred in the Tertiary. As a result, the Death Valley region now includes numerous north-south-trending valleys containing continental alluvial, paludal, and colluvial materials that are interstratified with volcanic lava flows, tuffs, and tuffaceous sediments. The study area also underwent a period of intense volcanism during the late Tertiary and was heavily scarred by massive volcano-tectonic and caldera depressions and voluminous ash flows. Meanwhile, water levels in pluvial lakes rose and fell in response to climate fluctuations, and deposition of basin-fill materials continued.

Superimposed on the earlier structural features, and dominating the topographic and physiographic features of the study area, is a basin and range type of deformation and associated volcanism (Grose and Smith, 1989). According to Dickinson and Snyder (1979), basin and range deformation occurred in two phases. The first phase began during late Eocene and ended during middle Miocene and is associated with the deposition of silicic volcanic rocks. The second phase of extensional tectonics was characterized by reduced volcanic activity and was important in shaping present-day topography. Late Cenozoic tilting and warping also is evident (Grose and Smith, 1989). Tectonic activity in the Basin and Range Province has continued to historic times, as indicated by historic faulting in the study area. Carr (1982) suggests that basin and range deformation has decreased in the last few million years because the amount of offset along normal faults decreases nearer the surface.

The basin and range tectonics is superimposed on the Walker Lane Belt (fig. 7), a NW/SE trending, right-lateral, strike-slip shear zone located near the southern Nevada-California border (Lock and others, 1940; Longwell, 1960; Stewart, 1971, 1978). The Walker Lane Belt is part of a megastructure that crosses the Basin and Range Province from Texas to Oregon (Carr, 1990). The Walker Lane Belt separates the NW/SE structural-physiographic trends in the southwestern Great Basin, east of the Sierra Nevada, from the predominantly north-south trend of the more typical basin and range structure. The belt has long been recognized as an area of active faulting containing patterns of faults that are anomalous with respect to the typical fault patterns in the Great Basin (Reheis, 1990). The belt is dominated by lateral rather than dip-slip faulting, and except for caldera structures, large vertical displacements are not characteristic (Carr, 1990). The Las Vegas Valley shear zone and the Furnace Creek-Death Valley fault system (fig. 6) are major structural features associated with the Walker Lane belt.

Within the study area, the southern Great Basin has diverse structural trends, styles, and tectonic activity (Carr, 1988). Carr (1990) divided the area into four major structural-physiographic subsections: classic Basin and Range, Walker Lane, Inyo-Mono, and undifferentiated southern Great Basin (fig. 7). Within these subsections are two NE/SW trending structural zones: the Spotted Range-Mine Mountain zone and the Pahranagat shear zone (fig. 7). Winograd and Pearson (1976) refer to a NE/SW trending megascale channel influencing a major potentiometric trough. The location of the trough is probably structurally controlled (Winograd and Thordarson, 1975 , p. C71-C74) and is roughly coincident with a portion of the Spotted Range-Mine Mountain zone.

In addition to the Spotted Range-Mine Mountain and Pahranagat Shear zones, the Walker Lane belt also contains a number of somewhat lessdefined NE/SW trending structural zones. Because they contain highly fractured rocks with potentially large transmissivity, these less-defined zones may influence regional ground-water flow patterns (Faunt, 1994; Carr, 1984). These less-defined zones include: $\mathrm{NE} / \mathrm{SW}$ trending structural lineaments from the Bullfrog Hills across the Timber Mountain Caldera (fig. 7, a), a similar trend from southern Sarcobatus Flat to Black Mountain Caldera (fig. 7, b) and a NE/SW structural-topographic trend from Death Valley through the Gold Mountain-Slate Ridge area to Stonewall Flat (fig. 7, c).

Another major structural feature that may influence regional flow is the SWNVF. This region of prolonged Tertiary volcano-tectonic activity includes several caldera depressions and resurgent volcanic intrusions. These features may have altered the ground-water flow system by altering or completely removing the carbonate rocks that form the regional aquifer, thereby truncating portions of the deep component of the regional flow system (fig. 7). 


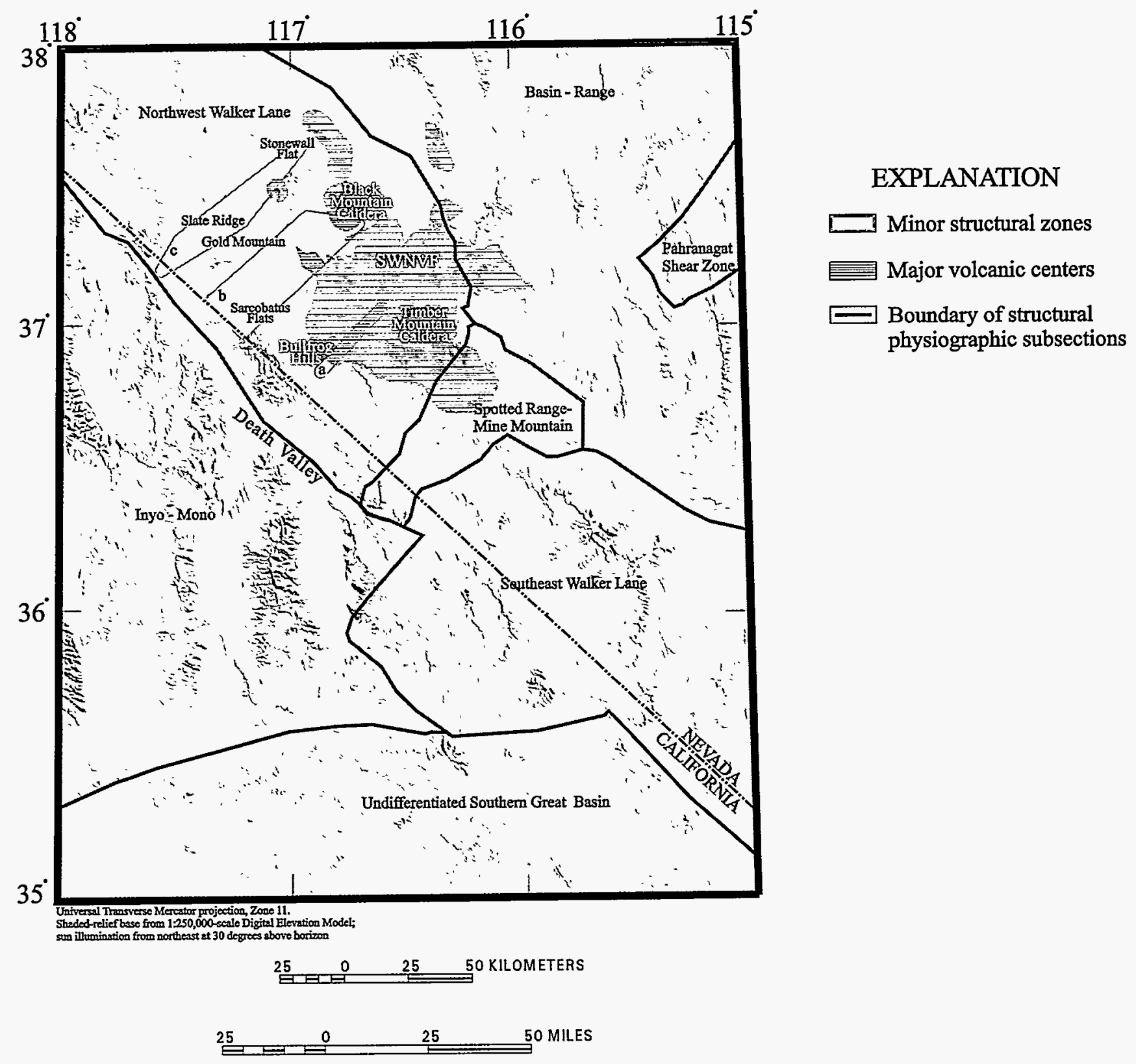

Figure 7. Structural-physiographic subsections (modified from Carr, 1990). Major volcanic centers are shaded (Carr, written commun., 1990). 


\section{Hydrogeologic Units}

In this report, the rocks and deposits forming the framework for a ground-water flow system are termed hydrogeologic units. A hydrogeologic unit has considerable lateral extent and has reasonably distinct hydrologic properties because of its physical (geological and structural) characteristics. The physical characteristics of the region were used to classify the rocks and deposits into hydrogeologic units. Although all the major geological features were retained, many of the smaller geologic units were grouped into larger entities by generalizing both lithologic and hydrologic properties of the bedrock geology units. Table 1 defines the ten hydrogeologic units of the Death Valley region, and figure 8 shows the spatial distribution of these units.

\section{Quaternary Playa Deposits}

Quaternary playa deposits are relatively homogeneous deposits composed of mainly sand, silt, and clay-sized particles (Denny and Drewes, 1965). The unit not only includes fine-grained playa deposits, but also lacustrine limestone and evaporites. Accordingly, the unit can exhibit matrix flow in the permeable unconsolidated deposits, and fault and fracturecontrolled flow in consolidated deposits (Downey and others, 1990). The playa deposits were deposited contemporaneously with the younger alluvial sediments. As a result, the deposits grade into each other. In some of the valleys, the unit is several hundred meters thick.

\section{Quaternary-Tertiary Valley Fill}

Quaternary-Tertiary valley fill is a heterogeneous mixture of fine-grained playa and lakebeds containing evaporites (of limited areal extent), fluvial deposits, heterogeneous debris flow and fan deposits, and volcanic tuffs (Bedinger and others, 1989a). Accordingly, the ground water flowing within these deposits may exhibit matrix flow as a result of the permeable unconsolidated materials, and fault- and fracture-controlled flow in consolidated deposits (Downey and others, 1990). The valley fill was accumulated largely in structural basins. As a result, the valley-fill deposits range in thickness from zero at margins of valleys to several hundred meters in valley lowlands. The fill in many basins is greater than $1,300 \mathrm{~m}$ thick and may be as thick as $2,000 \mathrm{~m}$ (Bedinger and others, 1989a). The valley fill forms the major aquifer system in many of the valleys.

Valley-fill aquifers constitute a regional system because of the similarities between basins and because they are the most developed source of ground water in the region. Well yields within the valley fill seem to be related to physiographic setting (Plume and Carlton, 1988). The hydrologic properties of these

Table 1. Estimated hydraulic conductivity of hydrogeologic units

[Sources: Waddell (1982), Bedinger and others (1989a, b)]

\begin{tabular}{|c|c|c|}
\hline Hydrogeologic unlt & Description & $\begin{array}{l}\text { Hydraulic conductivity } \\
\text { (meters/day) }\end{array}$ \\
\hline Quaternary playa deposits (Qp) & Lakebed deposits of silt and clay & $1 \times 10^{-5}$ to $2 \times 10^{-3}$ \\
\hline Quaternary-Tertiary valley fill (QTvf) & $\begin{array}{l}\text { Alluvial (stream channel and fan gravels), colluvial, } \\
\text { ash fall, and lake deposits }\end{array}$ & $1 \times 10^{0}$ to $7 \times 10^{+1}$ \\
\hline Quaternary-Tertiary lava flows (QTV) & Rhyolitic, andesitic, and basaltic lava flows & $5 \times 10^{-5}$ to $1 \times 10^{0}$ \\
\hline Tertiary volcanic rocks (Tv) & Dominantly rhyolitic ash flow tuffs & $5 \times 10^{-5}$ to $5 \times 10^{0}$ \\
\hline Tertiary volcanic and volcaniclastic rocks (Tvs) & Tuffs and tuffaceous clastic rocks & $5 \times 10^{-5}$ to $5 \times 10^{-3}$ \\
\hline Tertiary-Late Jurassic granitic rocks (TJg) & Crystalline granitic rocks & $2 \times 10^{-8}$ to $6 \times 10^{-1}$ \\
\hline Mesozoic sedimentary and metavolcanic rocks (Mvs) & Dominantly sandstones & $6 \times 10^{-3}$ to $4 \times 10^{-1}$ \\
\hline Paleozoic carbonate rocks (P2) & Limestones, dolomites, and calcareous shales & $7 \times 10^{-4}$ to $1 \times 10^{3}$ \\
\hline Paleozoic-Precambrian clastic rocks (PI) & Conglomerates, argillites and quartzites & $2 \times 10^{-8}$ to $6 \times 10^{-1}$ \\
\hline Precambrian metamorphic rocks (pGgm) & Crystalline rocks (gneisses, schists, and migmatites) & $2 \times 10^{-8}$ to $6 \times 10^{-1}$ \\
\hline
\end{tabular}




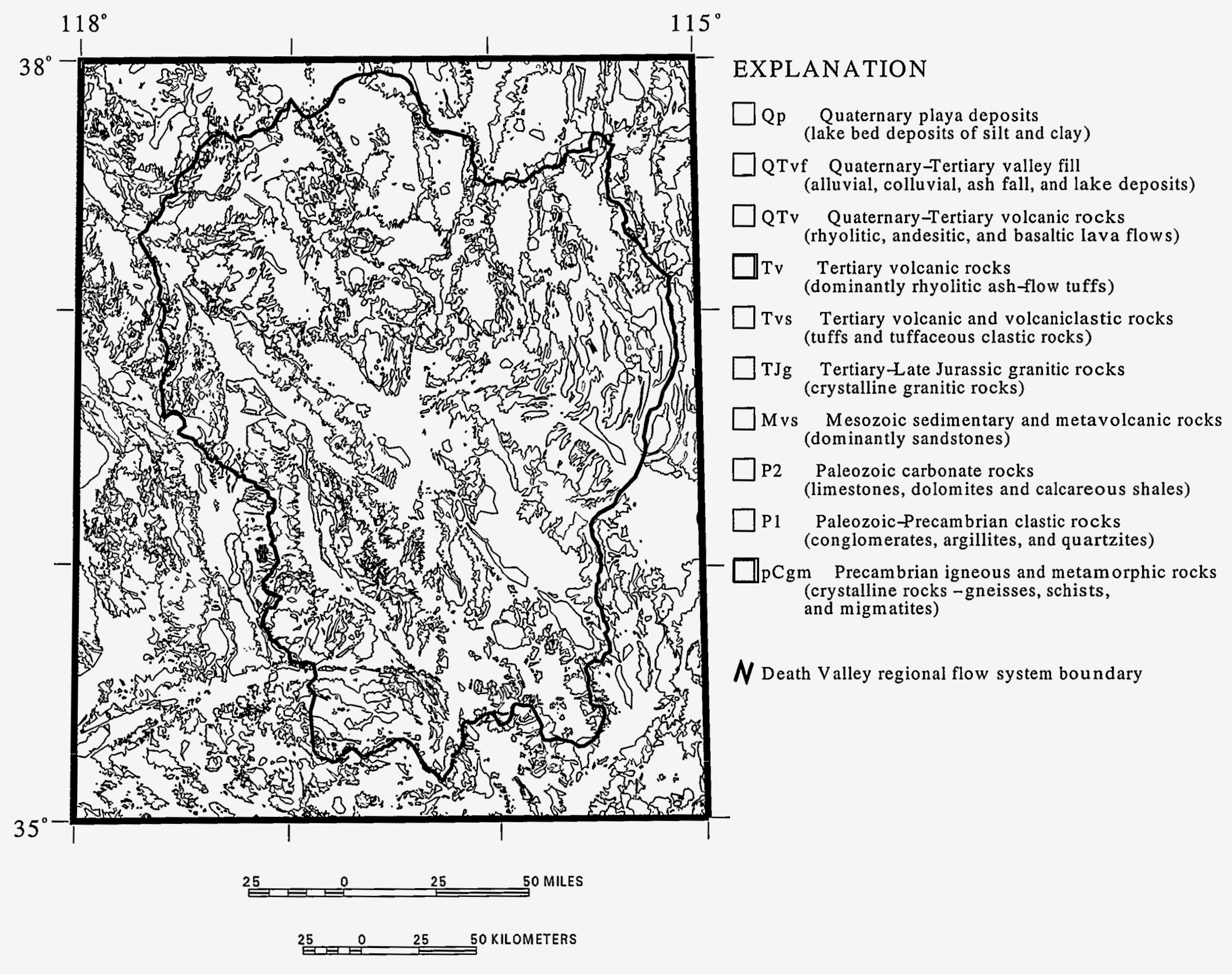

Figure 8. Hydrogeologic units of the Death Valley region. 
deposits can differ greatly over short distances, both laterally and vertically, because of abrupt changes in grain size and the degree of sorting and consolidation.

\section{Quaternary-Tertiary Volcanic Rocks}

The volcanic rocks, including lava flows and undifferentiated volcanic rocks of Tertiary and Quaternary age, underlie the valleys and crop out extensively in many of the mountains. The lava flows are primarily basalts, andesites, and rhyolites of Tertiary and Quaternary age. Columnar jointing and platy fractures are common in the flows, which vary from vesicular to dense (Bedinger and others 1989a, p. F28). Secondary openings are developed along fractures and bedding planes. Individual flows generally are less than $30 \mathrm{~m}$ thick, some are less than $1 \mathrm{~m}$ thick; however, aggregate thicknesses are as much as $1,000 \mathrm{~m}$ (Bedinger and others, 1989a, p. F28). Permeability and porosity is developed along fractures and bedding planes (Bedinger and others, 1989a, p. F28).

\section{Tertiary Volcanic Rocks}

Rhyolitic ash-flow tuffs and undifferentiated volcanic rocks of Tertiary age underlie the valleys and crop out extensively in northern and central portions of the area, including the Yucca Mountain area, where tuffs of Tertiary age are widespread (fig. 8). These units have an aggregate thickness of more than $4,000 \mathrm{~m}$ (Bedinger and others, 1989a). The composition and structure of these volcanic tablelands, and their position and mode of emplacement, drastically affect regional ground-water flow by altering flow paths, providing numerous avenues of recharge, and altering water-table gradients.

This hydrogeologic unit includes densely welded to nonwelded, bedded, reworked, and air-fall tuffs. Welded ash-flow tuffs characteristically have an interstitial porosity of about 5 percent or less (Bedinger and others, 1989a, p. F28); thus, the commonly moderate to large hydraulic conductivity of welded ash-flow tuffs is largely a function of secondary openings along joints, bedding planes, and partings within the flows. Where these welded tuffs are not fractured or jointed, they tend to form confining beds; thus, welded tuffs can only transmit significant quantities of water where they are fractured.
Nonwelded ash-flow tuffs may have a large interstitial porosity; however, they have low hydraulic conductivity, and function as confining beds. Fractures and joints are virtually absent in nonwelded ash-flow tuffs (I.J. Winograd, U.S. Geological Survey, written commun., 1971). These nonwelded tuffs, however, have limited areal extent.

\section{Tertiary Volcanic and Volcaniclastic Rocks}

This hydrogeologic unit is composed of tuffs and associated sedimentary rocks of Late Tertiary age. These rocks include up to $1,500 \mathrm{~m}$ of a variety of nonwelded to welded ash-flow tuff, ash-fall tuff, tuff breccia, breccia-fiow deposits, tuffaceous sandstone, siltstone, mudstone, freshwater limestone, and minor amounts of densely welded tuff. Despite the widely differing origins of these rocks, this unit usually has matrices consisting of zeolite or clay minerals (Winograd and Thordarson, 1975), which results in low hydraulic conductivity values. Some of the limestone and densely welded tuff may not have zeolitic or clayey matrices, but may also have a low hydraulic conductivity (Winograd and Thordarson, 1975). These rocks usually separate the more permeable volcanic rocks from the Paleozoic carbonate rocks.

\section{Tertiary-Late Jurassic Granitic Rocks}

Crystalline granitic rocks of Mesozoic and Tertiary age are widespread throughout the southern portion of the region. They crop out in many mountain ranges (fig. 8) and underlie most of the southern portion of the region at depth (Bedinger and others, 1989a). Ground water is thought to occur in these crystalline rocks only where they are fractured. Because the fractures are poorly connected, these rocks act mostly as confining units.

\section{Mesozoic Sedimentary and Metavolcanic Rocks}

The clastic rocks of Mesozoic age are predominantly continental fluvial, lacustrine, and eolian deposits and clastic and carbonate sedimentary rocks. These rocks form extensive outcrops on the sides of the Spring Mountains where they have been thrusted (fig. 8). The rocks have a variable thickness due to the extensive thrust faulting, and where intensively these rocks can be highly permeable and locally may form significant aquifers (Bedinger and others, 1989b); 
however, they are not widespread. Some limited sections of the rocks are also found in the southwestern portion of the Death Valley region (Bedinger and others, 1989a).

\section{Paleozoic Carbonate Rocks}

Limestone, dolomite, and calcareous shales of Paleozoic age underlie many valleys and crop out along the flanks of and throughout some mountains (fig. 8). These carbonate rocks cover an extensive portion of the area around Death Valley, extending to the north and east. They are often interbedded with siltstones and shales and locally interrupted by volcanic intrusions in the north. These carbonate rocks, which have an aggregate thickness of about $8,000 \mathrm{~m}$, are generally the most permeable rocks in the area (Bedinger and others, $1989 \mathrm{~b}, \mathrm{p}$. A17). Where hydraulically connected, they provide an avenue for interbasinal flow.

Most of the springs in the area are associated with the carbonate rocks. Intergranular flow is not significant in these rocks; the large transmissivity is primarily due to fractures and solution channels (Winograd and Thordarson, 1975). Hydraulic tests of carbonate-rock aquifers throughout eastern and southern Nevada indicate that faults can increase the carbonate-rock transmissivity by factors of 25 times or more (Dettinger, 1989).

In the NTS area, the Eleana Formation separates the carbonate rocks into upper and lower carbonate aquifers. The Eleana Formation, composed mostly of relatively impermeable argillites and shales, forms a locally important clastic confining unit. The argillites and shales tend to deform plasticly, probably by shearing and tight folding. Thus, open fractures are unlikely to occur at depth in this formation. Beneath western Yucca Flat and northern Jackass Flats, the Eleana Formation is thousands of meters thick and stratigraphically and hydraulically separates the carbonate aquifer into upper and the lower carbonate aquifers (Winograd and Thordarson, 1975). Large hydraulic gradients in these areas are attributed to the low transmissivity values of the Eleana Formation.

\section{Paleozoic-Precambrian Clastic Rocks}

Siltstone, quartzite, shale, sandstone, and some metamorphic rocks of Paleozoic-Precambrian age form clastic confining units. Regionally, these rocks vary in aggregate thickness with a maximum thickness of about $3,500 \mathrm{~m}$. These rocks permit negligible interstitial ground-water movement, but frequently are highly fractured and locally brecciated (Winograd and Thordarson, 1975). At shallow depths, the fractures and breccias can be conduits to flow, converting the clastic rocks into locally important shallow aquifers.

Clastic rocks in the region differ hydrologically from carbonate rocks in two important ways. First, secondary porosity rarely develops along bedding planes in any of the clastic rocks because of the low solubility of their constituents, which include quartz, mica, and clay minerals. Second, the clastic rocks deform more plastically than the carbonates and, as a result, fractures may become sealed or isolated during deformation (Winograd and Thordarson, 1975). In these rocks, the fractures may be sealed by continued deformation caused by the same process that formed them, or by later plastic deformation. Open fractures in interbedded competent rocks may be sealed by plastic deformation of the less competent interbedded strata (Winograd and Thordarson, 1975).

\section{Precambrian Igneous and Metamorphic Rocks}

Crystalline metamorphic rocks and igneous rocks of Precambrian age are widespread throughout the southern part of the region (fig. 8), cropping out in many mountain ranges and underlying most of the area at depth (Bedinger and others, 1989a). Hydrologically this unit behaves similarly to the other crystalline rocks in the region. Ground water is thought to occur only locally in these crystalline bodies where the rock is fractured. Because the fractures are poorly connected, these rocks act mostly as confining units or barriers to flow.

\section{Hydrology}

The Death Valley region has been delineated into twenty-eight hydrographic areas on the basis of topographic divides (Eakin and others, 1976) (fig. 9). Perennial surface-water is virtually nonexistent in the Death Valley region. Several perennial streams originate from snowmelt in the high altitudes of the Spring and Magruder Mountains. These streams have highly variable base flows, and in dry years have almost imperceptible discharges. Perennial streams fed from large-discharge springs along the lower reaches of the Amargosa River have the most consistent base flows. 


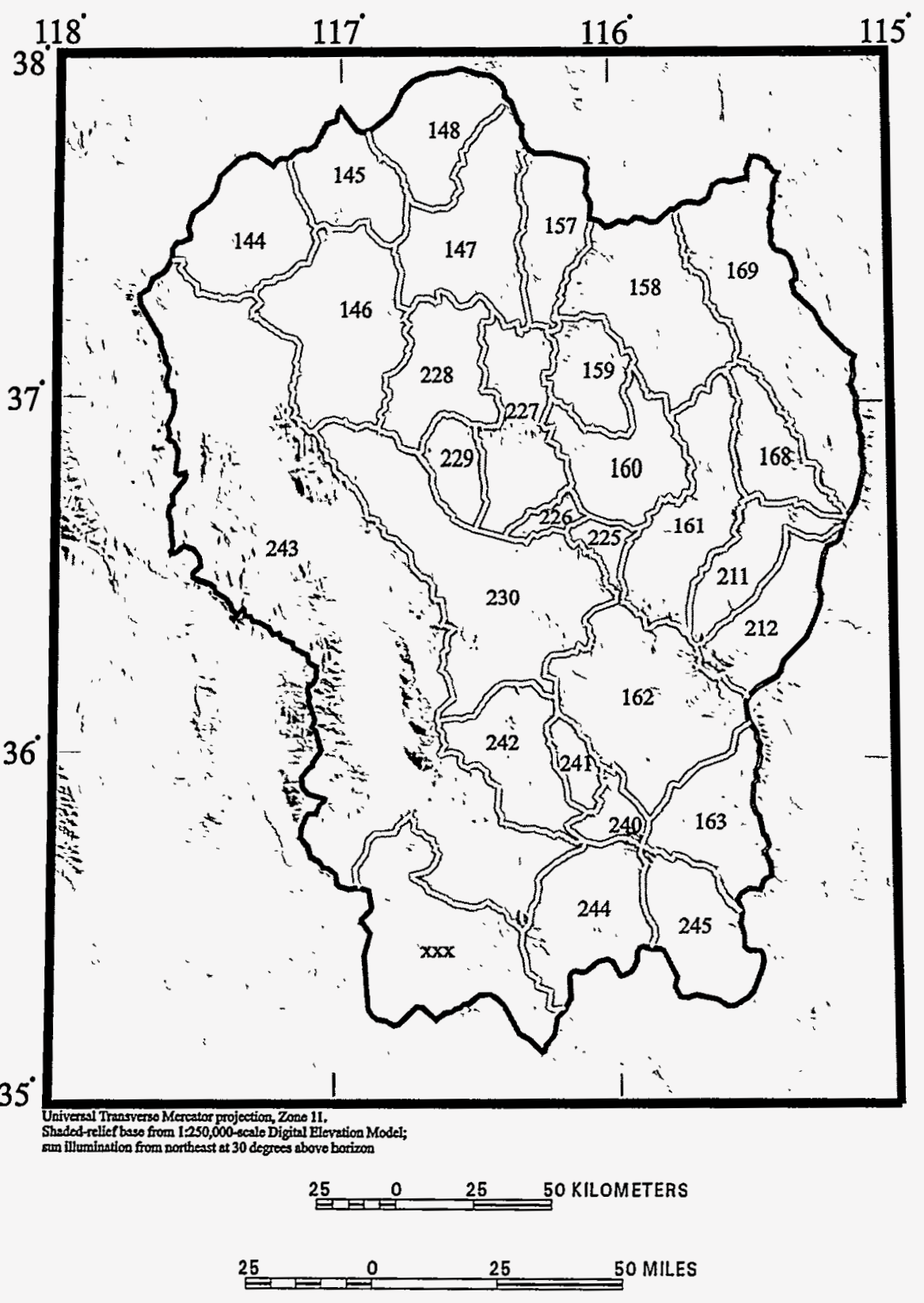

\section{EXPLANATION}

Death Valley Regional

Flow System Boundary

$\varpi$ Hydrographic area boundary

144 Lida Valley

145 Stonewall Flat

146 Sarcobatus Flat

147 Gold Flat

148 Cactus Flat

157 Kawich Valley

158 Emigrant Valley

159 Yucca Flat

160 Frenchman Flat

161 Indian Springs Valley

162 Pahrump Valley

163 Mesquite Valley

$168 \mathrm{~N}$. Three Lakes Valley

169 Tikaboo Valley

$211 \mathrm{~S}$. Three Lakes Valley

212 N. Las Vegas Valley

225 Mercury Valley

226 Rock Valley

227 Fortymile Canyon

228 Oasis Valley

229 Crater Flat

230 Amargosa Valley

240 California Valley

241 Chicago Valley

242 Lower Amargosa Valley

243 Death Valley

244 Valjean Valley

245 Shadow Valley

xxx No hydrographic area

number available

Figure 9. Hydrographic areas of the Death Valley region (from Eakin and others, 1976). 
The ground-water flow systems of the Death Valley region are extremely complex. Hydraulic compartmentalization may occur throughout the study area due to the complex geologic structure. Interbasinal flows control most of the regional ground-water flow system. Ground-water recharge results from infiltration of precipitation and runoff on the high mountain ranges (Bedinger and others, 1989a). Natural ground-water discharge is by flow to springs and by evapotranspiration (ET) in areas where the water table is near the land surface. Human-induced discharge occurs in the form of ground-water pumping for agricultural, commercial, and residential uses (Bedinger and others, 1989a).

Regional ground-water flow patterns do not coincide with topographic basins. A laterally and vertically extensive carbonate rock sequence forms the most significant regional hydraulic control because it underlies the area. Most of the regional flow is affected by structurally and lithologically induced variations in permeability (Winograd and Thordarson, 1975). Regional flow also is affected by shallow local flow systems that are controlled by recharge and discharge locations, and by the complex geology. In several places, high mountain ranges support local ground-water mounds that may act as hydraulic barriers to subsurface flow, preventing interbasinal ground-water flow. The net result of these interactions is the compartmentalization of flow into local, subregional, and regional subsystems.

\section{Land and Water Use}

Most of the land in the Death Valley region is owned by the U.S. Government and is administered by numerous Federal agencies. Privately owned land is scattered throughout the region, but most private ownership is concentrated near the agricultural centers of Amargosa Valley and Pahrump Valley, the mines near Beatty, Nevada, and the recreational gateways at Shoshone, Tecopa, and Baker, California (fig. 2).

The major land-use activities in the region include agriculture, livestock ranching, recreation, and mining. Water within the basin mostly is utilized for domestic, commercial, agricultural, livestock, military, and mining purposes. Water resources in the basin directly support the natural diversity protected by the National Park Service in Death Valley and the U.S. Fish and Wildlife Service at Ash Meadows.
These areas are protected because of the presence of rare desert oases containing endemic wildlife whose continued existence depends on naturally occurring spring discharges.

\section{USE OF GEOSCIENTIFIC INFORMATION SYSTEMS}

The hydrogeologic evaluation and numerical simulation of ground-water flow of the Death Valley region requires a quantitative and accurate $3 \mathrm{D}$ characterization of both surface and subsurface conditions. Definition of these conditions requires volumetric representation of the flow system components referenced to three orthogonal axes. The computerbased 3D data management and modeling systems designed to handle the variety of geologic, hydrologic, and geophysical data required for this study are called Geoscientific Information Systems, or GSIS (Turner, 1991; Bonham-Carter, 1995).

\section{Geoscientific Information Systems (GSIS)}

\section{Relationship Between GSIS and GIS}

GSIS include 3D extensions of traditional 2D GIS capabilities in order to represent subsurface geologic features, geometries, and properties. Although GIS technologies are widely used over a wide spectrum of applications, GSIS developments are directed toward a much smaller and specialized market. Therefore, GSIS are less mature than their GIS counterparts and have been forced by economic necessity to adapt methods developed for other applications to satisfy GSIS requirements.

A GIS is a computerized data-base management and modeling tool used for the capture, storage, retrieval, analysis, transformation, and display of spatial, or locationally defined, data (Burrough, 1986). GIS are concerned mostly with 2D, areal, spatial relations. The altitude of the Earth's surface is frequently of little or no consequence in GIS applications, and for many geographic analyses, can be treated as an attribute of spatial location. Accordingly, most GIS accept and manipulate only 2D spatial data, and provide only limited 3D data display capabilities.

GIS analyses support a tremendous variety of applications and utilize numerous data management, 
analysis, and display methods. Two main categories of GIS, termed raster and vector systems, use different methods to describe spatial relations. Raster GIS represent the area being studied as an array of small, uniform-sized cells, usually square or rectangular in shape. Each cell is coded to reflect the dominant value or class of the map feature being represented by the cell. Spatial relations are readily derived from the positions of the cells. In contrast, vector GIS represent map features as digitized points, lines, and polygonal areas. Spatial relations are defined by topological relations among the point, line, and areal features (Burrough, 1986; Bonham-Carter, 1995).

\section{Classes of GSIS}

The 3D GSIS technologies also may be divided into two major classes according to their method of defining spatial volumes (fig. 10) (Fried and Leonard, 1990). Volume representation methods divide the volume into discrete volume elements, or voxels, and so are the equivalent of $2 \mathrm{D}$ rasters. Surface representation methods are the $3 \mathrm{D}$ equivalent of vector GIS, but were not used in this study.

The majority of available commercial GSIS utilize voxels because they offer commercial advantages and they allow rapid development of specialized applications. Voxel representations can require very large amounts of data storage; a lowresolution volume representation may exceed $1,000,000$ voxels, and consequently volumes represented by tens or hundreds of millions of cells may be desired. Many geologic features are relatively thin and widespread, and some commercial GSIS reflect this characteristic by allowing partially deformable "geocellular" voxels that have uniform dimensions in the $x$-and $y$-directions and variable dimensions in the $\mathrm{z}$-direction. Other commercial GSIS convert a voxel data structure into a 3D isosurface prior to display (Smith and Paradis, 1989; Paradis and Belcher, 1990).

\section{Role of GSIS}

The role of GSIS extends beyond merely modeling complex subsurface geometries and can be defined in terms of four interrelated fundamental modules (fig. 11) (Turner, 1989). GSIS performs the central role of data management and visualization during the entire modeling process, and therefore, must interact with the other modules (fig. 11).

The subsurface characterization module provides analytical techniques to synthesize geologic experience and limited field data to convert isolated observations into a fully integrated $3 \mathrm{D}$ volumetric distribution of geologic properties or features. This subsurface characterization process is linked in a circular fashion to the GSIS module. A number of iterations can be expected before the most probable subsurface conditions are defined. In some cases, a unique solution may not be achievable and two, or more, alternative characterizations may result. Once a suitable subsurface characterization has been defined, the modeling process involves a second cycle, shown on the right of figure 11, where the GSIS interacts with numerical process models. The GSIS provides input parameters required by the flow model and accepts model results for visualization and statistical analysis.

Evaluations of the usefulness or reasonableness of the subsurface characterizations and validation of the numerical model results require statistical screening techniques. These techniques provide additional information exchanges. Sensitivity of the numerical model predictions to variations or uncertainties in the model input parameters can be evaluated by the combined use of all modules. Individual parameter estimates are changed using the GSIS capabilities, and a new sequence of numerical model runs are undertaken. Or the entire subsurface characterization may be reevaluated to reflect new data or a different interpretation and then can be analyzed by additional numerical modeling.

\section{GSIS Software Products Used in the Project}

Several commercial GIS, GSIS, and sophisticated gridding and contouring software products were selected for use by the project. At the time this project was planned, no single product could adequately support all project requirements, but individual products offered particular capabilities that satisfied specific project needs, and the entire suite of products formed an integrated data management network (fig. 12). The scope and magnitude of this project frequently placed demands on these systems that exceeded those posed by previous applications. Consequently, collaborations with software development teams at the various companies were utilized to efficiently resolve difficulties as they arose. 


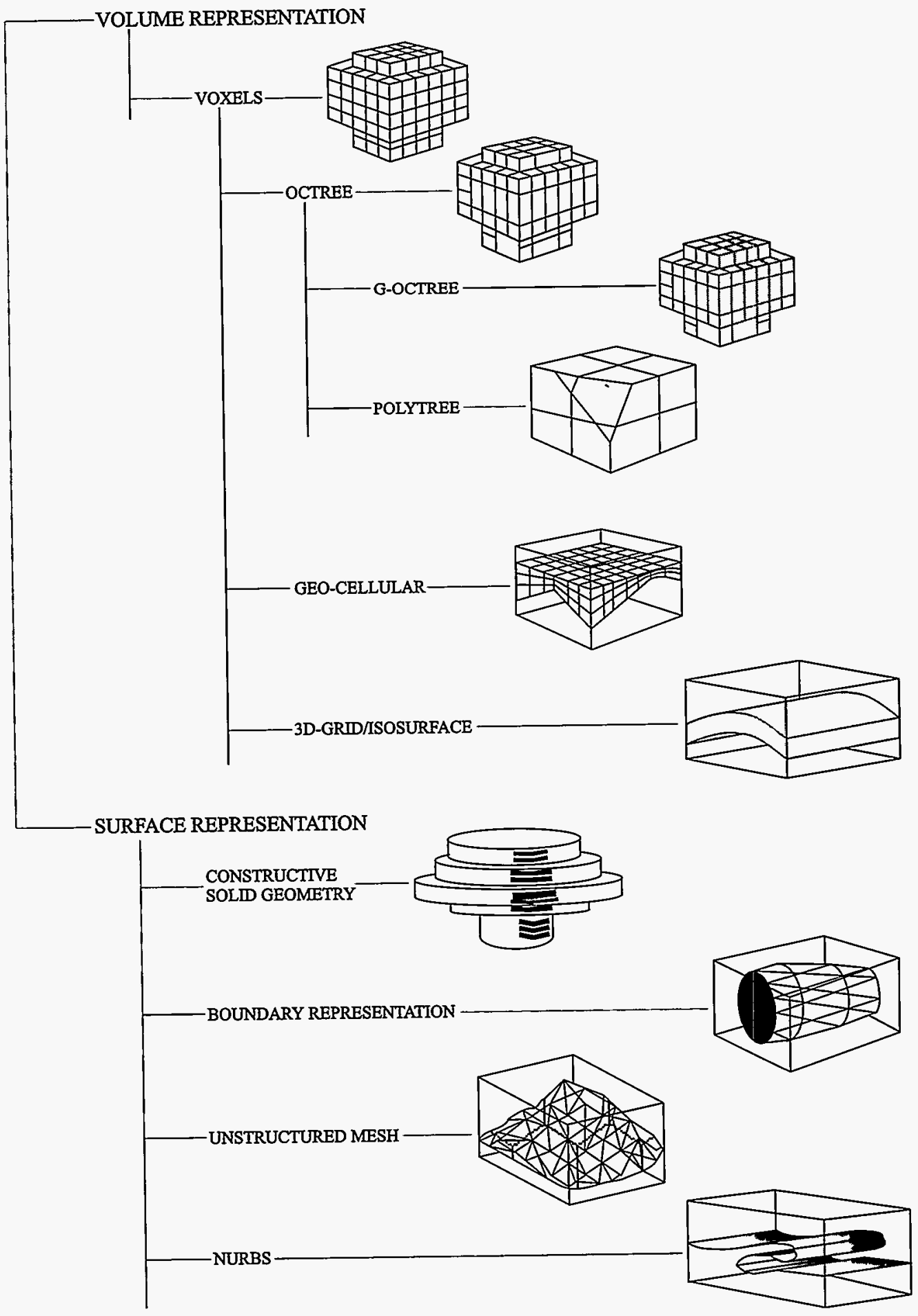

Figure 10. 3D spatial representations. 


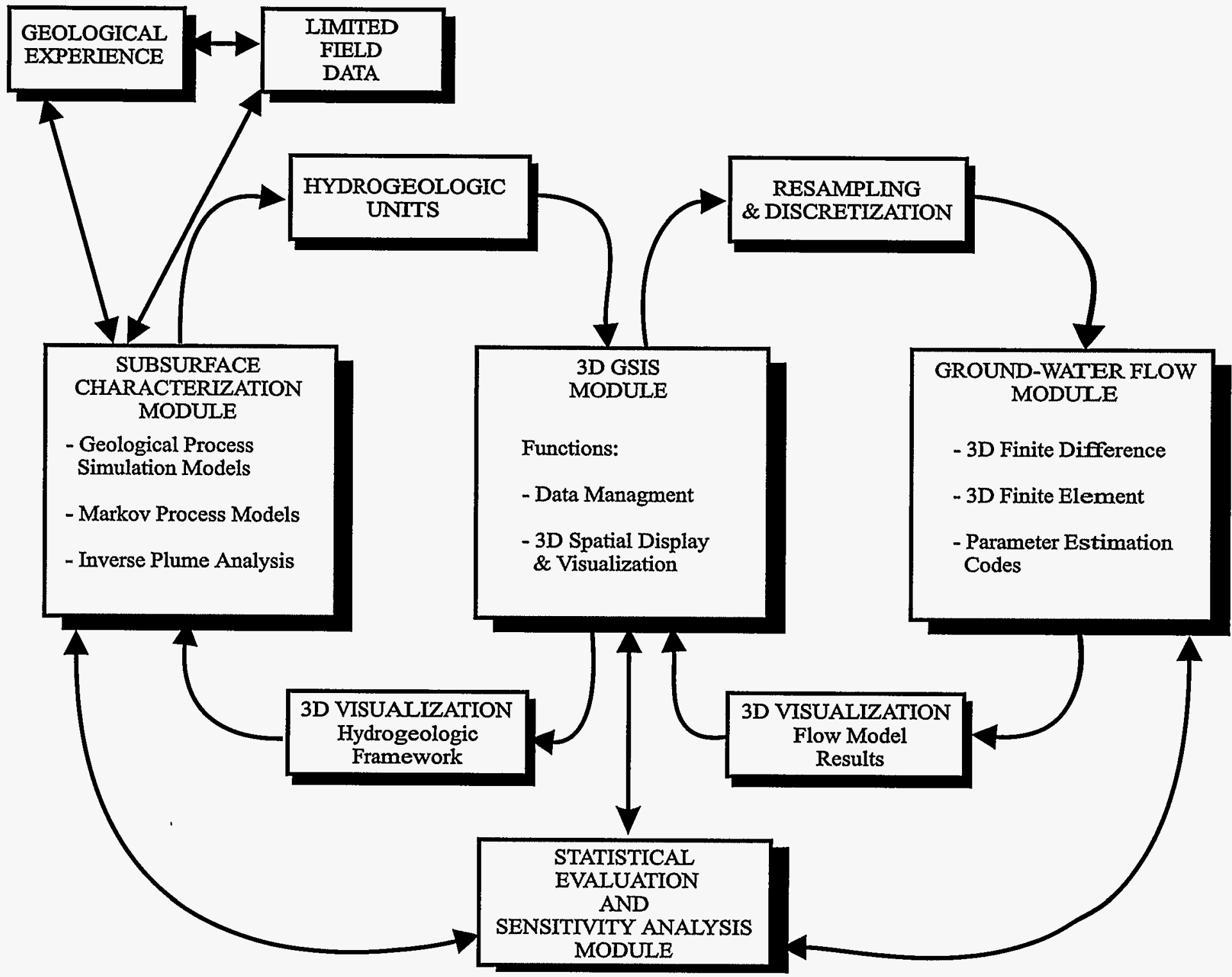

Figure 11. Information flow and the role of GSIS (modified from Turner, 1989). 


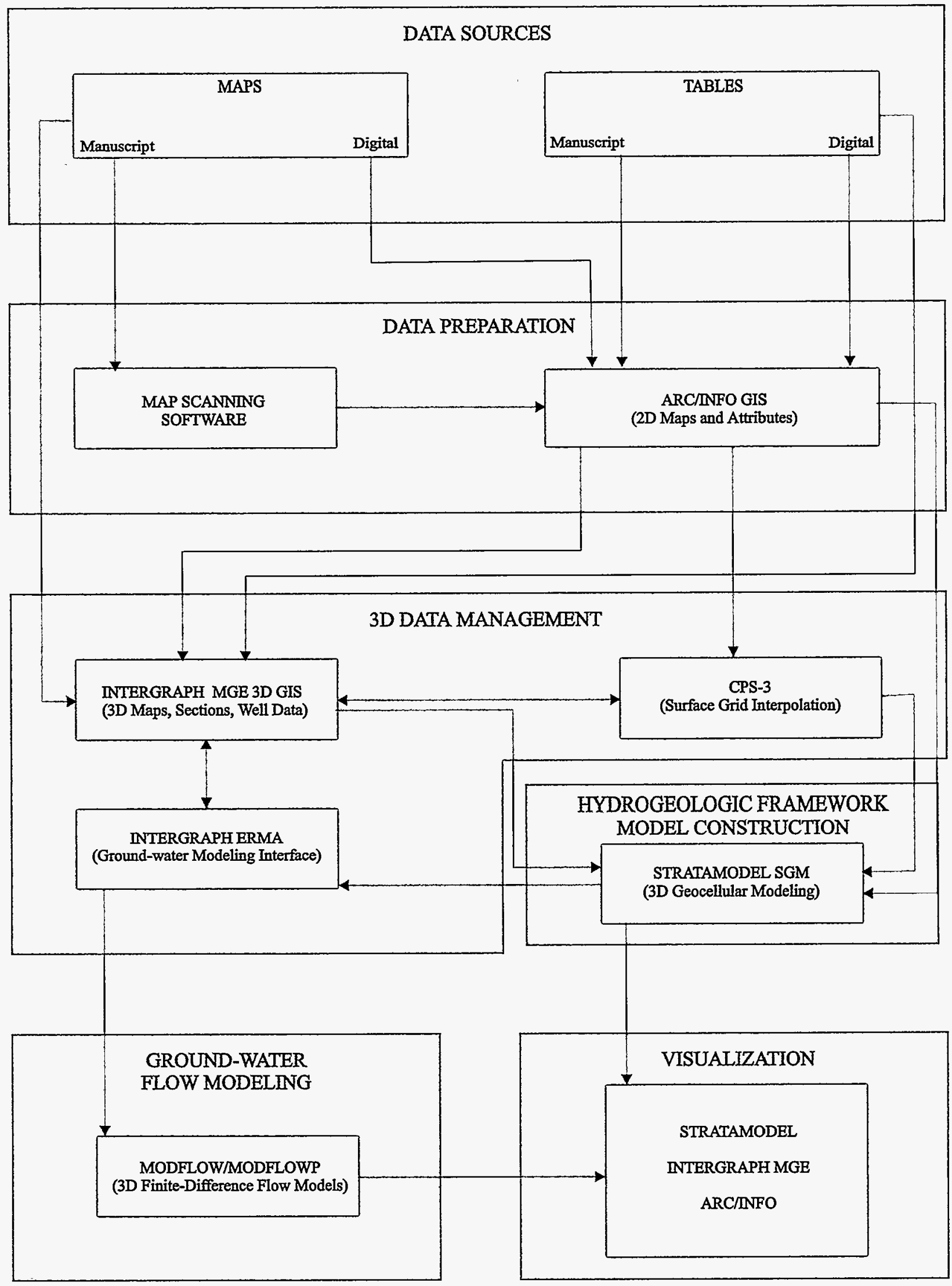

Figure 12. Integration of commercial GIS, GSIS, and gridding and contouring software used by the project. 
Figure 12 illustrates the data flows among the various system components. Existing information sources provided maps or tabular data. Some data already existed in digital formats, although other data only were available as maps or tables and required digital conversion. Most maps were converted to digital form by a large-format scanner. ARC/INFO system, developed by Environmental Systems Research Institute, was used to: (1) conduct preliminary data editing and preprocessing of existing GIS data, and (2) provide alternative methods of conducting raster-based map analyses and manipulation of numerical ground-water model arrays through use of the ARC/GRD module. A continuing constraint was that ARC/INFO is a strictly 2D GIS system with some limited 2.5D capabilities, and does not support 3D data.

The core of the modeling effort was a suite of GIS and GSIS products, by Intergraph Corporation that provided full 3D support and direct links between the spatial data and relational data bases, and a formsbased data transfer protocol between these applications and selected numerical ground-water models. These products provided many of the required data management, analysis, and synthesis capabilities, along with the data transfer protocols for the numerical models.

Two additional software products were employed to support sophisticated data interpolation and stratigraphic model construction functions. The CPS-3 gridding and contouring package, Schlumberger-GeoQuest Corporation, was used to develop interpolated stratigraphic surfaces that reflected stratigraphic observations and discontinuities created by regional faulting. The Stratigraphic GeoCellular Modeling product (Stratamodel SGM), owned and marketed by Landmark Graphics Corporation, was used to combine the individual stratigraphic surfaces produced by CPS-3 to form a 3D geocellular model of the regional hydrogeologic framework.

Visualization of the various digital models produced throughout this process was accomplished by using the capabilities of the various software products. Arrays representing hydrogeologic parameters for selected layers of the numerical ground-water flow model were developed from the Stratamodel SGM representation of the regional hydrogeologic framework. These arrays were provided to the numerical ground-water model by using the forms interface within the Environmental Resource Manage- ment Applications (ERMA) system, Intergraph Corporation.

\section{Design of GSIS Centralized Data Base}

Modeling of the Death Valley regional groundwater flow system is based on a systems definition approach that defines complex natural phenomena as systems composed of dynamically interrelated components (Harbaugh and Bonham-Carter, 1970). Interactions among these components define the system responses.

The Death Valley regional ground-water flow system has two major system elements:

1. The 3D hydrogeologic framework that established the internal controls of the regional flow system, and

2. The surface and subsurface hydrologic conditions that defined the connections to the larger regional and global hydrologic systems and cycles.

Several data categories were evaluated to define these system elements, and a centralized GSIS data base was used to organize and assimilate the relevant information.

\section{Definition of Data Categories}

Ten principal data categories were used to define the Death Valley regional ground-water flow system: geology (including both stratigraphic and structural information), geophysics, geomorphology, topography, hydrochemistry/geochemistry, remote sensing, vegetation and land use, soils, hydrology, and climate (fig. 13). A literature search was conducted to identify appropriate information that described regional conditions for these data categories within the geographical area of interest. Only well-documented publicly available data were able to satisfy the data quality assurance criteria mandated for this study. For example, water-level data were only used if they had been previously published, or quality-controlled and stored in publicly accessible data files.

Much of the existing information required preprocessing or preliminary analysis to make the data useful for conceptualization and evaluation of the regional flow system. For example, remotely sensed data required preprocessing to develop thematic maps defining regional vegetation conditions that, in turn, were used to establish recharge or discharge 


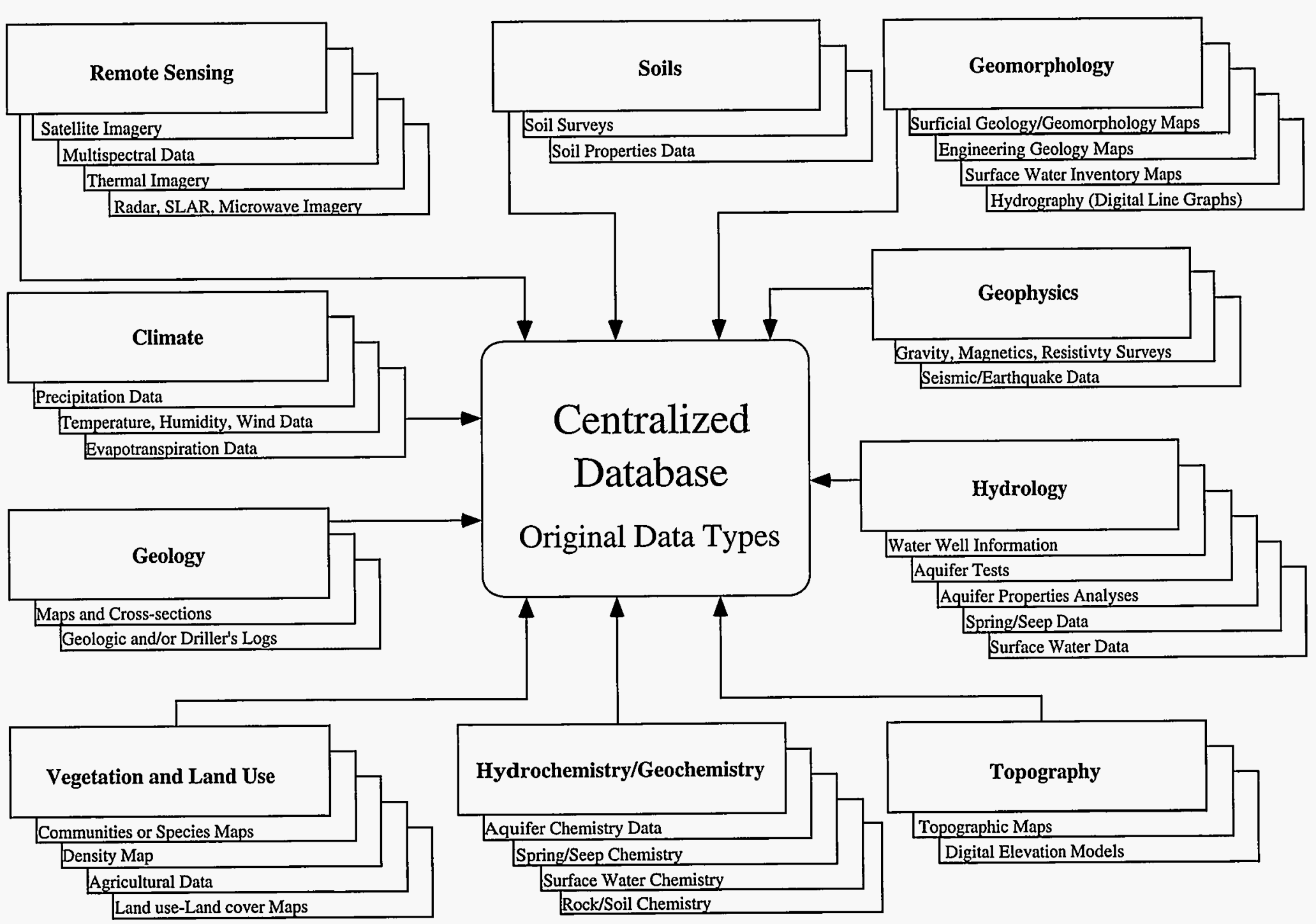

Figure 13. Data categories selected and incorporated into standardized GSIS data base. 
conditions. A GIS was used to initially analyze geologic maps, while other data, such as lithologic logs and climatic data, were acquired and incorporated into the centralized GSIS data base as tabular entries. Therefore, many of the data categories shown in figure 13 involved individual data bases, but the centralized data base contained the data required to operate the numerical ground-water flow model, and the results produced by that model. This data base was developed and stored in the ERMA system.

\section{Data Categories Defining the Hydrogeologic Framework}

The hydrogeologic framework defines the physical geometry and rock types of the subsurface materials through which the ground water flows. Two primary data categories (geology and topography) were used to define the hydrogeologic framework.

The geology data category defines the fundamental nature of the ground-water flow system because it defines the hydrogeologic units and structures. Topography, which is often the result of geology, determines and controls many of the driving forces of the hydrologic system (Hollett and others, 1991). Depending on their characteristics, geology and topography may affect the magnitude and location of recharge areas and enhance or inhibit the movement of ground water. Bedrock permeability and the presence of mountain ranges influence the local, subregional, and regional flow paths.

\section{Data Categories Defining Surface and Subsurface Hydrologic Conditions}

The geometries of the water table and flow-path components of the Death Valley regional groundwater flow system are greatly influenced by surface and near-surface hydrologic conditions. Six data categories (remote sensing, vegetation and land use, soils, hydrology, climate, and topography) were used to define these surface and subsurface hydrologic components for the regional model. The Death Valley regional flow system includes processes that deliver water to the water table by deep infiltration (recharge) and remove water from the water table by base flow to streams, soil storage, spring discharge, and ET (discharge). Human activities affect the ground-water flow system by ground-water withdrawals for various consumptive uses. Limited irrigation in the region has affected local ground-water flow patterns, and represents an additional ground-water withdrawal.

The soil-plant-atmosphere system involves very complex hydrologic interactions that occur at or near the land surface. Previous investigations (Eakin and others, 1976; Bedinger and others, 1989a) identified the critical components for this region, and provided the basis for the necessary generalization of these complex interactions for regional modeling purposes.

Net recharge to the system is from precipitation. Rain and snowfall on the highest mountain altitudes are the main sources of recharge to the regional ground-water flow system. The proportion of precipitation that actually infiltrates and recharges the ground-water system is affected by the mantle of regolith, soil, and vegetation, which in turn are controlled by climate. Interpretation of remote sensing data produced qualitative vegetation maps that, when combined with soils, vegetation, and landuse data produced geomorphic-vegetation classes having distinctive infiltration potentials. Climate data, combined with topographic data, provided the basis for estimating precipitation rates.

Net natural discharge from the regional groundwater flow system is dominated by evaporation and transpiration of water supplied to the surface by shallow water table conditions or spring discharge (Bedinger and others, 1989a). Where spring discharge is of considerable volume, overland flow occurs; however, no water leaves the system as overland flow (Eakin and others, 1976). All surface water is either evaporated, consumed by phreatophytes shortly after reaching the surface, or is diverted for human consumption. As a result, estimation of losses due to water evaporation from bare soils and free water surfaces and water transpiration by phreatophytes is required to determine natural discharge rates. Humaninduced water losses were accounted for by estimation of pumping for agricultural, commercial, industrial and municipal uses. Estimated discharge rates, developed from soils, vegetation, and land use data, were supplemented by interpretations of remote sensing, surface hydrology data, and human-induced ground-water withdrawal records. 


\section{Construction of GSIS Centralized Data Base}

The creation of 3D conceptual and numerical models of geologically and hydrologically complex regions, such as the Death Valley region, demands careful data management and quality controls (Turner, 1992). The identification, acquisition and conversion of suitable data, and the application of appropriate processing and analysis procedures to these data, are critical for successful characterization and conceptualization. The procedures used to process existing information sources to construct the data base, while maintaining data quality assurance standards, depend more upon the format in which the information can be obtained rather than on any topical considerations. For example, all manuscript map sources were digitized, edited, and quality assured using one set of procedures, while all tabulated data were entered into the data base by using another set of procedures. The construction of the data base can be most easily described by classifying the various acquired data into one of four classes: (1) existing digital GIS files, (2) publicly available spatial data, (3) published maps and cross sections, and (4) tabulated data in reports and files. Each class of data required the application of different preprocessing procedures to convert the data into usable formats and maintain appropriate quality assurance standards.

\section{Existing Digital GIS Files}

Several information sources were available as archived digital GIS data files. These contain both graphical component files and corresponding structured data attribute tables that may be used directly for data analysis and characterization. Data conversion requirements for these files are rather straightforward, consisting primarily of importation into the desired GIS from an archived format. For this study, two such data sources were available in the ARC/INFO GIS archival format:

1. Statewide soils maps for California and Nevada within the U.S. Department of Agriculture (USDA) Soil Conservation Service (SCS) State
Soil Geographic Data base (STATSGO) (U.S.

Department of Agriculture, 1991), and

2. A digital representation of the geologic map of

Nevada (Turner and Bawiec, 1991).

Both data sets are constructed at an appropriate scale of resolution and accuracy for regional characterization. The STATSGO data provided soils information that was used to locate and map discharge areas. A portion of the Nevada geologic map was used in the construction of the hydrogeologic framework model (fig. 14) (Faunt and others, in press). These files were processed to extract the data within the study area, edited as necessary, and their attributes were stored within the data base.
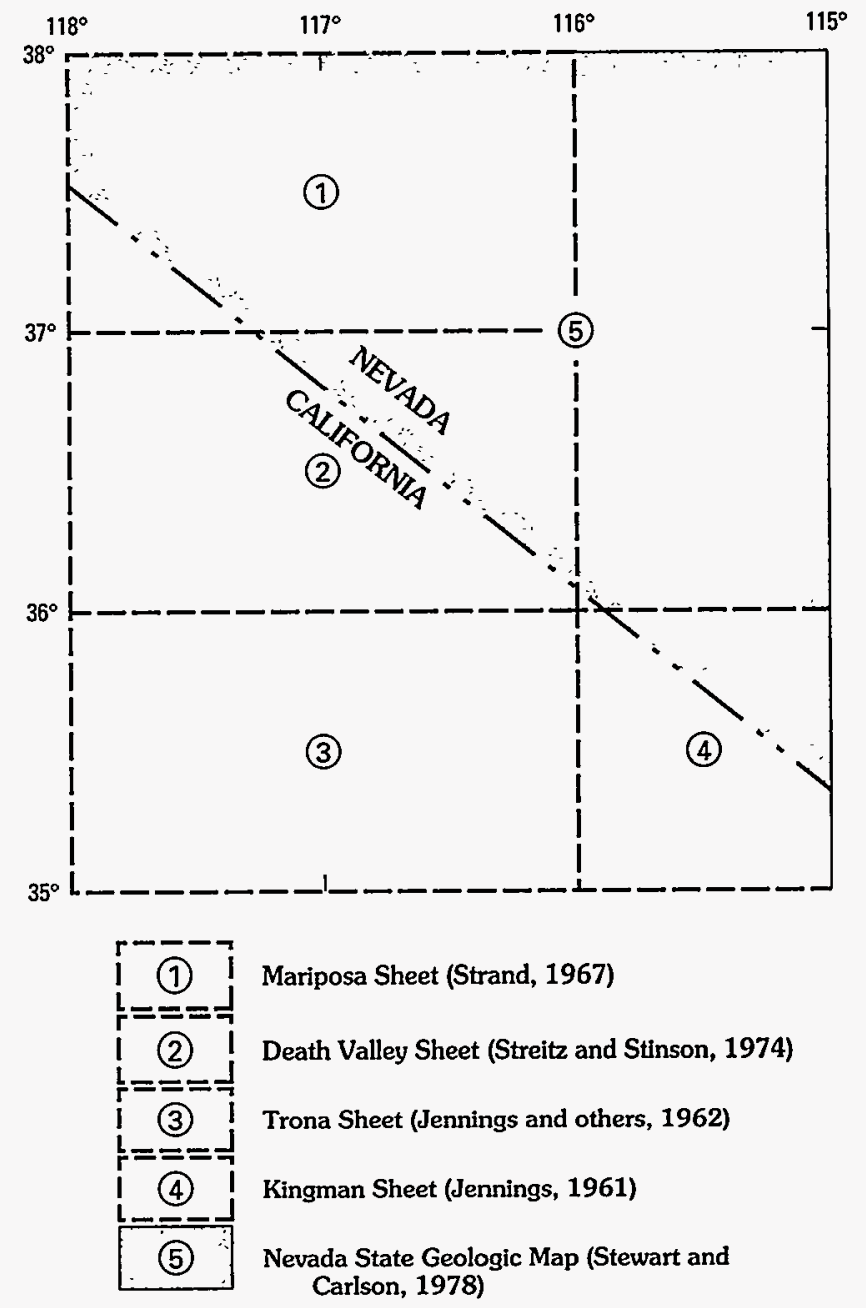

Figure 14. Map sheets used to compile surface geologic data. 


\section{Publicly Available Spatial Data}

Publicly available spatial data include digital data sources available from Federal entities in standardized archival formats that are not linked to any specific GIS. These data require several preprocessing steps to import them into a desired software and to extract desired thematic layers. In some cases, data quality assurance checks uncovered discrepancies between sources describing adjacent map quadrangles. In most cases, these discrepancies were related to differences in the source documents that could be related to different dates of map creation. Data parsing and editing procedures were followed to create consistent mapped conditions throughout the study area. This study used the following data sources in this class: (1) digital elevation model (DEM), (2) digital line graphs (DLG's), (3) land use/land cover (LU/LC) data, and (4) Landsat Thematic Mapper (TM) satellite imagery.

Elevation data derived from USGS 1-degree DEMs were combined, resampled, and geographically transformed into the Universal Transverse Mercator (UTM) coordinate system (Turner and others, 1996a). This resampled, digital terrain model was used to develop two, raster-based maps required by the study. The first was a digital map that classified topographic altitudes according to regular $100 \mathrm{~m}$ contour intervals. The second was a map that defined slope-aspect, or dominant slope-facing azimuth, according to five classes (slopes facing northeast, southeast, southwest, northwest, and flat, or no azimuth).

Surface hydrographic features were defined from data sources that utilized the Digital Line Graph (DLG) format and contained information derived from 1:100,000-scale map sources. Four ARC/INFO map coverage themes were developed: hydrographic data area features (lakes, salt flats, playas, and reservoirs), hydrographic data line features (streams, rivers, ditches, and canals), hydrographic data point label features (stream origins and locations of inflow and outflow to (and from) water bodies), and hydrographic data degenerate line features (springs and wells) (Turner and others, 1996b). Two additional ARC/INFO maps, representing LU/LC conditions and boundaries of the standard USGS-defined hydrologic units, were developed from data sources that utilized the Geographic Information Retrieval and Analysis System (GIRAS) format and contained information derived from 1:250,000-scale map sources (Turner and others, 1996b).

Landsat TM satellite images were obtained from a federally owned satellite-image data base. These data were selected to provide cloud free coverage during spring or early summer of consecutive years. These data were georegistered to the UTM projection using 1:250,000-scale topographic base map sheets, and ortho-rectified to north at $100-\mathrm{m}$ intervals. As a result, the data were easily imported into the GSIS data base and stored as image data in separate bands.

\section{Published Manuscript Map Information}

The major nondigital map source used by this study were parts of four 1:250,000-scale geologic maps that cover the California portion of this region (fig. 14) (D'Agnese and others, 1995; Faunt and others, in press). In addition, 32 regional interpretive cross sections (fig. 15) developed at 1:250,000 scale for the Death Valley region (Grose and Smith, 1984; Grose, 1983; Bedinger and others, 1989d) were digitized. These cross sections were used to help define the subsurface hydrogeologic framework of the region.

\section{Tabulated Data in Reports and Files}

Data conversion and preprocessing of published or tabulated data generally involves two forms of data manipulation: (1) data entry of manuscript or published data into computer compatible format, or (2) data reformatting of existing digital files and data bases. In this study, both forms of public-access data were used. Tabulated data used for the project includes:

1. Water-well data including well locations, site identification, water levels, water-use codes, land surface altitude of well, and well depth;

2. Tabulated data in reports containing information on spring locations, water levels, spring discharge rates, and ET rates;

3. Mathematical relations developed by previous investigators used to describe natural phenomena; and

4. Lithologic log data, including well location and depth and hydrogeologic unit tops;

Most water-well data used in this study originate from public-access files of the USGS's NWIS data base. These files contain a detailed 


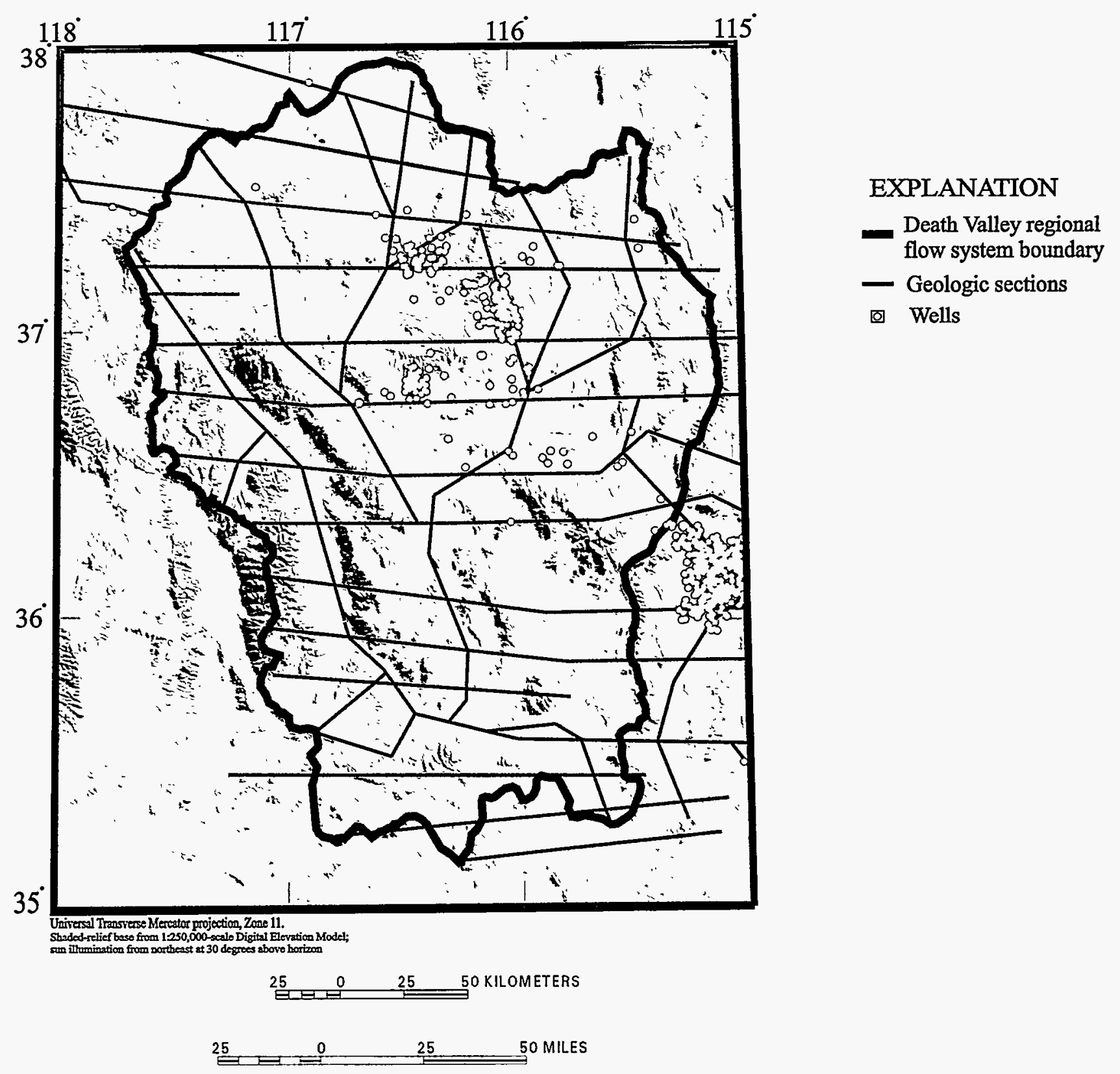

Figure 15. Locations of subsurface data used to construct the hydrogeologic framework model.

account of characteristics for wells and springs in an elaborate data structure. A detailed query of the data base was undertaken to retrieve data that would be useful for analyzing water levels and water use in the region. An additional query of the NWIS data base was conducted to retrieve water-use information. These data were converted into a format compatible with the GSIS data base.
Additional data concerning spring locations and water levels, spring discharge rates, and ET rates that were important to this study were found in miscellaneous published reports. These data were converted into a digital format by key entry procedures and were either incorporated into existing maps and attribute tables, or stored in ancillary tables in the standardized GSIS data base for later use. 
Published maps produced from previous regional hydrogeologic studies in the Great Basin provide a wealth of information about the Death Valley regional ground-water basin (Thomas and others, 1986; Harrill and others, 1988). Although not in digital forms, these data are extremely useful for evaluating previous conceptual models. Data defining the boundaries of surface- and ground-water basins were converted into digital format. Lithologic logs for wells within the region were used to supplement the cross section data for defining the subsurface geology (fig, 15).

\section{CHARACTERIZATION OF THE REGIONAL HYDROGEOLOGIC FRAMEWORK}

\section{Construction of 3D Digital Hydrogeologic Framework Model}

Development of a 3D hydrogeologic framework model for the Death Valley region began with the assembly of primary data: DEM, geologic maps, cross sections, and lithologic well logs. Each of these data types were originally manipulated by a standard GIS; however the merging of these diverse data types to form a single coherent $3 \mathrm{D}$ digital model required more specialized GSIS software products.

Construction of the 3D hydrogeologic

framework model involved four main stages:

1. A DEM was combined with geologic maps to provide a series of points locating the outcropping surfaces of individual geologic formations.

2. Cross sections and lithologic well logs were properly located in 3D space to define locations of hydrogeologic units and faults in the subsurface.

3. While incorporating the effects of major faults, surface and subsurface data were interpolated to define the tops of hydrogeologic units.

4. Utilizing appropriate stratigraphic principles to combine hydrogeologic unit surfaces, a hydrogeologic framework model was developed to a represent the stratigraphic and structural relations.

\section{Integration of DEM and Geologic Map Data}

A surface hydrogeology map (fig. 8) provided verification for other model-building data and was the $2 \mathrm{D}$ foundation upon which the rest of the model was constructed. The definition of hydrogeologic unit outcrops were defined by integrating the hydrogeologic map and the DEM. The DEM defined an array of points in which each point was located by its $x, y$ and altitude coordinates (z). Points falling within each outcrop area were tagged with the corresponding hydrogeologic unit code. The resulting point map was exported as a series of ASCII files, each containing a series of $\mathrm{x}, \mathrm{y}, \mathrm{z}$ points for a single hydrogeologic unit.

\section{Use of Cross Sections and Well-Log Data}

Thirty-two cross sections for the Death Valley region were developed by Grose (1983) and Grose and Smith (1984) (fig. 15). The interpretive cross sections were developed at 1:250,000 scale. The sections were based on the hydrogeologic units defined by Bedinger and others (1989a) and reflect a consistent interpretation of regional structural style. Furthermore, Grose and Smith's hydrogeologic units were combined into ten hydrogeologic units for this study (table 1).

Each cross section was scanned to form a 2D file of line strings that represented the tops of hydrogeologic units. Map locations of each section trace were digitized and registered to geographic coordinates. The software allowed the sections to be accurately placed in 3D space by merging, scaling, and warping each section to fit its digitized trace (fig. 16). Each hydrogeologic unit was defined by a code within the data base. The sections were then linked to this data base, or attributed, by pointing to each hydrogeologic unit top displayed and keying in the appropriate hydrogeologic unit data base code. This formed an attributed section.

Each attributed section was queried to determine the altitudes of points spaced every $500 \mathrm{~m}$ horizontally along the top of each hydrogeologic unit. These points were posted in their proper 3D geographic location. After all sections and hydrogeologic units had been queried, the data base files were exported as a series of ASCII files, each containing $\mathrm{x}, \mathrm{y}, \mathrm{z}$ coordinates for a single hydrogeologic unit.

Approximately 700 wells in the region contain hydrogeologic unit tops that could be used to help correlate between the sections. The geologic units shown in the well records were reclassified into the 10 


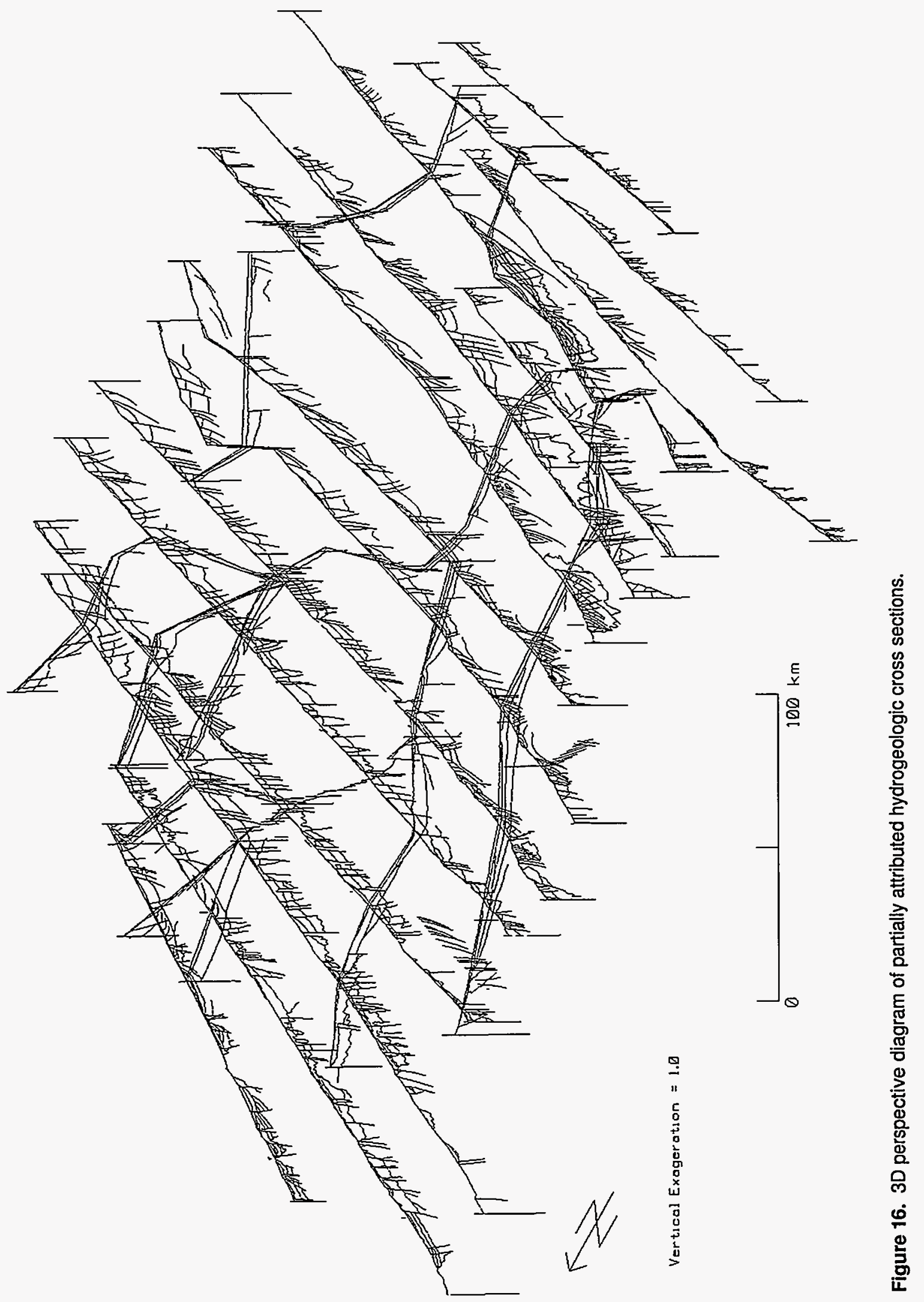


hydrogeologic units and the locations defining the top of each hydrogeologic unit were extracted and placed in a separate file. Initially, these values defined location by $\mathrm{x}$ and $\mathrm{y}$ well coordinates and depth from the ground-surface. In order to be consistent with the other altitude data being used, the altitude of the top of each hydrogeologic unit was determined by subtracting its depth from the DEM at the well location. The $\mathrm{x}, \mathrm{y}, \mathrm{z}$ coordinates derived from all wells for each hydrogeologic unit were placed in individual ASCII files.

\section{Interpolation of Structural Surfaces for Hydrogeologic Units}

The surfaces defining the locations of the top of each hydrogeologic unit were interpolated and extrapolated from available land-surface and subsurface data points, while taking into account fault discontinuities. The CPS-3 gridding system and fault handling package was used to interpolate the hydrogeologic surfaces defined by the ASCII files containing $x, y, z$ points from cross sections, well logs, and surface exposures.

The regional geologic maps showed far too many faults to be processed during the 3D model construction (fig. 17). Faults were examined to determine those that appeared significant to both the 3D framework and numerical flow model definitions. Faults were considered insignificant to the 3D model construction process if their mapped traces were shorter than $5 \mathrm{~km}$, or they had less than $750 \mathrm{~m}$ of vertical offset, or did not appear to cause offsets of any units in the cross sections. Named regional faults were retained, even when they did not meet these criteria.

The simplified fault-trace map (fig. 18) was compared with the faults shown on the cross sections. Some fault traces on the map were extended where necessary to connect to section faults and some faults shown on the sections required interpretation of the fault trace when they lacked mapped surface expressions. When fault selection and construction were completed, approximately 300 faults remained for constructing the framework model.

A convergent gridding algorithm was used to perform the grid estimation. A grid was defined with an increment of $558 \mathrm{~m}$; this resulted in a grid with 602 columns and 493 rows. The convergent gridding process involves several iterations to converge on an optimal grid definition. Faults were assumed to be vertical and the fault trace map was used in all iterations of the gridding process (fig. 18). The first iteration of the convergent gridding process generates a coarse grid that is progressively refined. During an iteration, existing data points were snapped to nearby grid nodes using a distance-weighing technique such that data points closer to the node, but not across a fault, had a larger effect on the outcome. When several data points were snapped to the same grid node, a weighted average blended the data values. During each iteration the goodness-of-fit between the grid and the data was monitored to determine if more iterations were necessary. The effect of this iterative process caused a trend-like solution in areas of sparse data, while the grid accurately represented existing data points.

Thrust faults and mushroom-shaped intrusions cannot presently be represented by a gridding process. Simplifying techniques were used to handle these limitations. Where units were repeated by thrust faults, two different grids were created for the same hydrogeologic unit. A unit extent boundary trace was then added to define an outline for the edge of the thrust sheet. Within this boundary, hydrogeologic unit altitude values defined unique additional hydrogeologic units, which could later be given the same attributes as their corresponding standard units.

Where intrusions mushroom, a suitably-sized cylindrical fault was created at the appropriate location to define the intrusion neck. For each intrusion, the intrusion neck and the top of the mushroom were treated as separate hydrogeologic units.

The quality of individual gridded surfaces depends on the available defining data points. Some hydrogeologic unit surfaces were relatively welldefined by numerous well-distributed data points. Other surfaces, including those units that crop out less frequently, were less well defined and were extrapolated from sparser data.

\section{Development of 3D SGM Framework Model}

The 3D hydrogeologic framework model was constructed from the set of interpolated surfaces representing the tops of individual hydrogeologic units. Because these surfaces were developed independently, they may extend beyond their actual limits. SGM, which uses geologic rules to help define 


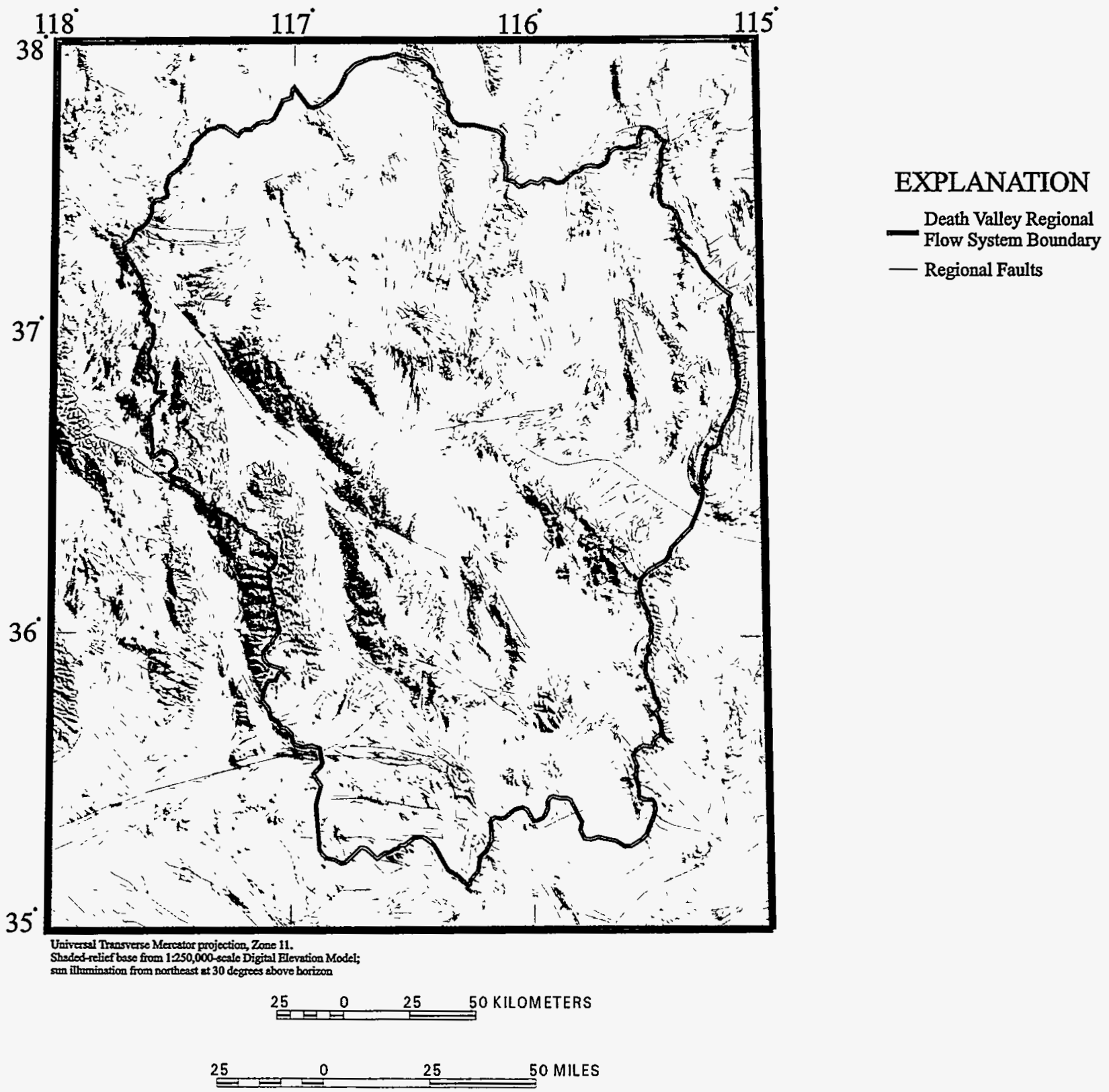

Figure 17. Traces of mapped regional faults.

the geographic extent and intersection of surfaces, was specifically developed to accurately represent stratigraphic and structural relations of sedimentary basins. These relations include onlap and proportional units as well as truncation of units and faulting.

The basic hydrogeologic framework was constructed by importing 2.5D grid surfaces to define the geologic horizons, discontinuities, and the appropriate stratigraphic sequence (fig. 19). Although the cells have uniform horizontal dimensions throughout the model, the geoscientist controlled the number of cell layers within the vertical extent of each stratigraphic unit.

SGM has not been designed to handle the timestratigraphic emplacement of intrusions. In order to model these features, they were inserted into the SGM model out of their correct time sequence (fig. 20).

Therefore, the youngest intrusion represented the oldest deposition surface. Although this did not affect the resulting model, it did affect the order the 

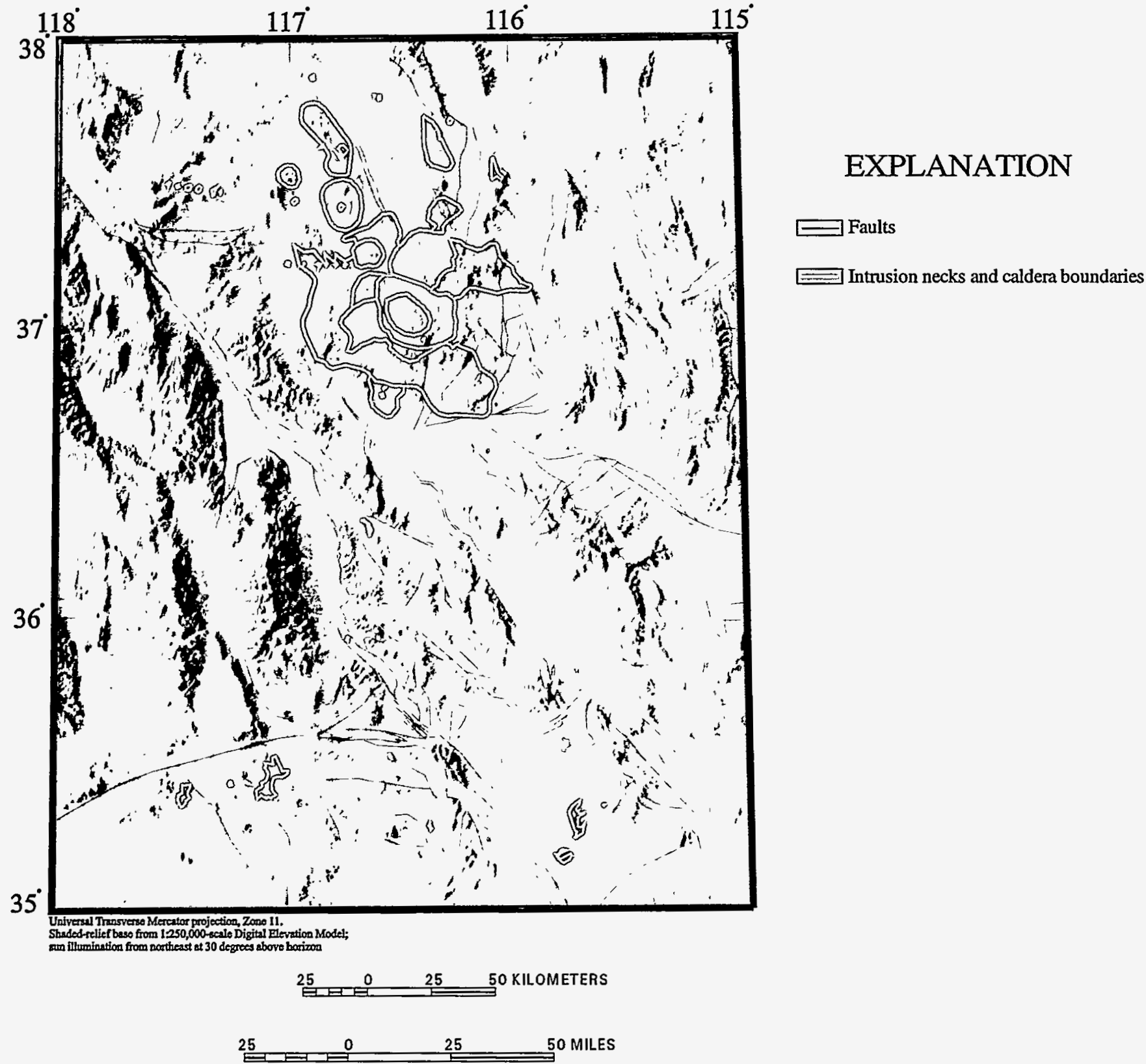

Figure 18. Traces of features used to create 3D hydrogeologic framework model.

units were put into the model. Only the geologic units and structures above $10,000 \mathrm{~m}$ below sea level were modeled. The resulting model had numerous volumetric units defined by the intersecting hydrogeologic surfaces. In many locations these volumetric sequences had large thicknesses. In order to improve the vertical resolution, the sequences were subdivided into layers so that the maximum thickness of any layer was $500 \mathrm{~m}$. As many as 60 layers were used to form the solid model. The $558 \mathrm{~m}$-increment grids for each hydrogeologic unit were resampled to a $1,500 \mathrm{~m}$ resolution providing a model with 225 rows and 184 columns of cells. This was sufficiently detailed to support the regional hydrogeologic modeling effort and allowed the entire area to be displayed as a single model with the available computers. 


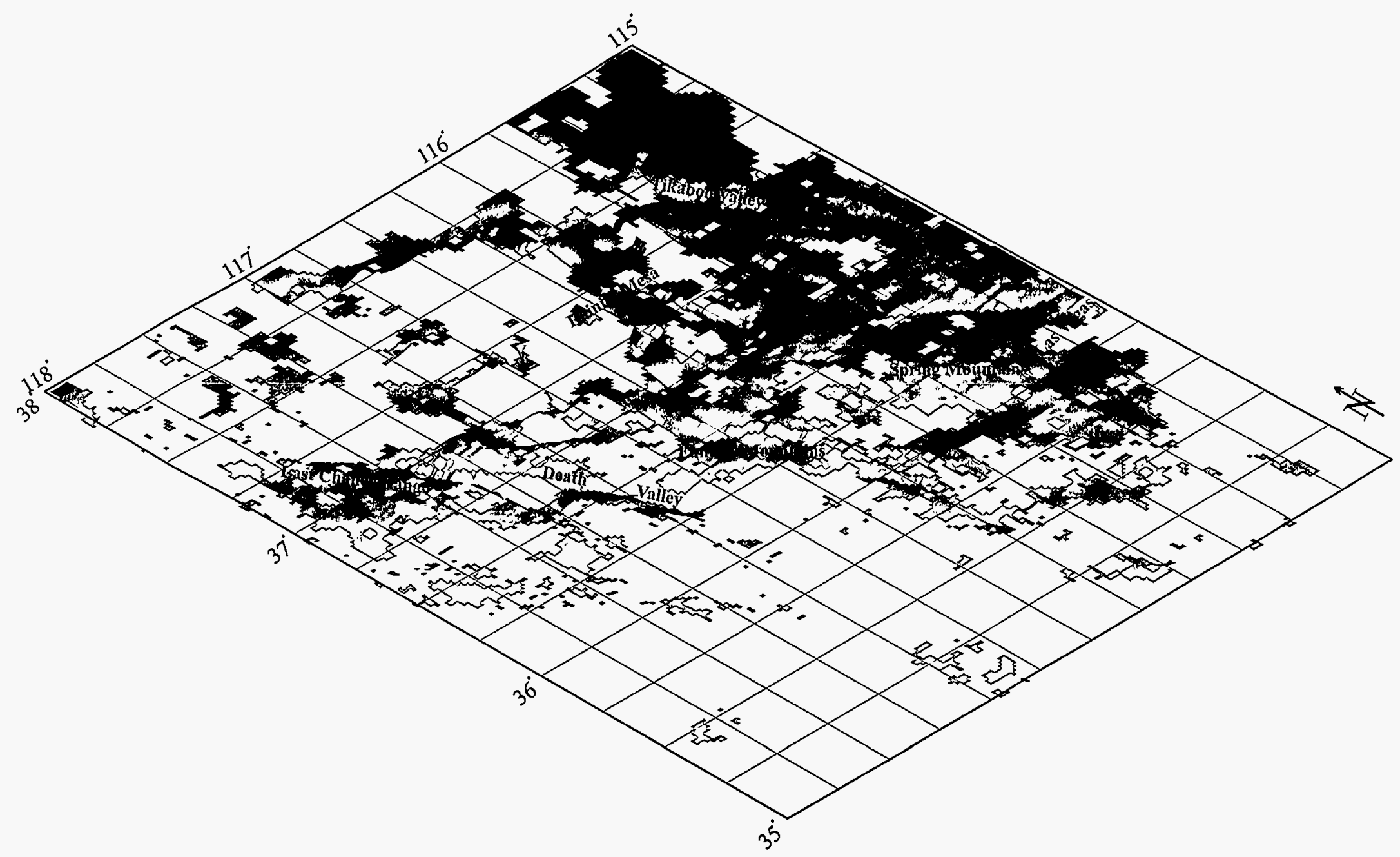

Figure 19. Perspective view of $2.5 \mathrm{D}$ surface of carbonate aquifer (P2). 

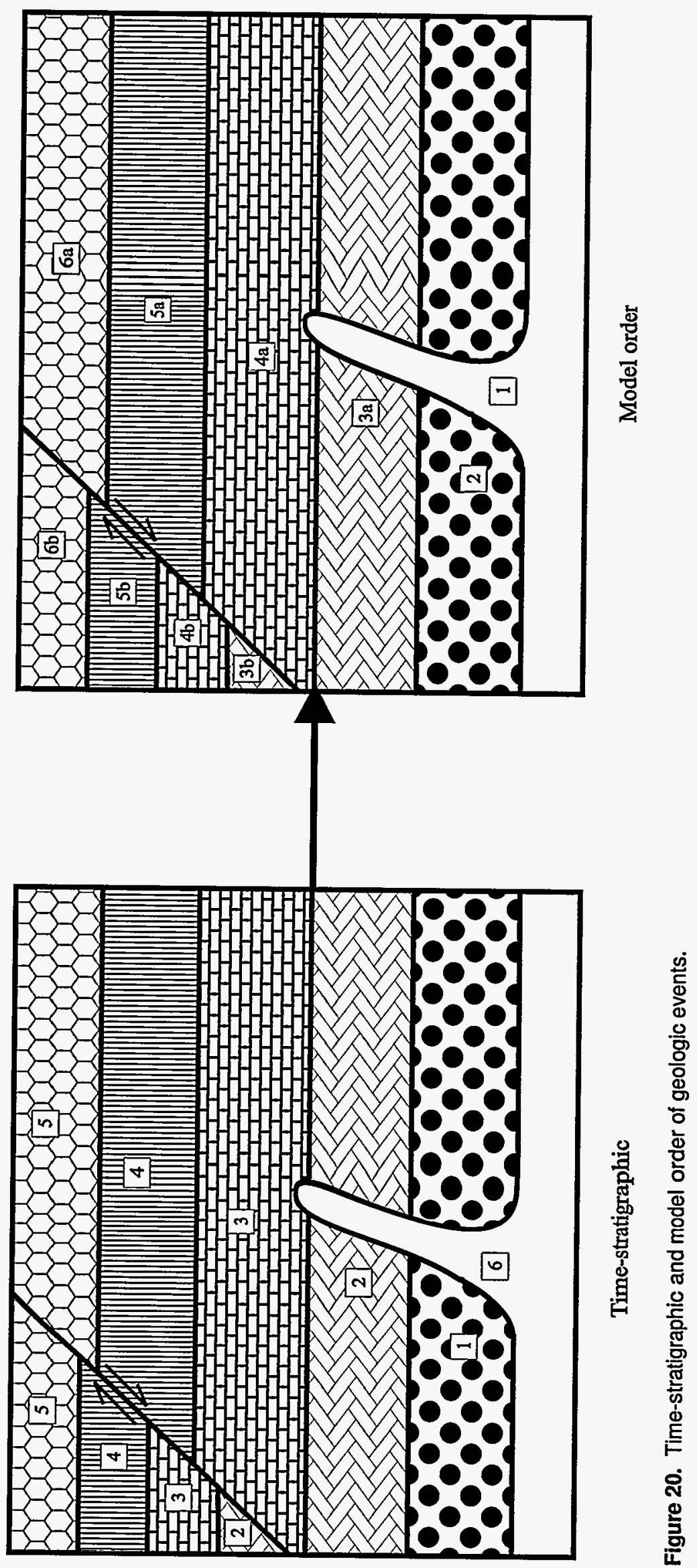


\section{Application of 3D Framework Model}

\section{Attribution of Model Cells}

The SGM software allows each cell to have multiple attributes. The software automatically assigned basic attributes to each cell to define its row, column, sequence, layer, depth, and altitude. The cells were further attributed to define their hydrogeologic units and faulting conditions.

Although fault traces less than $5 \mathrm{~km}$ in length were not used to construct the model, faults with shorter traces were used to help attribute the model. Fault traces that have lengths greater than $1.5 \mathrm{~km}$ influence ground-water flow at relatively shallow depths. Cells in the 3D SGM model with depths of less than $1,000 \mathrm{~m}$, through which these fault traces passed, were coded to indicate the presence of these faults.

The major faults found necessary to define the structural surfaces potentially affect ground-water flows to greater depths by providing deep-seated structural controls. Cells lying between depths of 1,000 and $5,000 \mathrm{~m}$, through which these major fault traces passed, were coded to indicate the presence of these faults. Below 5,000 m deep, confining pressures were assumed to keep the faults closed.

\section{Evaluating the 3D Model}

Once the 3D framework model was constructed, it was evaluated. The model was sliced vertically along the grid cells corresponding to the traces of the input cross sections. These slices were then displayed and could be rotated and viewed from any desired orientation (fig. 21). The displays along these cross sections represent the contents of the $3 \mathrm{D}$ geocellular model, and refiect all of the processing steps. Comparing them with the original input sections provided a suitable method of evaluating the fidelity of the model representation. Reasonably good agreement between the original sections and the model sections was found. The model sections retain the basic lithology and geometrical characteristics needed by the numerical ground-water flow modeling, but usually did not include minor features. Discrepancies occurred mainly where units were thin and undulating.

Discrepancies can also be seen on the model surface. The SGM clipping algorithm tends to extrapolate grids one grid cell further than necessary at onlapping edges. This results in a larger surface distribution of the shallow alluvial units that tend to extend too far up the hill slopes. The effect is enhanced because of the fairly coarse $(1,500 \mathrm{~m})$ grid cell dimensions. Because these extended surfaces are thin, no significant error is introduced into the assessment of hydraulic properties.

\section{Examination of the 3D Digital Hydrogeologic Framework Model}

SGM was used to examine the 3D hydrogeologic framework model. The 3D model contains all the surfaces and enclosed volumes, which can be displayed together in a variety of ways. For example, arbitrary cross sections or fence diagrams were constructed through the model and displayed. These fence diagrams were helpful in examining the 3D distribution of units and/or properties.

The model can be viewed from any desired perspective as a block diagram. The model can be thoroughly examined by rotating or by changing the angle of view. Numerous features that are not apparent from $2 \mathrm{D}$ representations become visible when looking at a 3D model. For example, numerous faulted blocks in Death Valley were evident from examination of the SGM model. Careful examination of these fault blocks revealed that they coincide with discharge features. The extent of aquifers and confining units, and the basement configuration, can be viewed independently or in combination. Layers or hydrogeologic units can be peeled off to reveal stratigraphically deeper units. Because the peel feature enabled the internal and external shapes of subsurface features of aquifers and confining units to be clearly seen, it was particularly significant. This capability produced views of rock units in the subsurface that were both visually revealing and interpretively significant. In addition, these views aided in developing the conceptual model of the flow system.

\section{Defining the 3D Distribution of Hydraulic Properties}

For ground-water flow modeling purposes, the hydrogeologic framework model included hydraulic conductivity values. Bedinger and others (1989b) developed a series of curves defining the distribution of hydraulic conductivity for all hydrogeologic units in the region. These hydraulic conductivity values describe the variation of rock properties by depth and 


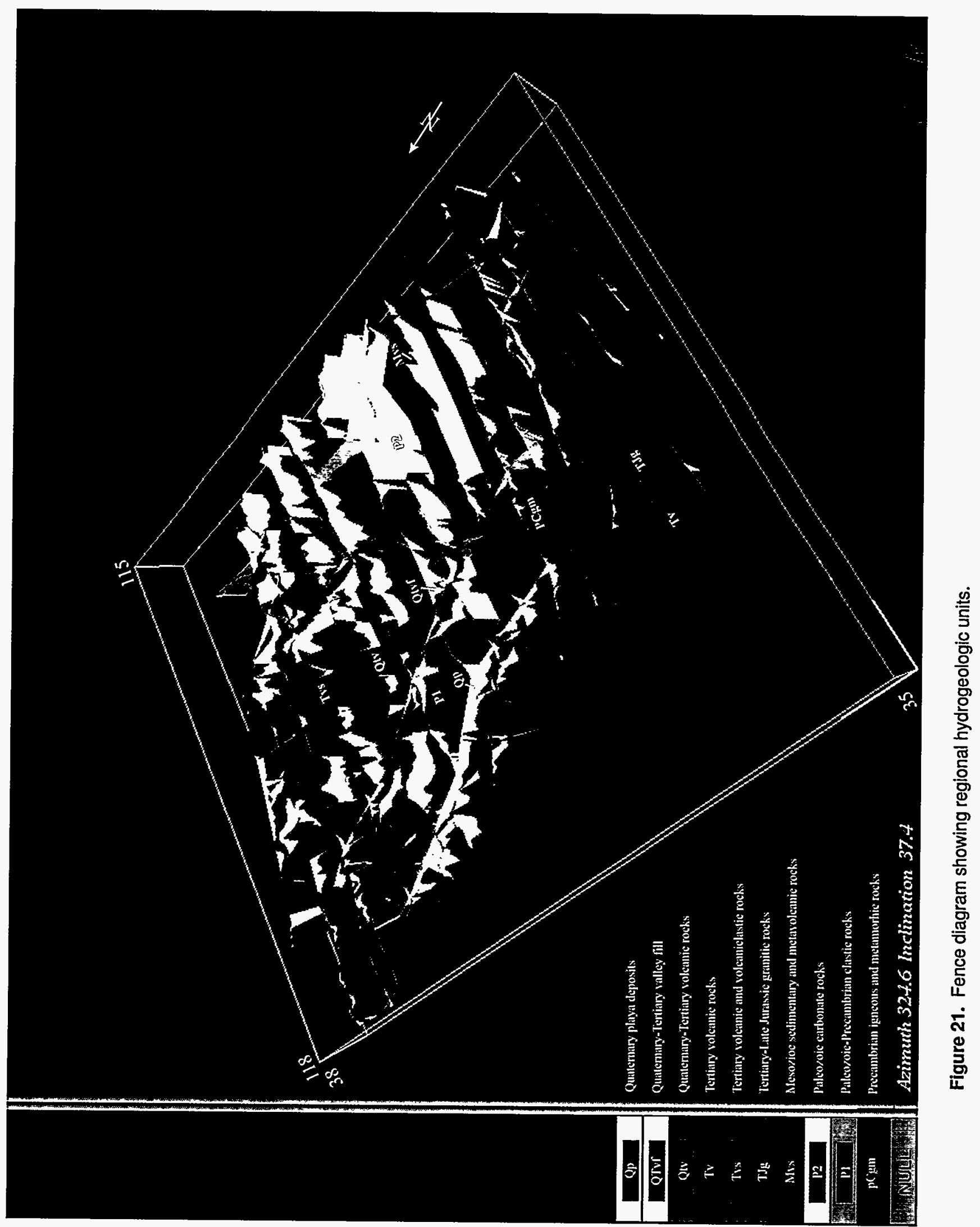


The existing cell attributes and estimated hydraulic conductivity values were used to formulate a series of Boolean algebraic expressions within the SGM software. These expressions produced a new attribute defining the estimated mean hydraulic conductivity value for each cell in the 3D hydrogeologic framework model. Because the hydraulic-conductivity values extended over ten orders of magnitude, a second attribute, the log-transformed value of the hydraulic conductivity, was computed for each cell.

\section{CHARACTERIZATION OF REGIONAL HYDROLOGIC CONDITIONS}

\section{Characterizing the Discharge Component}

The Death Valley saltpan has long been recognized as the ultimate discharge area for the Death Valley regional ground-water flow system. Intermediate discharge locations reflect topographic, geomorphic, stratigraphic, or structural controls; many involve combinations of these controls. The largest discharges from the regional ground-water flow system include springs, ET by phreatophytes and wet playas, and ground-water pumpage.

In this desert region, the demand for water by plants is so high that most previous investigators have concluded that only a small percentage of the water discharged from springs or applied to fields for irrigation is returned to the ground-water system (Waddell, 1982). Therefore, ET by plants and evaporative losses from wet playa surfaces account for the greatest volume of water discharged from the ground-water system (Fiero and others, 1974). ET estimates usually include some spring discharges, surface-water runoff, and irrigation return-flow waters. Because ET and bare-soil evaporative rates have not been precisely determined for this region, the estimated values for ET fluxes are inherently uncertain, and smaller contributing volumes of surface-water runoff and irrigation return-flow water are ignored by this study.

\section{Methods of Characterizing Discharge}

Most previous studies of ground-water resources in the Death Valley region have estimated ground-water discharge by delineating areas of phreatophytes on airphotos and applying empirically derived mean consumptive-use rates for those species of phreatophytes at the discharge site (Walker and Eakin, 1963; Rush, 1968; Malmberg and Eakin, 1962; Glancy, 1968; Malmberg, 1967). Although delineation of areas of phreatophytes is a useful method of ET estimation, this study utilizes detailed maps of specific phreatophytes. In areas where large regional springs occur, an estimated total volume of spring discharge was utilized as the net ground-water discharge for each area (Pistrang and Kunkel, 1964). Except in basins where pumpage accounts for a large percentage of the water budget, such as Pahrump Valley (Harrill, 1986), most of the previous water-resource studies have ignored ground-water pumpage.

\section{Characterization and Estimation of Evapotranspiration Volumes}

Evapotranspiration rates have not been precisely determined for plant communities and bare soil conditions in most of the region. Therefore, detailed maps of potential ET areas were developed. Waterconsumption rates developed for similar nearby areas were applied to compute discharge rates.

\section{Evapotranspiration Areas}

Areas where ground water is found at shallow depths are potentially significant discharge zones. Such zones can be identified by shallow water depths, the presence of moist soil conditions, and certain vegetative communities. Four data sets were combined to identify such areas: vegetation type, vegetation density, soil classes, and locations of springs. A map of potential ET was developed by combining the high-density phreatophytes, salt bush, bare soil, and unclassified regions classes of the vegetation map with locations of regional spring discharges and high-salinity soil areas (D'Agnese and others, 1996). Where bare soils are coincident with high salinity areas, evaporation occurs through discharging or wet playas. Unclassified areas on the vegetation map include additional phreatophyte or saltpan areas that could not be grouped into the other classes.

The potential ET map represents conditions as of the mid-1980's and includes all areas in the Death Valley region where significant ET volumes may occur from phreatophyte vegetation or moist bare soil. Field verification of each delineated potential discharge zone resulted in a refined final ET map 
containing six ET classes: wetlands, hardwood phreatophytes, herbaceous phreatophytes, saltbush flats, wet playas, and mixed phreatophyte areas (fig. 23). Wetlands occur near discharging springs and include areas of standing water, reeds, rushes, sedges, and other wetland grasses. Where low-salinity ground water occurs at shallow depths or where fresh water is present in large quantities as a result of regional spring discharge, hardwood phreatophytes are dominant. At the edges of wet playas, or in areas with shallow water tables, herbaceous phreatophytes dominate. The herbaceous phreatophytes include high salinity species such as pickleweed, saltgrass, and rabbitbrush. Saltbush flats occur on alluvial flats surrounding wet playas and are dominated by greasewood and saltbush. Because species of the saltbush possess root systems capable of growth to depths of $15 \mathrm{~m}$, their presence may indicate ET of relatively deep ground water. Wet playas and alkali flats are included within the bare soil areas class. In these areas, the capillary fringe extends to within a few inches of the land surface and the soil texture becomes fluffy. These large pore spaces disrupt capillary action. A fluffy texture may indicate that water has moved upward through the playa deposits and precipitated dissolved salt during evaporation (Glancy, 1968). The mixed phreatophytes class includes areas containing such heterogenous mixtures of the above classes that classification into any one class is difficult.

\section{Evapotranspiration Rates and Flux Estimation}

Water-consumption rates for each map class were required to estimate ET fluxes. Precise data for each class were unavailable, so estimated annual rates of water-consumption were obtained from the results of previous investigations in the Death Valley region (Robinson, 1958; Malmberg and Eakin, 1962; Walker and Eakin, 1963; Malmberg, 1967; Rush, 1968; Czarnecki, 1990; Duell, 1990). These rates were multiplied by the area of each class to obtain estimated volumes of ground-water discharge due to ET (table 2).

Generally, the discharge estimates developed by this study are slightly larger than those used in previous investigations. The reasons for these differences are:

1. Some of the discharge areas in this study have never before been defined as regional ET areas;
2. Some areas included in this study have previously been considered to contribute negligible amounts of discharge; and

3. Some areas identified in this study include areas of phreatophytes that had not been identified and mapped by previous studies.

\section{Spring Discharge Accounting}

Numerous springs in the region occur as small discharges in many of the mountain ranges. This spring water is from nearby sources, and the locations of these springs are controlled by permeability variations in the rocks and water levels related to landsurface altitude, which cause the water to discharge at the surface (Prudic and others, 1993). These springs, which have small (less than $25 \mathrm{~m}^{3} / \mathrm{d}$ ) to moderate yields ( 25 to more than $2,200 \mathrm{~m}^{3} / \mathrm{d}$ ), commonly represent perched or semiperched, local ground-water flow systems associated with regional recharge areas. These springs commonly emerge from consolidated rock within the mountains or ridges flanking valleys and are characterized by highly variable discharge rates and by variable temperature, usually less than $21^{\circ} \mathrm{C}$ (Winograd and Thordarson, 1975).

Springs that discharge from the regional ground-water flow system are not included in this group of springs. Regional springs typically emerge from the valley fill and the carbonate aquifer at low altitudes along the borders or on the floor of some valleys (Winograd and Thordarson, 1975). The locations of these springs are a result of:

1. An intersection of the land surface and the water table;

2. Large permeability faults or fractures which act as conduits, directing regional ground-water to the surface;

3. A stratigraphic contact of large permeability material with small permeability material, which forces flow paths to arc toward the land surface; or

4. A structural contact caused by the juxtaposition of large permeability material with small permeability material causing an abrupt change in ground-water flow paths (Pistrang and Kunkel, 1964).

These valley-level springs, here defined as regional springs, represent discharge points for a regional saturated zone; they are characterized by high and uniform discharge and uniform temperatures that range from $24^{\circ} \mathrm{C}$ to $35^{\circ} \mathrm{C}$ (Winograd and Thordarson, 1975). 


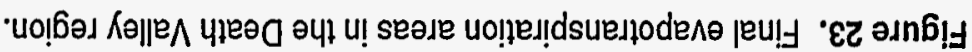

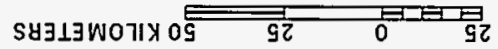
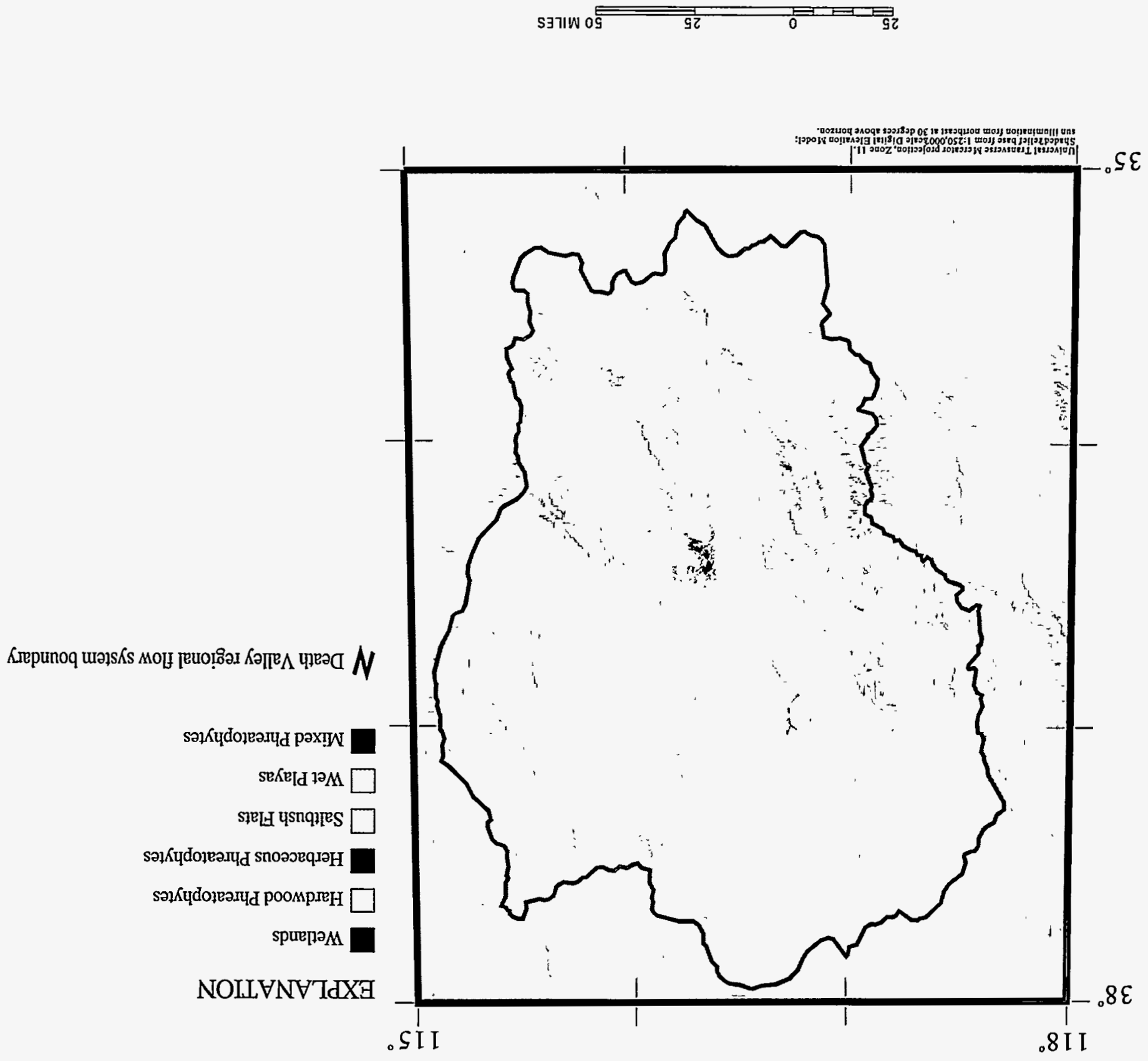
Table 2. Estimated evapotranspiration and spring discharge rates by discharge area

$\left[\mathrm{m}^{3} / \mathrm{d}\right.$, cubic meters per day]

\begin{tabular}{|c|c|c|c|}
\hline Discharge area & $\begin{array}{l}\text { Springs } \\
\left(\mathrm{m}^{3} / \mathrm{d}\right)\end{array}$ & $\begin{array}{c}\text { Evapotranspiration } \\
\left(\mathrm{m}^{3} / \mathrm{d}\right)\end{array}$ & $\begin{array}{c}\text { Discharge estimated } \\
\left(\mathrm{m}^{3} / \mathrm{d}\right)\end{array}$ \\
\hline Sand Springs/N. Death Valley & 100 & Unknown & ${ }^{1} 100$ \\
\hline Stonewall Flats East Playa & 0 & 300 & ${ }^{2} 300$ \\
\hline Stonewall Flats West Playa & 0 & 100 & ${ }^{2} 100$ \\
\hline Lida Junction Playa & 0 & 600 & ${ }^{2} 600$ \\
\hline Sarcobatus Flats Main Playa & 0 & 12,900 & ${ }^{2} 12,900$ \\
\hline Coyote Holes Playas & 0 & 200 & ${ }^{2} 200$ \\
\hline Oasis Valley & 3,100 & 14,500 & ${ }^{3,4}[4,500$ \\
\hline Bonnie Calire Playa & 0 & 400 & 2400 \\
\hline Grapevine Canyon & 3,600 & 2,900 & ${ }^{3,4} 5,000$ \\
\hline Mesquite Flat/Stovepipe Wells & Unknown & 38,100 & 238,100 \\
\hline Main Salt Pan & 3,000 & 100,000 & $2,5100,000$ \\
\hline Saratoga Springs & 700 & 33,200 & $3,533,200$ \\
\hline Furnace Creek Ranch & 11,100 & Unknown & ${ }^{1} 11,000$ \\
\hline Salt Creek Hills & Unknown & 3,800 & 23,800 \\
\hline Amargosa River & 0 & 1,500 & ${ }^{2} 1,500$ \\
\hline Peter's Playa-Amargosa Flats & 0 & 28,300 & ${ }^{2} 28,300$ \\
\hline Ash Meadows & 100,400 & 91,700 & $3,591,700$ \\
\hline Carson Slough & Unknown & 8,100 & ${ }^{3} 8,100$ \\
\hline Alkali Flat & Unknown & 17,200 & ${ }^{3} 17,200$ \\
\hline Indian/Cactus Springs & 4,100 & 2,400 & $3,44,500$ \\
\hline Stewart Valley Playa & 0 & 20,800 & ${ }^{2} 20,800$ \\
\hline Pahrump Valley & 0 & 18,000 & ${ }^{2} 18,000$ \\
\hline Shoshone/Tecopa & 1,000 & 24,200 & ${ }^{3} 24,200$ \\
\hline Chicago Valley & 0 & 8,700 & 28,700 \\
\hline South Chicago Valley & 1,400 & 4,800 & 34,800 \\
\hline California Valley & 0 & 1,300 & 21,300 \\
\hline China Ranch & Unknown & 2,500 & ${ }^{3} 2,500$ \\
\hline Tecopa Pass & Unknown & 1,800 & ${ }^{3} 1,800$ \\
\hline Sperry Hills (Amargosa Canyon) & Unknown & 6,000 & ${ }^{3} 6,000$ \\
\hline Mesquite Lake & 0 & 29,000 & 229,000 \\
\hline
\end{tabular}

'Dominantly spring.

${ }^{2}$ Dominantly ET.

${ }^{3}$ Combined spring and ET.

${ }^{4}$ Spring discharge is partially ( 50 percent) consumed as domestic water use and not recirculated.

${ }^{5}$ Spring discharge is recirculated and consumed as ET. 
Based on these criteria, the regional spring data set was modified and attributed with regional springdischarge rate and temperature data collected from several sources (Pistrang and Kunkel, 1964; Miller, 1977; Bedinger and others, 1984c; Langer and others, 1984; Bedinger and others, 1989a). The most recently measured rates (table 3 ) and temperatures were used. Occasionally, data were reported for springs that did not occur in the GSIS data base (fig. 24). These springs were added to the regional spring data set. Once completed, a summation of total spring discharge was developed (table 2).

\section{Ground-Water Pumpage}

To characterize the amount of human-induced water use in the basin, a data set of water-producing wells was developed. Estimates of water use for the Death Valley region have been reported on a somewhat discontinuous basis. These estimates are reported by use (commercial, irrigation, mining, domestic) for each hydrographic area (Nevada State Engineer, written commun., 1993). Unfortunately, such records do not exist for all of the hydrographic areas in the Death Valley region. Bedinger and others (1984a, b) have attempted to develop complete wateruse estimates for the entire region by averaging empirical rates of use based on well data contained in the USGS NWIS data base. Data from these reports, the USGS NWIS data base, and the Nevada State Engineer's Office were compiled and evaluated. Average annual consumptive water-use (total pumpage) values for each hydrographic area were estimated and reported in table 4. These rates, however, must be reduced by a percentage to get a net pumping draft. Also, pumpage varies from year to year so some adjustment is needed to get a single rate for use in the steady-state simulation. To account for these factors pumpage rates were reduced by a factor of 50 percent to calculate an overall average annual rate. Although these average rates are based on different time periods and different years, they offer the best available estimate of annual pumping over historical time.
Table 3. Reported regional spring data for Death Valley region $\left[\mathrm{m}^{3} / \mathrm{d}\right.$, cubic meters per day; $\mathrm{NA}$, not available $]$

\begin{tabular}{|c|c|}
\hline Spring & $\begin{array}{c}\text { Discharge } \\
\left(\mathrm{m}^{3} / \mathrm{d}\right)\end{array}$ \\
\hline Grapevine Springs ${ }^{\top}$ & 2,452 \\
\hline Staininger Spring ${ }^{3}$ & 1,090 \\
\hline Surprise Springs ${ }^{4}$ & 27 \\
\hline Sand Spring 4 & 2 \\
\hline Saratoga Springs' & 684 \\
\hline Amargosa Narrows Spring ${ }^{2}$ & 544 \\
\hline Landing Strip ${ }^{2}$ & 136 \\
\hline Beatty Valley $\# 2^{2}$ & 544 \\
\hline Beatty Valley $\# 1^{2}$ & 544 \\
\hline N. Oasis Valley Spring ${ }^{2}$ & 273 \\
\hline S. Oasis Valley Spring ${ }^{2}$ & 82 \\
\hline Springdale Springs ${ }^{2}$ & 136 \\
\hline Oasis Valley Hills ${ }^{2}$ & 55 \\
\hline E. Oasis Valley Hill ${ }^{2}$ & 343 \\
\hline Indian Springs ${ }^{1}$ & 4,049 \\
\hline Keane Wonder Spring ${ }^{I}$ & 164 \\
\hline Nevares Springs ${ }^{1}$ & 1,908 \\
\hline Cow Creek Springs ${ }^{1}$ & 1,200 \\
\hline Salt Springs ${ }^{5}$ & 25 \\
\hline Texas Spring & 1,145 \\
\hline Travertine Springs ${ }^{1}$ & 6,486 \\
\hline Navel Springs & NA \\
\hline Tecopa Hot Springs' & 491 \\
\hline Chappo Spring ${ }^{\prime}$ & 547 \\
\hline Fairbanks Springs ${ }^{2}$ & 17,960 \\
\hline Rogers Springs 1 & 431 \\
\hline Longstreet Springs ${ }^{2}$ & 10,743 \\
\hline Crystal Pool $^{1}$ & 17,933 \\
\hline Devil's Hole Area $^{2}$ & 856 \\
\hline Point of Rocks \#1 ${ }^{2}$ & 2,164 \\
\hline Point of Rocks $\# 2^{2}$ & 164 \\
\hline Point of Rocks $\# 4^{2}$ & 3,080 \\
\hline Point of Rocks $\# 3^{2}$ & 60 \\
\hline Point of Rocks $\# 5^{2}$ & 8,177 \\
\hline Point of Rocks \# $6^{2}$ & 8,166 \\
\hline Jack Rabbit Spring & 3,200 \\
\hline Big Spring ${ }^{1}$ & 5,646 \\
\hline Bole Spring ${ }^{2}$ & 4,807 \\
\hline Last Chance Spring ${ }^{2}$ & 8,176 \\
\hline Grapevine Springs $^{2}$ & 8,846 \\
\hline $\begin{array}{l}{ }^{1} \text { Bedinger and others (1989c) } \\
{ }^{2} \text { Bedinger and others (1984c) } \\
{ }^{3} \text { Langer and others (1984) } \\
{ }^{4} \text { Miller (1977) } \\
{ }^{5} \text { Pistrang and Kunkel (1964) }\end{array}$ & \\
\hline
\end{tabular}




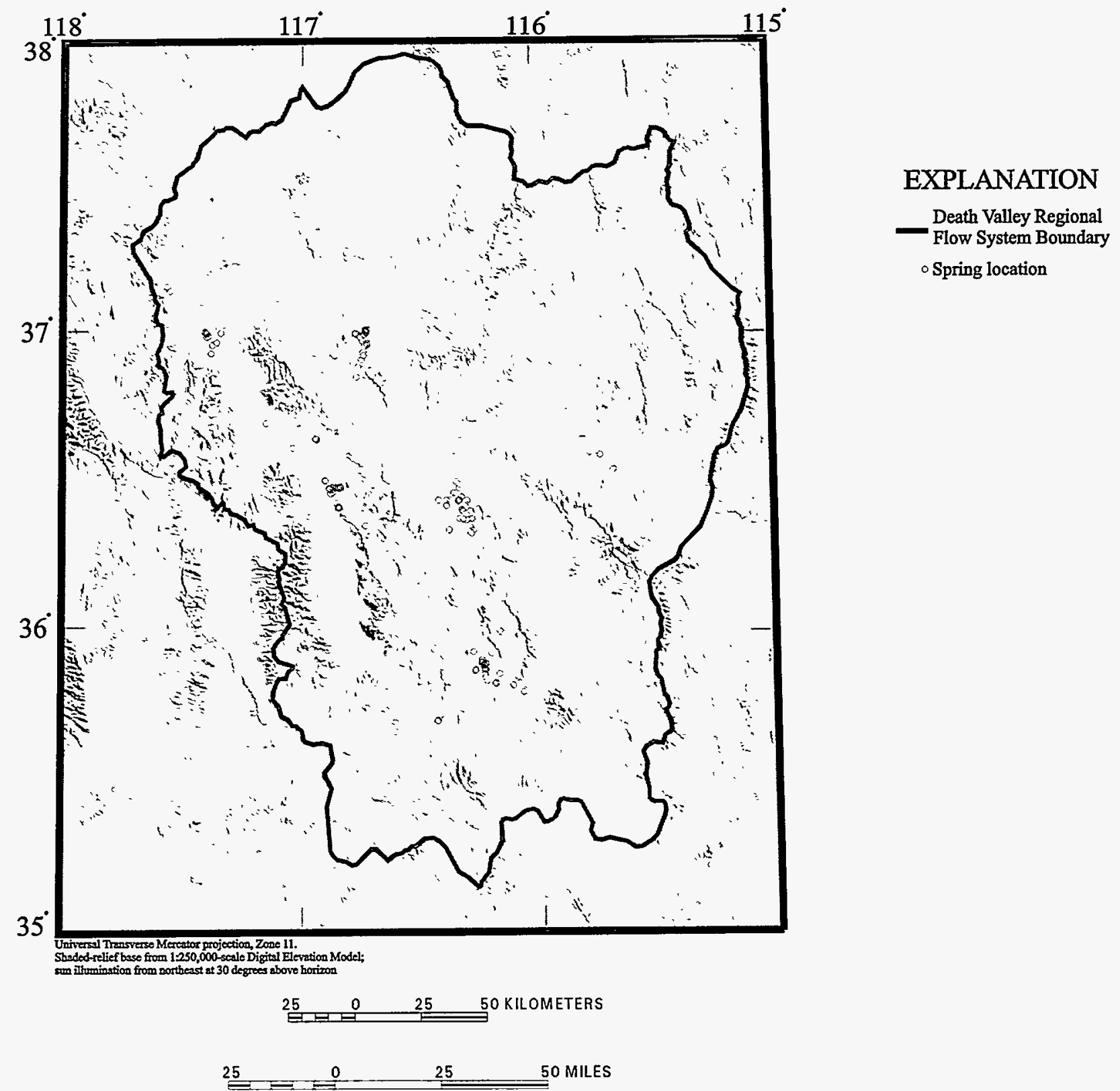

Figure 24. Locations of regional springs. 
Table 4. Water-use estimates for selected hydrographic areas

$\left[\mathrm{m}^{3} / \mathrm{d}\right.$, cubic meters per day; $<$, less than]

\begin{tabular}{|c|c|c|c|c|}
\hline $\begin{array}{l}\text { Hydrographic } \\
\text { area number }^{1}\end{array}$ & Hydrographic area & Year & $\begin{array}{l}\text { Total } \\
\left(\mathrm{m}^{3} / \mathrm{d}\right)\end{array}$ & Source \\
\hline 144 & Lida Valley & 1975 & $<3,380$ & Bedinger and others, 1984a \\
\hline 146 & Sarcobatus Flat & 1975 & $<3,380$ & Bedinger and others, $1984 \mathrm{a}$ \\
\hline 159 & Yucca Flat & 1975 & $<3,380$ & Bedinger and others, $1984 \mathrm{a}$ \\
\hline \multirow[t]{9}{*}{161} & Indian Springs Valley & 1975 & 3,379 & Bedinger and others, 1984a \\
\hline & & 1984 & 2,093 & Nevada State Engineer, 1993 \\
\hline & & 1985 & 2,294 & Nevada State Engineer, 1993 \\
\hline & & 1986 & 2,792 & Nevada State Engineer, 1993 \\
\hline & & 1987 & 2,456 & Nevada State Engineer, 1993 \\
\hline & & 1988 & 1,933 & Nevada State Engineer, 1993 \\
\hline & & 1989 & 2,102 & Nevada State Engineer, 1993 \\
\hline & & 1991 & 1,728 & Nevada State Engineer, 1993 \\
\hline & & 1992 & 2,237 & Nevada State Engineer, 1993 \\
\hline \multirow[t]{27}{*}{162} & Pahrump Valley & 1962 & 98,663 & Nevada State Engineer, 1993 \\
\hline & & 1963 & 107,882 & Nevada State Engineer, 1993 \\
\hline & & 1964 & 126,730 & Harrill, 1986 \\
\hline & & 1965 & 123,350 & Harrill, 1986 \\
\hline & & 1966 & 128,791 & Nevada State Engineer, 1993 \\
\hline & & 1967 & 140,251 & Nevada State Engineer, 1993 \\
\hline & & 1968 & 162,043 & Nevada State Engineer, 1993 \\
\hline & & 1969 & 138,220 & Harrill, 1986 \\
\hline & & 1970 & 144,032 & Nevada State Engineer, 1993 \\
\hline & & 1971 & 128,362 & Nevada State Engineer, 1993 \\
\hline & & 1972 & 123,894 & Nevada State Engineer, 1993 \\
\hline & & 1973 & 133,119 & Nevada State Engineer, 1993 \\
\hline & & 1974 & 139,867 & Nevada State Engineer, 1993 \\
\hline & & 1975 & 137,702 & Nevada State Engineer, 1993 \\
\hline & & 1976 & 150,382 & Nevada State Engineer, 1993 \\
\hline & & 1977 & 145,011 & Nevada State Engineer, 1993 \\
\hline & & 1978 & 116,033 & Nevada State Engineer, 1993 \\
\hline & & 1983 & 78,245 & Nevada State Engineer, 1993 \\
\hline & & 1984 & 82,293 & Nevada State Engineer, 1993 \\
\hline & & 1985 & 77,907 & Nevada State Engineer, 1993 \\
\hline & & 1986 & 65,588 & Nevada State Engineer, 1993 \\
\hline & & 1987 & 64,704 & Nevada State Engineer, 1993 \\
\hline & & 1988 & 66,386 & Nevada State Engineer, 1993 \\
\hline & & 1989 & 68,035 & Nevada State Engineer, 1993 \\
\hline & & 1990 & 70,741 & Nevada State Engineer, 1993 \\
\hline & & 1991 & 83,966 & Nevada State Engineer, 1993 \\
\hline & & 1992 & 78,704 & Nevada State Engineer, 1993 \\
\hline \multirow[t]{7}{*}{163} & Mesquite Valley & 1975 & $<3,380$ & Bedinger and others, 1984a \\
\hline & & 1983 & 1,786 & Nevada State Engineer, 1993 \\
\hline & & 1984 & 1,245 & Nevada State Engineer, 1993 \\
\hline & & 1985 & 879 & Nevada State Engineer, 1993 \\
\hline & & 1986 & 1,328 & Nevada State Engineer, 1993 \\
\hline & & 1987 & 1,302 & Nevada State Engineer, 1993 \\
\hline & & 1988 & 1,487 & Nevada State Engineer, 1993 \\
\hline
\end{tabular}


Table 4. Water-use estimates for selected hydrographic areas-Continued

\begin{tabular}{|c|c|c|c|c|}
\hline $\begin{array}{l}\text { Hydrographic } \\
\text { area number }\end{array}$ & Hydrographic area & Year & $\begin{array}{l}\text { Total } \\
\left(\mathrm{m}^{3} / \mathrm{d}\right)\end{array}$ & Source \\
\hline & & 1989 & 1,606 & Nevada State Engineer, 1993 \\
\hline & & 1990 & 1,606 & Nevada State Engineer, 1993 \\
\hline & & 1991 & 649 & Nevada State Engineer, 1993 \\
\hline & & 1992 & 778 & Nevada State Engineer, 1993 \\
\hline $225 / 226$ & Mercury/Rock Valley & 1975 & $<3,380$ & Bedinger and others, $1984 \mathrm{a}$ \\
\hline 228 & Oasis Valley & 1975 & $<3,380$ & Bedinger and others, 1984a \\
\hline \multirow[t]{11}{*}{230} & Amargosa Valley & 1967 & 31,561 & Nevada State Engineer, 1993 \\
\hline & & 1968 & 30,550 & Nevada State Engineer, 1993 \\
\hline & & 1973 & 24,373 & Nevada State Engineer, 1993 \\
\hline & & 1985 & 31,910 & Nevada State Engineer, 1993 \\
\hline & & 1986 & 24,460 & Nevada State Engineer, 1993 \\
\hline & & 1987 & 20,740 & Nevada State Engineer, 1993 \\
\hline & & 1988 & 13,886 & Nevada State Engineer, 1993 \\
\hline & & 1989 & 13,250 & Nevada State Engineer, 1993 \\
\hline & & 1990 & 26,384 & Nevada State Engineer, 1993 \\
\hline & & 1991 & 20,098 & Nevada State Engineer, 1993 \\
\hline & & 1992 & 27,588 & Nevada State Engineer, 1993 \\
\hline $240 / 241$ & California/Chicago Valley & 1975 & $<3,380$ & Bedinger and others, $1984 \mathrm{~b}$ \\
\hline 242 & Lower Amargosa Valley & 1962 & 10,476 & Bedinger and others, $1984 \mathrm{~b}$ \\
\hline $243 / 244 / 245$ & Death Valley & 1975 & $<3,380$ & Bedinger and others, $1984 \mathrm{~b}$ \\
\hline
\end{tabular}

${ }^{1}$ Water use estimates are not available for hydrographic areas 145, 147, 148, 157, 158, 160, 168, 169, 211, 227, and 229.

Once the average annual consumptive water-use estimates were determined for each hydrographic area, individual rates were assigned to each well located on the map of water-producing wells. Each well was assigned a dominant use: commercial, municipal, domestic, industrial, or agricultural. For each use, the estimated consumptive use rates for each hydrographic area were equally apportioned among the wells located within the area and designated with the appropriate dominant use. For example, four municipal wells were reported in the Amargosa Valley and the estimated municipal water use for this area averaged $351 \mathrm{~m}^{3} / \mathrm{d}$. Therefore, each municipal water well was assigned $87.75 \mathrm{~m}^{3} / \mathrm{d}$ of water use. This method was used to assign discharge values for all wells in the data base.

\section{Characterizing the Recharge Component}

The major source of recharge to the regional ground-water flow system is from precipitation on the highest mountains within the region. The regional flow system is also recharged by interbasinal flow. Some recharge also results from recycled irrigation and domestic waters, as well as seepage of spring discharge back into the ground-water system (Rice, 1984). These recycled components are considered to be small compared to regional infiltration and interbasinal flux volumes and are neglected (Waddell, 1982, p. 14).

\section{Previous Methods of Characterizing Recharge}

Empirical, water-balance, and distributedparameter methods have been used to characterize the 
location and amount of regional recharge in the Death Valley region. Each method attempts to characterize the complex array of factors controlling recharge; each has limitations.

An empirical precipitation-recharge relation was developed by Maxey and Eakin (1949) from water mass-balance estimates for basins in southern and eastern Nevada. They suggest that the annual precipitation amount and the percentage of precipitation that becomes ground-water recharge increases with increasing altitude. Depending on the valley, Maxey and Eakin assumed that no recharge occurs where mean annual precipitation is less than about $200 \mathrm{~mm}$, or altitude is lower than $1,524 \mathrm{~m}$. Above $1,524 \mathrm{~m}$ in altitude, they assigned an increasing percentage of precipitation that was assumed to become recharge to a ranked series of $305-\mathrm{m}$ altitude intervals (table 5).

Table 5. Area-altitude classes

[Datum is sea level; >, greater than; <, less than; modified from Maxey and Eakin (1949)]

\begin{tabular}{cc}
\hline $\begin{array}{c}\text { Area-altitude class } \\
\text { (meters) }\end{array}$ & $\begin{array}{c}\text { Precipitation that } \\
\text { becomes recharge } \\
\text { (percent) }\end{array}$ \\
\hline$>2,438$ & 25 \\
$2,134-2,438$ & 15 \\
$1,829-2,134$ & 7 \\
$1,524-1,829$ & 3 \\
$<1,524$ & 0 \\
\hline
\end{tabular}

Other investigators, working in the Great Basin, developed similar area-altitude relations for their studies (Walker and Eakin, 1963; Miller, 1977; Malmberg and Eakin, 1962; Malmberg, 1967; Winograd and Thordarson, 1975; Harrill, 1986). Each investigator noted that the method was completely empirical and ignored differences in lithology, soils, climate, vegetation, and topographic factors such as exposure, aspect, and slope.

Rice (1984) developed a relatively detailed recharge calculation as part of a regional modeling study. Rice employed a water-balance method that utilized average annual precipitation distributions derived from Quiring's (1965) regressions and potential ET estimates developed from empirical methods. These computations showed that recharge occurs if the altitude is greater than $1,675 \mathrm{~m}$ and the annual precipitation is greater than $254 \mathrm{~mm}$. Because these two criteria meet the plant requirements of pinyon pine and juniper, Rice placed the area of recharge to coincide with that plant zone and plant zones of higher altitude and moisture. More recent investigations by West (1989) have placed the lower altitude limits of regional recharge at the Mixed Shrub-Transition Zone where blackbrush flourishes. West noted that these communities represent the altitudinal zone at which winter recharge of soil moisture is normally balanced by summer ET loss. Therefore, in wet years some regional recharge may occur in these areas.

Rice's water-balance method has several significant limitations. Rice (1984) suggested that:

1. The recharge calculations are at too gross a scale to compute small amounts of recharge, such as the amount that probably occurs on Yucca Mountain;

2. The method depends only on temperature and an empirical crop coefficient to calculate ET rates that are influenced by numerous climatic conditions; and

3. This method averages rainfall events into monthly distributions and does not account for highintensity storms and runoff events which are common to the area and may significantly contribute to recharge.

Because the error associated with each component of the water-balance equation may be larger than the net total recharge calculated for many arid basins, waterbalance methods are of limited usefulness.

Recent investigators have attempted to use distributed-parameter precipitation-runoff models to estimate ground-water recharge in several hydrographic basins of the Death Valley region (Lichty and McKinley, 1995). These models attempt to simulate the processes in the soil-plant-atmosphere system through a series of integrated modules. For basins that contain both a surface-water and groundwater component, monthly or storm-based waterbalance simulations may be modeled. Although successful simulations have been conducted using these models for various regions of the United States (Leavesley and others, 1983), the use of such models in extremely arid environments where little surfacewater exists, has proven to be difficult (Lichty and McKinley, 1995). 


\section{Limitations of the Empirical Maxey-Eakin Method}

Despite the empirical nature of the MaxeyEakin method, it still remains the most widely-used means of estimating regional ground-water recharge in the Great Basin. Therefore, the Maxey-Eakin method was employed to develop a preliminary map of potential recharge areas using digital altitude data and a digital representation of average annual precipitation data (J.A. Hevesi, U.S. Geological Survey, written commun., 1995). To assess the accuracy of the predicted recharge areas, the map was visually displayed and compared to maps showing lowtemperature (local) spring locations and vegetation classes. The local springs are believed to represent discharges of locally recharged ground-water. The selected vegetation classes reflect moisture at shallow depths. Careful comparison of these three maps showed that the Maxey-Eakin method failed to identify some lower altitude areas where long-term recharge appeared likely from the pattern of spring locations and vegetation, and also included some higher altitude areas where long-term recharge may not occur. Because the Death Valley regional groundwater flow system is compartmentalized, any under- or over-estimation of recharge volumes may result in discrepancies in interbasinal transfers.

Miller (1977) experienced similar problems when using the Maxey-Eakin method for a study of the ground-water resources of Death Valley National Park. Miller (1977) attributed the discrepancies to many factors that can be summarized as follows:

1. The method was originally developed for basins that were believed to be unaffected by interbasinal flow.

2. Drainage of mountain slopes are influenced by aspect controls that affect ET rates and soil moisture that ultimately control recharge. North and east facing slopes are typically cooler and wetter, while south and west facing slopes are warmer and drier. Therefore, more recharge will probably occur in north and east facing slopes, and less will occur on south and west facing slopes. However, the Maxey-Eakin method does not take this phenomenon into account.

3. Uncertainties in the estimates of discharge rates, which are used to calculate recharge rates, may contribute to volummetric discrepancies.

4. High altitudes (in excess of $3,000 \mathrm{~m}$ ) may contribute significantly more recharge than the
25 percent of precipitation predicted by the Maxey-Eakin method.

5. Altitude-percentage constants used in the MaxeyEakin method may need to be adjusted on a basin-by-basin basis to account for factors such as lithology, aspect, and vegetation.

6. The Maxey-Eakin method assumes that recharge does not occur below 1,524 m, but the presence of dense vegetation and cold springs at lower altitudes indicate that significant infiltration occurs in these areas at steady-state.

7. The Maxey-Eakin method is extremely dependent on the prediction of average annual precipitation which is poorly understood and quantified; therefore, a more accurate characterization of precipitation may lead to more accurate recharge estimates if the recharge coefficients are likewise revised.

8. The Maxey-Eakin method and its variants are simplistic and should be modified to consider critical factors such as rock type, permeability of weathered rock and soil, permeability of stream channel deposits, soil moisture at the time of precipitation and slope.

\section{Modifying the Maxey-Eakin Method}

The Maxey-Eakin method was adapted to make it more sensitive to the critical factors affecting recharge by using potential recharge indicators existing within the GSIS data base. Four potential recharge indicators were used: (1) altitude, (2) slopeaspect, (3) relative rock and soil permeability, and (4) vegetation. In each case, appropriate map categories were reclassified to represent the recharge potential on a six-point scale. In each case, a value of zero indicated no recharge potential, a value of one represented low recharge potential, and a value of five represented high recharge potential.

As described by Maxey and Eakin (1949), altitude significantly affects recharge. As altitude increases precipitation increases along with the potential for recharge. The digital terrain model was reclassified according to the ratings shown in table 6 to produce a map describing recharge potential based on altitude. 
Table 6. Potential recharge classification for altitude zones

[Datum is sea level; $>$, greater than; $<$, less than]

\begin{tabular}{cc}
\hline $\begin{array}{c}\text { Altitude zone } \\
\text { (meters) }\end{array}$ & Recharge rating \\
\hline$>2,743$ & 5 \\
$2,438-2,743$ & 4 \\
$2,134-2,438$ & 3 \\
$1,829-2,134$ & 2 \\
$1,524-1,829$ & 1 \\
$<1,524$ & 0 \\
\hline
\end{tabular}

The vegetation-landform map was reclassified in a similar manner. Because the mixed shrubtransition zone is believed to be the lowest vegetation zone to experience any long-term recharge flux, those vegetation classes that reflect these soil moisture conditions and wetter were ranked according to the values shown in table 7 . Therefore, a vegetationbased recharge potential map was developed.

Table 7. Potential recharge classification for vegetation zones

\begin{tabular}{lc}
\hline \multicolumn{1}{c}{ Vegetation zone } & Recharge rating \\
\hline Coniferous forests & 5 \\
Pinyon-juniper & 3 \\
Mixed shrub & 1 \\
All others & 0 \\
\hline
\end{tabular}

Slope-aspect determines the amount of direct solar radiation received on a hillslope and the amount of drying activity that occurs during the day. Therefore, a slope-aspect based recharge potential map was developed by assigning north and east facing slopes higher recharge potential ratings and south and west facing slopes lesser recharge potential ratings (table 8).

Table 8. Potential recharge classification for slope-aspect zones

\begin{tabular}{lc}
\hline \multicolumn{1}{c}{ Slope-aspect zone } & Recharge ratling \\
\hline Northeast & 5 \\
Northwest & 4 \\
Flat & 3 \\
Southeast & 2 \\
Southwest & 1 \\
\hline
\end{tabular}

The bedrock material through which water will infiltrate during a recharge event affects recharge potential. Therefore, the relative permeability of bedrock materials and the soils developing on them can be used to develop a permeability-based, recharge potential map. For example, parent materials that develop high permeability soils, such as alluvium, carbonate, granite, sandstone, and gneiss, may be assigned higher ratings, while rocks that develop low permeability soils, such as tuff, siltstone, argillite, and shale, may be assigned lesser ratings. Locally, low permeability soils may lead to runoff and recharge in an adjacent area. These effects, however, were not factored into this regional assessment. Such considerations allowed development of the ratings shown in table 9 based on the hydrogeologic map.

Table 9. Potential recharge classification for parent material types

\begin{tabular}{lc}
\hline $\begin{array}{c}\text { Hydrogeologic unit } \\
\text { (fig. 8) }\end{array}$ & Recharge rating \\
\hline QTvf & 5 \\
TJg, Mvs, pGgm & 4 \\
P2 & 3 \\
Qp, QTv, Tv, P1 & 2 \\
Tvs & 1 \\
\hline
\end{tabular}

The four recharge potential maps were overlaid to produce a map that combined the ratings from each map (fig. 25). The most significant factor in this classification is altitude. This factor is explicitly included in the altitude-based recharge potential map, but it is also implicitly included in the vegetationbased recharge potential map. Vegetation distributions are dominantly controlled by altitude and moisture availability.

The final recharge potential map (fig. 25) contained high values where many favorable recharge factors were coincident. If one of the four recharge potential maps contained a rating of zero, the final map was assigned no recharge potential (zero). The values were reclassified into six zones representing areas having similar recharge potentials (fig. 25).

The areas most likely to have high recharge potential were those that possessed all four favorable factors. For example, high recharge potential would most likely occur on northeast facing slopes, at altitudes higher than $2,743 \mathrm{~m}$, where coniferous trees are growing on alluvial soils. Low recharge potential 


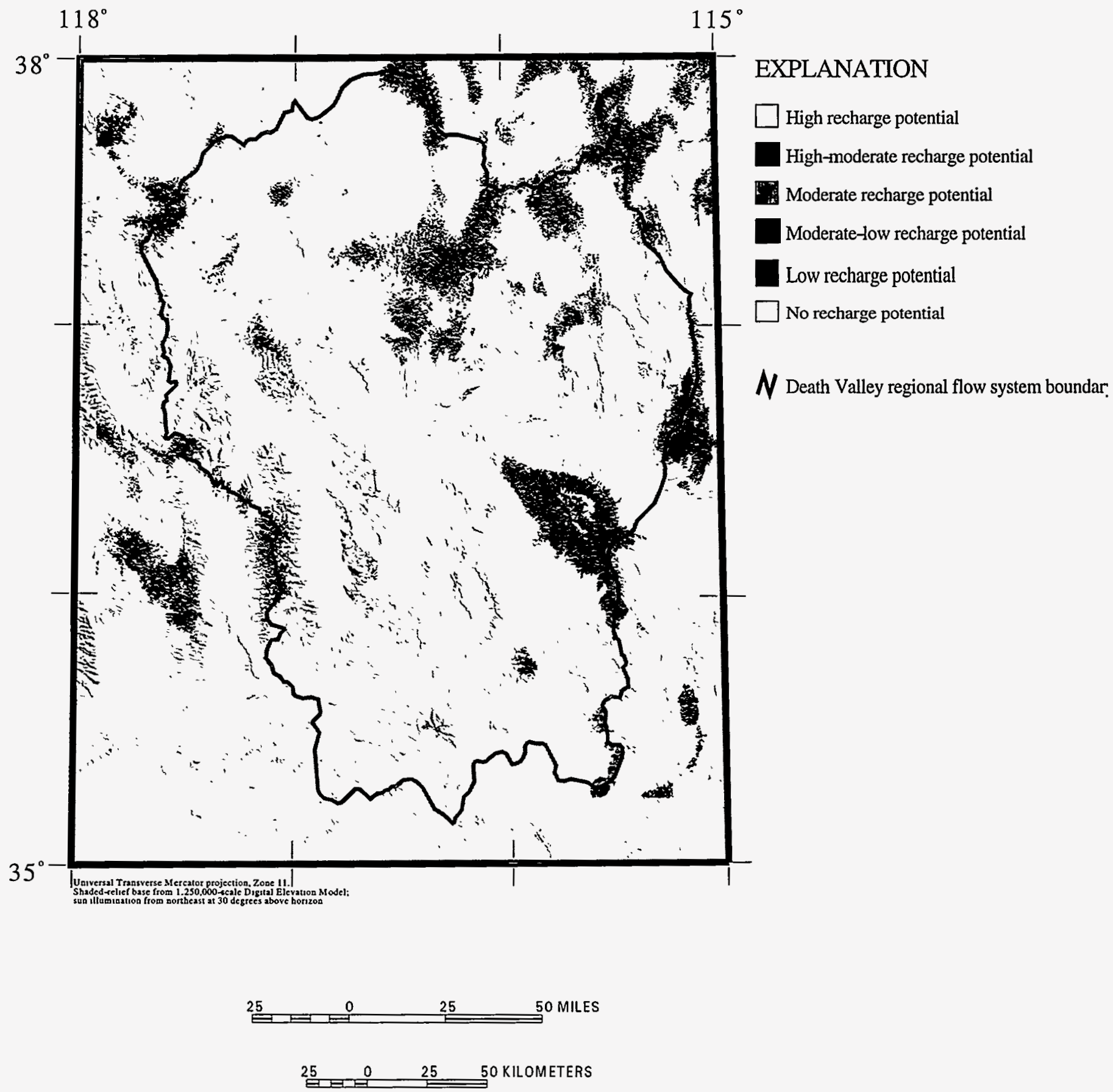

Figure 25. Refined potential recharge areas for the Death Valley region. 
would exist on southwest facing slopes, at altitudes lower between 1,524 and $1,829 \mathrm{~m}$, where mixed shrub communities are growing on clayey soils derived from argillaceous volcanic rocks.

\section{Refined Recharge Estimation}

As with the Maxey-Eakin method, these refined recharge potential classes were assigned distinctive percentages of mean annual precipitation that are expected to contribute to recharge (table 10). Because Miller (1977) suggested that more than 25 percent of average annual precipitation may be recharged in wet, high-altitude areas, 30 percent was assigned to the high recharge potential class. For the lower recharge potential classes, the Maxey-Eakin percentages were used. This resulted in a higher rate of recharge for areas more conducive to infiltration. A refined recharge map was developed by multiplying these recharge-percentages for each class by the average annual precipitation values (J.A. Hevesi, U.S. Geological Survey, written commun., 1995).

Table 10. Final recharge potential zones and relative recharge percentages

\begin{tabular}{clc}
\hline $\begin{array}{c}\text { Class } \\
\text { number }\end{array}$ & Recharge potential & $\begin{array}{c}\text { Estimated average } \\
\text { rate } \\
\text { (percentage of } \\
\text { precipitation) }\end{array}$ \\
\hline 5 & High & 30 \\
4 & High-moderate & 25 \\
3 & Moderate & 15 \\
2 & Moderate-low & 7 \\
1 & Low & 3 \\
0 & No recharge & 0 \\
\hline
\end{tabular}

\section{Accuracy and Suitability of Refined Method}

To evaluate the accuracy and appropriateness of the refined predicted recharge areas for regional ground-water flow modeling purposes, a map of these refined recharge areas was compared to maps showing locations of low-temperature springs and vegetation types. Upon careful inspection, areas uphill from lowtemperature springs, regardless of altitude, were found to be coincident with predicted regional recharge areas. Because vegetation constraints were incorporated in the rating criteria, all predicted recharge areas were restricted to vegetation zones classified as either Coniferous Forests, Pinyon-Juniper Woodlands, or
Mixed Transition Shrublands. As a result, the refined recharge areas map was considered an improvement to the map based on the traditional Maxey-Eakin method and an acceptable indicator of areas in the region where long-term, regional ground-water recharge may occur (D'Agnese and others, 1996). While these may not exactly describe recharge locations on a local scale, they appear to be appropriate for delineating large-scale zones of recharge that is consistent with previous investigations (Prudic and others, 1993, p. 23-24). Even with better defined potential recharge areas, recharge rates are still based on empirical estimates rather than actual measured rates and reflect a significant unknown flux in modeling this region.

\section{Evaluation of Current Recharge Estimate}

To evaluate the suitability of recharge rates for conceptualization and numerical simulation, the total volume of recharge in each of the hydrographic basins was calculated. These recharge volumes were compared to previous Maxey-Eakin estimates (table 11).

In general, the values of recharge computed by the refined Maxey-Eakin method used in this study are slightly higher than those computed by previous investigations and the total amount of estimated recharge is 30 percent greater than Maxey-Eakin recharge estimates for the Death Valley flow system. These differences may be attributed to the following:

1. The recharge rates are computed using percentages of the estimated average annual precipitation developed by Hevesi and others (U.S. Geological Survey, written commun., 1995). Their rates may reflect slightly higher region-wide precipitation rates.

2. Hydrographic areas in the northern and eastern parts of the region are estimated to have larger rates of recharge than by the Maxey-Eakin method. These basins are located at higher altitudes than the remainder of the study area. They typically possess highly permeable soils (alluvium and carbonate derived), and support vegetation that require high precipitation rates to survive. These conditions are believed to result in high recharge potential in these basins.

3. Hydrographic areas in the central and southern parts of the region are generally estimated to have smaller rates of recharge than by the Maxey-Eakin method. The lower estimates are 
Table 11. Comparisons of recharge estimates for this study with Maxey-Eakin estimates

$\left[\mathrm{m}^{3} / \mathrm{d}\right.$, cubic meters per day $]$

\begin{tabular}{|c|c|c|c|}
\hline \multirow[b]{2}{*}{$\begin{array}{l}\text { Hydrographic } \\
\text { area number }\end{array}$} & \multirow[b]{2}{*}{ Hydrographic area } & \multicolumn{2}{|c|}{ Recharge estlmate } \\
\hline & & $\begin{array}{c}\text { Maxey-Eakin } \\
\left(\mathrm{m}^{3} / \mathrm{d}\right)\end{array}$ & $\begin{array}{l}\text { Present study } \\
\left(\mathrm{m}^{3} / \mathrm{d}\right)\end{array}$ \\
\hline 144 & Lida Valley & 1,600 & 6,600 \\
\hline 145 & Stonewall Flat & 300 & 2,800 \\
\hline 146 & Sarcobatus Flat & 4,100 & 5,000 \\
\hline 147 & Gold Flat & 12,800 & 22,400 \\
\hline 148 & Cactus Flat & 2,000 & 10,400 \\
\hline 157 & Kawich Valley & 11,800 & 25,500 \\
\hline 158 & Emigrant Valley & 10,800 & 43,900 \\
\hline 159 & Yucca Flat & 2,400 & 6,300 \\
\hline 160 & Frenchman Flat & 300 & 3,300 \\
\hline 161 & Indian Springs Valley & 33,800 & 27,600 \\
\hline 162 & Pahrump Valley & 74,300 & 68,400 \\
\hline 163 & Mesquite Valley & 9,800 & 7,300 \\
\hline 168 & N. Three Lakes Valley & 6,800 & 4,000 \\
\hline 169 & Tikaboo Valley & 20,300 & 33,200 \\
\hline 211 & S. Three Lakes Valley & 20,300 & 24,800 \\
\hline $225 / 226$ & Mercury/Rock Valleys & 1,000 & 1,300 \\
\hline 227 & Fortymile Canyon & 7,800 & 2,300 \\
\hline 228 & Oasis Valley & 3,400 & 10,300 \\
\hline 229 & Crater Flat & 700 & 400 \\
\hline 230 & Amargosa Valley & 5,100 & 1,400 \\
\hline 241 & California/Chicago Valleys & 1,000 & 1,600 \\
\hline 242 & Lower Amargosa Valley & 300 & 100 \\
\hline 243 & Death Valley & 32,400 & 32,400 \\
\hline
\end{tabular}

attributed to the low recharge potential characteristics of these basins. These lower estimates suggest that the Maxey-Eakin elevationprecipitation-recharge relations, which were developed in the northern Great Basin, may not be good recharge estimation techniques in the Transition Desert and Mojave Desert.

4. Some previous investigators (Malmberg and Eakin, 1962; Walker and Eakin, 1963; Malmberg, 1967) adjusted the Maxey-Eakin recharge percentages in basins to refiect the large discharge volumes observed. Many of these large discharge volumes probably reflect inter-basinal fluxes and not infiltration of locally recharged waters.

\section{Characterizing the Regional Potentio- metric Surface}

\section{Previous Potentiometric-Surface Maps}

A large number of potentiometric-surface maps have been developed for basins within the Death Valley region. Most have been generalized maps of shallow unconfined basin-fill aquifers (Malmberg and Eakin, 1962; Walker and Eakin, 1963; Malmberg, 1967; Kilroy, 1991). Only a few investigations have included more detailed maps of shallow and deep regional flow in consolidated rock (Rush, 1970; Thordarson and Robinson, 1971; Blankennagel and Weir, 1973; Winograd and Thordarson, 1975; Robison, 1984; Waddell and others, 1984). 
Thomas and others (1986) developed a map of ground water levels for the Great Basin. Bedinger and others (1984 a,b) and Langer and others (1984) developed maps of ground-water levels and spring discharges for the Nevada and California parts of the Death Valley region, respectively. During these investigations, they noted the difficulty in extrapolating water levels over large distances. Significant conclusions drawn from these investigations include the following:

1. Although regional water-level data are spread temporally over several decades, most data for any given basin were gathered during short periods of time;

2. In the basin-fill deposits, the saturated zone is relatively continuous, although perched ground water may occur in isolated areas; and

3. In consolidated bedrock areas with significant topographic relief, particularly in highly fractured areas where numerous aquifers are hydraulically connected, the depth to ground water can be predicted with reasonable accuracy between widely spaced water-level data points, except where regional geologic discontinuities, such as fault zones, affect regional flow.

A relatively detailed representation of the regional potentiometric surface in the vicinity of Yucca Mountain was developed by Waddell and others (1984). Their map incorporated water levels from several hydrogeologic units. In some areas, such as Yucca Flat, data were available from wells completed in alluvium, tuff and carbonate rocks (Winograd and Thordarson, 1975). The potentiometric altitudes from these distinct units indicated a downward flow toward the carbonate aquifer, but Waddell and others (1984) concluded that potentiometric levels are so similar on a regional scale that contouring separate potentiometric surfaces was not feasible.

\section{Construction of an Estimated Regional Potentiometric-Surface Map}

A new regional potentiometric-surface map was constructed for this study using data sets describing regional water levels, boundaries of perennial marshes and ponds, topographic altitudes, regional spring locations, the distribution of recharge and discharge areas, and hydrogeology. Supplementary data were used to help in the extrapolation of water levels in data poor areas.

\section{Water-Level Data}

Water level data for 2,141 wells were retrieved from the USGS NWIS data base. Because little information was available in the data base on the screened intervals of these wells, the majority of the levels were considered to represent the water table, or to be composite water-level measurements of the regional potentiometric surface.

\section{Limitations of Water-Level Data}

In this sparsely populated, arid, and mountainous region, water-resource extraction and investigation has been mostly concentrated in alluvial basins. As a result, water-level data are concentrated in these basins. The densest concentration of waterlevel data occurs near Las Vegas, Nevada, east of the Death Valley regional ground-water flow system. Dense concentrations of water-level data occur in the two largest agricultural communities, Amargosa and Pahrump Valleys (fig. 26). Additional water-level data are located within the basin fill in Oasis Valley, Sarcobatus Flat, and Yucca Flat (fig. 26). The only areas with extensive water-level data in consolidated bedrock are Yucca Mountain and the atomic testing areas of Pahute and Rainier Mesas. The remainder of the region lacks extensive water-level information (fig. 26).

\section{Incorporation of Comparative Data}

An automated gridding and contouring software package was used to initially interpolate the data. Numerous intermediate gridding steps were conducted, and adjustments made using handcontouring methods. Because of the limited data from water wells, additional ancillary data were used to assist the potentiometric surface map construction. These data were used to guide interpolation of water levels in data-poor areas, in accordance with five general criteria:

1. During interpolation, water levels were not permitted to extend above the land surface, as defined by the DEM.

2. The altitudes of regional springs, perennial marshes and ponds were used to define locations where the regional water table occurs at the land surface.

3. Regional discharge areas are regional sinks in the flow system and are located at local minima in 


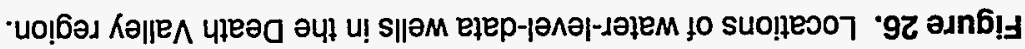

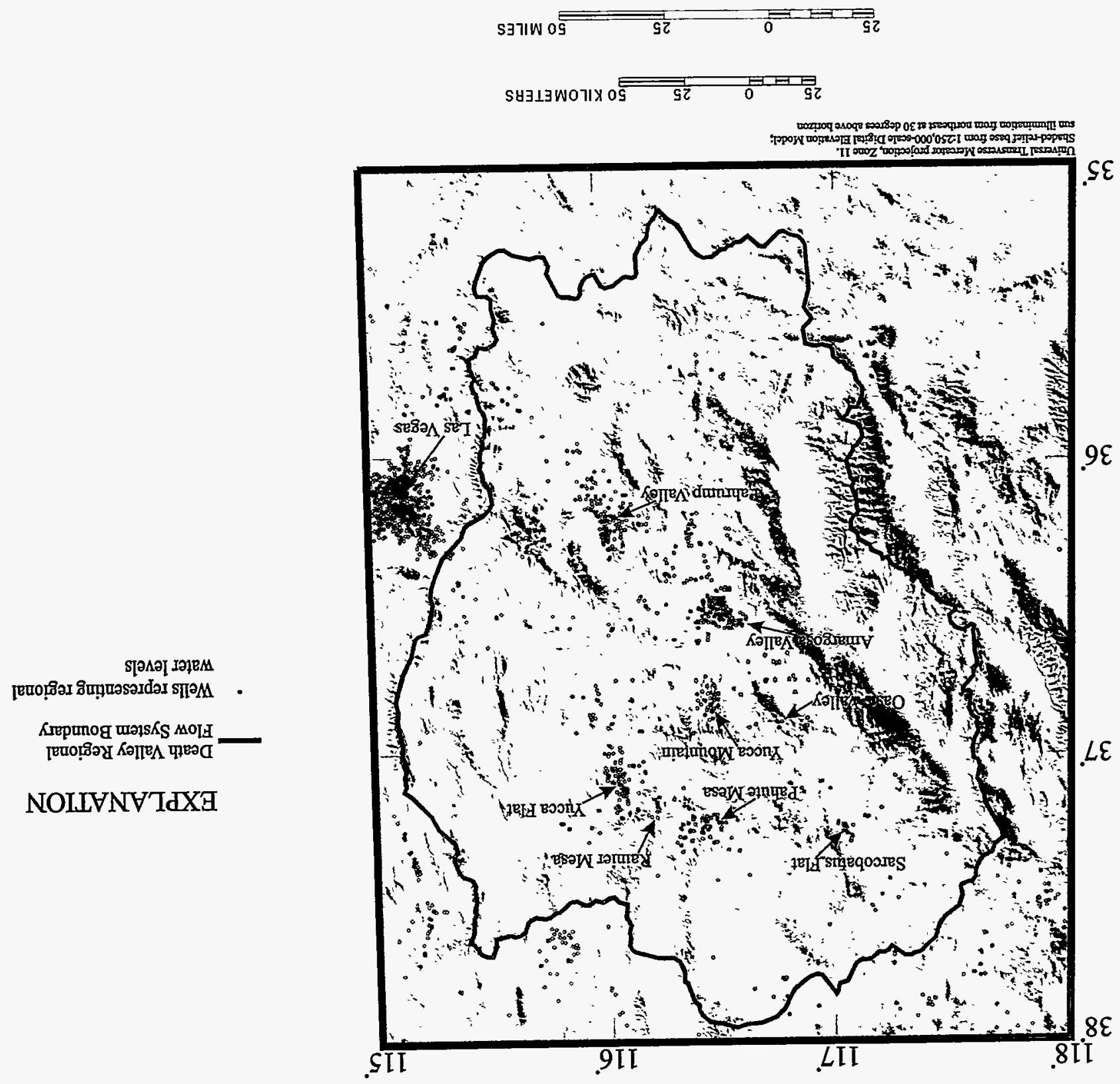


the regional potentiometric surface. Therefore, the potentiometric surface at discharge areas was interpolated to form local minima.

4. Regional recharge areas develop recharge mounds (and often, ground-water divides) in the potentiometric surface. Therefore, the potentiometric surface was interpolated to form local maxima at locations of recharge areas.

5. The potentiometric surface typically reflects the presence of lower permeability rocks. The potentiometric surface contours sharply refract into the units with lower permeability, resulting in areas with steep hydraulic gradients. The hydrogeologic map was used to delineate locations of lower permeability rock at the surface or subsurface. During interactive interpolation of the potentiometric surface, gradients on the interpreted potentiometric surface were steepened as necessary to reflect these hydrogeologic barriers.

Where conformity to regional conditions and conceptualizations of the regional ground-water flow system appeared necessary or desirable, the potentiometricsurface map (fig. 27) reflects these manual interpretations.

\section{CONCEPTUALIZATION OF REGIONAL GROUND-WATER FLOW}

A conceptual model of the Death Valley regional ground-water flow system was developed by integrating interpretations of flow system components. Discussion of the flow system dynamics includes a description of regional, subregional and sub-basin boundaries, as well as the source, occurrence, and movement of ground water in the system.

\section{Flow System Boundaries}

The Death Valley regional flow system consists of ground water moving through 3D body of consolidated and unconsolidated materials. Faunt (1994) and D'Agnese (1994) described the characteristics of this saturated volume, and the current report summarizes these characteristics. The flow system boundaries may be either physical boundaries, caused by changes in bedrock conditions, or hydraulic boundaries, caused by potentiometric surface configurations. The upper boundary of the flow system is the water table. The lower boundary of the flow system is located at a depth where ground-water flow is dominantly horizontal and moves with such small velocities that the volumes of water involved do not significantly impact regional flow estimates. The lateral limits of the regional flow system may be either no-flow or flow boundaries. No-flow conditions exist where ground water movement across the boundary is prevented by physical barriers or divergence of ground-water flow paths. Flow boundaries exist where ground-water potentiometric gradients permit flow across a boundary through fractures or higher permeability zones.

\section{Regional Boundaries}

The lateral boundaries selected for the flow system (fig. 28) are modified from those described by Waddell and others (1984), Harrill and others (1988), and Bedinger and others (1989c). Most system boundaries are no-flow boundaries that result from the presence of low-permeability bedrock. Flow boundaries occur where bedrock has a high enough permeability to allow significant ground-water fluxes to enter the system and where a hydraulic gradient exists across the boundary. Faulting and fracturing most frequently cause the enhanced permeability, and ground-water flow may occur at various depths through open regional fracture zones. Based on potentiometric and hydrogeologic framework data, areas where inflow may occur from are Pahranagat Valley (fig. 28, \#1), Sand Spring Valley (\#2), Railroad Valley (\#3), Stone Cabin Valley (\#4), Ralston Valley (\#5), Fish Lake and Eureka Valleys (\#6), Saline Valley (\#7), Panamint Valley (\#8), Pilot Knob Valley (\#9), and Soda Lake Valley (\#10). Good estimates of flow across these lateral flux boundaries do not exist except for Pahranagat Valley, which has been estimated by Winograd and Friedman (1972) to be approximately $20,000 \mathrm{~m}^{3} / \mathrm{d}$. The remaining areas have very little data required to estimate flux volumes; however, flux across these boundaries should not be dismissed without further investigation (J. Harrill, Pal Consultants, written commun., 1995).

The flow system boundary in northern Las Vegas Valley near Corn Creek Springs (fig. 28, \#11) results from the presence of a ground-water divide. Ground water recharging from the Sheep and Spring Mountains forms a ground-water divide that extends across the valley and separates flow that moves south- 


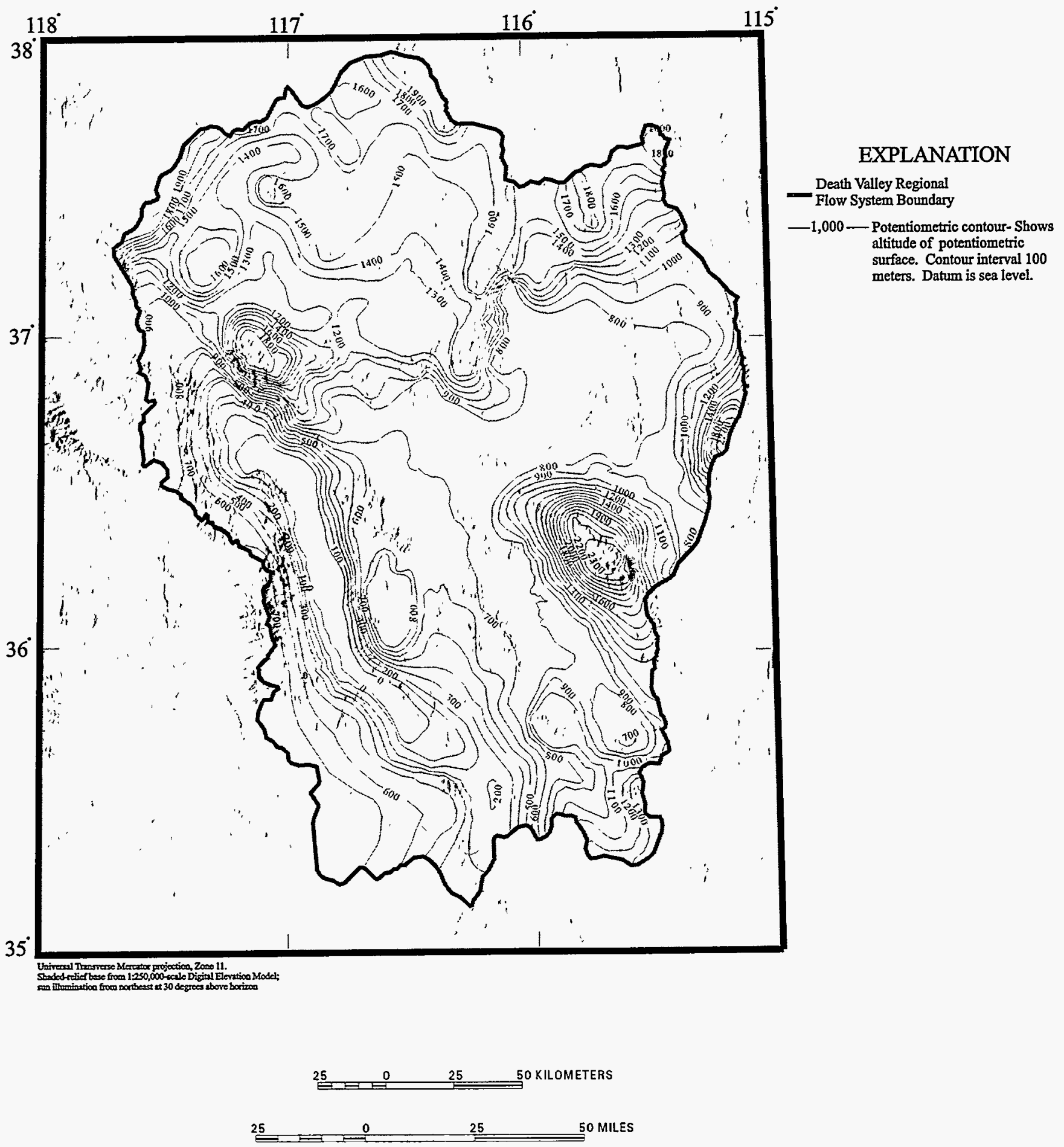

Figure 27. Estimated potentiometric surface of the Death Valley region. 


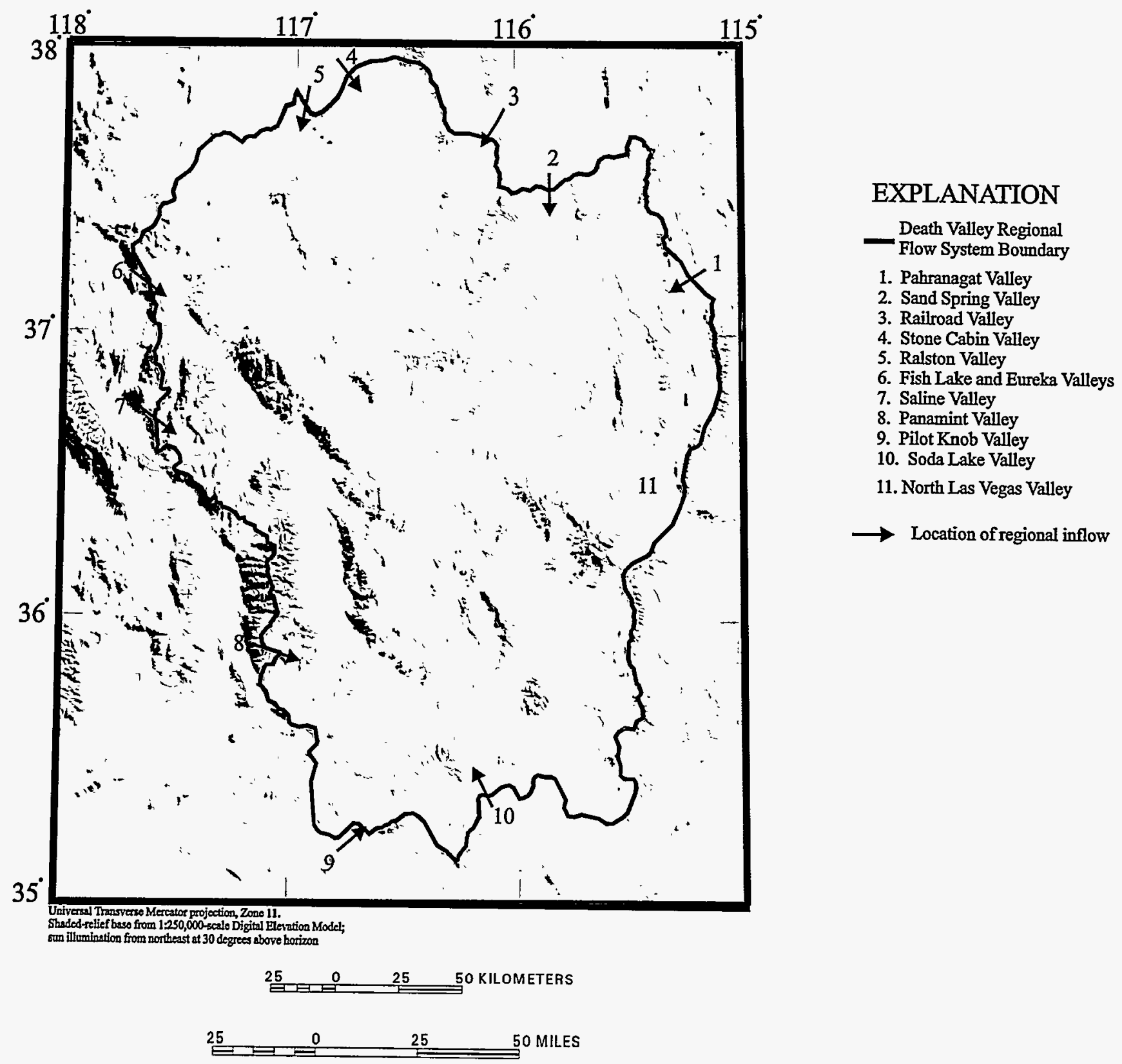

Figure 28. Locations of regional inflows across flow system boundaries. 
east toward Las Vegas Valley from fiow that moves to the north-west toward Ash Meadows in the Amargosa Valley.

For numerical simulation, the flow system was subdivided into 3 subregions that represent the areas where regional ground-water flow moves from recharge areas in Nevada toward the Death Valley saltpan, the ultimate terminus of the system (fig. 29). Local recharge along the southern boundary of the system and subsurface inflows along parts of the southeastern and southern boundary of the system were not included in the simulation. These model boundaries are based on previously defined flow system boundaries (fig. 28), the potentiometric surface developed for this study (fig. 27), and the hydrogeologic framework. Few data exist that would allow a precise definition of the western and southern extent of the flow system. The western boundary of the flow system is placed to coincide with the eastern edge of the Death Valley saltpan, which is interpreted as the terminal sink of the flow system. Although some ground water that originates on the west side of Death Valley may discharge into the saltpan, this discharge is mostly at Mesquite Flat and is a small volume compared to the contribution from the east (Prudic and others, 1993).

\section{Subregional Boundaries}

For this study, the Death Valley regional ground-water flow system was divided into three major subregional flow systems (fig. 29). The names of the subregions reflect the part of Death Valley into which each discharges. For example, the Northern Death Valley subregion discharges into the northern part of Death Valley at Grapevine and Staininger Springs and Mesquite Flat. The Central Death Valley subregion predominantly discharges into the main Death Valley saltpan at Cottonball, Middle, and Badwater Basins, and the Southern Death Valley subregion discharges into the Saratoga Springs area at the southern terminus of Death Valley.

Ground-water flows across the subregional boundaries in three places (fig. 29). Ground water flows across the southeast border of the Central Death Valley subregion from the Amargosa Desert into the Lower Amargosa Valley in the Southern Death Valley subregion. Ground water flows from the Northern Death Valley subregion across a boundary at Salt Creek Springs (just south of Mesquite Flat) into the Central Death Valley subregion. At the southern end of Death Valley, ground water that has not discharged in the Saratoga Springs area may continue to flow northward from the Southern Death Valley subregion across the subregion boundary to discharge at Badwater Basin in the Central Death Valley subregion.

\section{Source, Occurrence, and Movement of Ground Water}

Description of the source, occurrence, and movement of ground water in the Death Valley regional ground-water flow system is most easily undertaken according to the subregions. Flow in each subregion has clearly defined flow paths. For convenience, the subregions are subdivided into basins and sections (table 12 and fig. 30). These boundaries are used for descriptive purposes only, and these subregions, ground-water basins, and sections do not define discrete independent flow systems.

Table 12. Divisions of the Death Valley regional groundwater flow system

NORTHERN DEATH VALLEY SUBREGION
a. Lida-Stonewall Section
b. Sarcobatus Flats Section
c. Grapevine Canyon Section
d. Oriental Wash Section

CENTRAL DEATH VALLEY SUBREGION

(1) Pahute Mesa - Oasis Valley Ground-Water Basin

a. Kawich Valley Section

b. Oasis Valley Section

(2) Ash Meadows Ground-Water Basin
a. Pahranagat Valley Section
b. Tikaboo Valley Section
c. Indian Springs Valley Section
d. Emigrant Valley Section
e. Yucca-Frenchman Flat Section
f. Specter Range Section

(3) Alkali Flat-Furnace Creek Ground-Water Basin
a. Fortymile Canyon Section
b. Amargosa River Section
c. Crater Flat Section
d. Funeral Mountains Section

SOUTHERN DEATH VALLEY SUBREGION
a. Pahrump Valley Section
b. Shoshone-Tecopa Section
c. California Valley Section
d. Ibex Hills Section 


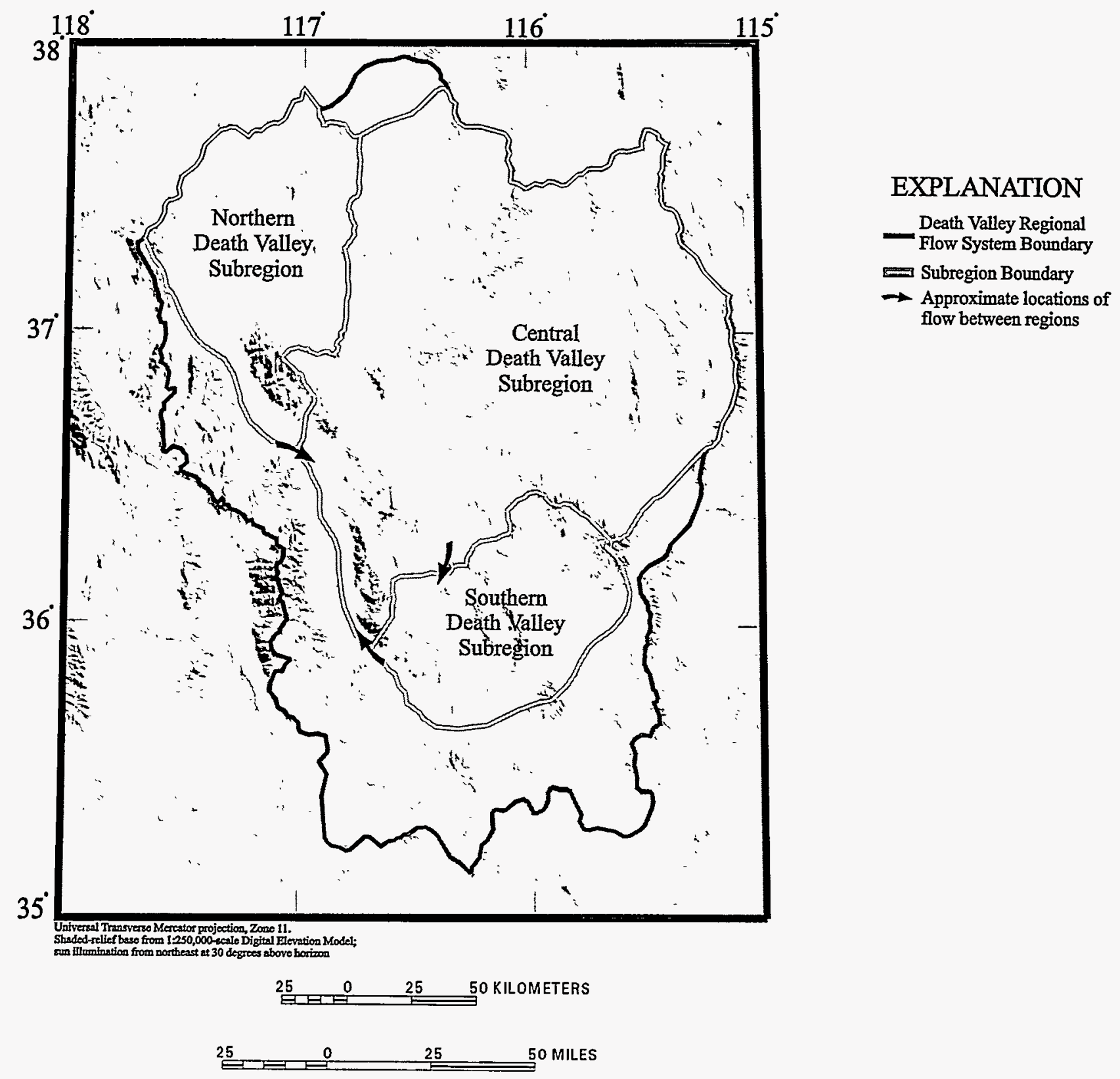

Figure 29. The three subregions of the Death Valley regional ground-water flow system that encompass the area modeled in this study. 


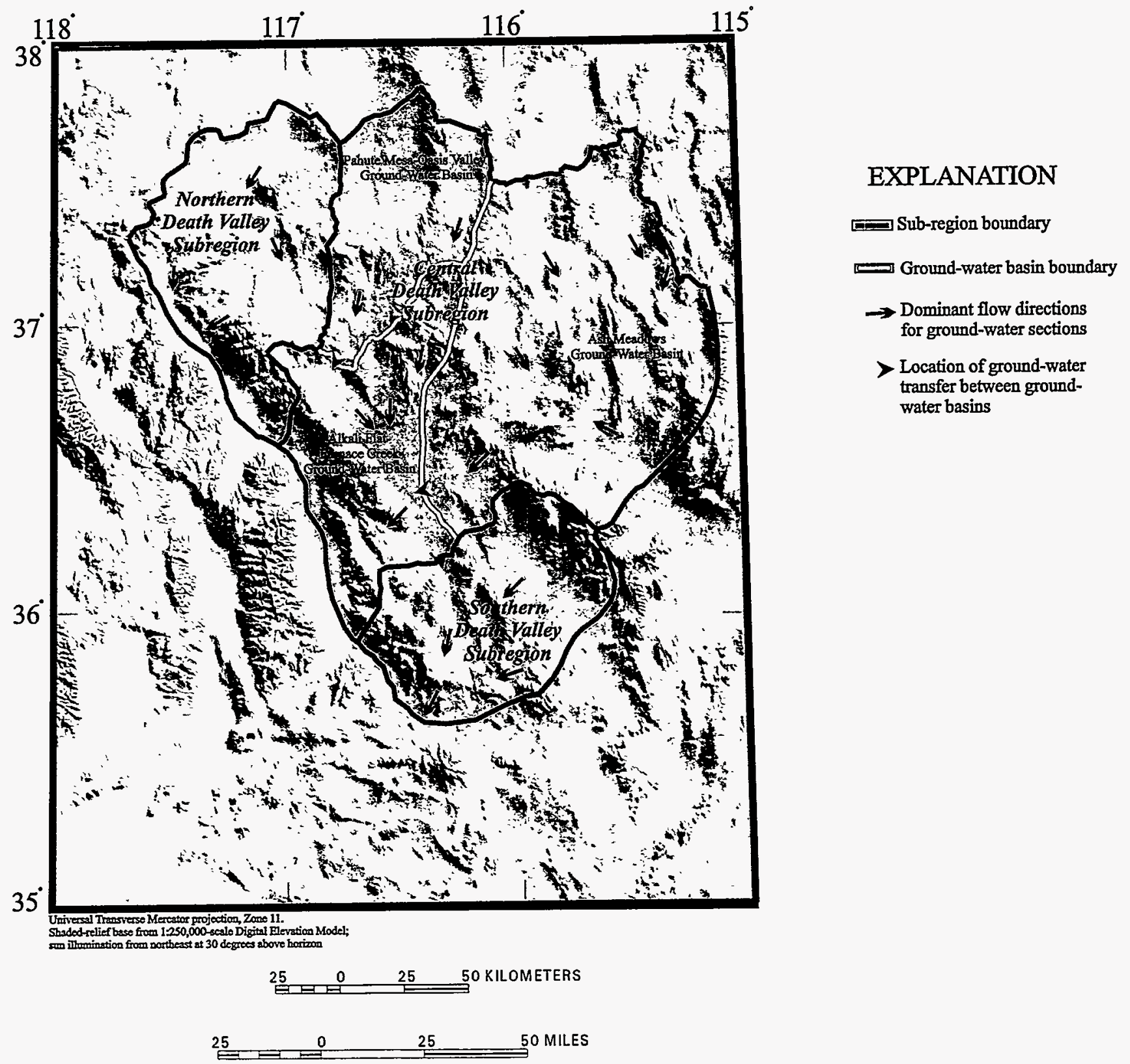

Figure 30. Subregions, ground-water basins, and associated flow paths of the Death Valley regional ground-water flow system. 


\section{Northern Death Valley Subregion}

Ground water in the Northern Death Valley subregion is derived from precipitation on high altitudes of the Montezuma Range and the Palmetto, Gold and Stonewall Mountains. An unknown volume of ground water may also be entering the subregion across the system boundary from Ralston Valley (fig. 28, \#5).

Ground water recharged on the mountains in the northwest part of this subregion moves toward the central axes of adjacent valleys. In this subregion, the potentiometric surface indicates that much of the ground-water flow appears to be controlled by the NE/SW trending structural zones described by Carr (1984). Deep regional interbasinal flow is unlikely because the subregion is mostly underlain by relatively impermeable shallow Tertiary intrusive granites and crystalline Precambrian rocks. The regional carbonate aquifer is believed to be extensive and continuous only in the southeastern part of the subregion (Grose, 1983), near western Pahute Mesa and southern Sarcobatus Flats. Four dominant ground-water sections associated with four discharge areas (fig. 31), contain the majority of flow in the basin: the Lida-Stonewall section, the Sarcobatus Flats section, the Grapevine Canyon section, and the Oriental Wash section.

The Lida-Stonewall section (fig. 31) contains discharge areas at East and West Stonewall Flat, and the playa near Lida Junction. Ground water evapotranspired in the areas is believed to be derived mostly from within the Northern Death Valley subregion, however, some water may travel at great depths along buried NE/SW trending linear features near Ralston Valley to these discharge areas.

The Sarcobatus Flats section (fig. 31) contains discharge areas at Sarcobatus Flats and Coyote Holes playas. These areas are believed to evapotranspire ground water that has moved along subregional flow paths. At Coyote Holes playas, restriction of groundwater flow by bedrock at shallow depths immediately south of the playas results in ET of ground water that may originate on western Pahute Mesa. As with the Lida-Stonewall section, a NE/SW trending linear feature may affect regional ground-water flow patterns. For example, ground water originating from Cactus and Gold Flats in the northeast may be forced to the surface and discharged at Bonnie Claire and Sarcobatus Flats.
The Grapevine Canyon section contains a major discharge area at Grapevine and Staininger Springs. Discharge at these sites appears to originate as ground water that has flowed from the northeast to the southwest past Stonewall and Sarcobatus Flats. The springs also may result from structural and topographic controls. The intersection of the lowpermeability, NW/SE trending Death Valley fault with an apparently large-permeability NE/SW trending structural zone (Carr, 1984; Faunt, in press) may result in the truncation of the large-permeability zone causing ground water to discharge.

The Oriental Wash section includes a small discharge area at Sand Springs in northern Death Valley. These comparatively low-temperature and small-volume springs appear to be discharging locally-derived ground water recharged on the dominantly granitic mountains to the north. Ground water flow is apparently directed toward the springs along the axis of Oriental Wash, which is associated with a NE/SW trending structural zone (Carr, 1984; Faunt, in press), and the discharges occur along the northern terminus of the Death Valley fault.

\section{Central Death Valley Subregion}

In the Central Death Valley subregion, the dominant flow paths have historically been associated with major regional or subregional discharge areas. In this subregion, flow paths have traditionally been grouped into three ground-water basins, each containing several sections (fig. 32): Pahute MesaOasis Valley ground-water basin, Ash Meadows ground-water basin, and Alkali Flat-Furnace Creek ground-water basin.

\section{Pahute Mesa-Oasis Valley Ground-Water Basin}

Ground water in the Pahute Mesa-Oasis Valley basin is derived from infiltration in the Kawich and Belted Ranges and Pahute Mesa. Additional recharge may occur as regional ground-water flows across system boundaries from Railroad Valley and Stone Cabin Valley (fig. 28, \#3 and \#4). Because the western boundary of this basin is poorly defined, ground water in the western part of the basin (parts of Cactus and Gold Flats), may flow toward the eastern part of Sarcobatus Flats. This ground-water basin has two dominant sections: the Kawich Valley section and the Oasis Valley section (fig. 32). 

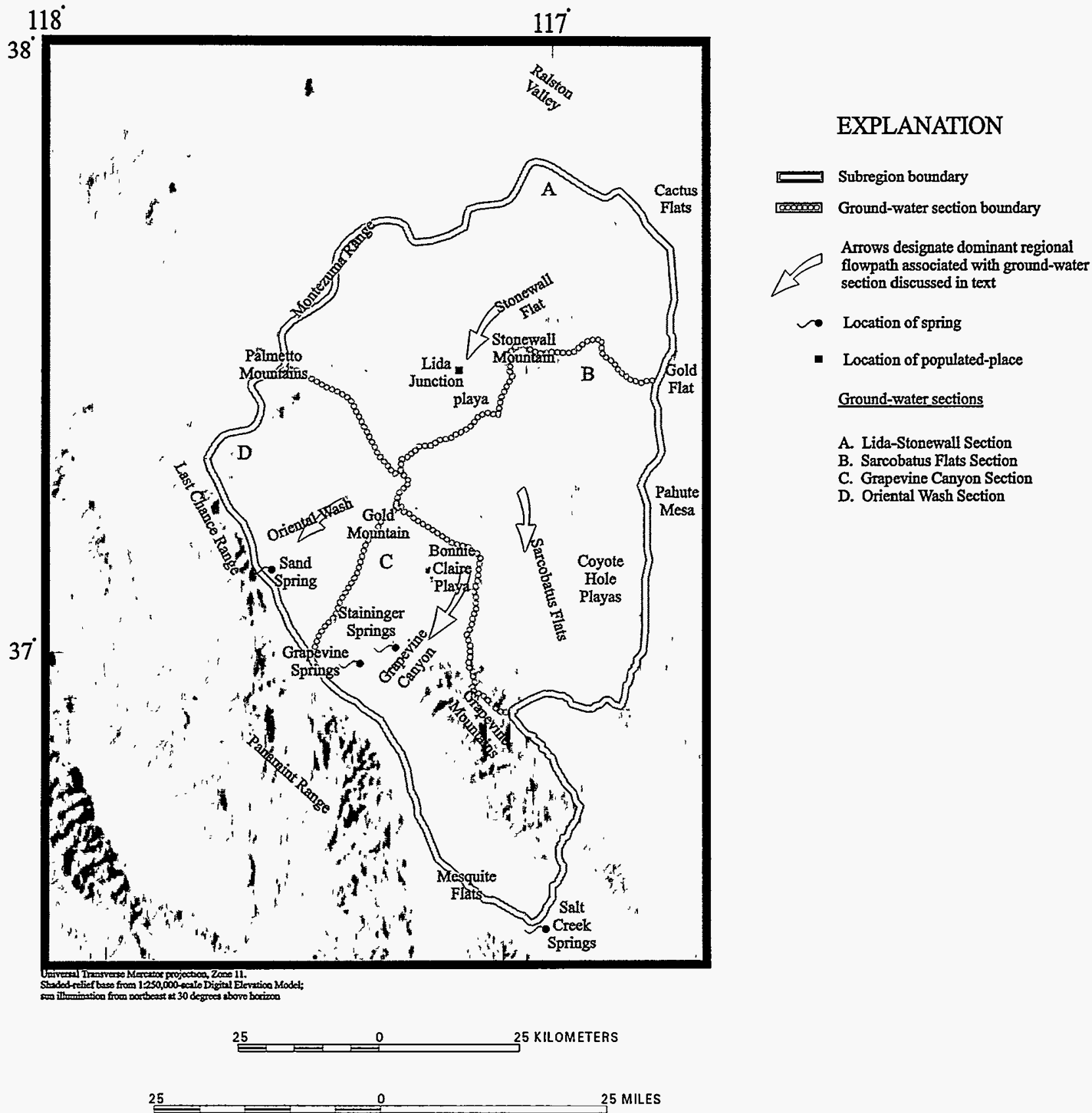

Figure 31. The Northern Death Valley subregion. 


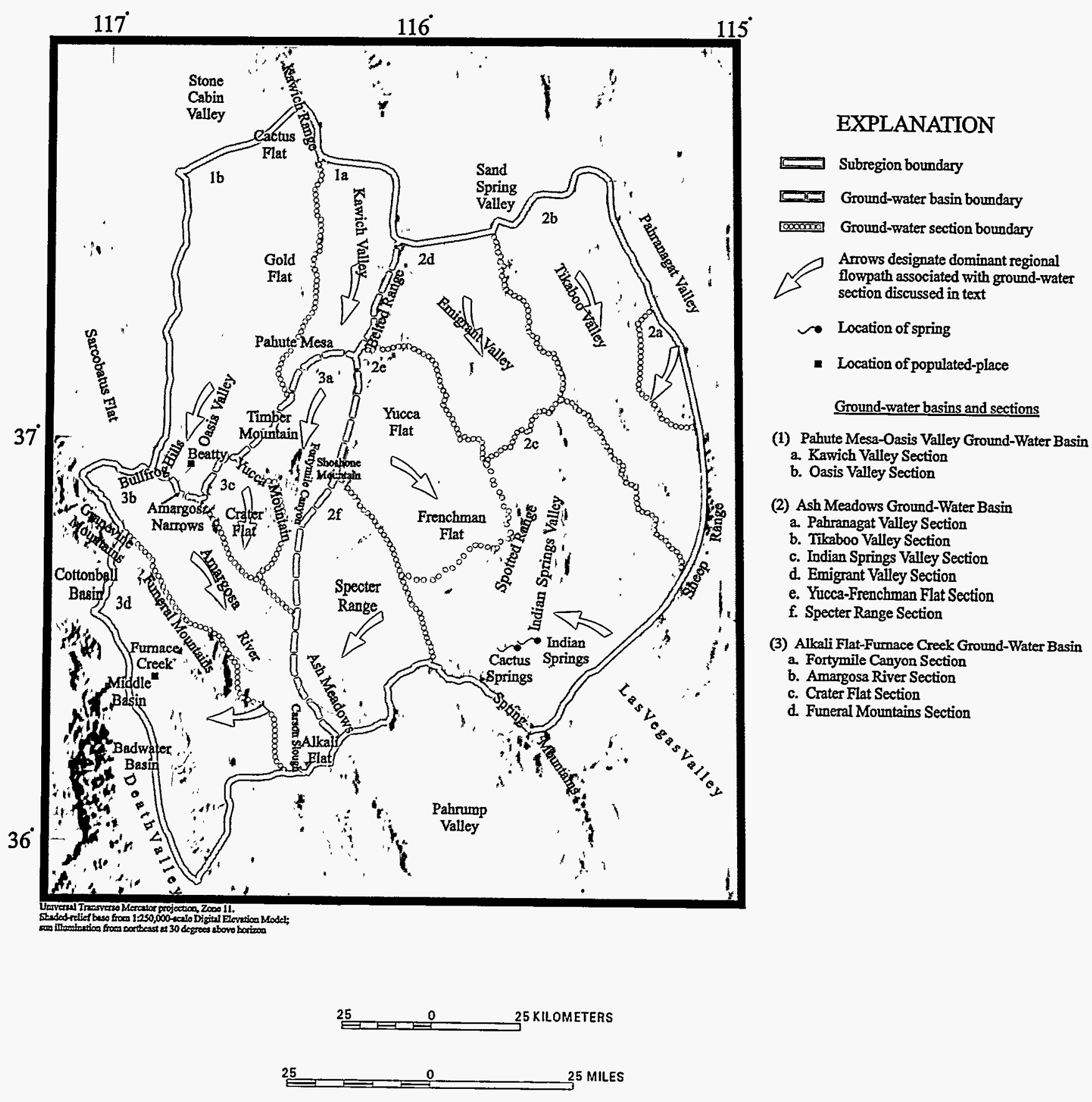

Figure 32. The Central Death Valley subregion. 
In general, ground water recharged on the nearby mountains moves toward the central axes of Kawich and Oasis valleys. Ground water in the Kawich Valley section may flow toward a potentiometric-surface trough located under western Pahute Mesa (Waddell and others, 1984). A possible regional fault or fracture zone has been described at this location (Blankennagel and Weir, 1973). Water flowing along this trough toward Oasis Valley comprises the Oasis Valley section of this basin. At Oasis Valley ground water is discharged by ET and spring flow. Ground water that does not discharge within Oasis Valley flows through the subsurface at the Amargosa Narrows south of Beatty and into the Alkali Flat-Furnace Creek ground-water basin (Waddell, 1982). Small amounts of ground water in Oasis Valley also may flow toward Crater Flat under Bear Mountain.

\section{Ash Meadows Ground-Water Basin}

The Ash Meadows ground-water basin is the largest basin in the Central Death Valley subregion. Much of the ground water in this basin is derived from infiltration on the mountain ranges that surround the basin. Additional recharge may occur as regional ground water flows across system boundaries from Sand Spring Valley (Waddell, 1982) and Pahranagat Valley (Winograd and Thordarson, 1974) (fig. 28, \#1 and \#2). This basin is subdivided into six sections (fig. 32): Pahranagat Valley section, Tikaboo Valley section, Indian Springs Valley section, Emigrant Valley section, Yucca-Frenchman Flat section, and Specter Range section.

Ground water recharged on mountains moves toward the anomalously large potentiometric-surface trough within the basin. Ground water in Tikaboo Valley, Emigrant Valley, and Yucca and Frenchman Flats is interpreted as flowing toward this trough. Regional and subregional ground water recharged on the Sheep and Spring Mountains also flows into this trough from the south and east, thereby contributing to ground-water flow past Indian Springs Valley (fig. 32).

The potentiometric-surface trough may be a zone of high permeability associated with the Spotted Range-Mine Mountain structural zone (Carr, 1984) (fig. 7) and is believed to include numerous regional faults and fractures (Winograd and Thordarson, 1975; Faunt, in press). The trough is bounded on the south and southeast by the Las Vegas Valley shear zone (fig. 6). The shear zone may contain low-permeability material, possibly fault gouge (Winograd and Thordarson, 1975), causing discharge at Indian and Cactus Springs. The flow paths along the trough are directed through the Specter Range area until they encounter a NW/SE trending fault at Ash Meadows. This fault causes much of the ground water to be discharged as spring flows and ET (Winograd and Thordarson, 1975). Ground water that does not discharge at Ash Meadows flows into the Alkali FlatFurnace Creek ground-water basin where it mixes with ground water moving along regional and subregional flow paths.

\section{Alkali Flat-Furnace Creek Ground-Water Basin}

In this basin, ground water is derived from infiltration on Pahute Mesa, Timber Mountain, Shoshone Mountain, and the Grapevine and Funeral Mountains. Additional recharge to this basin occurs as interbasinal ground-water flows across boundaries from Oasis Valley and Ash Meadows. The Alkali Flat-Furnace Creek ground-water basin is divided into four sections (fig. 32): Fortymile Canyon section, Amargosa River section, Crater Flat section, and Funeral Mountains section.

Locally recharged ground water moves toward discharge areas in the southern parts of the basin. Dominant ground-water flow paths appear to mimic surface-water flow. The surface-water flow seem to be structurally controlled along the Amargosa River and Fortymile Wash and in Crater Flat (Grose and Smith, 1983). In the northwestern portions of the basin, subregional ground-water movement is dominantly lateral and downward toward regional flow paths (Czarnecki and Waddell, 1984; Sinton, 1987; and Kilroy, 1991). Near Yucca Mountain, however, gradients are dominantly upward into the volcanic units (Luckey and others, in press). In the southcentral portions of the basin, near the NevadaCalifornia border (fig. 32), regional ground-water movement is dominantly upward from carbonate units into the subregional system and toward discharge areas along the Amargosa River, Carson Slough, and Alkali Flat (Czarnecki and Waddell, 1984; Czarnecki, 1990).

In the southern Amargosa Valley, regional ground-water movements are toward the southwest and south. This ground water may either flow through fractures in the southeastern end of the Funeral 
Mountains and discharge at Furnace Creek or flow southward and discharge at Alkali Flat (Czarnecki and Waddell, 1984; Czarnecki and Wilson, 1991). Once past the springs at Furnace Creek, the ground water flows toward the saltpan and is discharged either by stands of mesquite on the lower part of the Furnace Creek fan or by evaporation from the saltpan.

Ground water that moves along shallow flow paths, but does not discharge at the Amargosa River, Carson Slough, or Ash Meadows, moves southward toward Alkali Flat where it discharges as spring flow and ET. Walker and Eakin (1963) estimated that approximately $1700 \mathrm{~m}^{3} / \mathrm{d}$ of ground water flows past Alkali Flat into the Southern Death Valley subregion.

\section{Southern Death Valley Subregion}

In general, ground water in the Southern Death Valley subregion is derived primarily from infiltration on the Spring Mountains and small inputs from the Kingston and Greenwater Ranges. Additional minor ground-water volumes may flow into this subregion across the boundary from the Alkali Flat-Furnace Creek basin south of Alkali Flat, and across the model boundary from areas south of Salt Spring Hills in Valjean and Shadow Valleys (fig. 33). The subregion contains four sections (fig. 33): Pahrump Valley section, Shoshone-Tecopa section, California Valley section, and Ibex Hills section.

Ground water recharged on the Spring Mountains moves toward Pahrump Valley. Historically, springs discharged at Manse and Bennett Springs along the base of the broad alluvial fans at the foot of the Spring Mountains. Pumping of ground water in the valley has caused these springs to cease to flow. Ground water in the Pahrump Valley section flows along subregional flow paths either to the west toward Stewart Valley and the northern end of Chicago Valley, or to the south-west toward California Valley. Because the Nopah Range is composed of low permeability quartzite rocks in the subsurface (Grose, 1983), it is believed to cause a bifurcation in groundwater flow. Some of the ground water flowing toward the north and west is discharged at Stewart and Pahrump Valley playas. Some of this ground water may also discharge at the southern end of Ash Meadows at Big, Bole, and Last Chance Springs (Winograd and Thordarson, 1975, p. 91; Peterman and Stuckless, 1992, p. 70; Peterman and Stuckless, 1992, p. 712). Ground-water flow that continues toward
Chicago Valley, within the Shoshone-Tecopa section, mixes with ground water flowing from south of Alkali Flat, and ultimately discharges as spring flows and ET in an area between the towns of Shoshone and Tecopa. In the California Valley section, ground water that flows south from Pahrump Valley discharges south of Tecopa at springs along the Amargosa River Canyon in the Sperry Hills and at China Ranch (W.C. Steinkampf, U.S. Geological Survey and W.E. Werrell, National Park Service, written commun., 1996).

Ground water that does not discharge at the Shoshone-Tecopa area may continue flowing to the southwest into the Ibex Hills section to be discharged as spring flow and ET in the Saratoga Springs area which includes adjacent areas of shallow ground water along the floodplain of the Amargosa River. Some additional ground water may enter the basin from Valjean and Shadow Valleys into California Valley and discharge at Saratoga Springs. Small volumes of ground water may continue north past Saratoga Springs to discharge at the Badwater Basin saltpan (fig. 32).

\section{Regional Flow System Water Budget}

Because inflow and outflow volumes are poorly defined for many areas in the Death Valley region, the water budget for the ground-water flow system is difficult to compute. The large size of this regional system precludes the comprehensive and accurate assessment of all inflows to and outflows from the system. Despite this difficulty, several investigators have attempted to estimate water budgets for various parts of the flow system (Walker and Eakin, 1963; Rush, 1968; Malmberg and Eakin, 1962; Glancy, 1968; Malmberg, 1967; Harrill, 1986; Waddell, 1982; Rice, 1984; Harrill and others, 1988; Dettinger, 1989). These investigators used different boundaries to define the various basins in the flow system. Therefore, little, if any, of the data can be compared.

Because the methods for estimating components of the flow system have already been discussed, this section emphasizes the lumped values of the regional ground-water budget. Each component of the budget, such as ET, is defined by a single lumped value even though it may have been calculated originally for separate areas in the basin. 


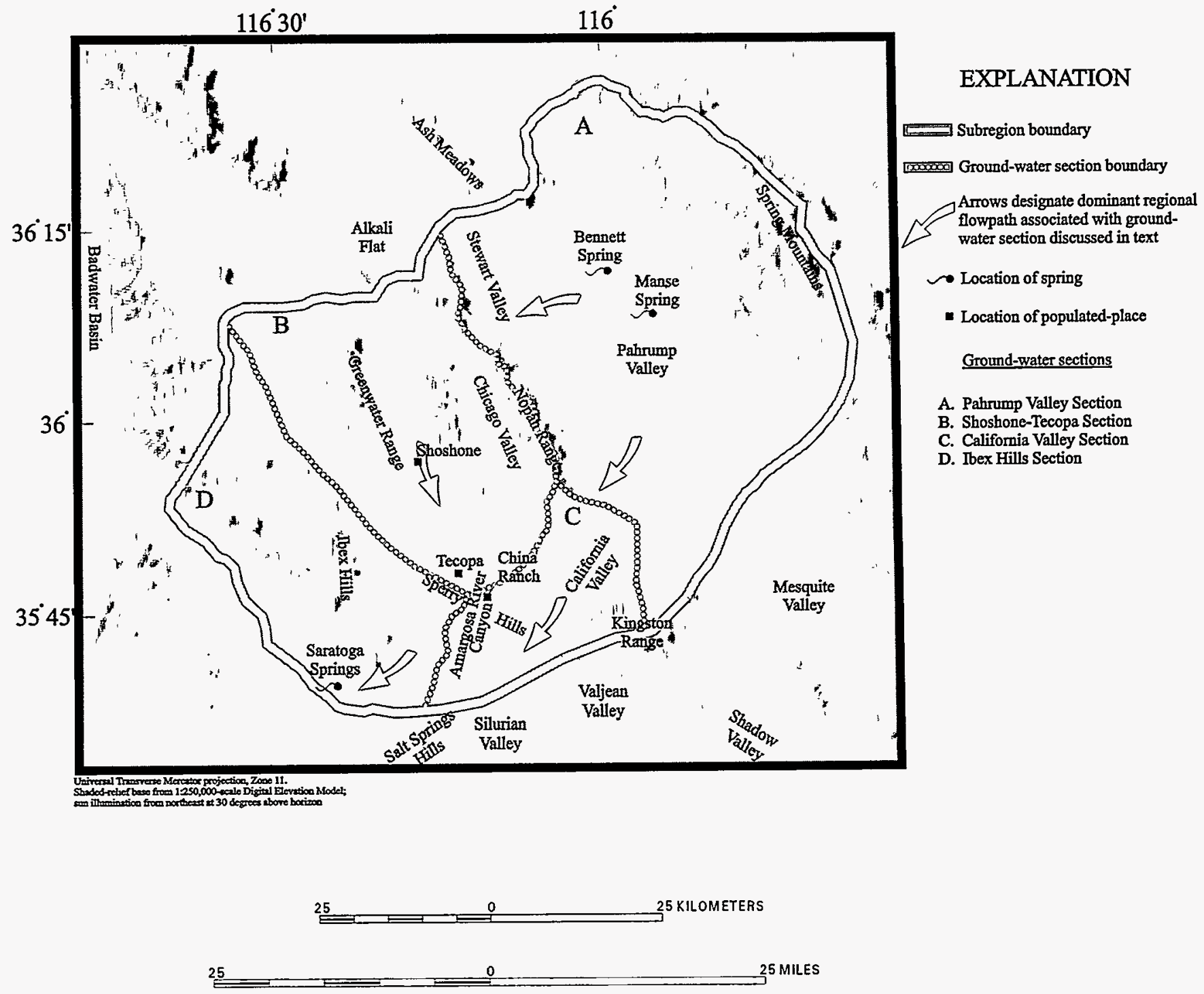

Figure 33. The Southern Death Valley subregion. 
Hollett and others (1991) noted that using this lumped-budget approach permits an overview of the system, but potential interpretation errors may result from slight differences in total inflow or outflow. These sight differences in the regional budget may represent large errors within small areas of the groundwater basin. Because the model computes separate ground-water budgets for small areas of the system, these potential errors frequently become obvious when using a ground-water flow model to analyze the system.

Although individual recharge and discharge component values, including human-induced changes, were determined, errors are inevitable in such estimates. The estimates of inflows to the system that result from interbasinal flows across boundaries are especially problematic. The imbalance between defined inflows and outflows is assigned to net interbasinal flux. The major limitation of this approach is the assumption of steady-state conditions. This assumption requires that the significant historical groundwater withdrawals in the Pahrump and Amargosa Valleys must be offset by reductions in natural discharge or by increased induced inflow from outside the basin.

Table 13 shows a lumped water budget for the Death Valley regional ground-water flow system that is based on the estimates for various inflow and outflow components computed according to previously discussed methods and assumptions. The estimated outflow of $374,000 \mathrm{~m}^{3} / \mathrm{d}$ exceeds the estimated inflow of $344,200 \mathrm{~m}^{3} / \mathrm{d}$ by almost $30,000 \mathrm{~m}^{3} / \mathrm{d}$. This water budget balances within 10 percent of the estimated flux volumes, and appears reasonable given the many uncertainties surrounding the estimates of most components. The difference may be due to the uncertainties surrounding the estimation or assignment of volumes for ground-water pumpage and ET from the Death Valley saltpan.

Considerable uncertainty surrounds the significance of the $89,000 \mathrm{~m}^{3} / \mathrm{d}$ volume of water estimated to be withdrawn by pumpage. If non-equilibrium conditions exist and pumping causes ground water to be withdrawn from storage, then the estimated withdrawal should be counted as a change in storage rather than a component of outflow. Changes in ground water storage within the basin, however, can be determined after further evaluation of the system boundary conditions and aquifer properties.

Table 13. Adjusted regional water budget for the Death Valley regional ground-water flow system

[m3/d, cubic meters per day]

\begin{tabular}{llr}
\hline & & \multicolumn{1}{c}{$\mathbf{m}^{\mathbf{3} / \mathbf{d}}$} \\
\hline INFLOW & Recharge (infiltration) & 312,300 \\
& Flux in & \\
& Pahranagat Valley & 20,000 \\
& Sand Spring Valley & 1,700 \\
& Railroad Valley & 3,400 \\
& Stone Cabin Valley & 3,400 \\
& Ralston Valley & 3,400 \\
TOTAL INFLOW & & 344,200 \\
& & \\
OUTFLOW & Discharge & \\
& (Evapotranspiration) & 148,600 \\
& (Springs) & 125,400 \\
& Flux out & \\
& (Death Valley & 100,000 \\
TOTAL OUTFLOW & saltpan/Saratoga & \\
CHANGE IN STORAGE & Springs) & 374,000 \\
(from pumpage) & & $-89,400$ \\
\hline
\end{tabular}

Rates of ground-water evaporation from the Death Valley saltpan are highly speculative. The estimated discharge volume from the Death Valley saltpan computed by this study (table 2) is nearly three times larger than previous estimates made by Hunt and others (1966) and Miller (1977). This increase results from a larger assumed water evaporation rate $(0.1 \mathrm{~m} / \mathrm{yr})$ from the saltpan estimated by Robinson (1958). Previous estimates were based on smaller assumed rates of evaporation from the saltpan $(0.03 \mathrm{~m} / \mathrm{yr})$ estimated by Hunt and others (1966). The actual evaporation rate cannot be determined without direct field measurements.

\section{NUMERICAL SIMULATION OF REGIONAL GROUND-WATER FLOW}

Development of a 3D flow model allows for the analysis of interactions between relatively shallow local and subregional flow paths and the dominant 
regional flow system controlled by the carbonate aquifer. The resulting Death Valley regional groundwater flow system (DVRFS) model is necessarily large and complex. Calibration of this model by strictly trial-and-error methods was judged to be both ineffective and inefficient; therefore, nonlinear regression methods are used to estimate parameter values that produce the best fit to observed heads and flows. Related methods are used to evaluate model results.

\section{Numerical Modeling Difficulties and Simplifying Assumptions}

Previous studies by Prudic and others (1993) and Waddell (1982) showed that it is difficult to utilize computer models to effectively describe ground-water flow in an area as geographically large and geologically complicated as the Death Valley region. Prudic and others (1993) reiterated that many arguments can be invoked concerning the validity of the assumptions and hydrologic values used in simulating groundwater flow when such complex geology and hydrology are involved.

Inevitably, simplifications and assumptions must be used to adapt the complex conceptual model for numerical simulation. The assumptions and simplifications used to develop the DVRFS model include the following:

1. Ground water in the region flows through fractured volcanic and carbonate rocks, as well as in porous valley-fill alluvium. However, fracture flow simulation is impractical at a regional scale, and, therefore, a porous medium simulation is used. Zones of high hydraulic conductivity are used to account for highly faulted and fractured regions.

2. Hydraulic conductivities within each model cell are assumed to be homogeneous and horizontally isotropic. Thus, features smaller than the grid cells are not represented. This approach is likely to produce reasonable approximations to largescale flow patterns. Small-scale flow paths, however, are not represented.

3. The system can be represented adequately as steady state. Four conditions exist that may violate this assumption. First, the regional flow system still may be undergoing a drying-out sequence following a wetter climate cycle related to the late Pleistocene (Prudic and others, 1993). As a result, current ground-water levels and discharge rates may not be in equilibrium with present-day recharge and interbasinal flux rates. Second, and perhaps more important, ground-water withdrawals by wells for domestic, municipal, mining and irrigation uses are imposing new stresses on the present-day system. This pumpage is derived initially from ground water, from storage, and subsequently from capture of natural discharge. Incorporating pumping in a steady-state model omits the possibility of deriving water from storage, so that water flowing to wells must be offset by capture of natural discharge, that is, reductions in discharge or induced inflow. Although a transient simulation beginning at predevelopment conditions would avoid this assumption, additional assumptions would be needed to define historic pumping levels. In addition, some current water-level data and some spring-flow rates already reflect changes to the system resulting from development, suggesting that the DVRFS may have already adapted to these changes. For example, the springs at Pahrump Valley, including Manse and Bennetts Spring, have ceased to flow in historic time. Third, the flow system experiences seasonal fluctuations that are not simulated. A resulting annual average condition is simulated. Fourth, hydraulic-head, spring-fiow and other data used in model calibration were collected over an interval of many years, and these data are affected by seasonal and yearly changes to the ground-water flow system.

\section{Numerical Model Selection}

The numerical model used in this study is MODFLOWP (Hill, 1992). As documented by Hill (1992), MODFLOWP is an adaptation of the U.S. Geological Survey 3D, finite-difference modular ground-water flow model, MODFLOW (McDonald and Harbaugh, 1988; Hill, 1992) in which nonlinear regression is used to estimate flow-model parameters that result in the best fit to measured hydraulic heads and flows.

MODFLOWP is a block-centered finitedifference code that views a 3D flow system as a sequence of layers of porous material organized in a horizontal grid or array (fig. 34). The horizontal grid 


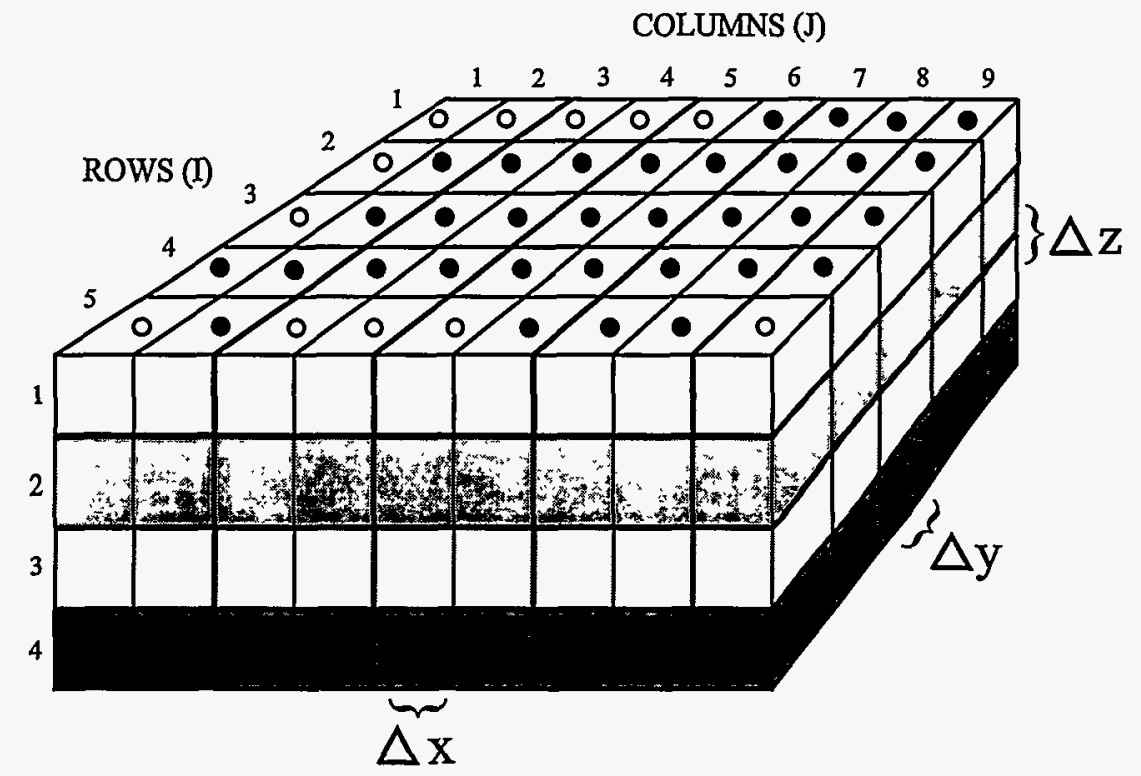

EXPLANATION

O Inactive cells

Active cells

Figure 34. Generic MODFLOWP model grid.

is generated by specifying array dimensions in the $\mathrm{x}$ and $y$ directions. In the DVRFS model, model layers are defined as being confined, so that layer thickness is constant. Although the top layer in the simulated flow system is clearly unconfined, defining its thickness from the developed potentiometric-surface map and representing it as confined produces a good approximate thickness and is much more efficient numerically.

Flow between cells in each model layer is controlled by user-supplied transmissivity values. Flow between model layers is controlled by usersupplied values of a vertical transmission or leakage term, known as VCONT (McDonald and Harbaugh, 1988, p. 5-39). The number of VCONT arrays required for simulation is one less than the number of model layers (fig. 35).

The remainder of the model inputs describing boundary conditions, recharge, ET, spring flow, and well discharge are specified using arrays or lists of row-column cell location. The model calculates the heads from inputs to, outputs from, and flow between nodes. With the preconditioned conjugate-gradient iterative solver used (Hill, 1992), the model recalculates the head distribution in each node of each layer until head changes between solver iterations and cellby-cell budget errors drop below a user-specified value.

\section{Nonlinear Regression Objective Function}

Nonlinear regression estimates parameter values by finding the values that minimize the weighted sum of squared residuals objective function, $\mathrm{S}(\underline{b})$, which is calculated as:

$$
S(\underline{b})=\left(\underline{y}-\underline{y}^{\prime}\right)^{T} \underline{W}\left(\underline{y}-\underline{y}^{\prime}\right)
$$

where,

$\underline{b}$ is an $n p \times 1$ vector containing parameter values;

$n p$ is the number of parameters estimated by regression;

' $\underline{y}-y^{\prime}$ are $n \times 1$ vectors with elements equal to observed and simulated (using $\underline{b}$ ) values respectively (for the DVRFS model, the observed and simulated quantities are hydraulic heads and spring flows); 


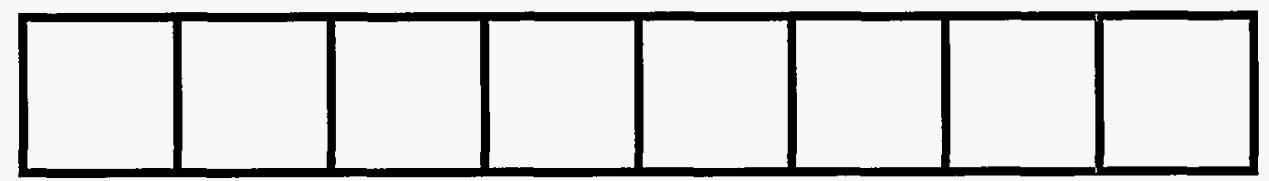

Hydraulic

Conductivity

Layer \#1

VCONT

Layer \#1

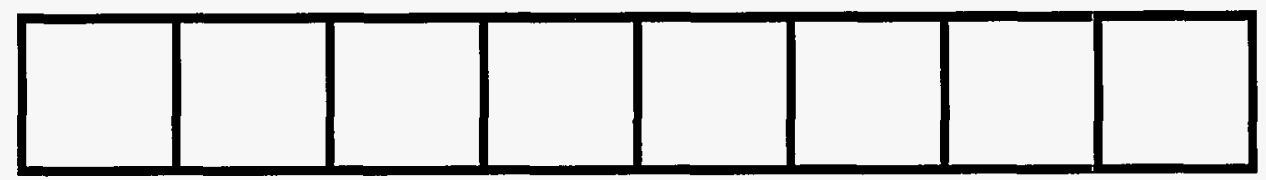

Hydraulic Conductivity

Layer\#2

VCONT

Layer \#2

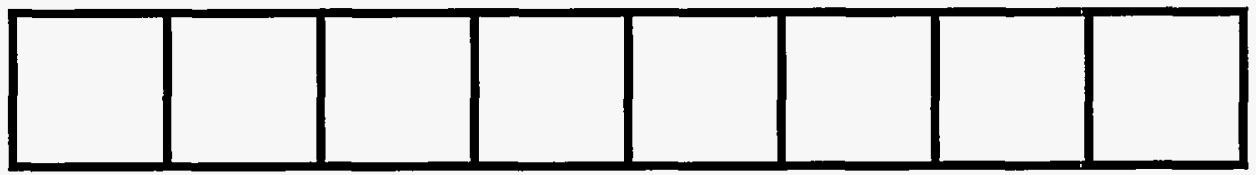

Hydraulic

Conductivity

Layer \#3

Figure 35. Example of VCONT array organization.

$\underline{y}-\underline{y}^{\prime}$ is a vector of residuals, defined as the observed minus simulated values;

$n$ is the number of measured and simulated hydraulic heads and flows;

$\underline{W}$ is an $n \times n$ weight matrix; and

$T$ superscripted indicates the transpose of the vector.

For the DVRFS model, the weight matrix is diagonal, with the diagonal entries equal to the inverses of subjectively determined estimates of the variances of the observation measurement errors. This weighting will result in parameter estimates with the smallest possible variance if (1) the estimated variances and the model are accurate, (2) the model is effectively linear, or (3) the number of observations is asymptotically large (Bard, 1974). Instead of variances, MODFLOWP permits the designation of standard deviations or coefficients of variation from which the variances are calculated. These indicators of measurement precision are determined based on an analysis of likely measurement error. In MODFLOWP, initial parameter values are assigned and then are changed using a modified Gauss-Newton method such that equation (1) is minimized. The resulting values are called optimal parameter values. This procedure is repeated for each conceptual model considered.

\section{Parameter Definition}

Parameters may be defined to represent most physical quantities of interest, such as hydraulic conductivity and recharge. MODFLOWP allows these spatially distributed physical quantities to be represented using zones over which the parameter is constant, or using more sophisticated interpolation methods. In either case, multipliers or multiplication arrays can be used to modify parameter values in a known way.

\section{Parameter Sensitivities}

As part of the regression, sensitivities are calculated as: $\partial y_{i}^{\prime} / \partial b_{j}$, the partial derivative of the simulated hydraulic head or flow, $y_{i}^{\prime}$, with respect to the $\mathrm{jth}$ estimated parameter, $b_{\mathrm{j}}$, using the sensitivityequation method (Hill, 1992). Because the groundwater flow equations are nonlinear with respect to 
many parameters, sensitivities calculated for the same parameter for different sets of parameter values will be different.

Besides being used in the regression calculations, sensitivities are useful to the modeler because they reflect how important each measurement is to the estimation of each parameter. The composite scaled sensitivity (CSS) is a statistic which summarizes all the sensitivities for one parameter, and, therefore, indicates the cumulative amount of information that the measurements contain toward the estimation of that parameter. Because they are dimensionless, composite scaled sensitivities can be used to compare the amount of information provided by various types of data for different types of parameters. Composite scaled sensitivity for parameter $j, C S S_{j}$, is calculated as:

$$
C S S_{j}=\left\{\left[\sum_{i=1, n} w_{i}\left(\partial y_{i}^{\prime} / \partial b_{j}\right)^{2} b_{j}^{2}\right] / n\right\}^{1 / 2}
$$

Parameters with large CSS values relative to those for other parameters are likely to be easily estimated by the regression; parameters with smaller CSS values may be more difficult to estimate. For some parameters, the available measurements may not provide enough information for estimation. In this circumstance, the parameter value will need to be set by the modeler, or more head and flow measurements will need to be added to the regression. Parameters with values set by the modeler are called unestimated parameters. Composite scaled sensitivities calculated for different sets of parameter values will be different, but they are rarely different enough to indicate that a previously unestimated parameter can subsequently be estimated.

An alternative to setting a parameter value is to use prior information on the parameter. This alternative is especially attractive if the parameter is important to model predictions because it allows measures of uncertainty in model predictions, such as confidence intervals, to reflect uncertainty in the unestimated parameter. Prior information was not used in the calibration of the DVRFS model but can be included later as needed for predictions.

Confidence intervals on the estimated parameter values can be calculated using linear (first-order) theory with sensitivities calculated for the optimal parameter values. Parameters with a large CSS tend to have small confidence intervals. Confidence intervals are useful when trying to decide how many parameters are needed to represent, for example, the hydraulicconductivity distribution. If, for example, four zones are considered to be important, but the regression yields estimates that are within the confidence intervals related to two or more of the zones, it is likely that fewer zones are adequate. If the regression using fewer zones yields a similar model fit to the measurements, the available measurements are insufficient to distinguish between a model with four zones and one with fewer zones.

\section{Model Construction}

The 3D hydrogeologic data sets describing the DVRFS were discretized to develop the input arrays required for MODFLOWP. Because the various $3 D$ hydrogeologic data sets were developed at grid cell resolutions ranging from 100 to $500 \mathrm{~m}$, their discretization to a common, larger grid cell resolution inevitably results in further simplification of the flowsystem conceptual model and hydrogeologic framework model. This resampling and simplification of the 3D hydrogeologic data sets was apparent in (1) definition of the model grid, (2) assignment of boundary conditions, (3) definition of model parameters, and (4) organization of observation data for nonlinear regression.

\section{Grid Definition}

The model used consists of 163 rows, 153 columns and 3 layers. The 74,817-cell model is oriented exactly north-south (fig. 36). The lower, leftcorner origin of the grid was located at UTM coordinates $(X ; Y=440,340 ; 3,944,782)$. Grid discretization along both rows and columns was set to $1,500 \mathrm{~m}$. The three model layers represent hydrogeologic units at $0-500 \mathrm{~m}, 500-1,250 \mathrm{~m}$, and 1,250-2,750 $\mathrm{m}$ below the interpreted water table; they are 500,750 , and $1,500 \mathrm{~m}$ thick. The first and second model layers are interpreted as simulating local and subregional flow mostly within valley-fill alluvium, volcanic rocks and shallow carbonate rocks; the third layer is interpreted as simulating regional flow in the volcanic, carbonate and clastic rocks. The hydrogeologic framework was simplified to three layers because of the apparent uncertainty associated with the hydrogeologic interpretation in the region. The use of only one 


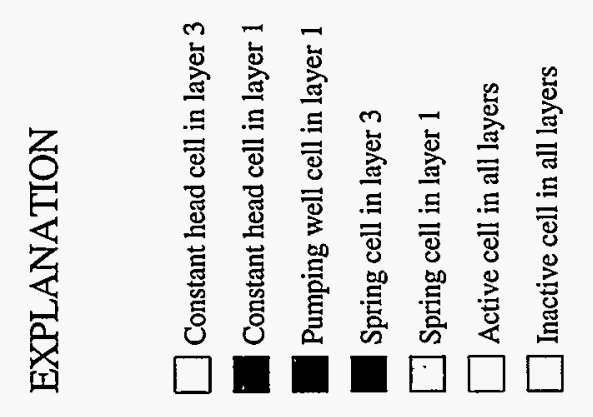

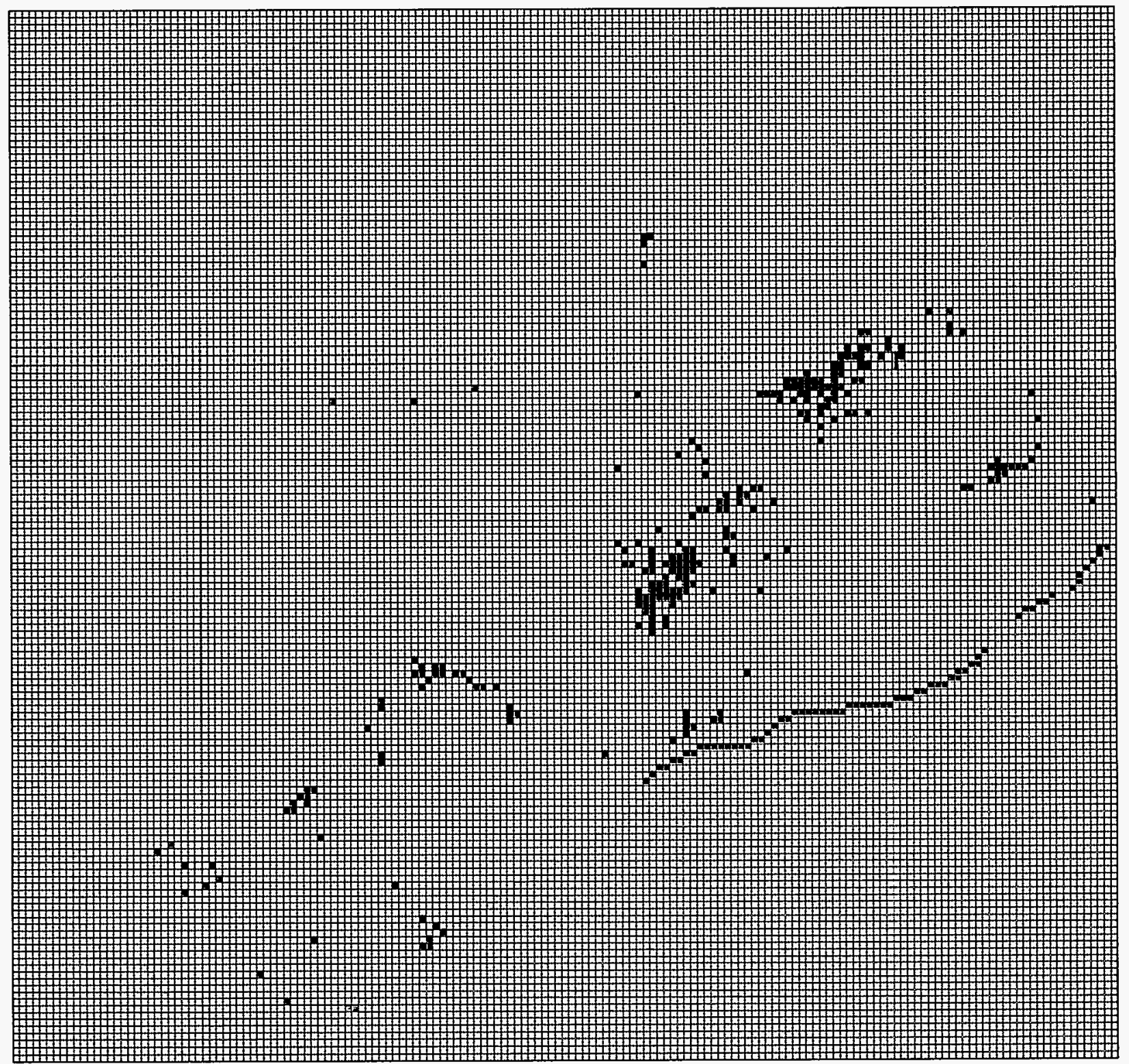


model layer to represent each of the local, subregional and regional flow paths may potentially result in model error in areas of significant vertical flow, particularly if the vertical flow component is somewhat complicated.

\section{Boundary Conditions}

The model boundaries used in this study are somewhat smaller in area than those for the Death Valley regional ground-water flow system (fig. 29). At Death Valley, a flux boundary is assigned to simulate flow out of the system as ET. This convention is similar to previous models of the basin (Waddell, 1982; Rice, 1984; Prudic and others, 1993).

The extent of active cells, shown in figure 36 , is the same in all layers. In layer one, all lateral boundaries were designated as no-flow except along the western boundary at Death Valley, where constant head boundaries are designated at Cottonball, Middle and Badwater Basins, and Saratoga Springs. Head values along this boundary were defined using the potentiometric-surface map developed for this study and reflect the nearly perennial ponds supported by ground-water flux out of the system. In layer two, all lateral boundaries were designated as no flow because at these depths no flow is believed to cross the lateral boundaries. In layer three, the lateral boundaries were designated as no-flow except at four locations along the northern and eastern boundaries (fig. 36). These were assigned constant-head values to reflect possible or perceived interconnections along buried high transmissivity structural features with regional flow paths in adjacent valleys outside the model domain. The head values were selected to correspond to measured water levels, spring levels, and/or lakesurface altitudes in these valleys.

\section{Model Parameter Definition}

\section{Flow Parameters}

The cellular data structure of the 3D hydrogeologic framework model is easily reconfigured for use by MODFLOWP. Stratamodel SGM includes a resampling function that produces parallel slices from the 3D framework model. This function allows for the immediate conversion of the 3D hydrogeologic framework model into a series of 2D layers required by the finite-difference representation used by MODFLOWP. Three layers were defined to represent the material properties of hydrogeologic units at
$0-500 \mathrm{~m}, 500-1,250 \mathrm{~m}$, and 1,250-2,750 $\mathrm{m}$ below the water table. Thus, the parallel slices are not flat; they reflect the form of the water table. Each layer was reformatted in a 2D GIS map.

Aquifer properties vary considerably within each of the 10 hydrogeologic units in the framework model, but were lumped into a limited number of categories for the simulation. The subsurface materials of the hydrogeologic framework model were initially classified into eight rock conductivity units (RCU's). Each RCU represents mean hydraulic conductivity of several subsurface materials whose interpreted characteristics, such as rock type, depth, and degree of fracturing resulted in very similar hydraulic conductivity values.

Because each of the three model layers contained several hydrogeologic framework model units, multiple RCU's were associated with each finite-difference model cell. The RCU occupying the largest volume in the finite-difference flow model cell was assigned to each cell. To reduce the number of parameters that would need to be estimated, the layer maps were reclassified by combining the eight RCU's into four hydraulic-conductivity zones (K-zones) representing large $(\mathrm{K} 1)$, moderate $(\mathrm{K} 2)$, small (K3) and very small (K4) hydraulic-conductivity values (fig. 37). The resulting $\mathrm{K}$-zones were not contiguous; each $\mathrm{K}$-zone included cells distributed throughout the model (figs. 38 through 40). The 50th percentile $\mathrm{K}$-value for each of the zones shown in figure 40 was used for the initial hydraulic conductivity values assigned to each $\mathrm{K}$-zone. As mentioned previously, horizontal isotropy was applied because dominant fracture directions are different in different parts of the model domain.

Transmissivity values for the model layers were calculated by multiplying the applicable K-zone values by layer thickness. VCONT arrays were not externally generated. Instead, MODFLOWP calculated the VCONT values using layer transmissivities and thickness and a parameter (ANIV) which specifies the vertical anisotropy (horizontal:vertical) of each model layer. Thus, the vertical hydraulic conductivity for each cell was calculated.as horizontal hydraulic conductivity divided by the applicable ANIV parameter value; VCONT values were calculated as described by McDonald and Harbaugh (1988, p. 5-13). For this model, two ANIV parameters were specified: (1) ANIV1 which represents the vertical anisotropy of model layers one and two, and 
(2) ANIV3 which represents the vertical anisotropy of layer 3 .

\section{Evapotranspiration}

ET is expressed in terms of a linear function based on three variables: (1) land-surface altitude, (2) extinction depth, and (3) maximum ET rate (McDonald and Harbaugh, 1988, p 10-1 to 10-8). Each of these variables was specified from GIS-based data sets including the DEM and the ET areas map (fig. 23). Extinction depths were assigned for each unique ET area based on information about plant type and ranged in value from 0 to $15 \mathrm{~m}$. Each of these data sets was resampled to a $1,500 \mathrm{~m}$ grid. Areas where ET cells were designated are shown in figure 41 . The spatial variability of maximum ET rates is described in a multiplication array in MODFLOWP. This array is associated with a parameter (ETM) which is a multiplication factor that may be adjusted during parameter estimation.

Since the Death Valley saltpan was simulated as a constant head boundary, it is not included as part of the ET array (fig. 36). The constant head boundary maintains heads at a specified level in each designated cell. For purposes of this report the specified head is set equal to the water-table altitude at the edge of the saltpan. This level is better measured than evaporation rates on the saltpan and permits water to discharge from model layer 1.

\section{Recharge}

To define ground-water recharge, the recharge potential map (fig. 25) was resampled to a $1,500 \mathrm{~m}$ grid and reclassified into an array for MODFLOWP containing four zones associated with high ( $\mathrm{RCH} 3$ ), moderate ( $\mathrm{RCH} 2$ ), low ( $\mathrm{RCH} 1$ ), and no ( $\mathrm{RCH} 0$ ) recharge potential parameters (fig. 42). Each parameter defines a percentage factor that represents the amount of average annual precipitation that infiltrates. Average annual precipitation is defined by a multiplication array in MODFLOWP. These zone and multiplication arrays, therefore, along with the parameter values, define the recharge distribution for the model area. In initial parameter-estimation runs, recharge rates based on fixed percentages were lumped into a single recharge parameter ( $\mathrm{RCH}$ ) for simplicity.

\section{Springs}

The regional springs data set was utilized to specify the row-column locations of spring nodes (fig. 36). All but three groups of springs were thought

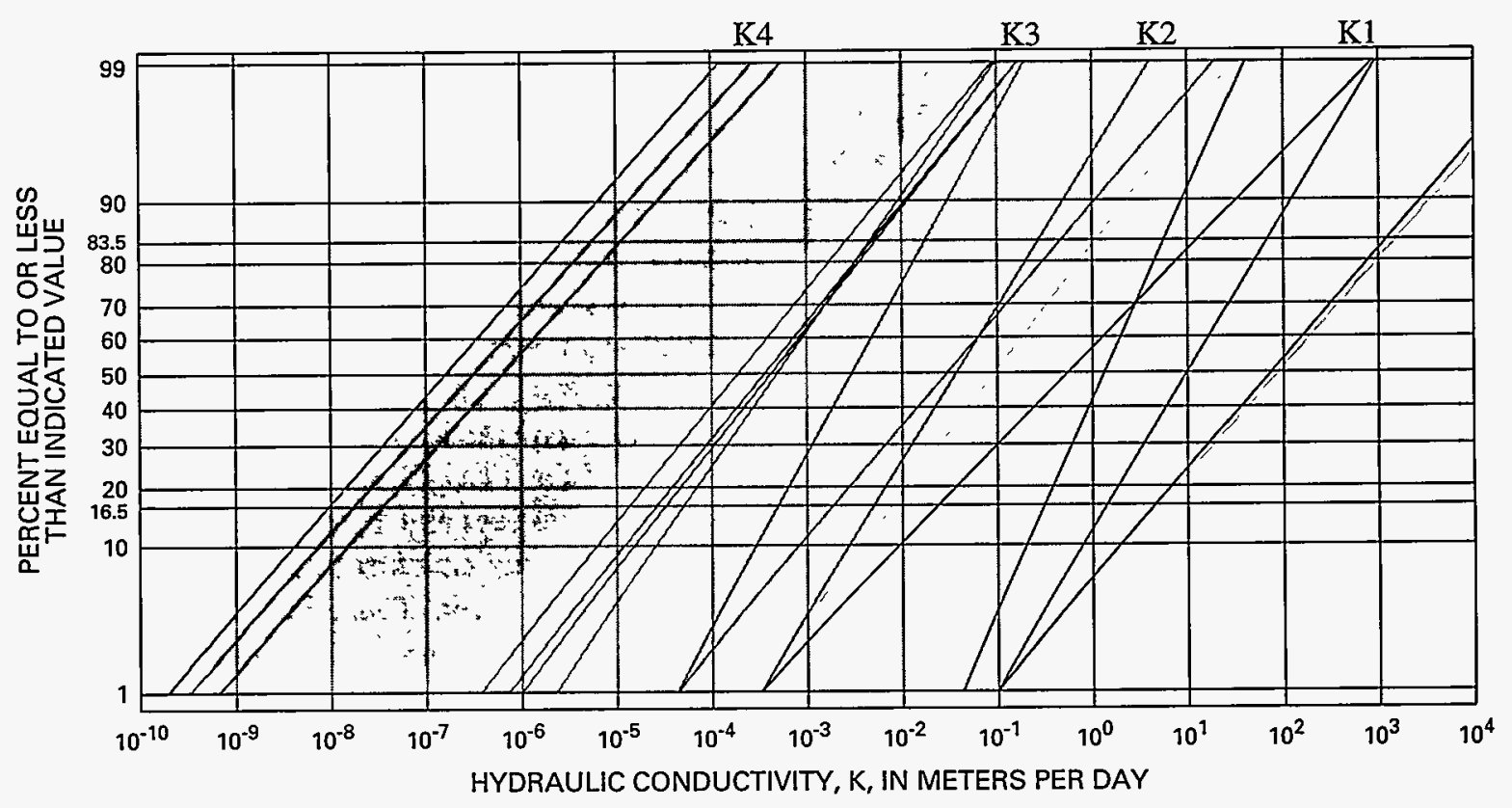

Figure 37. Hydraulic conductivity distributions for $\mathrm{K} 1, \mathrm{~K} 2, \mathrm{~K} 3$, and $\mathrm{K} 4$. 

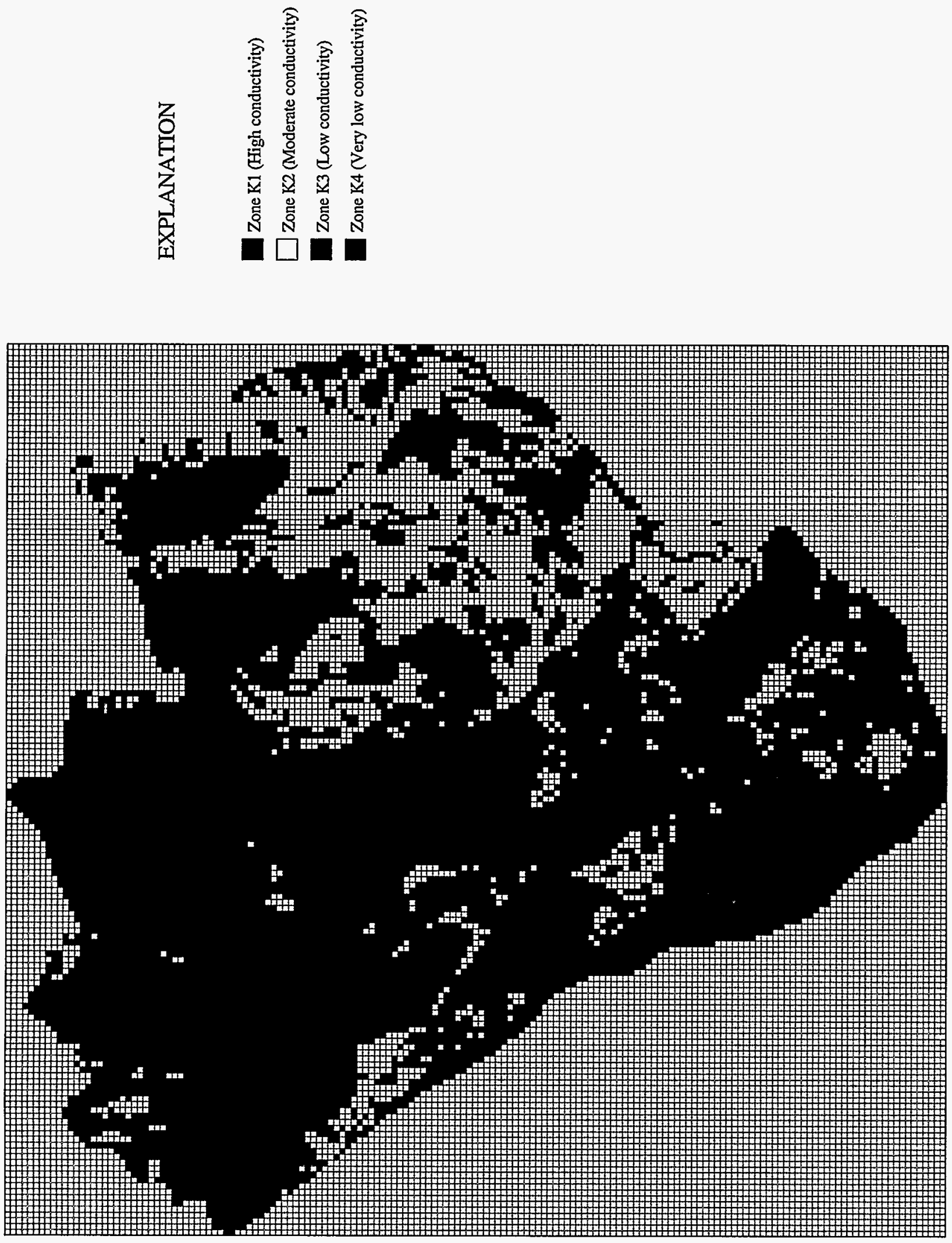

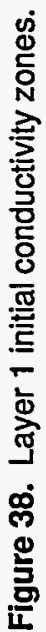



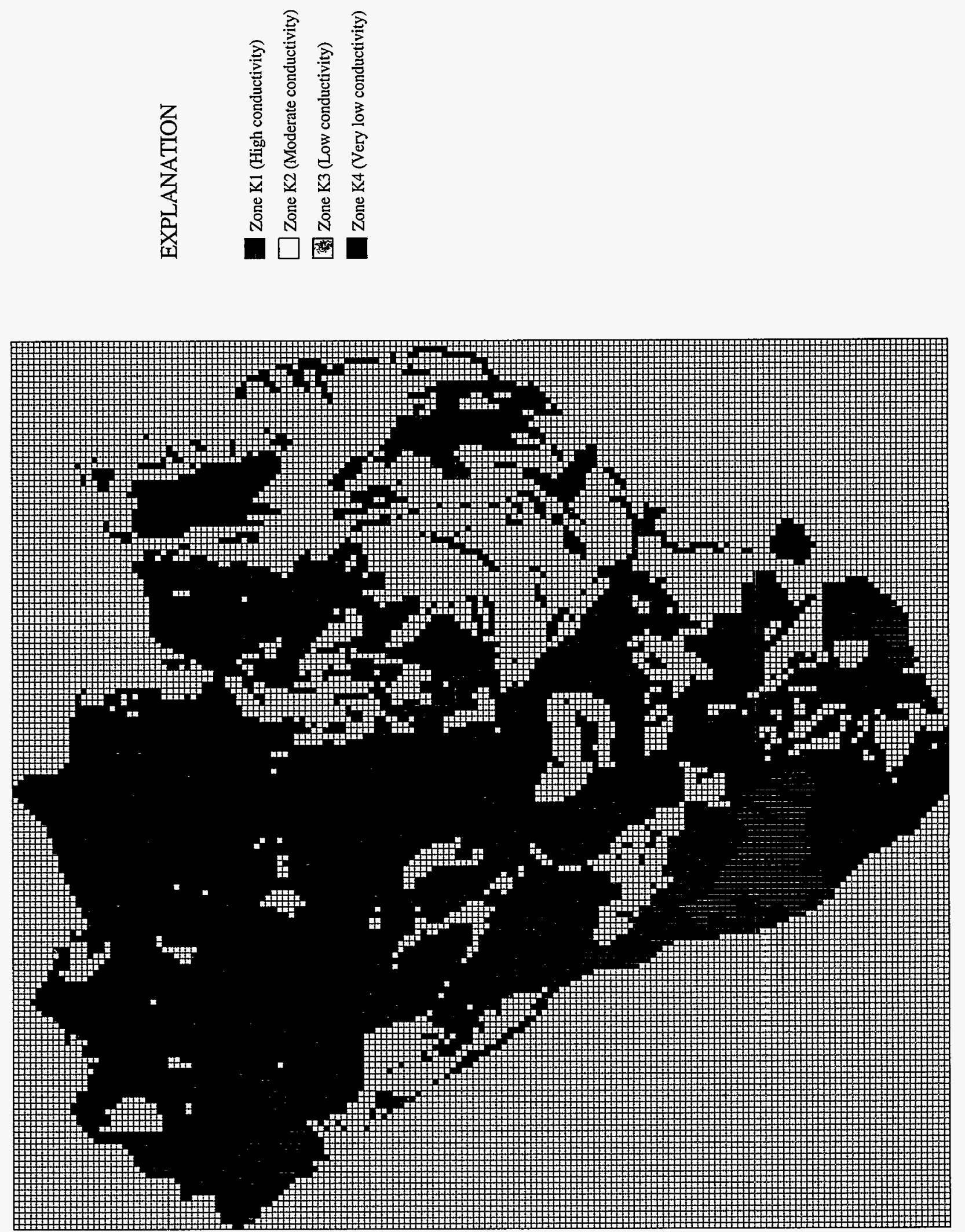

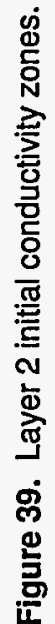

80 Hydrogeologic Evaluation and Numerical Simulation of the Death Valley Regional Ground-Water Flow System, Nevada and California 

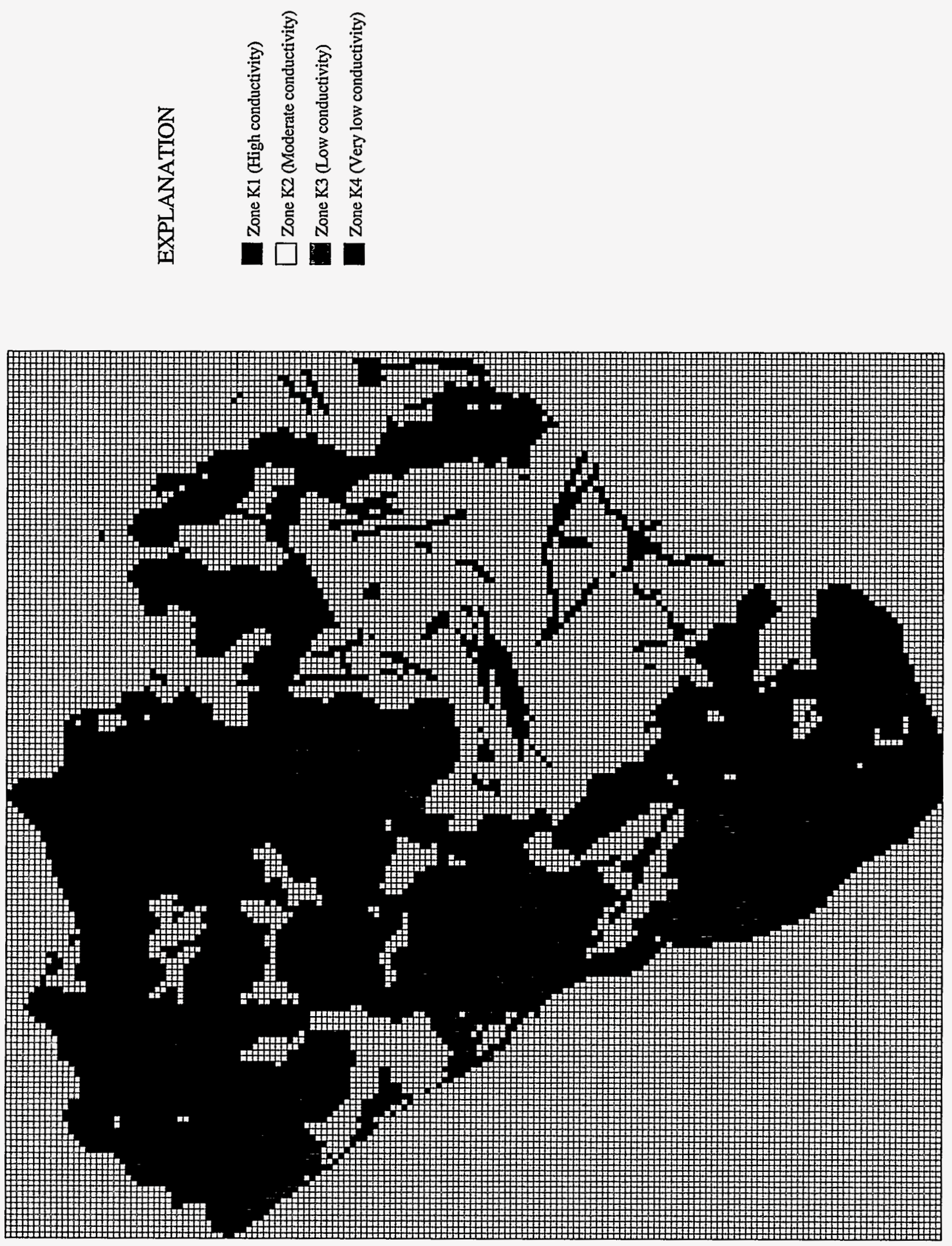

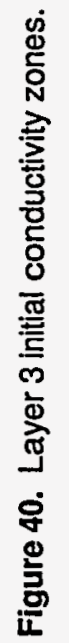




$$
\text { 善 }
$$

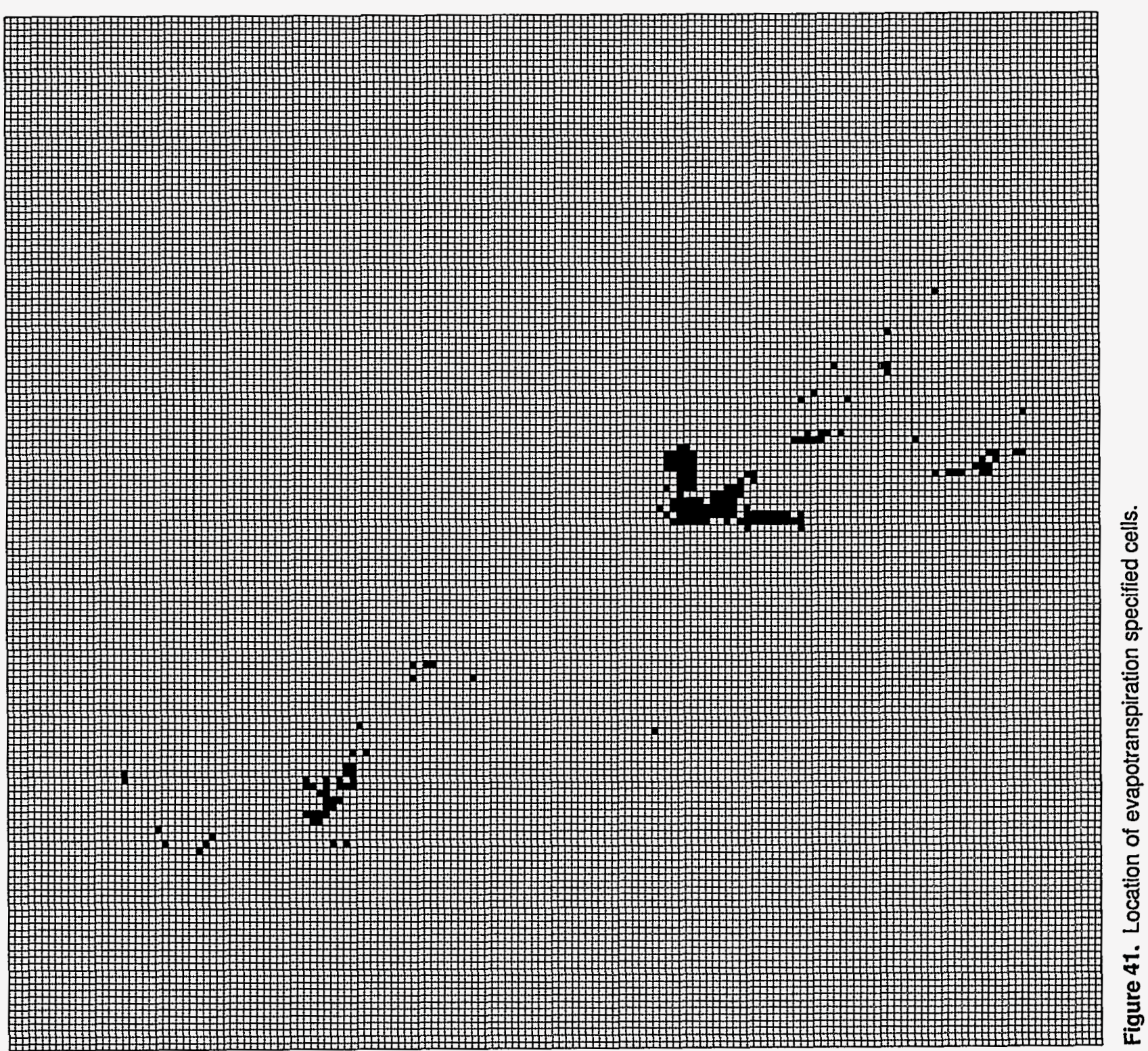

82 Hydrogeologic Evaluation and Numerical Simulation of the Death Valley Regional Ground-Water Flow System, Nevada and California 

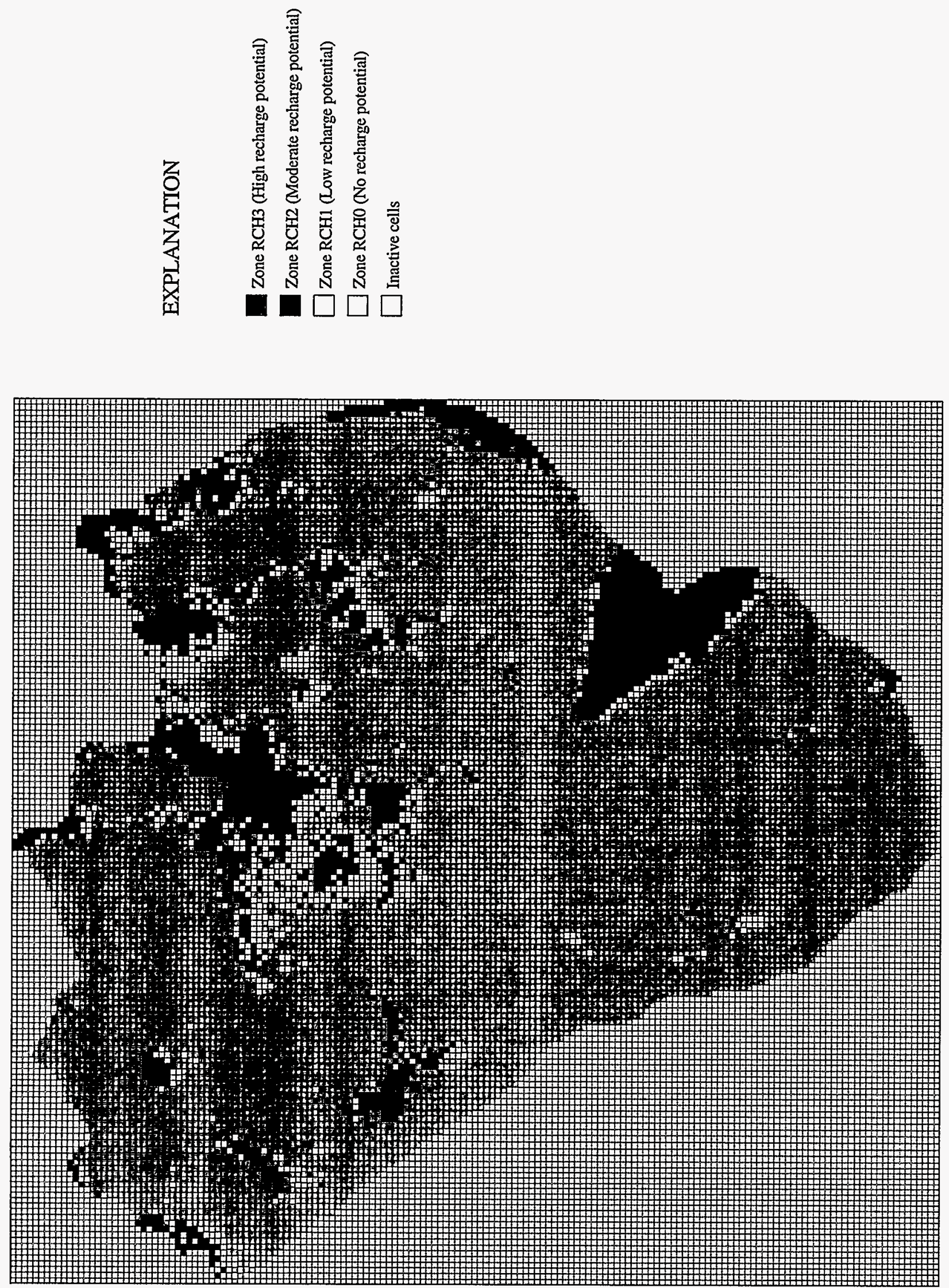

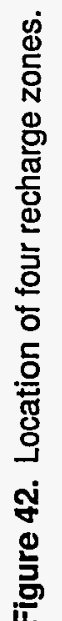


to discharge from deep regional flow paths, and were, therefore, assigned to layer three. Sand Springs, Indian Springs and Cactus Springs are interpreted as discharging from more localized flow paths in model layer 2. Springs were specified using the general-head boundary package for which the altitude and conductance of spring orifice are assigned. Because the conductance term is poorly known, springs were grouped according to geographic location and a conductance parameter (GHB) assigned for each of the groups of springs (table 14). The difference of conductance values for springs reflects the drastically different materials through which springs discharge. In earlier model runs, values for conductance were estimated; however, as calibration proceeded, these parameters were fixed and not estimated.

Table 14. Final conductance parameters (GHB) for large volume spring discharge (in square meters per day)

\begin{tabular}{lc}
\hline \multicolumn{1}{c}{ Spring } & Assigned value \\
\hline Ash Meadows & 100.0 \\
Grapevine Springs & 11.0 \\
Oasis Valley & 1.7 \\
Furnace Creek & 5.00 \\
Tecopa & 0.1 \\
\hline
\end{tabular}

\section{Pumping Wells}

The well package was used to simulate the amount of ground-water pumped from the system. Because most of the water pumped from the wells is relatively shallow ground-water, all pumping wells were located in the first model layer. The water-use well data set was used to specify the grid-cell locations and approximate ground-water volumes being removed from the model domain. Approximate pumpage rates probably exceed actual values, so two parameters were assigned to make it easy to modify simulated pumpage. The two parameters are multiplication factors representing the percentage of pumpage included in the simulation. WEL2 represents the parameter applied to the Pahrump Valley area, which bears the majority of ground-water withdrawal in the region. WEL1 represents the parameter applied to the remainder of the model domain. These parameters were not estimated because their inclusion created an unrealistic source of recharge to the model. That is, when regression was applied, the wells became a source of water instead of discharge locations.

\section{Summary of Defined Parameters}

Although 18 parameters were initially defined for the DVRFS model (table 15), not all parameters were estimated. Composite scaled sensitivities (CSS

Table 15. Initial defined parameters and initial values for the DVRFS model

[m/d, meters per day; $\mathrm{m}^{2} / \mathrm{d}$, square meters per day]

\begin{tabular}{llc}
\hline Parameter & \multicolumn{1}{c}{ Description } & Initial value \\
\hline K1 & High hydraulic conductivity & $0.1 \mathrm{~m} / \mathrm{d}$ \\
K2 & Moderate hydraulic conductivity & $0.01 \mathrm{~m} / \mathrm{d}$ \\
K3 & Low hydraulic conductivity & $0.001 \mathrm{~m} / \mathrm{d}$ \\
K4 & Very low hydraulic conductivity & $0.0001 \mathrm{~m} / \mathrm{d}$ \\
ANIV1 & Vertical anisotropy for layers 1 and 2 & 1.0 \\
ANIV3 & Vertical anisotropy for layer 3 & 10.0 \\
ETM & Maximum evapotranspiration rate factor & 1.0 \\
RCH0 & Area of no recharge potential & 0.0 \\
RCH1 & Area of low recharge potential & 0.03 \\
RCH2 & Area of moderate recharge potential & 0.07 \\
RCH3 & Area of high recharge potential & 0.20 \\
GHBa & Spring conductance for Ash Meadows & $100 \mathrm{~m}^{2} / \mathrm{d}$ \\
GHBg & Spring conductance for Grapevine Springs & $10 \mathrm{~m}^{2} / \mathrm{d}$ \\
GHBo & Spring conductance for Oasis Valley & $10 \mathrm{~m}^{2} / \mathrm{d}$ \\
GHBf & Spring conductance for Furnace Creek & $100 \mathrm{~m}^{2} / \mathrm{d}$ \\
GHBt & Spring conductance for Tecopa & $1 \mathrm{~m} / \mathrm{d}$ \\
WEL2 & Ground-water pumpage (Pahrump Valley) & 0.5 \\
WEL1 & Ground-water pumpage multiplied for model domain & 1 \\
& (except Pahrump Valley) & \\
\hline
\end{tabular}

84 Hydrogeologic Evaluation and Numerical Simulation of the Death Valley Regional Ground-Water Flow System, Nevada and Callfornia 
values) for some of these parameters, calculated for the initial model, are shown in figure 43. During calibration, CSS values were often used to determine the least sensitive parameters, which were then often omitted from the regression. Several parameters with small CSS values were assigned values during most or all of the calibration.

\section{Observation Data}

Measured hydraulic heads and spring discharges were used by MODFLOWP during parameter estimation to provide values to define the objective function for the model simulation.

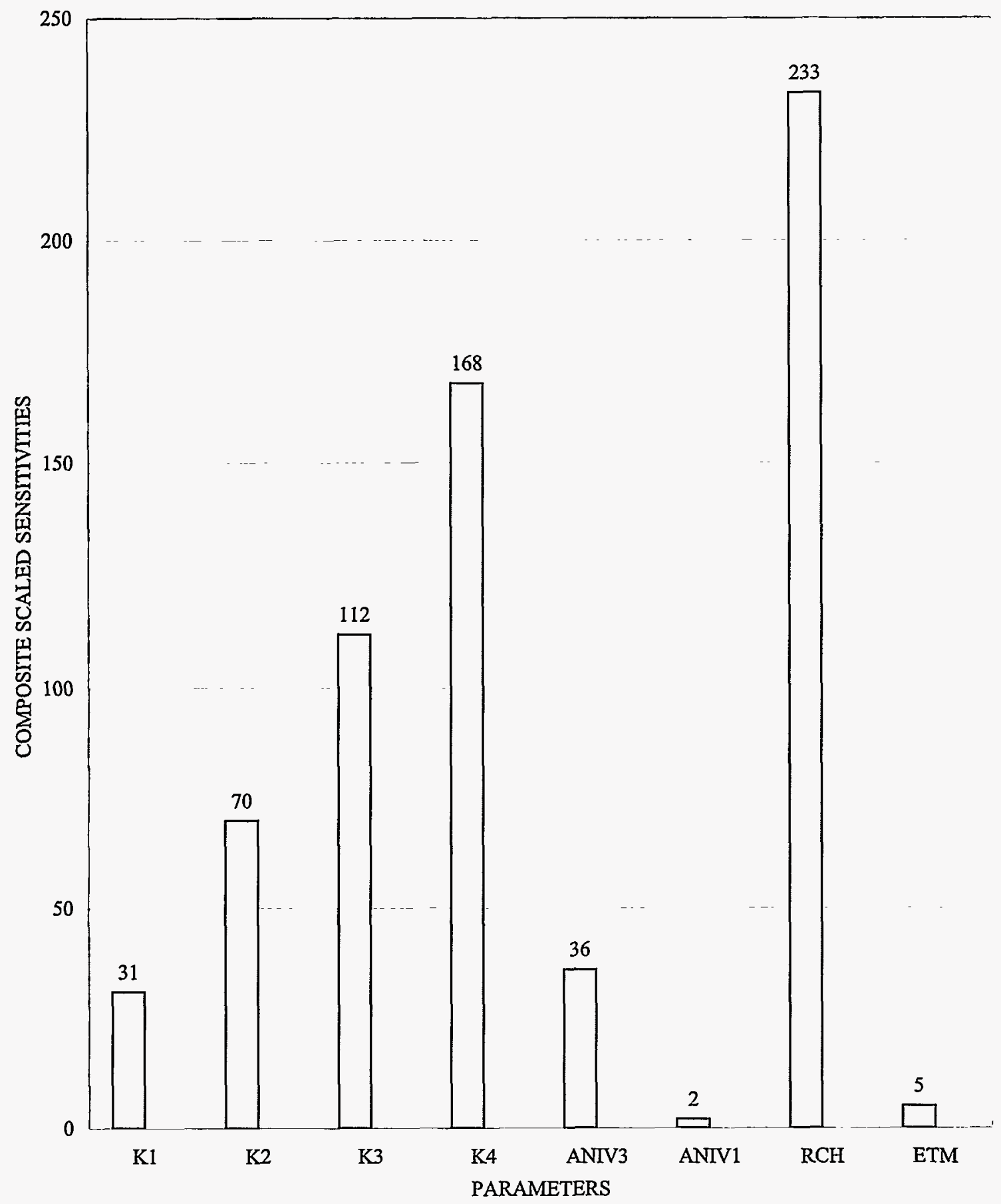

Figure 43. Composite scaled sensitivities of initial model. 


\section{Hydraulic-Head Observations}

For each hydraulic-head observation, the following quantities need to be specified: measured head value, well location, a standard deviation describing the precision of the water-level measurement, and the model layers that are included in the contributing interval of the well. Three issues of hydraulic-head data specification require additional explanation. These are: (1) the existence of multiple measured heads located in a single finite-difference cell; (2) wells open through more than one model layer; and (3) determination of the standard deviation for each observed head.

Water levels for multiple wells in the same model cell and affecting the same layer were averaged to develop a single composite water level for that cell and layer. Generally, composite water levels represent a variation of no more than $25 \mathrm{~m}$ from any one measurement. A total of 500 composite water-levels were ultimately used in the DVRFS model.

Wells were segregated according to depth. Thirty-four wells were completed to depths greater than $1,250 \mathrm{~m}$ below the water table. Another 137 wells were completed to depths between 500 and $1,250 \mathrm{~m}$ below the water table. The remaining 1,970 wells were completed to depths associated with layer 1 . Water levels measured from depths of less than $500 \mathrm{~m}$ below the water table were designated as being 100 percent representative of hydraulic head in layer one cells. For wells completed in layers 2 and 3, the proportional contribution of each layer was calculated using the product of well length and initial estimates for transmissivity for each layer. Simulated water levels for the well were calculated as the sum of the product of proportional contribution and the hydraulic head for each layer.

An assumed standard deviation of $10 \mathrm{~m}$ was used to describe the precision of most of the waterlevel measurements, and therefore, to calculate the weighting described in equation (1). A value of $10 \mathrm{~m}$ seemed appropriate given the lengthy time frame over which the heads were measured, and the range of heads that occurred at cells where multiple heads were available. Some wells located in large hydraulic gradient areas and in areas where the hydraulic-head observations may have been representative of perched conditions were assigned a standard deviation of $30 \mathrm{~m}$. As discussed later, these standard deviations were modified during calibration; final standard deviations range from 10 to $250 \mathrm{~m}$; the largest standard deviation values occurred in large hydraulic gradient areas where the head change over one $1,500 \mathrm{~m}$ cell-width exceeded $300 \mathrm{~m}$.

\section{Spring-Flow Observations}

For each spring-flow observation, spring discharge, spring location, and a coefficient of variation describing the measurement accuracy of the flow were specified. When several springs occurred in a given model cell, an aggregate spring flow for these springs was specified. A total of 63 spring flow measurements were used in model calibration. A coefficient of variation of 10 percent was used to represent the precision of most of the spring discharges measurements. A larger 100 percent coefficient of variation was used for a few small springs that lacked historical discharge measurements.

\section{Model Calibration}

During calibration, a number of conceptual models were evaluated using the regression methods in MODFLOWP. A best fit to hydraulic-head and fiow observations was calculated for each conceptual model. Evidence of model error or data problems were investigated after each model run. These analyses were used in conjunction with independent hydrogeologic data to modify, and hopefully improve, the existing conceptual model, observation data sets, and weighting. No modifications were made simply to improve model fit; supporting independent hydrogeologic criteria were also needed before modifications were made.

\section{Conceptual Model Variations}

Three major types of conceptual model variations were evaluated to test those components of the conceptual model about which the least is known. These modifications included changes to (1) the location and type of flow system boundary conditions, (2) the extent of recharge areas, and (3) the configuration of hydrogeologic framework features. For each change in the conceptual model, a new set of parameters was estimated using MODFLOWP and the resulting new simulated heads and flows were compared with the observed values. Only those conceptual model changes contributing to significant 
( $>10$ percent) improvement in model fit, as indicated by a reduction in the sum of squared errors (eq. 1), were retained in the final optimized model. Variations in hydrogeologic framework interpretation contributed most to improving the numerical model fit.

\section{Location and Type of Boundary Conditions}

The location and type of flow system boundaries were adjusted in the north and northeast parts of the model area (fig. 36) to test the premise that the regional flow system could be receiving interbasinal flux from adjacent basins. Although water-level data exist adjacent to the model boundaries, considerable uncertainty remains concerning the existence of such fluxes and their volumes.

Modification to the numerical model involved increasing or decreasing the size of the constant-head boundaries, moving the locations of the boundaries to different model layers, and adding new constant-head boundaries to the northeast. In general, these modifications provided very clear results. The optimal location for the constant-head boundaries used to simulate interbasinal flux conditions was the third layer. Locating the constant-head boundaries in the upper layers of the model often led to extremely large deviations from observed heads.

The most appropriate boundary conditions between Sand Spring Valley and Emigrant Valley were evaluated. Simulating a constant-head boundary in this region instead of a no flow boundary resulted in extremely large residuals for heads (100 $\mathrm{m}$ too high) in the northern part of the model domain, and large residuals for spring flows (simulated flows 50 percent too large) at both Ash Meadows and Furnace Creek Ranch. As a result, this boundary was redefined as no flow boundary. The constant-head boundaries at Railroad, Stone Cabin and Ralston valleys, however, were needed to simulate spring flows close to measured flow at both Grapevine Springs and Oasis Valley. The constant-head boundary at Pahranagat Valley was needed to match to the measured heads in the northeast part of the model domain and spring flows at Ash Meadows.

\section{Definition of Extent of Recharge Areas}

The initial distribution of recharge areas was changed during model calibration to determine the sensitivity to their extent and magnitude. Initially, a single multiplication array was used to describe the rate of recharge, and a single multiplication parameter defined to adjust this rate. Thus, the four recharge parameters of table 15 were combined. Composite scaled sensitivities calculated for the initial model indicated that model results were very sensitive to this single recharge parameter (fig. 43). The observation data, therefore, provided substantial information about the single recharge parameter, given the existing model configuration. The large CSS values suggested that use of a single recharge parameter was an oversimplification, and that parameters in multiple recharge areas probably could be estimated with the available data.

A detailed evaluation that had been conducted to delineate various zones of recharge potential was used to divide the single recharge parameter into four zones (fig. 42). Each was assigned a parameter that represented a percent of average annual precipitation that infiltrates. In the final model, $\mathrm{RCH} 0$ and $\mathrm{RCH} 1$ were assigned values of 0 and 1 percent; $\mathrm{RCH} 2$ and $\mathrm{RCH} 3$ were estimated by regression and were variable, ranging from 1 to 10 percent and 10 to 30 percent, respectively.

\section{Variations in Interpretation of Hydrogeologic Framework}

Four types of hydrogeologic framework variations were considered during calibration of the DVRFS model. These include: (1) adjustment of K-zones to improve numerical stability, (2) addition or refinement of K-zones to better define hydrogeologic units or geologic structures included in the 3D hydrogeologic framework model, (3) addition of $\mathrm{K}$-zones to better represent interpreted geologic structures that were not included in the hydrogeologic framework model, (4) addition of new K-zones required to better represent faulted terrains supplying ground water to springs and discharge areas.

The first major change to the $\mathrm{K}$-zone arrays used in this model involved adding a one-cell wide buffer where low (K4) K-zones abutted moderate (K2) and large (K1) K-zones. This buffer, which is most apparent in layer 1 (fig. 44), made the hydraulicconductivity contrast between K-zones more gradual, thus removing a major source of numerical instability in the conjugate gradient solver and greatly improving model run times. In general, the effect on the simulated heads was minimal, though further adjustments were needed to correctly represent spring flow that occurs in these high contrast areas. 

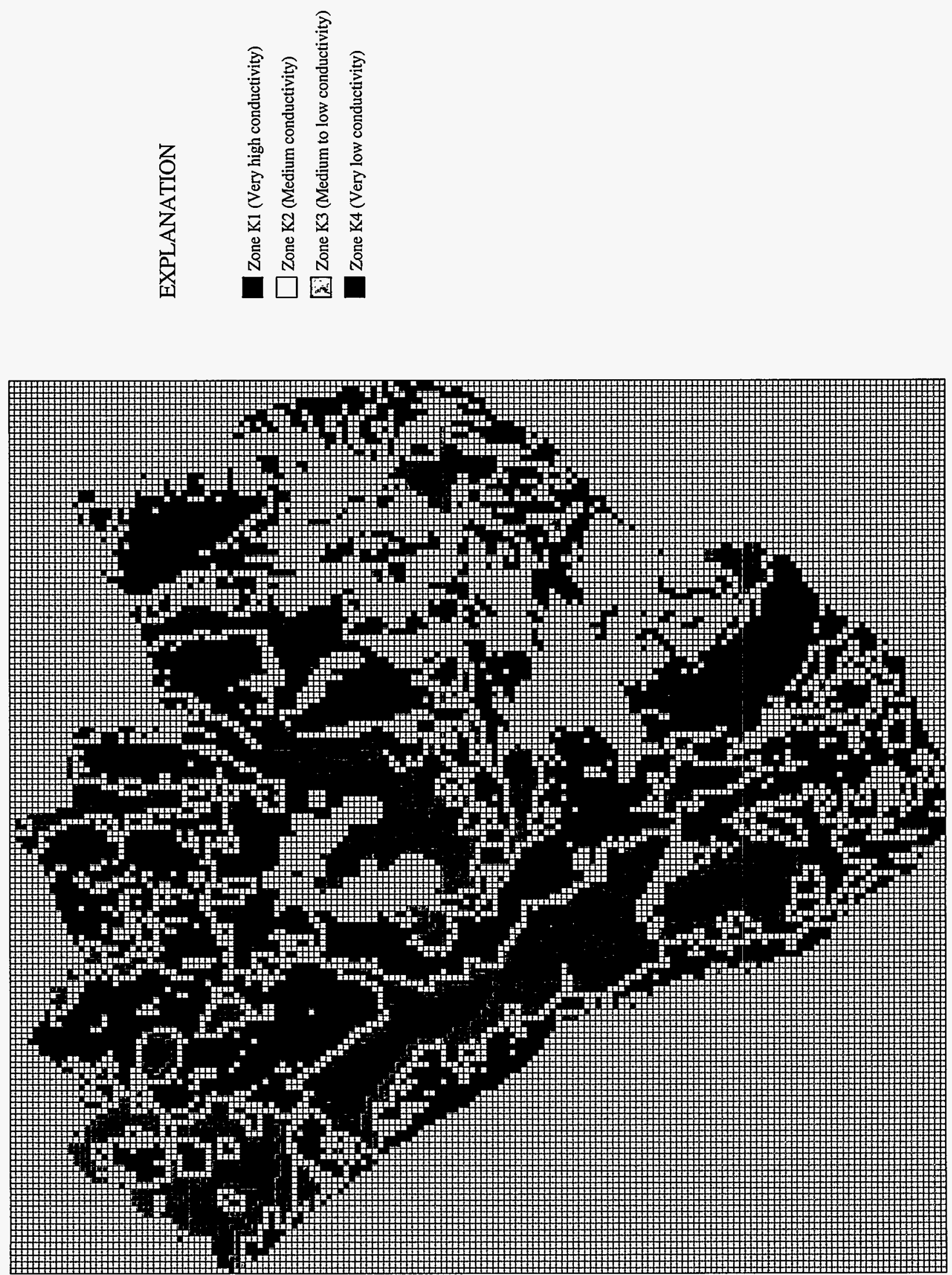

0.

Hydrogeologic Evaluation and Numerical Simulation of the Death Valley Regional Ground-Water Flow System, Nevada and California 
The $\mathrm{K}$-zones also needed to be adjusted because the summation, or averaging, methods removed or obscured some important features that had been included in the 3D hydrogeologic framework model. This was particularly evident at three locations within the model domain: (1) where the PrecambrianPaleozoic clastic, igneous and metamorphic rocks occur in the Amargosa Range (Funeral Mountains), (2) where the Precambrian-Paleozoic clastic rocks occur in the Spring Mountains, and (3) where the low $\mathrm{K}$ Eleana Formation (and adjacent clastic rocks) occurs within the generally higher $\mathrm{K}$ Paleozoic carbonate rocks unit. The location of these units is significant because their distinctive hydraulicconductivity values control important large hydraulicgradient features throughout the area. Composite scaled sensitivity values for the low $K$ parameters $(\mathrm{K} 3$ and $\mathrm{K} 4$ ) in these areas indicate that additional parameters could be estimated (fig. 45). As a result, these zones were subdivided after a careful re-evaluation of the hydrogeologic framework model.

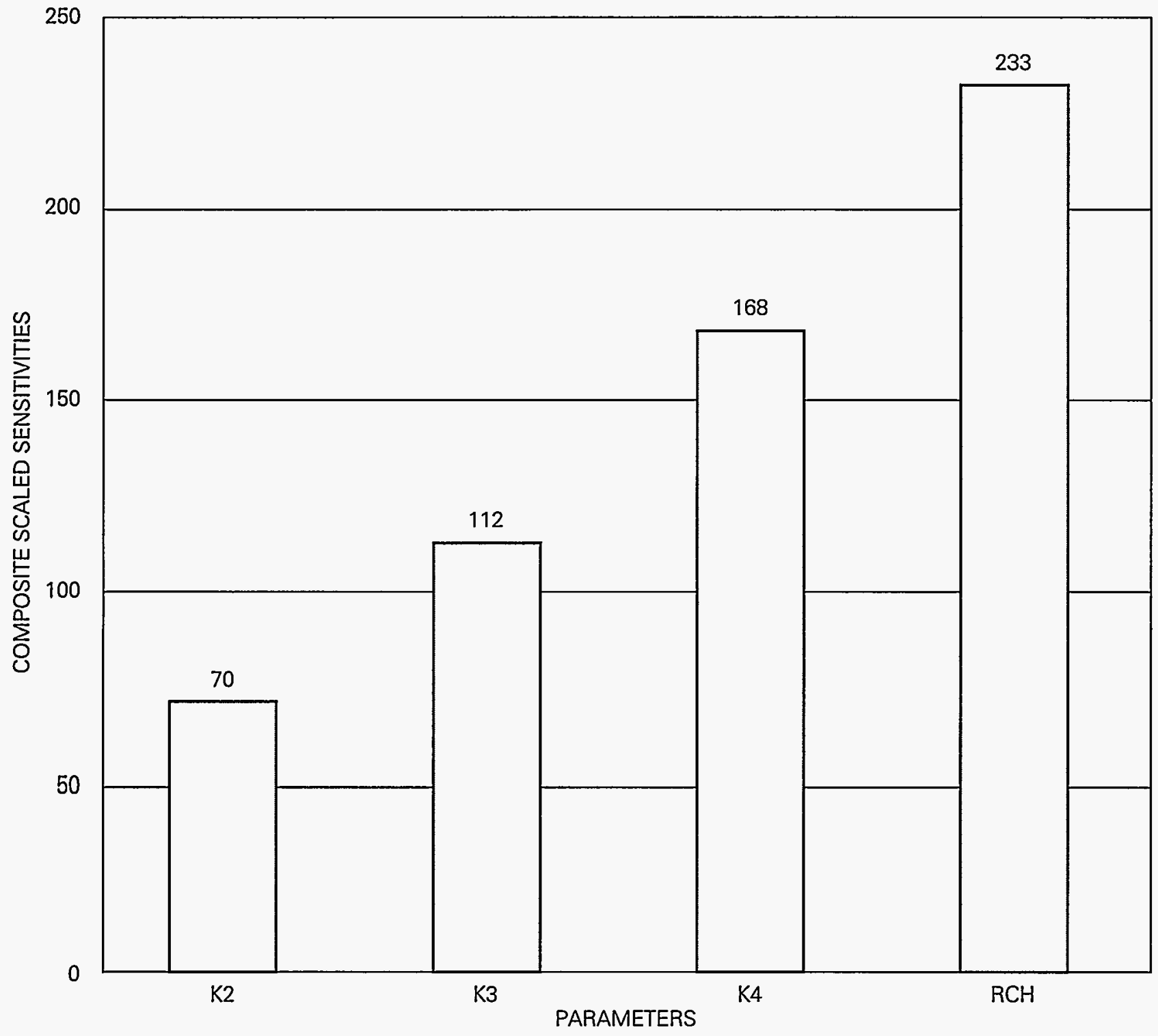

Figure 45. Composite scaled sensitivities of initial model showing relative high sensitivity of parameters K3 and K4. 
The Precambrian-Paleozoic clastic, igneous, and metamorphic rocks in the Amargosa Range control the large hydraulic gradient on the east and northeast side of Death Valley. Hydraulic heads in the southwestern part of the Amargosa Valley also are sensitive to the distribution and hydraulic conductivity of these units in the Funeral Mountains based on MODFLOWP calculated sensitivities.

The location and hydraulic conductivity of the Precambrian-Paleozoic clastic rocks located in the northwestern part of the Spring Mountains appears to affect the accurate simulation of hydraulic heads and spring flows in Indian Springs, Amargosa, and Pahrump valleys. These units appear to be more fractured than those in the Amargosa Range, and in addition, are not associated with Precambrian metamorphic units. They were, therefore, were reassigned from the $\mathrm{K} 4$ to the $\mathrm{K} 3$ zone.

A new $\mathrm{K}$-zone was added in the mountainous area west of Yucca Flat to define the extent of low $\mathrm{K}$ rock units which include the Eleana Formation, Paleozoic quartzites, and dense shaley limestone units. The Eleana Formation is a shale-bearing unit that is stratigraphically a part of the Paleozoic carbonate rocks unit but is generally characterized by lower hydraulic conductivity (Winograd and Thordarson, 1975). Originally the Eleana unit was included with the carbonate rocks in zone $\mathrm{K} 2$, but during calibration a new $\mathrm{K}$-zone (K6) was added to layers 2 and 3 (figs. 46 and 47). The new $\mathrm{K}$-zone includes many of the deep, low $\mathrm{K}$ rocks in this area. Because very little is known about these rocks at depth, the inclusion of these rocks into the new zone is mostly supported by improved model fit. The hydraulic-conductivity value for this $\mathrm{K}$-zone was initially estimated to be approximately $1 \times 10^{-6} \mathrm{~m} /$ day, which is four orders of magnitude smaller than the $\mathrm{K} 2$ value. A better match of heads and flows following this modification supported this change.

Several new $\mathrm{K}$-zones were added to the zone arrays to represent discrete linear fault or fracture zones affecting regional ground-water flow that had not been included in the hydrogeologic framework model. Four specific types of fault features were added to the arrays and tested to determine if they improve the numerical model: (1) NE/SW trending structural zones interpreted by Winograd and Pearson (1976), Carr (1984) and Faunt (1994) as being zones of potentially higher hydraulic conductivity, (2) NW/SE trending faults interpreted by Winograd and Thordarson (1975), Carr (1984) and Faunt (1994) as being zones of potentially lower hydraulic conductivity, and (3) anomalously linear surface-water drainages that have been interpreted by Waddell (1982) and Faunt (1994) as being zones of increased or decreased hydraulic conductivity.

Northeast-southwest trending structural zones were added to the $\mathrm{K}$-zone arrays in four locations in layers 2 and 3 . These features, specified as K5, were added to the lower two layers because they have no surface expression and are, therefore, interpreted as being buried. The first three coincide with the structural zones (fig. 7; a, b, and c) located in the northwest part of the model domain. The fourth $\mathrm{NE} / \mathrm{SW}$ trending structural zone added to layers 2 and 3 (figs. 46 and 47) is coincident with the Spotted Range-Mine Mountain structural zone and Pahranagat shear zone described by Carr (1984) and Faunt (1994) and the megascale channel of high hydraulic conductivity described by Winograd and Pearson (1976). The exact location of these structural zones was not known because expressions of faults are buried by alluvial material. As a result, the features were specified as continuous K-zones by approximating the extent of the feature in the areas where it is buried. Calculated sensitivities may indicate that inclusion of $\mathrm{K} 5$ where it is coincident with the minor NE-SW trending structural zones described by Carr (1984; fig. 7, a, b, and $\mathrm{c}$ ) is most important to simulated hydraulic heads in the northwest part of the model domain and flows to Sand, Grapevine, and Oasis Valley springs. Further, calculated sensitivities may indicate that inclusion of $\mathrm{K} 5$ where it is associated with the Spotted RangeMine Mountain structural zone is most important to hydraulic heads in Yucca Flat and Frenchman Flat and spring flows at Ash Meadows.

Northwest-southeast trending low hydraulicconductivity faults were represented as zone $\mathrm{K} 7 \mathrm{in}$ layers 2 and 3 of the K-zone arrays (figs. 46 and 47). These linear zones are associated with two very large faults, the Death Valley Fault and the Las Vegas Valley shear zone, which have been interpreted as consisting of low permeability fault gouge by Winograd and Thordarson (1975) and Carr (1984). These NW/SE trending features are oriented parallel to the extensional stress field, making them more likely to be relatively closed or have relatively low permeability (Carr, 1984; Faunt, in press). Other interpreted NW/SE trending faults include one that extends from the west side of Pahrump Valley to Ash Meadows, and 


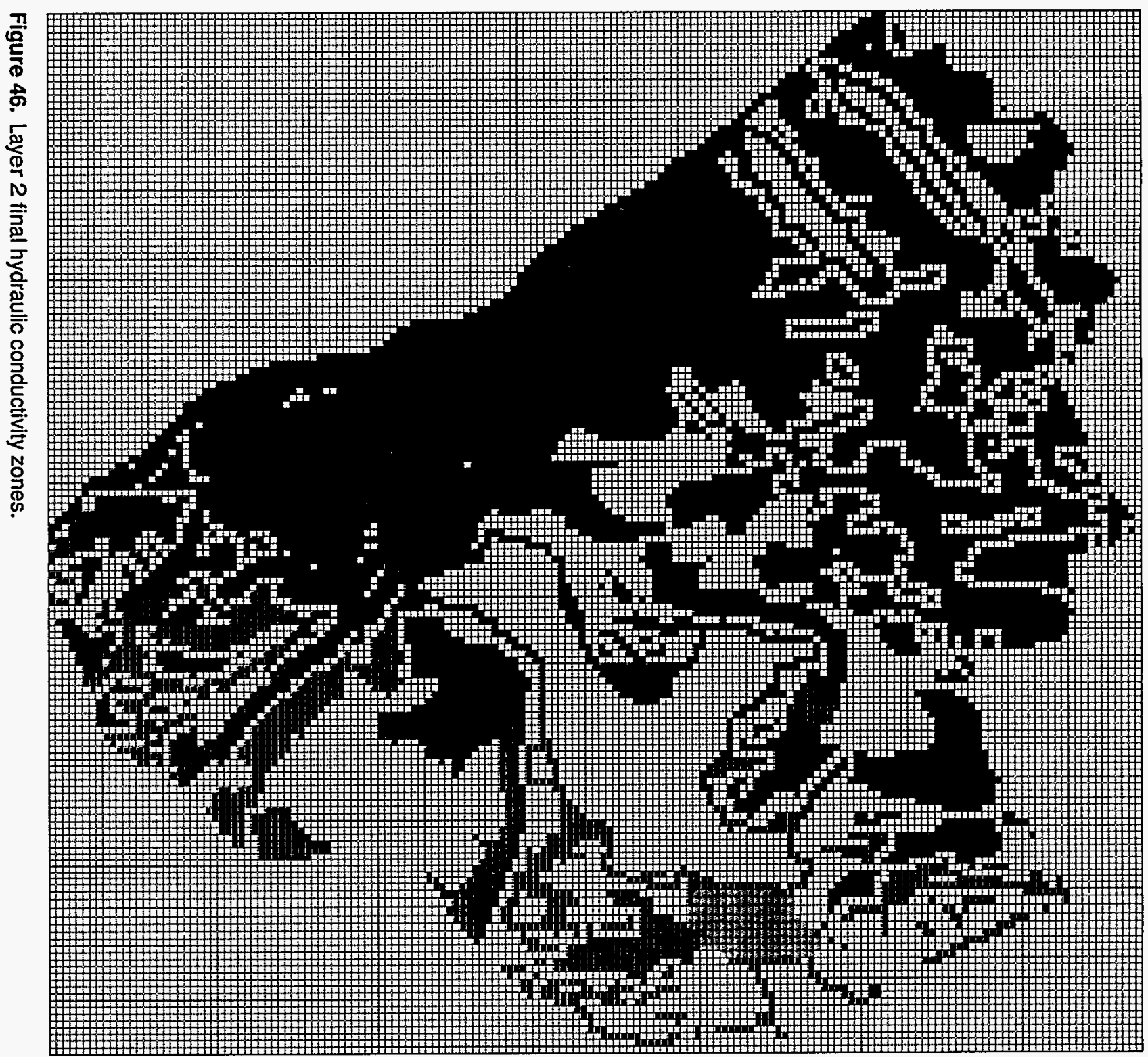

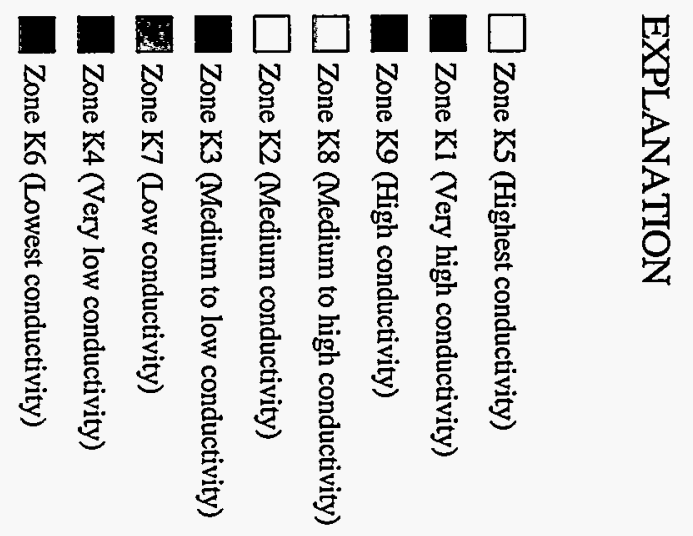



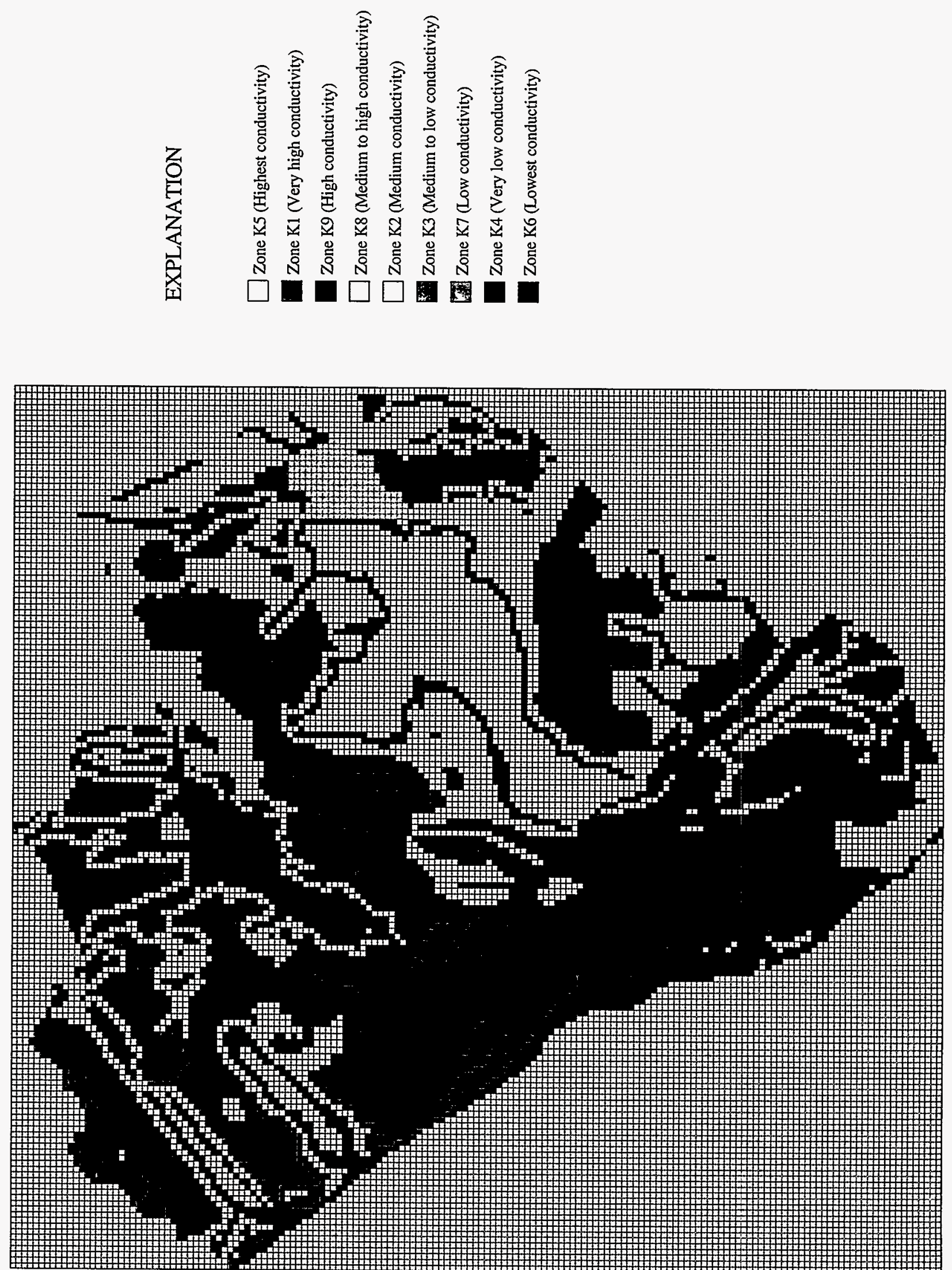

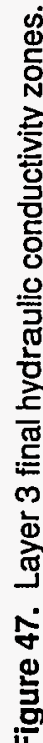

Hydrogeologic Evaluation and Numerical Simulation of the Death Valley Regional Ground-Water Flow System, Nevada and California 
two that extend through the Shoshone/Tecopa area. Adding $\mathrm{K} 7$ to these areas improved flow from regional spring discharge areas at Ash Meadows, Furnace Creek Ranch, and Shoshone/Tecopa. The low hydraulic conductivity, Las Vegas Valley shear zone had the effect of improving hydraulic heads in the Indian Springs and Spring Mountains area. Parameter estimation runs typically resulted in small hydraulic conductivity values of $10^{-4} \mathrm{~m} /$ day for these (K7) features. The CSS value for this parameter when estimated was very small $(0.001)$ as compared with more sensitive parameters with CSS values of 8.0 or 9.0. This small sensitivity may indicate that the model is not sensitive to the exact value of this (K7) parameter as long as the hydraulic-conductivity values are very small. A local decrease of calculated head residuals of $50 \mathrm{~m}$ resulting from the specification of these cells as a separate low $\mathrm{K}$ parameter, however, may indicate that this is an important feature.

Several surface-water drainages in the Death Valley region have been interpreted as resulting from buried structural features. The most significant structural feature of this kind within the model domain is Fortymile Wash which has been interpreted as a structural zone of increased hydraulic conductivity (Waddell, 1982, p.19). A series of cells corresponding to the location of this buried feature were specified as part of K5 (fig. 47). Despite its limited extent, this feature significantly improved hydraulic heads calculated for the lower two layers at Yucca Mountain reducing local hydraulic head residuals by $20 \mathrm{~m}$.

Two very localized additional $\mathrm{K}$-zones were added to parts of the model domain to account for intensely faulted terrains of unknown hydraulic conductivity. These $\mathrm{K}$-zones include areas that describe the hydraulic conductivity of the central Desert Range and the southern Funeral Mountains. K8 represents the hydraulic conductivity of the central Desert Range in layers 2 and 3 (fig. 46 and 47). The simulated flux associated with constant heads at Pahranagat Lakes and associated springs are sensitive to $\mathrm{K} 8$. The rationale for specifying this area as a separate parameter is related to the unknown hydraulic conductivity associated with the fractured quartzite rocks in this region. When this area is specified as part of the Spotted Range-Mine Mountain, high $\mathrm{K}$ zone, the amount of ground-water entering the system is greater than is physically reasonable. When this region is specified as $\mathrm{K} 8$ with an assigned hydraulic conductivity of $0.065 \mathrm{~m} /$ day which is more comparable to the $\mathrm{K}$ estimated by MODFLOWP for similar rocks in the region, a more appropriate amount of ground water is transferred into the basin. The value was assigned instead of being estimated because the calculated CSS value was relatively small indicating low sensitivity compared to other estimated parameters.

The K-zone specified for the southern end of the Funeral Mountains, designated as $\mathrm{K} 9$, was defined to better estimate the hydraulic conductivity of the rocks in this region in layer 3 (fig. 47) which are known to be more highly fractured carbonate rocks. The estimated value for this parameter, which has a CSS value of 0.917 , is $0.16 \mathrm{~m} /$ day. Hydraulic heads in the Amargosa Valley and spring flow to Furnace Creek Ranch are both sensitive to this model parameter.

\section{Data Review and Reweighting}

Model calibration also involved continual review of the head and flow observation data after each parameter-estimation run. These inspections often resulted in uncovering previously overlooked spurious data. Typical spurious data values included: (1) head observations from clearly or potentially perched or local systems located in, or adjacent to, recharge areas, (2) hydraulic-head data that were clearly recorded incorrectly, (3) spring discharge observations that were representative of local conditions, and (4) incorrect spring orifice altitudes represented by the averaging algorithm of the GIS. In addition, some of the spring flow data appeared to be more accurate than anticipated and this influenced its specified coefficient of variation.

Perched hydraulic-head observation data were located in some areas of the model domain. When observations represented local or perched conditions (based on water levels), they were omitted. In areas where hydraulic-head observations were indicative of potentially perched conditions common to recharge areas and large hydraulic gradient areas, they were reweighted. During calibration, hydraulic-head data for the Yucca Flat area included 13 water levels that are representative of a localized, unconfined water table that is perched on the Eleana Formation (Waddell and others, 1984). These water level measurements are difficult to simulate because of the localized nature of the perched system, so they were removed from the observation data set. Weighting for heads in potentially perched areas were modified; for 
8 of the 500 hydraulic head observations, the standard deviations were increased from $10 \mathrm{~m}$ to 100 or $250 \mathrm{~m}$. Weighting for heads was also modified so that measurements areas of large hydraulic gradients were given larger standard deviations: for 16 of the 500 hydraulic-head observations, the standard deviations were increased from $10 \mathrm{~m}$ to $30 \mathrm{~m}$.

During calibration, some water-level measurements were identified as being clearly incorrect. For example, a water-level measurement in the Specter Range area was over $1,000 \mathrm{~m}$ different than water levels located near this observation.

Also, several springs appear to be discharging from regional flow paths; however, very little information is known about these springs that would verify their regional nature. The springs include Sand, Navel and Keane Wonder Springs in Death Valley and Cactus and Indian Springs in the Indian Springs Valley. Because these springs have relatively small discharge volumes (ranging from $20-4,100 \mathrm{~m}^{3} / \mathrm{d}$; all totaling about $4,500 \mathrm{~m}^{3} / \mathrm{d}$ ) compared to many of the other springs that are clearly regionally supported, the coefficient of variation for these estimated spring discharge rates was set to large values of 33 to 100 percent.

Spring altitudes also were reevaluated. During model calibration, several springs were calculated as having either no flows or inflows. Inspection of the spring input data identified incorrect spring altitudes resulting from the averaging of altitudes from the GIS data base. As a result, several spring orifices were specified at altitudes that were too high. For these springs, the altitudes were corrected by locating the spring on large-scale (1:24,000-scale) topographic map sheets.

As a result of data re-evaluation, some spring discharge observations appeared to be more accurate than previously expected. The coefficients of variation for some of these flows with very complete records were decreased from 10 to 5 percent; for spring flows that were not well defined or were fieldestimated coefficients of variation were increased from 10 to 100 percent.

\section{Model Fit}

As discussed, a long list of additional features was added to the DVRFS model during the calibration process. Inclusion of each feature improved model fit, so it was retained. It was expected that several models might be considered in the final analysis. The results of the present calibration, however, clearly indicate one model produced a better fit to observed heads and flows than the others.

To obtain a clearer understanding of model strengths and inadequacies, the model was examined to determine how closely observed hydraulic heads were matched in areas of fiat and large hydraulic gradients, how well large hydraulic gradients were reproduced, and how closely observed spring discharges were matched.

In areas of flatter hydraulic gradients, simulated hydraulic heads are within $75 \mathrm{~m}$ of observed values everywhere in the model and are generally within $50 \mathrm{~m}$. In areas of steep hydraulic gradients, the differences between simulated and observed heads are sometimes larger (as large as $300 \mathrm{~m}$ ), but all simulated gradients are within 60 percent of the gradients calculated from the observed hydraulic-head data. The match is good considering the $2,000 \mathrm{~m}$ head drop across the system.

Matching spring flows was difficult but provided important information to the calibration. Indeed, it would not have been possible to support the complex representation of the system produced through the calibration without the spring flow data. The sum of all simulated spring flows is $51,700 \mathrm{~m}^{3} / \mathrm{d}$; the sum of observed spring flows is $120,000 \mathrm{~m}^{3} / \mathrm{d}$. The difference may result, in part, because the observed values for spring flow probably include seepage that is not strictly discharging from the spring orifice and is partially diffuse flow. In addition, determining spring orifice altitudes from topographic maps of mountainous terrain may result in generally high values, which reduce simulated flows.

When weighted as described above, $\mathrm{S}(\underline{\mathrm{b}})$ for heads equals 9,500 ; for flows it is 1,650 , and the total is 11,150 . The standard error of the regression equals 4.5 which indicates that overall model fit is consistent with head standard deviations that are 4.5 times the assigned values: thus, effective model fit for most wells is $45 \mathrm{~m}$. For flow, overall model fit is consistent with 4.6 times the assigned coefficients of variation of 5 to 100 percent. Thus, effective model fit is between 23 and 460 percent. 


\section{MODEL EVALUATION}

After calibration, the DVRFS model was evaluated to assess the likely accuracy of simulated results. This is accomplished by comparing measured and expected quantities with simulated values. The quantities included in the comparisons are (1) hydraulic heads and spring flows, which were matched by the regression; (2) hydraulic conductivities, vertical anisotropy, and percent of precipitation that infiltrates, all of which were represented by parameters estimated in the regression; and (3) water budgets.

An advantage of calibrating the DVRFS model using nonlinear regression is the existence of substantial methodology by which to evaluate model results. As will be demonstrated, these methods produce a more thorough evaluation than is normally accomplished and reported when calibrating using trial-and-error methods. The thorough analysis provided produces a good understanding of the strengths and weaknesses of the model, and the likely accuracy of simulated results and associated confidence intervals and other measures of parameter and prediction uncertainty. Such information was not available for previous models of the Death Valley region.

\section{Hydraulic Heads and Spring Flows}

The values matched by the regression (the elements of vector $y$ of eq. 1) initially included 512 measured hydraulic heads and 63 measured flows. During calibration, 12 hydraulic-head observations were removed from the data set because of obvious errors, thus 500 head observations were matched in the final regression. Five of these remaining hydraulic head observations are questionable; they appear to represent local perched water levels rather than regional water levels. These five observations were retained in the regression data set, however, because their true status could not be determined.

Matching each of the 63 individual measured spring flows during calibration was very difficult. Matching these individual flows is also of questionable value because many springs are located in adjacent grid cells. A more appropriate approach to matching flows, used for this calibration, was to group the 63 springs into 16 groups based on proximity and likely depth from which the springs originate. The 16 total flows were then, with the hydraulic heads discussed above, used as observations in the regression.

Unweighted and weighted residuals for the DVRFS model (figs. 48-55) are important indicators of model fit and, depending somewhat on data quality, model accuracy. Consideration of unweighted residuals is intuitively appealing because the values equal the difference between measured and simulated values. Thus, unweighted residuals are used to communicate how much, for example, simulated hydraulic heads differ from observed hydraulic heads.

Unweighted residuals can be misleading because not all observations have been measured with the same precision. For the regression, each of the observed head and spring flow values were assigned an estimated standard deviation or coefficient of variation based on how precise the measurement was thought to be. This statistic was used to calculate the weights of equation 1. More precise measurements were assigned a larger weight (smaller standard deviation or coefficient of variation) indicating that a closer fit was important when the measurement was precise; less precise measurements were assigned a smaller weight (larger standard deviation or coefficient of variation) indicating that larger discrepancies between the simulated values and these less precise measured values would be tolerated. Weighted residuals equal the square root of the weight of equation 1 times the residual and, therefore, demonstrate model fit relative to what is expected in the calibration based on the precision, or noise, of the data.

For example, heads measured in areas of flat hydraulic gradients generally are not greatly in error resulting from topographic map location or model discretization errors. Heads located in this area, therefore, were relatively precise and had larger weights. Heads measured in areas of large hydraulic gradients generally possess a greater amount of altitude error and, therefore, were less precise and had smaller weights.

Plotting weighted residuals instead of the unweighted residuals results in an analysis which reflects model fit relative to the expected model fit. Large values indicate observations where the fit is poor relative to the fit that was expected based on knowledge of measurement accuracy. Head and flow unweighted and weighted residuals, therefore, are 


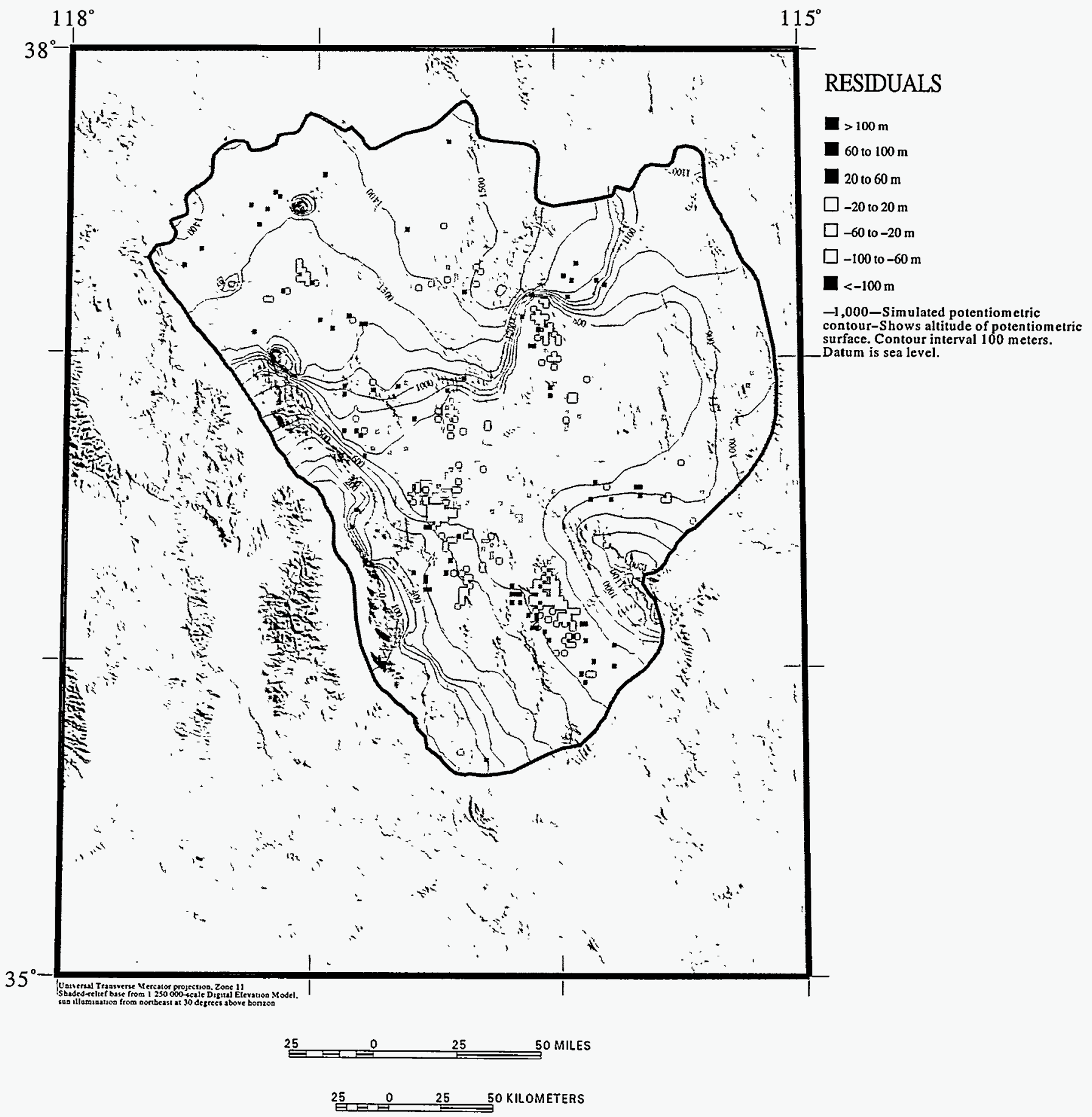

Figure 48. Hydraulic head residuals (observed minus simulated) for model layer 1. 


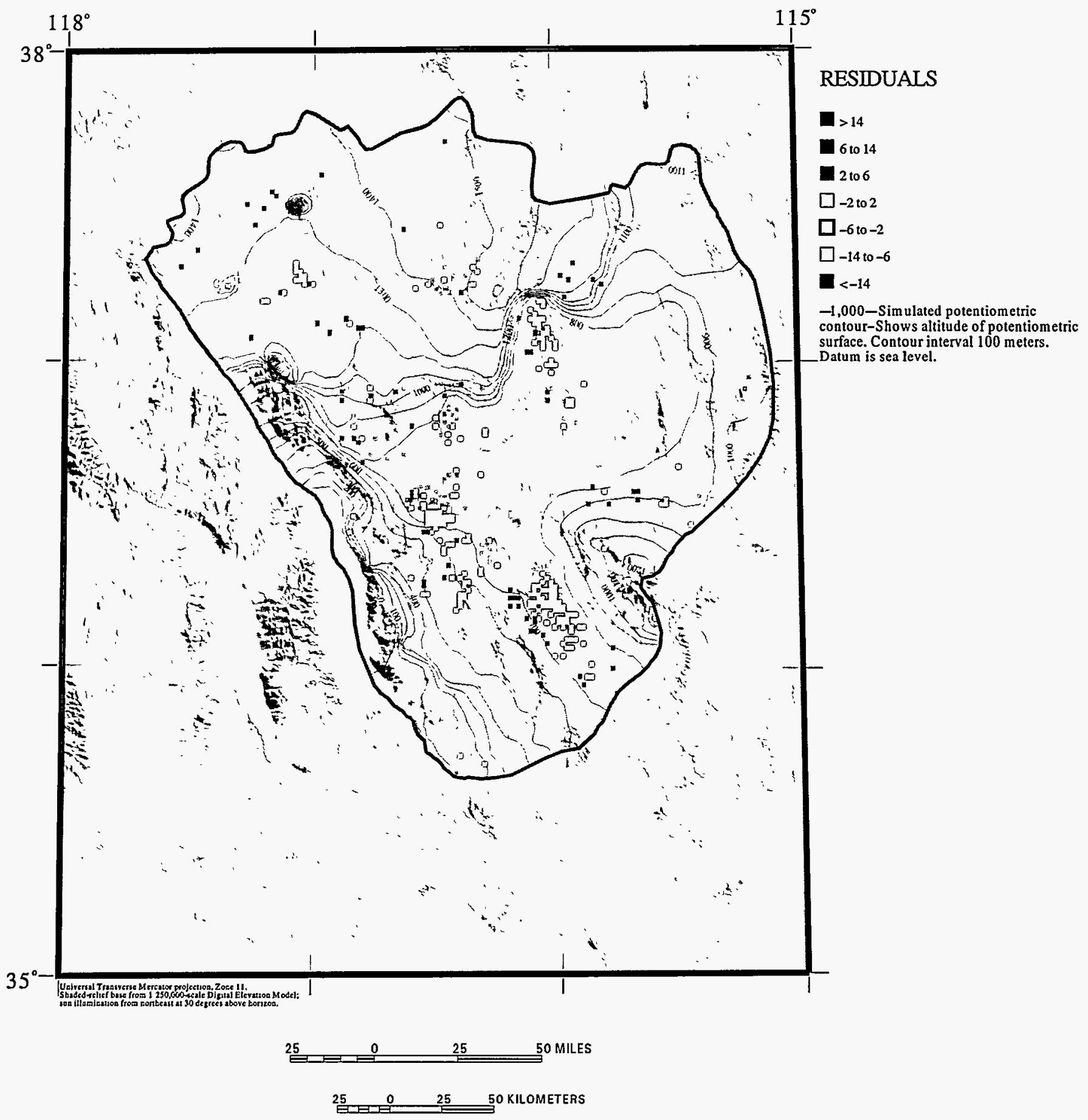

Figure 49. Hydraulic head weighted residuals (observed minus simulated) for model layer 1. 


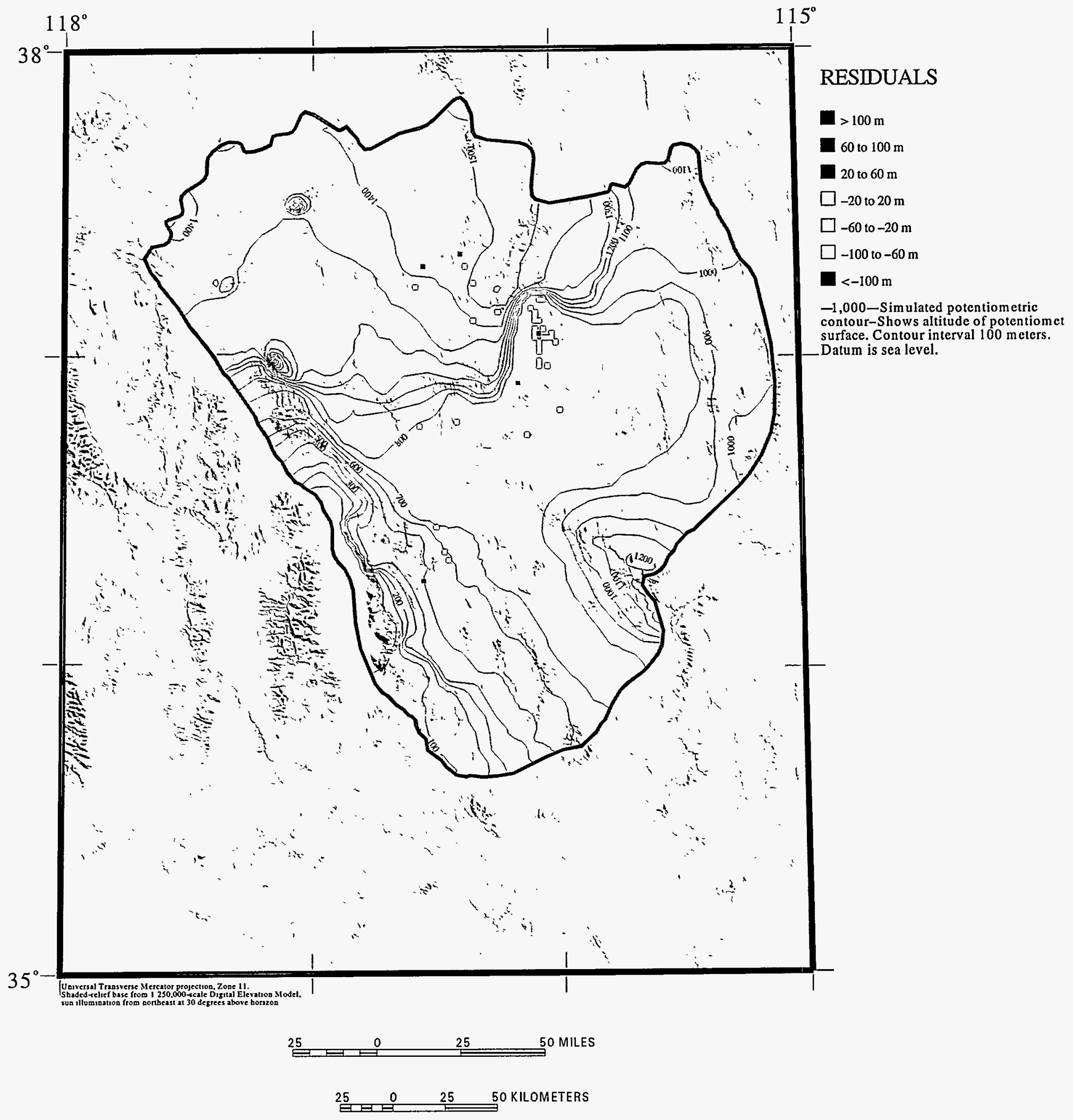

Figure 50. Hydraulic head residuals (observed minus simulated) for model layer 2. 


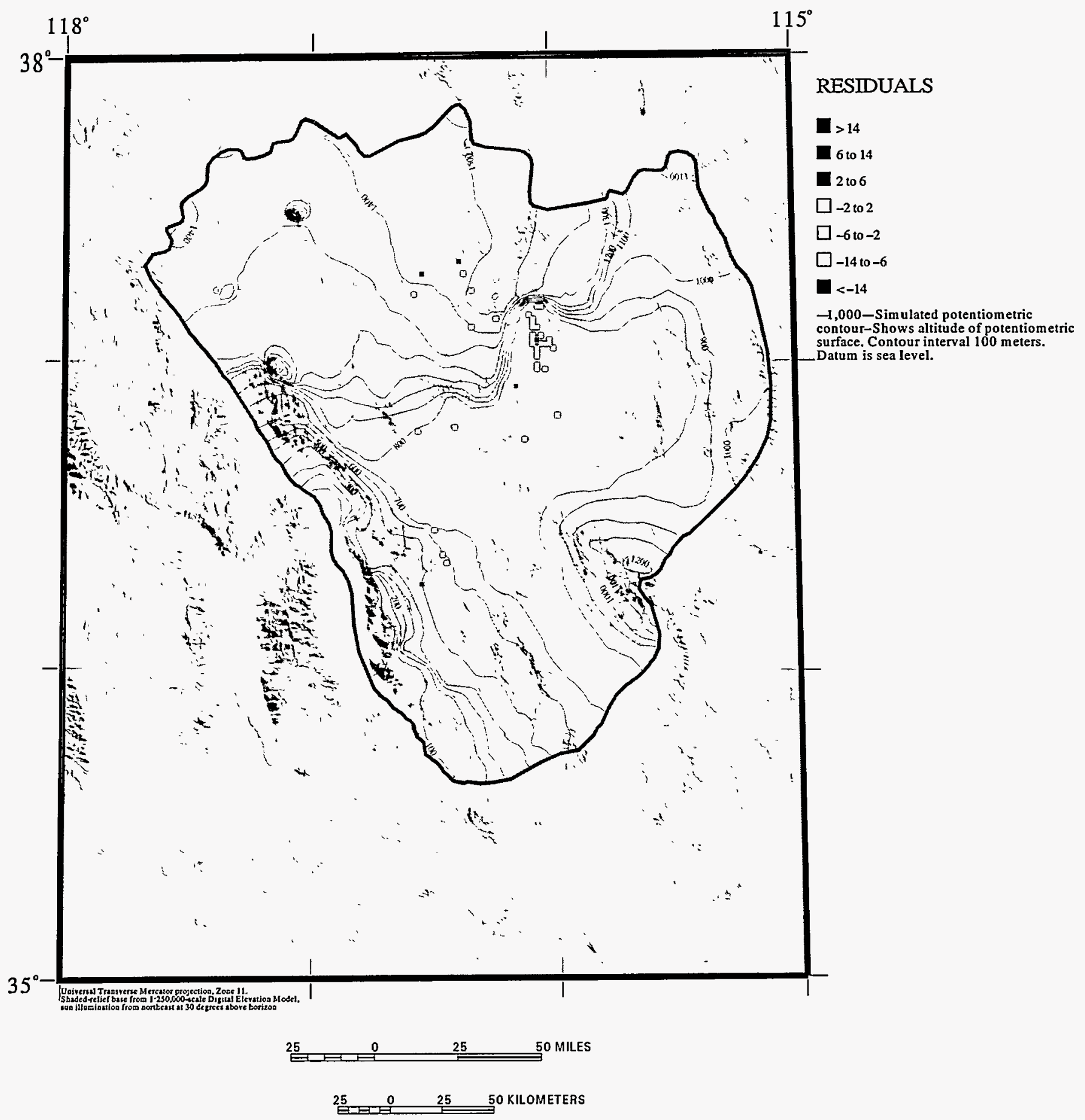

Figure 51. Hydraulic head weighted residuals (observed minus simulated) for model layer 2. 


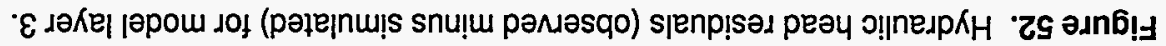

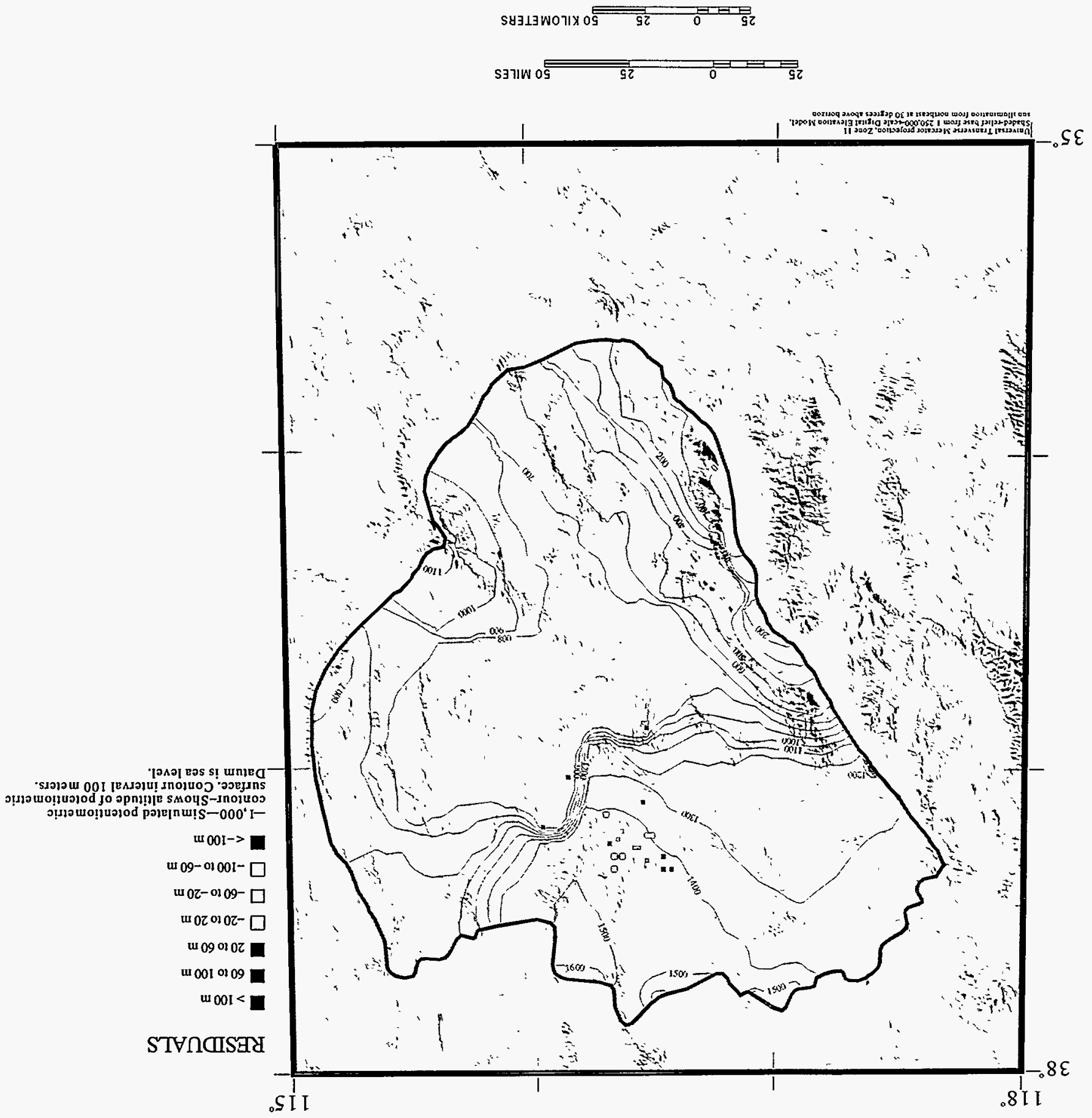




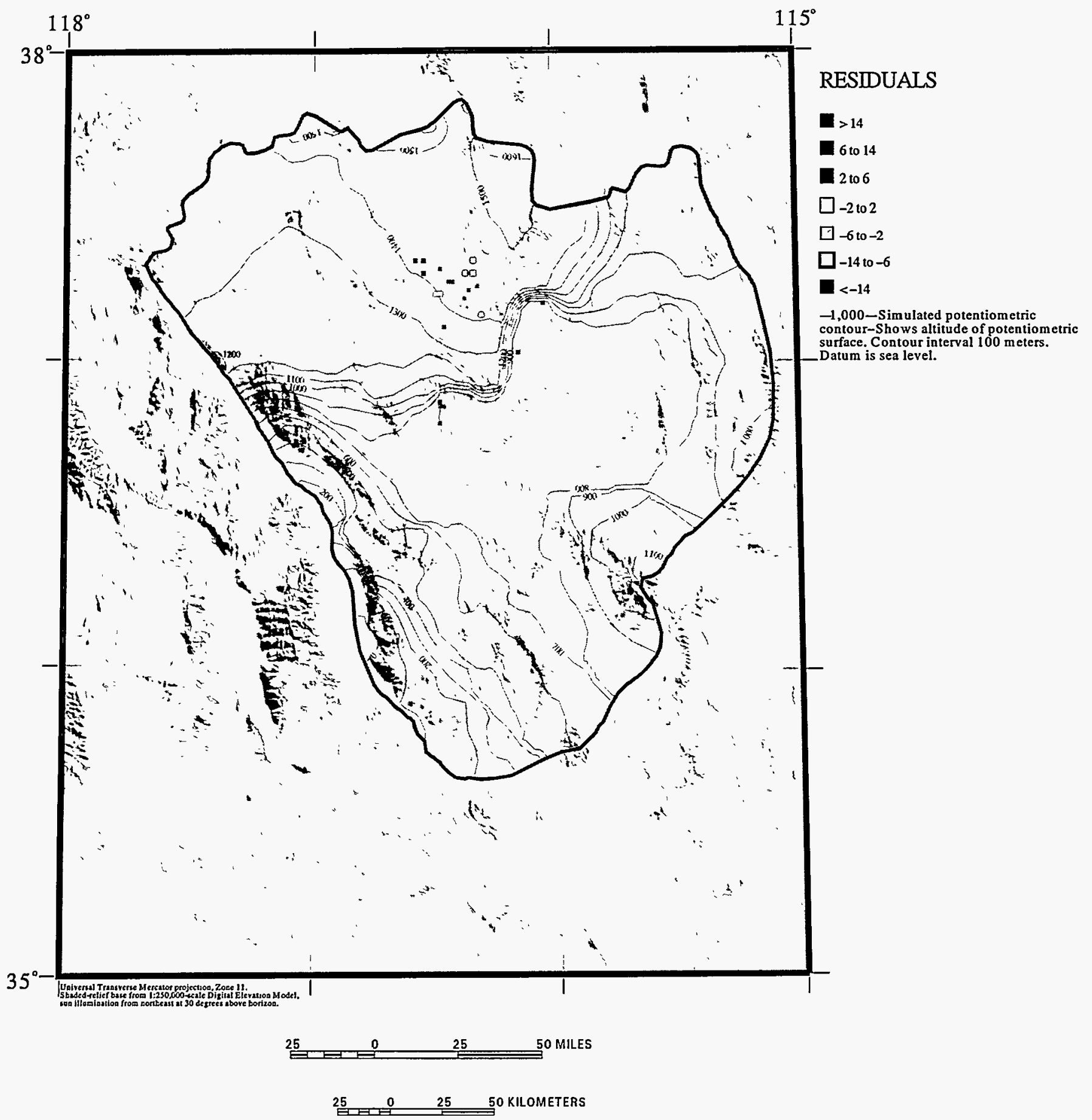

Figure 53. Hydraulic head weighted residuals (observed minus simulated) for model layer 3. 


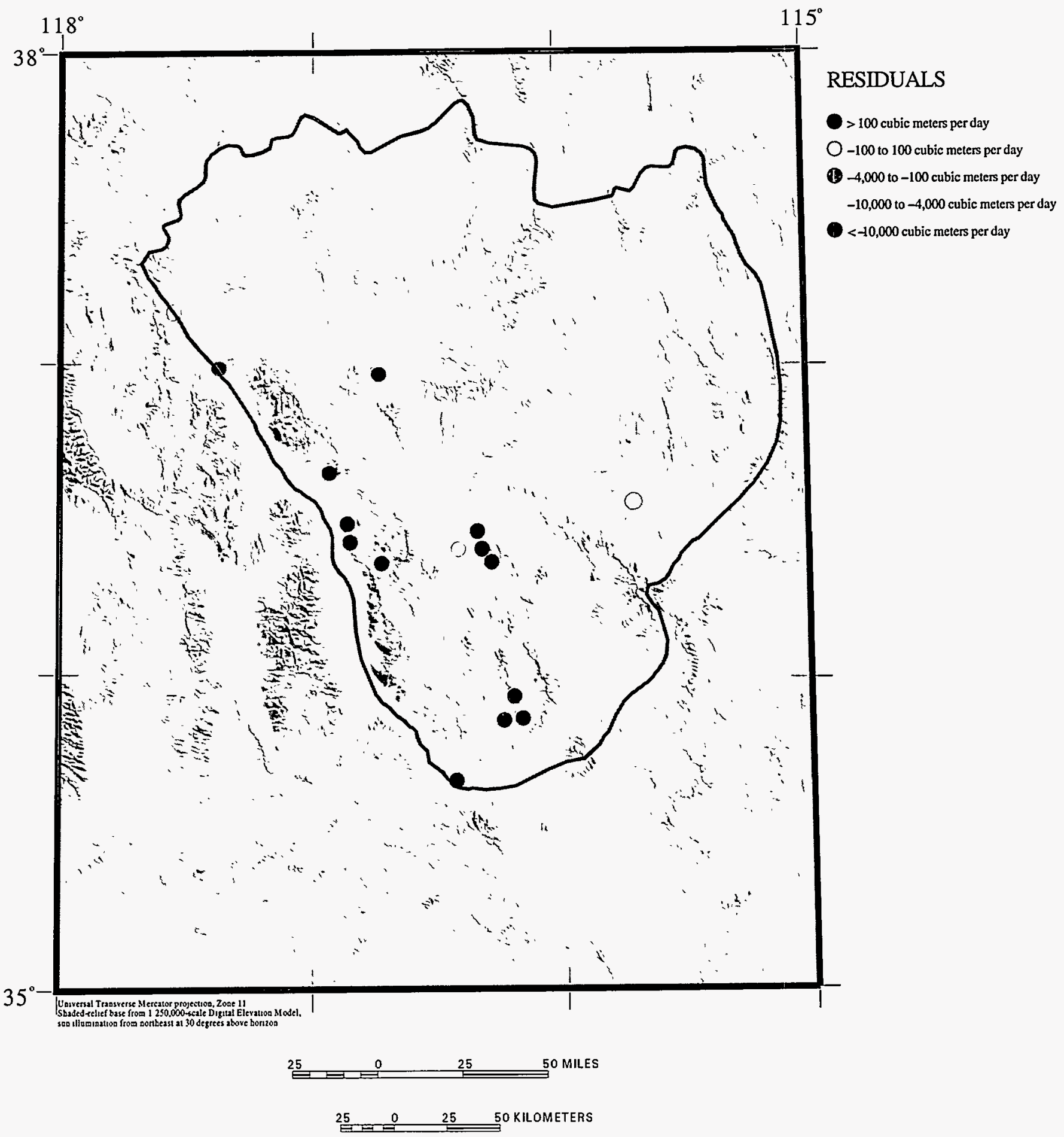

Figure 54. Spring flow residuals. 


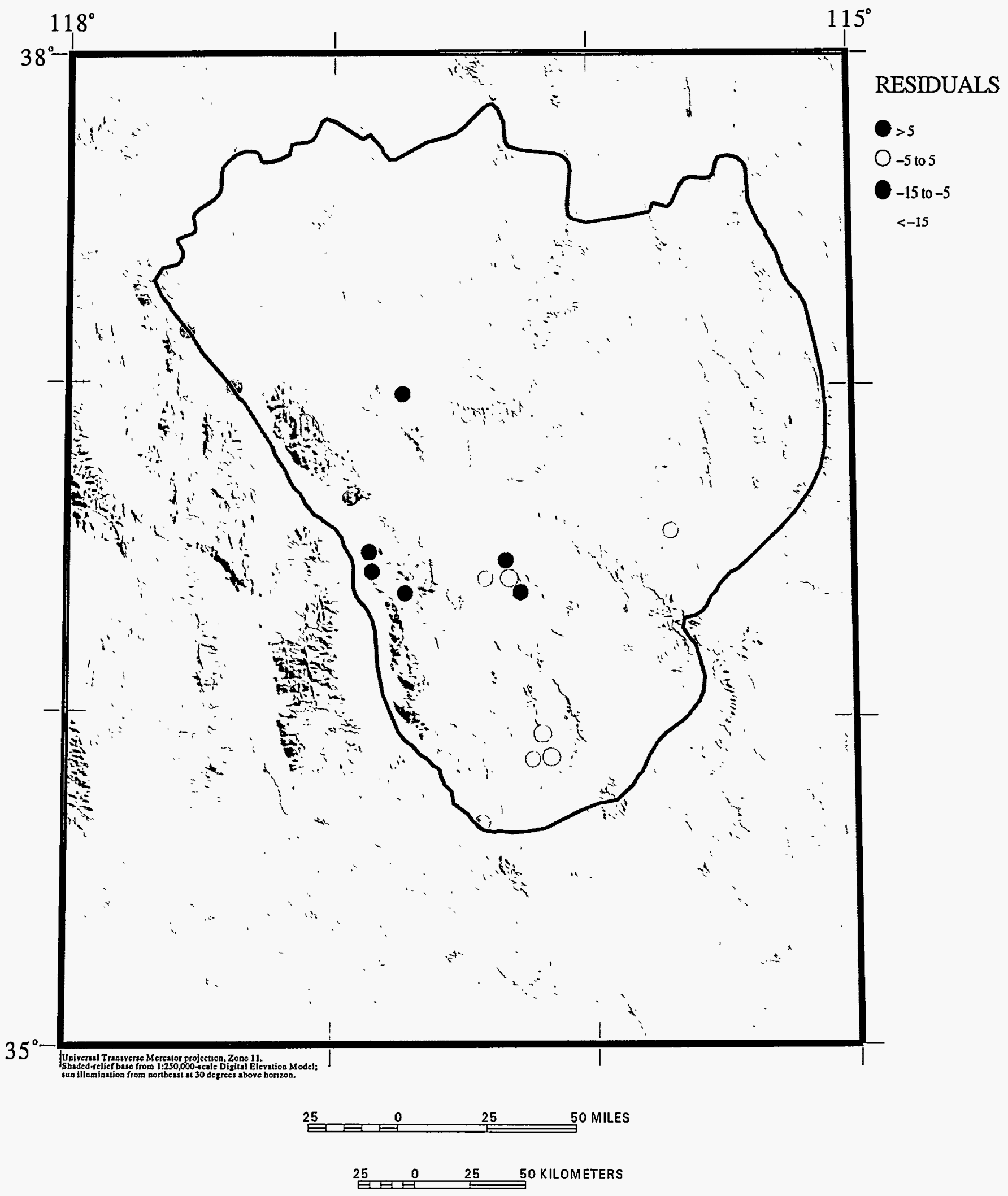

Figure 55. Spring flow weighted residuals. 
evaluated based on their spatial distribution, the distribution of weighted residuals relative to weighted simulated heads and flows, and whether the weighted residuals are normally distributed. An analysis of model linearity, which is important in the interpretation of linear confidence intervals, is also included.

\section{Spatial Distribution of Residuals and Weighted Residuals}

Comparison of simulated hydraulic heads with the potentiometric surface map of figure 27 indicates that the DVRFS model results depict major features of the head distribution very well. Areas of flat and large hydraulic gradients are appropriately located.

Reproduction of large hydraulic gradients ranges from 60 to 110 percent of observed conditions. A more detailed evaluation of the match obtained can be derived by considering maps of residuals.

Unweighted residuals for hydraulic heads and spring flows were initially plotted on maps of the model layers to show their spatial distribution (figs. 48, 50, and 52). Good fit to observed heads (residuals with absolute values less than $20 \mathrm{~m}$ ) generally occurs in areas of fiat hydraulic gradients; moderate fit to observed heads (residuals with absolute values of 20 to $60 \mathrm{~m}$ ) dominates the remainder of the flat hydraulic gradient areas. Poorer fit to observed heads (residuals with absolute values of greater than $60 \mathrm{~m}$ ) appear to occur in large hydraulic gradient areas. Two head observations with residuals with absolute values of greater than $60 \mathrm{~m}$ occur near the west end of Yucca Flat. These are believed to reflect perched ground-water conditions.

Weighted head residuals are plotted on maps of the model layers in figures 49,51 , and 53. Patterns in the spatial distribution of weighted residuals on the maps of unweighted and weighted residuals indicate a nonrandom distribution and suggests that the model may be in error. In layer 1 , simulated heads in the northwest and northeast appear to be lower than observed. Very little observation data, however, exists in these areas, and existing data is of poorer quality than that which is in the remainder of the domain. Along a band extending from the Amargosa Valley southeast to the south end of Pahrump Valley, simulated heads are higher than observed heads to the northeast, and lower than the observed heads towards the southwest. This indicates that although the simulated and observed head gradients are both toward the southwest, the simulated gradient is somewhat steeper that the observed gradient. The remainder of layer 1 appears to bear a random distribution of weighted head residuals. In layer 2 , most residuals are small. The five larger residuals are all positive, but this may not indicate a problem because of their wide areal distribution. In layer 3, a larger proportion of the residuals are large in absolute value than in the other layers. The data in layer 3 are, however, concentrated on Pahute Mesa and adjacent to larger hydraulic gradients, which were difficult to reproduce in all model layers. It is not clear, therefore, if the large head residuals indicate that the deep system is represented less accurately than the shallow system.

It is apparent that most spring flow residuals (fig. 54) are negative, indicating that, for most springs, simulated flows are less than observed flows. The largest unweighted spring flow residuals (fig. 55) occur at the three groups of springs located at Ash Meadows. These groups of springs are also the largest volume springs discharging in the model. The plot of spring flow weighted residuals gives a better representation of how well the model was expected to match the spring flow observation data. This plot shows that the small-volume simulated spring discharge values are well within the range expected for the model. The large-volume spring discharge areas at Oasis Valley, Furnace Creek, Ash Meadows and Tecopa, however, are not discharging at volumes that are expected from the lowest layer (layer 3). This indicates that the simulated contribution from deep flow paths is not as large as it should be. Improvement may possibly be achieved from a more detailed evaluation of the spring conductance (GHB) parameters. Estimation of the more sensitive of these parameters may result in a better model fit.

\section{Distribution of Residuals and Weighted Residuals Relative to Weighted Simulated Values}

Ideally, residuals vary randomly about zero regardless of the simulated value. To obtain statistically not correlated quantities, weighted residuals are plotted against weighted simulated values (Draper and Smith, 1981, p. 147-148; Cooley and Naff, 1990).

Figure 56 shows that the weighted residuals for hydraulic heads generally vary randomly about a value 


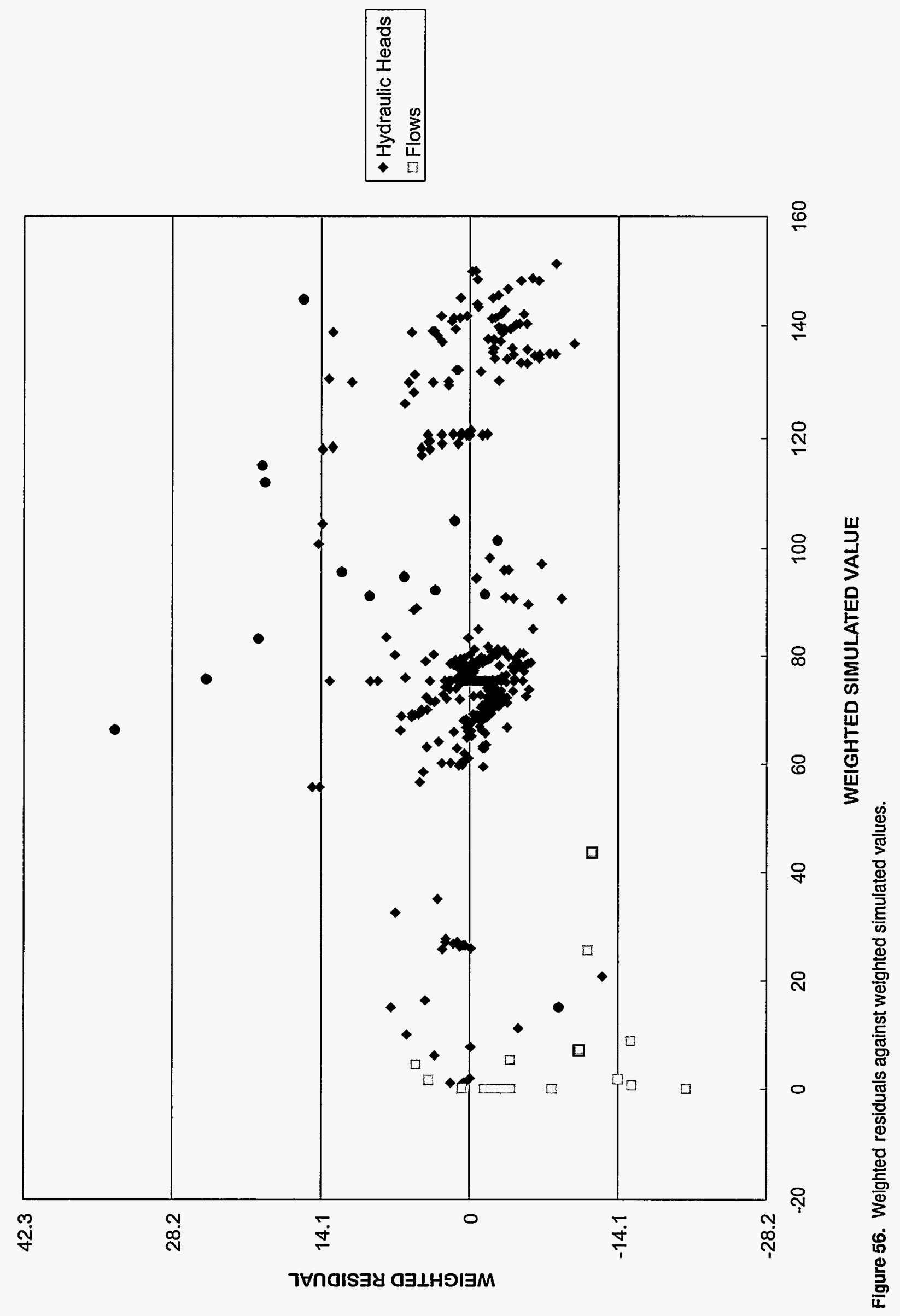


of zero, without regard to the weighted simulated hydraulic head. Weighted residuals with the largest absolute values tend to be positive. Nine values are greater than +14.1 , which is three times the standard error of the regression value of 4.6. No values are less than -14.1. Thus, this distribution is distinctly nonnormal, and probably can not be explained simply by measurement error. Positive residuals indicate that the simulated head is lower than the observed head. The largest of the large positive weighted residuals are for the same hydraulic heads that had large positive values in figure 48 . These observations may reflect perched ground-water conditions and, therefore, demonstrate unusual errors in the data set rather than errors in the DVRFS model.

The weighted residuals for spring flows do not seem to be related to their weighted simulated values. As in figure 55, negative values dominate. For two of the weighted residuals, the absolute values are more than three times the standard error of the regression. Because of the sign convention used, negative weighted residuals for spring flows indicate that the observed flows are larger in magnitude than the simulated flows. Whether or not this is an important model error may be judged in the context of the total flux at the discharge areas, which includes ET. As discussed below, the match to total flux at the discharge areas is good.

\section{Normality of Weighted Residuals and Model Linearity}

The normality of the weighted residuals and model linearity are important to the use of measures of parameter and prediction uncertainty, such as linear confidence intervals. Specifically, the weighted residuals need to be normally distributed and the model needs to be effectively linear for the parameter values to be normally distributed. Normally distributed parameters are important to the calculation of linear confidence intervals on estimated parameters and predicted heads and flows (Seber and Wild, 1989; Hill, 1994; Christensen and Cooley, 1996).

The normal probability plot of the weighted residuals is shown in figure 57; the points would be expected to fall along a straight line if the weighted residuals were both independent and normal. Clearly, the points do not fall along a straight line. One possibility is that the residuals are normally distributed, but they are correlated instead of being indepen- dent. Correlations are derived from the fitting of the regression. This source of correlation can be investigated using the graphical procedures described by Cooley and Naff (1990, p. 168). Normally distributed random numbers generated to be consistent with the regression derived correlations are called correlated normal random deviates, and are shown in figure 58. These plots show that most of the curvilinearity in figure 57 cannot be attributed to regression-derived correlations, but some of the curving related to extreme values might be explained. This analysis indicates that the assumption of normality can not be supported.

Model linearity can be tested using a statistic referred to as the modified Beale's measure (Cooley and Naff, 1990), which is calculated using methods described by Hill (1994). The modified Beale's measure calculated for the DVRFS model equals 0.42 , which is between the critical values of 0.05 and 0.5 . If Beale's measure is less than 0.05 the model is effectively linear. If Beale's measure is greater than 0.5 the model is highly nonlinear. Thus, the final model tends toward being highly nonlinear. The lack of normality of the weighted residuals and the nearly high degree of nonlinearity of the DVRFS model indicate that linear confidence intervals need to be thought of as rough indicators of simulation uncertainty.

\section{Estimated Parameter Values}

The set of parameters estimated by regression in the DVRFS model includes all of the most important system characteristics, as indicated by a sensitivity analysis. This helps to ensure that the measures of prediction uncertainty calculated using the model will reflect most of the uncertainty in the system, because all measures of prediction uncertainty presently available only propagate the uncertainty of the estimated parameter values. Uncertainty in other aspects of the model are not propagated into the uncertainty measures as thoroughly.

If a model represents a physical system adequately, and the data used in the regression (heads and flows for the DVRFS model) provides substantial information about the parameters being estimated, it is reasonable to think that the parameter values that produce the best match between the measured and simulated heads and flows would be realistic values, based on knowledge of rock type and so on. Thus, 


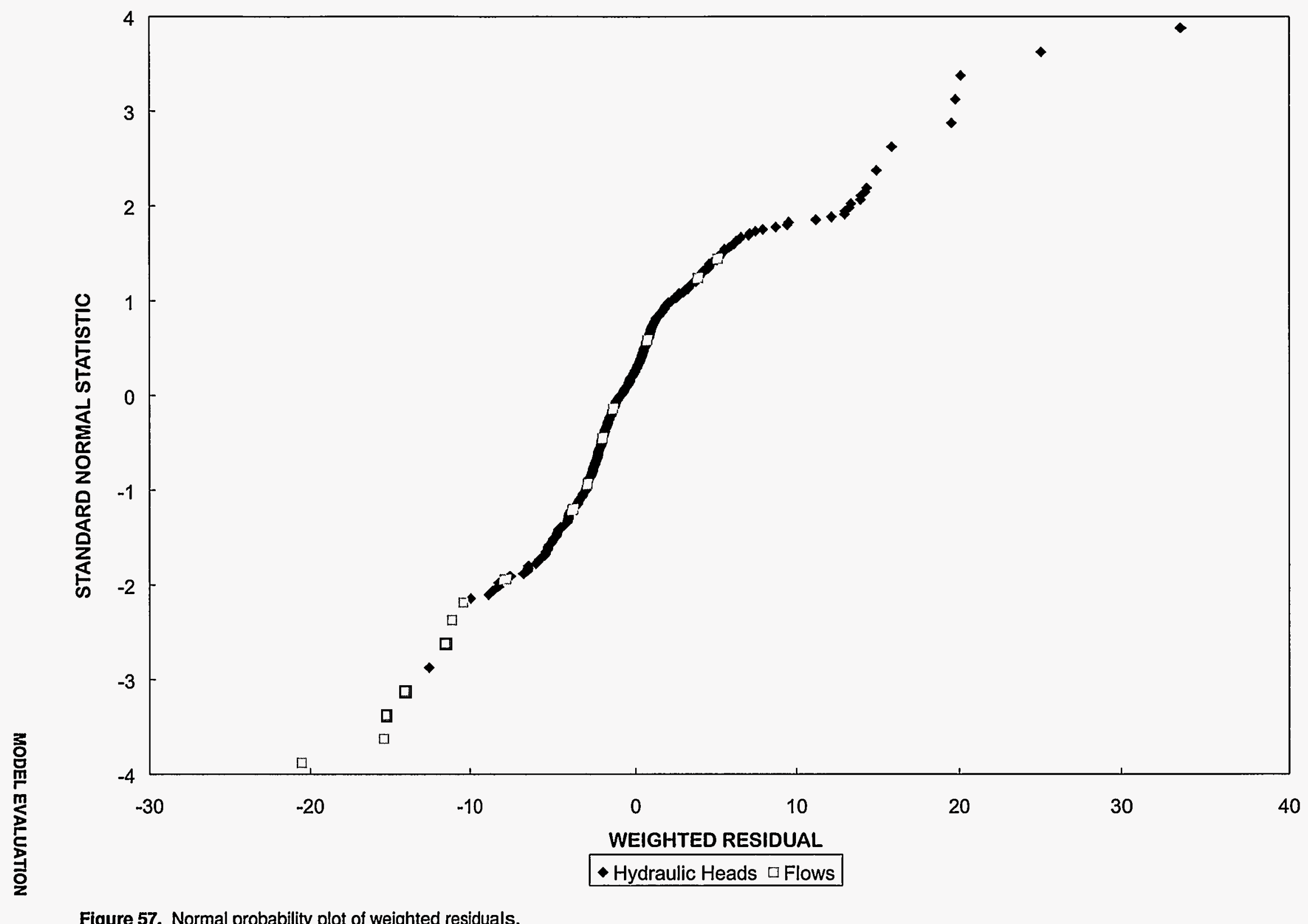

함 


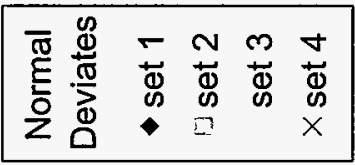

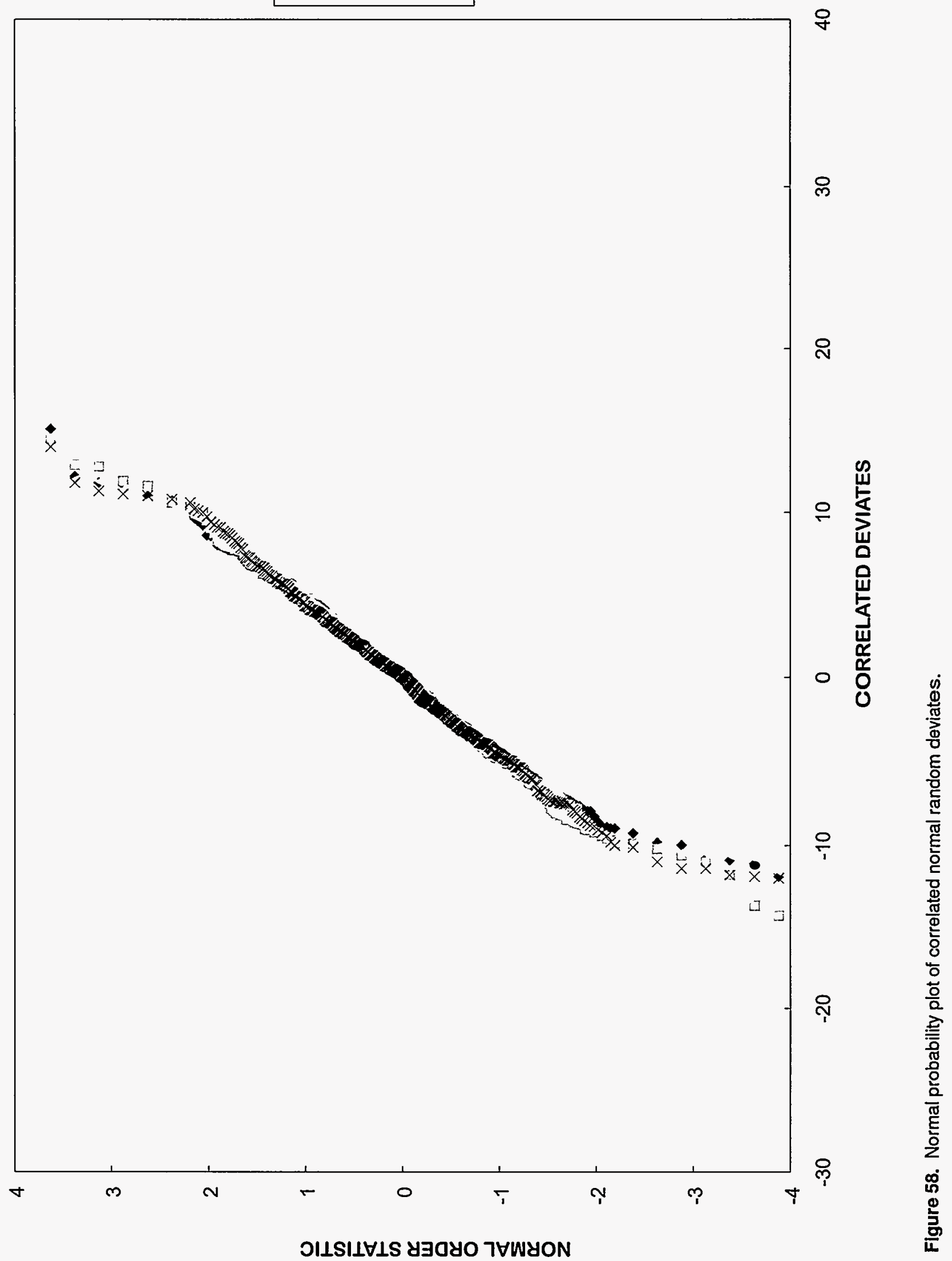


another indication of model error is provided by unreasonable estimates of parameters for which the data provide substantial information (Poeter and Hill, 1996; Hill and others, in review).

A measure of the amount of information provided by the data for any parameter is the composite scaled sensitivity discussed earlier and the linear confidence interval on the parameter, which is calculated using the linearized standard deviation of the parameter provided by the regression. Generally, a parameter with a large composite scaled sensitivity will have a small confidence interval relative to a parameter with a smaller composite scaled sensitivity. The approximate limits of the commonly used linear 95-percent confidence interval are calculated as the estimated parameter value minus two times the standard deviation, and the estimated value plus two times the standard deviation. If an estimated parameter value is unreasonable and the data provide enough information that the linear 95-percent confidence interval on the parameter estimate also excludes reasonable parameter values, the problem may not be lack of data or insensitivity, but is more likely to be model error or misinterpreted data.

Table 16 shows the estimated parameter values and their coefficients of variation (the standard deviation of the estimate divided by the estimated value) and 95-percent linear confidence intervals, and the range of values thought to be reasonable based on information gathered as part of the regional hydrogeologic characterization but not used in the regression. The hydraulic conductivity parameter values together with their confidence intervals and reasonable ranges of values are also shown in figure 59. In all cases, the optimized parameter value is within its expected range, though most of the hydraulic conductivity estimates tend to be in the upper end of the reasonable range. It is hypothesized that this results from regional fractures that contribute to the estimated values of regional hydraulic conductivity.

No prior information was included in the sumof-squares objective function to restrict the estimation process; only the model design and the observation data influenced parameter estimation. Estimation of the most important parameters without prior information strengthens the significance of model results because it allows the hard data, the hydraulic heads and flows, to have the maximum possible influence on the calibrated model. In this approach, the available information on reasonable parameter values can be used to compare the estimated parameter values. For the DVRFS model, this comparison revealed no indication of model error.

Composite scaled sensitivities (CSS) were used during calibration to decide what parameters to maintain and exclude from the estimation process. Partly because of model nonlinearity, the values of CSS change somewhat as the parameter values change (Anderman and others, in press). As a result, the evaluation of CSS values needs to be repeated with the final model. CSS values for estimated parameters in the final model are shown in figure 60. The final CSS values changed somewhat, but were still quite similar to initial values.

Table 16. Estimated values, coefficients of variation, and the 95-percent linear confidence intervals for the parameters of the final calibrated model, and the range of reasonable values, with the range of reasonable values

\begin{tabular}{lccccc}
\hline $\begin{array}{c}\text { Parameter } \\
\text { label } \\
\text { (units) }\end{array}$ & $\begin{array}{c}\text { Log- } \\
\text { transformed for } \\
\text { regression }\end{array}$ & Estimated value & $\begin{array}{c}\text { Coefficient } \\
\text { of varlation }\end{array}$ & $\begin{array}{c}\text { 95-percent linear confidence } \\
\text { upper/lower limits on the } \\
\text { estimate }\end{array}$ & $\begin{array}{c}\text { Expected } \\
\text { upper/ower range of } \\
\text { reasonable values }\end{array}$ \\
\hline $\mathrm{K} 1(\mathrm{~m} / \mathrm{d})$ & Yes & 0.275 & 0.149 & $0.369 ; 0.205$ & $100 ; 0.1$ \\
$\mathrm{~K} 2(\mathrm{~m} / \mathrm{d})$ & Yes & $0.443 \times 10^{-1}$ & 0.113 & $0.554 \times 10^{-1} ; 0.354 \times 10^{-1}$ & $0.1 ; 0.0004$ \\
$\mathrm{~K} 3(\mathrm{~m} / \mathrm{d})$ & Yes & $0.562 \times 10^{-2}$ & 0.181 & $0.801 \times 10^{-2} ; 0.394 \times 10^{-2}$ & $0.02 ; 0.0001$ \\
$\mathrm{~K} 4(\mathrm{~m} / \mathrm{d})$ & Yes & $0.856 \times 10^{-4}$ & 0.263 & $0.146 \times 10^{-3} ; 0.501 \times 10^{-4}$ & $1 \times 10^{-4} ; 2 \times 10^{-7}$ \\
$\mathrm{~K} 5(\mathrm{~m} / \mathrm{d})$ & Yes & 21.2 & 0.499 & $0.500 \times 10^{2} ; 0.889 \times 10^{1}$ & $100 ; 8$ \\
$\mathrm{~K} 9(\mathrm{~m} / \mathrm{d})$ & Yes & 0.159 & 0.479 & $0.367 \times 10^{0} ; 0.686 \times 10^{-1}$ & $1 ; 0.01$ \\
$\mathrm{ANIV}$ & Yes & 164 & 0.518 & $399 ; 67.2$ & $1000 ; 1$ \\
$\mathrm{RCH} 2$ (percent) & No & 3.02 & 0.107 & $3.66 ; 2.37$ & $8 ; 1$ \\
$\mathrm{RCH3}$ (percent) & No & 22.7 & 0.0518 & $25.0 ; 20.3$ & $30 ; 15$ \\
\hline
\end{tabular}

\footnotetext{
For parameters that were log-transformed for regression, these are calculated as $\mathrm{s}_{B} / \mathrm{B}$, where $\mathrm{B}$ is the untransformed estimated value, $s^{2}{ }_{B}=\exp \left(s^{2} \ln B+2(\ln B)\right)\left(\exp \left(s^{2} \ln B\right)-1\right.$. ), and $s^{2} \ln B$ is the variance of the log-transformed value estimated by regression.

${ }^{2}$ The confidence intervals are not symmetric about the estimated value for parameters that were log-transformed for the regression.
} 


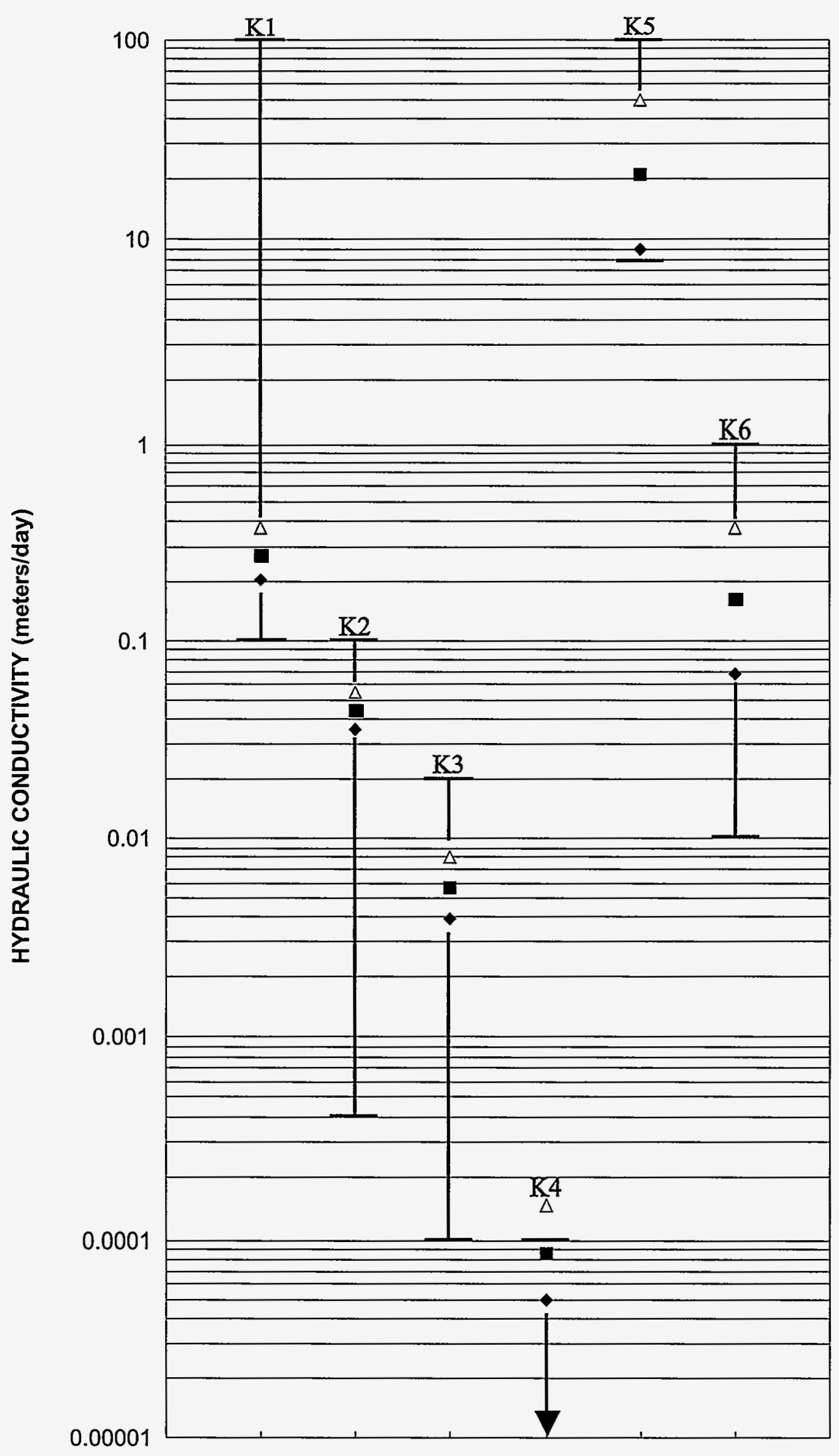

\section{EXPLANATTON}

K1 Parameter number

T Expected range of reasonable values

$\Delta \quad$ Upper limit of linear confidence interval

- Estimated value

Lower limit of linear confidence interval

Figure 59. Estimated hydraulic conductivity parameters, their 95-percent linear confidence intervals, and the range of reasonable values.

110 Hydrogeologic Evaluation and Numerical Simulation of the Death Valley Regional Ground-Water Flow System, Nevada and California 


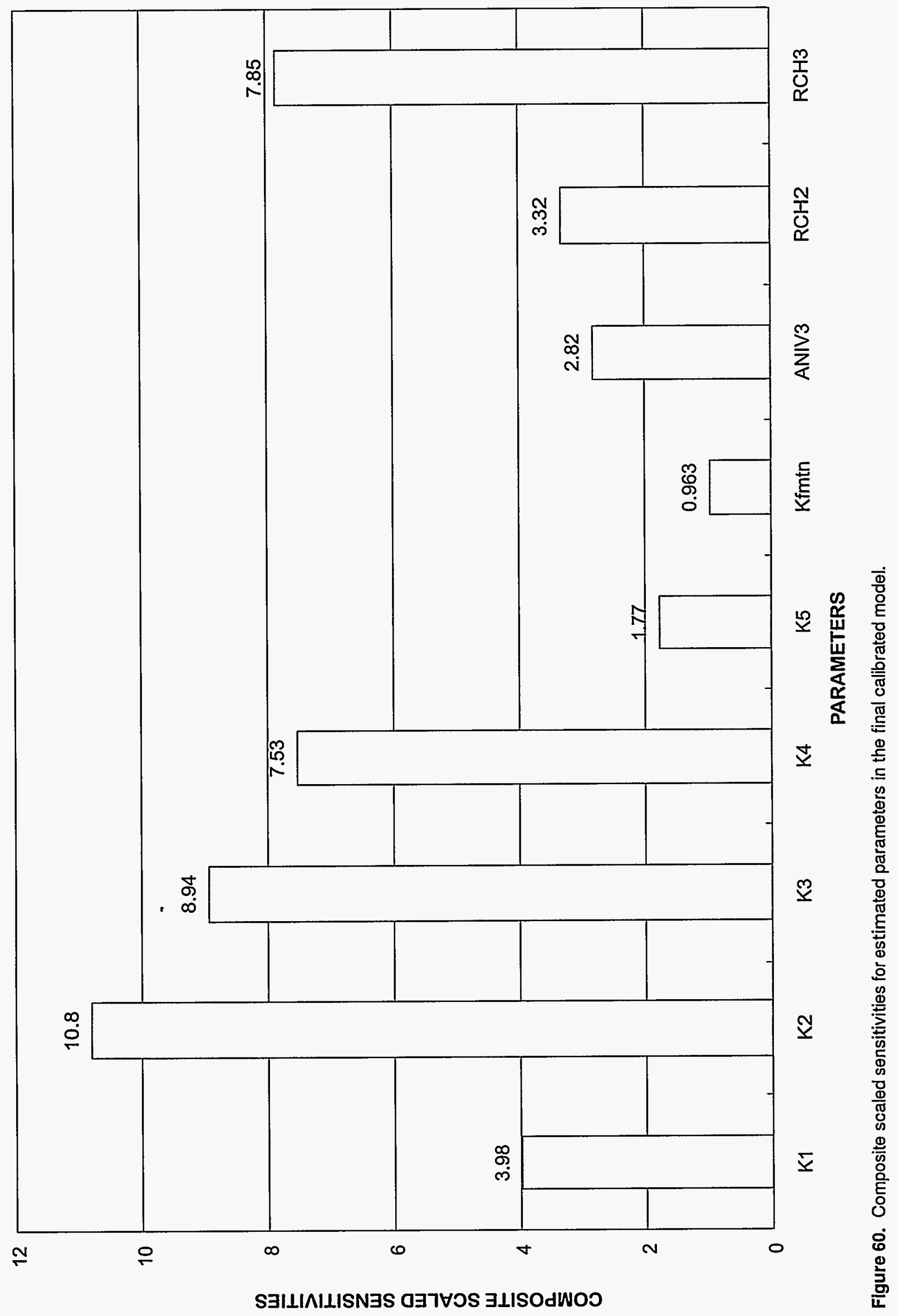




\section{Water Budgets}

The water budget for the model is compared to the estimated budget in table 17. The independently estimated flow out at major discharge areas (including spring flow and ET) is compared to simulated total outflow in table 18. The results shown in table 17 are important because they indicate that although the match between observed and simulated spring flux was not random, as indicated by figure 56 , it appears that the total flux from the major discharge areas is being simulated correctly. Independently, spring flow is smaller than expected and ET is larger than expected. The larger than expected ET volumes may be the result of over-estimating the area where ET is occurring.

From a larger perspective, spring flows are difficult to match in model calibration-indeed, many other simulations of this region impose the fluxes at springs, resulting in cones of depression in the vicinity of the springs. Representation of the flow from the springs as flow originating from the deep system (mostly model layer 3) and ET from the surficial layer (model layer 1) provides a realistic representation of the actual physical processes, and allows for the kind of analysis presented in this report.

Table 17. Water budget for the final simulation compared with estimates from this study

$\left[\mathrm{m}^{3} / \mathrm{d}=\right.$ cubic meters per day $]$

\begin{tabular}{|c|c|c|}
\hline & $\begin{array}{l}\text { Simulated } \\
\left(\mathrm{m}^{3} / \mathrm{d}\right)\end{array}$ & $\begin{array}{l}\text { Estimated } \\
\text { value } \\
\left(\mathrm{m}^{3} / \mathrm{d}\right)\end{array}$ \\
\hline \multicolumn{3}{|l|}{ IN: } \\
\hline $\begin{array}{l}\text { Constant head } \\
\text { (north and east boundaries) }\end{array}$ & 69,000 & 31,900 \\
\hline $\begin{array}{l}\text { Recharge (infiltration modified } \\
\text { Maxey-Eakin) }\end{array}$ & 338,000 & 312,300 \\
\hline TOTAL IN: & 407,000 & 344,200 \\
\hline \multicolumn{3}{|l|}{ OUT: } \\
\hline $\begin{array}{l}\text { Wells (pumping with return } \\
\text { flow included) }\end{array}$ & 88,000 & 89,400 \\
\hline Evapotranspiration & 173,000 & 148,600 \\
\hline Springs (regional) & 51,700 & 125,400 \\
\hline $\begin{array}{l}\text { Constant head } \\
\text { (Death Valley saltpan) }\end{array}$ & 98,000 & 100,000 \\
\hline TOTAL OUT: & 405,000 & 463,400 \\
\hline Difference: & 2,000 & 119,200 \\
\hline
\end{tabular}

Table 18. Total flow (including spring flow and evapotranspiration) at major discharge areas simulated with the final model and estimated for this study

$\left[\mathrm{m}^{3} / \mathrm{d}=\right.$ cubic meters per day $]$

\begin{tabular}{lrr} 
Area & $\begin{array}{c}\text { Simulated } \\
\left(\mathrm{m}^{3} / \mathrm{d}\right)\end{array}$ & \multicolumn{1}{c}{$\begin{array}{c}\text { Expected } \\
\text { values } \\
\left(\mathrm{m}^{3} / \mathrm{d}\right)\end{array}$} \\
\hline 1. Oasis Valley & 14,600 & 14,500 \\
2. Grapevine Springs & 5,900 & 5,000 \\
3. Furnace Creek & 7,600 & 11,000 \\
4. Ash Meadows/Peter's Playa & 145,000 & 130,000 \\
5. Tecopa/Shoshone & 20,000 & 24,000 \\
6. Saratoga Springs & 640 & 680 \\
\hline
\end{tabular}

\section{Summary of Model Evaluation}

The results presented in this section suggest that the DVRFS model reproduces the measured hydraulic heads and estimated water-budget components reasonably accurately. In addition, the estimated parameter values include all aspects of the system that are most important for steady-state simulation, and the parameter values that produce the best match between simulated and observed hydraulic heads and flows, that is, the parameter values estimated by the regression, are all reasonable.

Because the weighted residuals are not entirely random, some model error may be indicated. This is related to the occurrence of large positive weighted residuals for hydraulic heads and large negative weighted residuals for spring flows. In addition, weighted residuals are not normally distributed. These results, combined with the previously discussed observation that every model update considered thus far significantly improved model fit, suggests that additional calibration may significantly improve model accuracy. This analysis suggests that the DVRFS model is a reasonable representation of the physical system, but evidence of important model error exists.

One of the more apparent factors contributing to model error is the vertical discretization of the regional system into three layers. While a three layer model is an improvement on previous $2 \mathrm{D}$ and quasi$3 \mathrm{D}$ models, simplification of the complex 3D hydrogeologic framework into three layers inevitably results in model error, particularly in areas of significant vertical flow components. The introduced model 
error may translate into model bias in computed parameters and all quantities computed using them, particularly head and flux. Furthermore, this potential bias may be contributing to closeness of fit calculated for the model. An evaluation of the extent of model error should be conducted. This evaluation may include a series of cross-sectional or subsystem models with varying degrees of vertical discretization. A comparison of the levels of detail in vertical discretization with the model fit and computed parameter values would give some indication of the potential for model error. An evaluation of this kind would, however, significantly increase the scope of the current study, and should be considered for future work.

\section{SUMMARY}

Yucca Mountain is being studied as a potential site for a high-level radioactive waste repository. In cooperation with the DOE, the USGS is evaluating the geologic and hydrologic characteristics of this site. Because of the potential for radionuclides to be transported by ground water from the repository to the accessible environment, regional and local groundwater flow system dynamics must be evaluated. The purpose of this report is to document the regional hydrologic modeling studies conducted by the USGS as part of the Yucca Mountain site characterization activities. This report documents characterization of the regional hydrogeology and numerical simulation of the present-day ground-water flow system. Hydrogeologic evaluation of the Death Valley regional ground-water flow system was undertaken over an area located along the border of southern Nevada and southeastern California. The study area covers approximately $100,000 \mathrm{~km}^{2}$ between lat $35^{\circ} \mathrm{N}$., long $115^{\circ} \mathrm{W}$. and lat $38^{\circ} \mathrm{N}$., long $118^{\circ} \mathrm{W}$. Yucca Mountain is located near the geographic center of the region. The study area was defined to encompass the Death Valley regional ground-water system.

The Death Valley region is situated within the southern Great Basin, a subprovince of the Basin and Range physiographic province. The arid landscape is dominated by isolated mountain ranges rising abruptly from broad, alluvium-filled desert basins. Altitudes range from $86 \mathrm{~m}$ below sea level at Death Valley to 3,600 $\mathrm{m}$ above sea level at the Spring Mountains. Altitude differences between valleys and adjoining mountains exceed $1,500 \mathrm{~m}$; such abrupt changes may cause relatively steep gradients in the potentiometric surface.

Perennial surface-water is virtually non-existent in the Death Valley region. The Amargosa River, an intermittent stream which has the most consistent stretches of base flow, discharges into the south end of the Death Valley saltpan, the largest playa and one of the few playas that retains perennial water at isolated locations.

The regional climate varies according to altitude and latitude. Northern parts of the region experience warm dry summers and cold dry winters, while hot dry summers and warm dry winters are common further south. Temperatures vary with altitude; low altitudes, such as Death Valley, experience extreme conditions.

Precipitation exceeds $700 \mathrm{~mm} / \mathrm{yr}$ in the Spring Mountains, while a moisture deficit is found in the valleys, where precipitation is often less than $50 \mathrm{~mm} / \mathrm{yr}$. Low humidity, relatively high air temperatures, abundant sunshine, and light to moderate winds produce very high potential evaporation rates. The soils and vegetation of the Death Valley region reflect climatic, geomorphic, and hydrologic factors and influence recharge.

The Death Valley region has a long and active geologic history, including intermittent marine and nonmarine sedimentation, large-scale compressive deformation, plutonism, volcanism, and extensional tectonics. Much of the present-day topography results from late-Cenozoic tectonic activity. Combinations of normal, reverse, and strike-slip faulting, combined with several folding episodes, have resulted in juxtaposition of diverse rock types, of contrasting ages. The physical characteristics of the region were used to classify the rocks and deposits into ten hydrogeologic units: Quaternary playa deposits, Quatemary-Tertiary valley fill, Quaternary-Tertiary volcanic rocks, Tertiary volcanic rocks, Late Tertiary volcanic and volcaniclastic rocks, Tertiary-Late Jurassic granitic rocks, Mesozoic sedimentary and metavolcanic rocks, Paleozoic carbonate rocks, Paleozoic-Precambrian clastic rocks, and Precambrian igneous and metamorphic rocks.

Conceptualization of the geology and groundwater resources of the Death Valley region provides the physical and hydraulic basis for the subsequent numerical analysis of the regional ground-water flow system. The system may be most easily conceptualized as having two main components; a series of 
relatively shallow and localized flow paths that are superimposed on deeper regional flow paths. The Death Valley region lies within the carbonate-rock province of the Great Basin. This province is characterized by thick sequences of carbonate rocks that form a generally deep regional flow system that transfers ground water from northern and eastern Nevada toward the south and west. Regional flows do not coincide with topographic basins; most flow reflects structural and lithologic conditions that produce variations in permeability. Regional flow paths interact with local flow paths reflecting local geologic and topographic controls on recharge and discharge. Pumping for agricultural, commercial, and residential uses introduces new stresses on these ground-water systems. In several places, high mountain ranges support local ground-water mounds that may act as boundaries to ground-water flow.

The conceptual model used by this study assumes that structural controls exert considerable influence on the regional ground-water flow system. Adequate quantitative data are not available to fully test this conceptualization; however, previous studies and observations made during the course of the current study support this hypothesis. Throughout the study area, hydraulic compartmentalization reflects complex geologic structures. Several calderas and resurgent volcanic intrusions forming the SWNVF may have completely removed or altered the carbonate rocks forming the regional aquifer, thereby disrupting portions of the deeper regional flow system. Most spring and discharge features are associated with faults, and many diffuse discharge areas reflect structural controls. Evaluation of crustal stresses in this region suggests that, in general, faults trending $\mathrm{NE} / \mathrm{SW}$ are in relative extension, while those trending NW/SE are in relative compression. In the study area, $\mathrm{NE} / \mathrm{SW}$ trending faults appear to exhibit enhanced porosity and permeability, and become preferential conduits for ground-water flow. The NE/SW trending Spotted Range-Mine Mountain Structural Zone apparently drains adjacent areas by acting as a highly transmissive zone within the regional carbonate aquifer. Cross-cutting the Walker Lane belt are some $\mathrm{NE} / \mathrm{SW}$ trending structural zones that affect regional flow patterns. Ground water is believed to flow into the Death Valley regional flow system from the adjacent White River ground-water system along the NE/SW trending Pahranagat shear zone. In contrast, faults in relative compression may exhibit reduced porosity or permeability, becoming partial barriers to ground-water flow. Springs frequently occur along, or just up gradient of, NW/SE trending faults. At Ash Meadows, numerous springs are found where NE/SW trending faults abut against a NW/SE trending fault.

Hydrogeologic investigations over such a large and hydrogeologically complex area impose severe demands on data management. Spatial and temporal data sets, developed by numerous scientists from different disciplines, exist in various formats. This study utilized GIS and GSIS to develop, store, manipulate, analyze, and model these data sets. Because all relevant data sources were in digital formats, alternative conceptualizations of the hydrogeologic framework or flow-system components were efficiently created and evaluated.

This study utilized GSIS to develop a 3D interpretation of the regional hydrogeology. The 3D digital hydrogeologic framework model provides a description of the geometry, composition, and hydraulic properties of the materials that control the regional ground-water flow system. It serves as an important information source for the development of the flow properties component of the numerical ground-water flow model. Development of the 3D framework model is based on three primary data sources: digital elevation models (DEM), geologic maps and sections, and lithologic well logs. The geologic maps and sections and lithologic well logs were classified into ten hydrogeologic units. Thirtytwo regional interpretive geologic sections, reflecting a consistent interpretation of regional structural style, and approximately 700 lithologic well logs provided the subsurface control for the framework model (fig. 18). Although thousands of faults have been mapped in the region, only 300 were used for offsetting units in the final 3D model definition.

The 3D hydrogeologic framework model defines geology and structures above $10,000 \mathrm{~m}$ below sea level. The model has $1,500 \mathrm{~m}$ horizontal resolution and variable vertical thickness. The model cells are attributed to define both their hydrogeologic units and faulting conditions. Fault traces with lengths greater than $1.5 \mathrm{~km}$ are believed to influence shallow ground-water flows. Cells through which these fault traces pass at depths of less than $1,000 \mathrm{~m}$ are attributed to indicate the presence of these faults. Ground-water flows at greater depths are believed to be affected by major faults. Cells through which these major faults pass at depths between 1,000 and $5,000 \mathrm{~m}$ are coded to 
reflect these faults. At depths greater than $5,000 \mathrm{~m}$, confining pressures are assumed to keep the faults closed.

The 3D hydrogeologic framework is the medium through which the ground water flows. Ground water leaves and enters the Death Valley region by discharge, recharge, or flow across boundaries. Discharges from the regional groundwater flow system occur by ET from phreatophytes and wet playas, by springs fed from regional flow paths, and by pumpage. The Death Valley saltpan has long been recognized as the ultimate discharge for this flow system, but other intermediate discharge areas account for significant water volumes.

Evapotranspiration by plants and evaporative losses from moist playa surfaces account for the greatest volume of water discharged from the groundwater system. Evapotranspiration and bare-soil evaporative rates have not been precisely determined for this region. Water consumption rates developed for nearby areas were used to compute discharge volumes. A map showing potential ET areas was created by combining maps showing locations of selected vegetation classes, high-salinity soils, and locations of known springs. This ET map includes all areas where significant ET volumes may occur from phreatophyte vegetation or moist bare soil.

Springs discharging from perched local groundwater systems were distinguished from springs discharging from the regional saturated zone by using flow and temperature data. A regional springs data base was developed that contained spring discharge rates from numerous sources. A summation of total regional spring discharge was developed for all identified discharge areas.

A map showing water-producing wells was developed from the NWIS data base. Average annual consumptive water-use values for each surface-water basin were estimated and recorded from various sources to produce the best possible estimates of pumping over historical time. The estimated consumptive use rates for each surface-water basin were equally apportioned among the wells located within the basin according to the designated dominant use.

Empirical, water-balance, and distributedparameter methods have been used by others to characterize the location and amount of regional recharge in the Death Valley region. The empirical Maxey-Eakin method remains the most widely-used means of estimating regional ground-water recharge in the Great Basin. In this study, the Maxey-Eakin method was adapted to make it more sensitive to the critical factors believed to control recharge rates, by using data within the GSIS to define altitude, slope and aspect, relative permeability, and vegetation type. The accuracy of the predicted recharge areas was assessed by comparing them to maps showing locations of discharges from locally recharged groundwater systems, and vegetation classes reflecting moist ground. This recharge map defines areas in the Death Valley region where long-term, regional ground-water recharge may occur.

In this sparsely populated region, water resource extraction and investigation have been mostly concentrated in alluvial basins. Clusters of water wells, and hence water-level data, are concentrated in these basins. A new estimated regional potentiometricsurface map was constructed for this study incorporating multiple ancillary data sets to help estimate water levels in data-poor areas. These ancillary data sets include lakes, springs, altitude, recharge areas, discharge areas, and hydrogeology. Water level data for 2,141 wells within the study area were retrieved from NWIS. Most measured water levels were considered to represent the water table, or to be composite water-level measurements of the regional potentiometric surface. Approximately 171 wells are completed to depths greater than $500 \mathrm{~m}$ below static water level and are believed to represent potentiometric levels from deeper portions of the flow system. An automated gridding and contouring software package was used to initially interpolate the data. Numerous intermediate gridding steps were conducted, and adjustments made using handcontouring methods that reflected the ancillary data. The resulting potentiometric-surface map conforms to this study's conceptualization of the regional groundwater flow system.

The Death Valley regional flow system consists of ground water moving through a 3D body of consolidated and unconsolidated materials. The 3D hydrogeologic framework model describes the characteristics of this saturated volume. The upper boundary of the flow system is the water table. The lower boundary of the flow system is located at a depth where ground-water flow is dominantly horizontal and moves with such small velocities that the volumes of water involved do not significantly impact regional flow estimates. The lateral limits of the regional flow 
system may be either no-flow or potential-flow boundaries. No-flow conditions exist where groundwater movement across the boundary is prevented by physical barriers or divergence of ground-water flow paths. Flow exists where ground-water potentiometric gradients permit flow across a boundary.

For purposes of conceptualization and subsequent numerical simulation, the limits of the flow system for this study were selected based on reevaluation of previously defined flow system boundaries, the potentiometric surface developed for this study, and the hydrogeologic framework model. Very little hard data exist to support a precise definition of the western extent of the flow system. The western boundary of the flow system is therefore placed to coincide with the eastern edge of the Death Valley saltpan which is interpreted as the terminal sink of the flow system.

The Death Valley regional ground-water flow system is subdivided into three major subregional flow systems. Description of the source, occurrence and movement of ground water in the Death Valley regional ground-water flow system is most easily undertaken according to the subregions, but these subdivisions are for descriptive purposes only and do not define discrete, independent flow systems. Each subregion name reflects the part of Death Valley into which it discharges. Because the Central Death Valley subregion is so large, it is divided into three groundwater basins. The subregions, or the ground-water basins, are further divided into sections. Flow in each subregion has clearly defined flow paths.

The water budget for the Death Valley regional ground-water flow system is difficult to compute, because inflow and outflow volumes are poorly defined for many areas. In addition, the large size of this regional system precludes the comprehensive and accurate assessment of all inflows to and outflows from the system. Previous attempts to estimate water budgets for various parts of the flow system did not use consistent boundaries, so the budgets cannot be readily compared. This study uses a lumped-budget approach; each component of the ground-water budget, such as ET, is defined by a single lumped value even though it may have been calculated originally for separate areas in the basin. This lumped-budget approach permits an encapsulated view of the system, but errors are inevitable in the estimates. Short of physical measurements modeling is probably the best means of resolving these errors.
The Death Valley regional ground-water flow system was conceptualized and analyzed using a 3D steady-state simulation model that incorporated a nonlinear least squares regression technique to estimate aquifer variables (or parameters). The USGS numerical modeling program MODFLOWP was used to create a finite-difference model consisting of 163 rows, 153 columns, and three layers. The grid cells were oriented north-south and were of uniform size, with side dimensions of $1,500 \mathrm{~m}$. The layers represented conditions at $0-500 \mathrm{~m}, 500-1,250 \mathrm{~m}$, and $1,250-2,750 \mathrm{~m}$ below the estimated water table. The first and second layers were designed to simulate local and subregional flow paths mostly within valley-fill alluvium, volcanic rocks, and shallow carbonate rocks. The third (lowest) layer simulates deep regional flow paths in the volcanic, carbonate, and clastic rocks.

The required DVRFS model parameter values were supplied by discretization of the 3D hydrogeologic framework model and digital representations of the remaining conceptual model components. The primary objective of the numerical simulation was to evaluate the perceived 3D nature of the flow system. The 3D simulation supported the analysis of interactions between the relatively shallow local and subregional flow paths and the deeper dominant regional flow paths controlled by the carbonate aquifer.

The hydrogeologic conditions represented in the 3D framework model vary considerably within the volumes represented by each of the three layers in the numerical simulation model. MODFLOWP zone arrays were used to simplify this complexity. Initially, eight RCU's were computed to reflect dominant conditions within the layer, including hydrogeologic unit, depth, and presence or absence of significant faulting. Subsequently, to further reduce the number of parameters subjected to estimation by the model, these eight RCU's were reclassified to form four hydraulic conductivity zones. These zones are not contiguous; each includes cells distributed throughout the model.

Identical model boundary locations occur in all three layers. All boundaries in the top layer were designated as no-flow except along the western side of the model in Death Valley where constant-head values were selected. No ground water is believed to enter or exit the Death Valley system at intermediate depths, so all the boundaries in the middle layer were set to noflow conditions. In layer three, the boundaries were 
set to no-flow conditions except at four locations along the northern and eastern limits of the model, where the conceptual model suggests inter-connections with adjacent systems along buried zones of higher permeability. Flow conditions between layers were not explicitly defined; the MODFLOWP program is capable of defining such interactions by internally computed VCONT arrays.

Model source and sink parameters defining recharge, ET, spring-flow discharge, and ground-water pumpage were obtained from the digital GIS data base ET estimates were developed from land-surface altitudes, extinction depth values, and maximum ET rate maps created within the GIS. The recharge potential map was reclassified to produce a recharge array that contained four zones ranging from high to no recharge potential. For each zone a parameter could be assigned to represent the percentage of precipitation that infiltrates, and a second array was used to define the variation expected in the recharge rates. Spring discharge rates were obtained from historical records. Springs were specified using the general-head boundary package; this required information defining the altitude of the spring orifice and conductance. Because the conductance values were poorly known, springs were grouped by geographic location and a single conductance value was assigned to each group. The amount of pumpage was simulated using the well package, and all pumping wells were assigned to the first (uppermost) layer. Return flows were accounted for by specifying percentages of pumped water that is permanently removed from the system.

Calibration of the DVRFS model using the techniques available in MODFLOWP allowed for estimation of a series of parameters that provide a best fit to observed hydraulic heads and flows. Numerous conceptual models were evaluated during calibration to test the validity of various interpretations about the flow system. Conceptual model evaluations focused on testing hypotheses concerning the (1) the location and type of flow system boundaries, (2) the extent and location of recharge areas, and (3) the configuration of hydrogeologic framework features. For each hypothesis tested, a new set of parameters was estimated using MODFLOWP and the resulting new simulated heads and flows were compared to observed values. Only those conceptual model changes contributing to a significant improvement in model fit, as indicated by a reduction in the sum of squared errors, were retained in the final optimized model.
The final model was evaluated to assess the likely accuracy of simulated results. This was accomplished by comparing measured and expected quantities with simulated values. The quantities included in these comparisons are (1) hydraulic heads and spring flows, which were matched by regression; (2) hydraulic conductivities, which were represented by parameters that were estimated in the regression; and (3) water budgets. Unweighted and weighted residuals for hydraulic heads show a very good model match with observed conditions in flat hydraulic gradient areas and a relatively good match in large hydraulic gradient areas. Weighted and unweighted residuals for spring flows shows somewhat of a bias in that simulated spring flows are generally lower than observed. The difficulty in simulating these spring flows in previous models of this area without imposing discharge by using a specified flux, however, suggests that even the somewhat lower simulated discharges are an improved match with observed conditions. Estimated parameters were evaluated to determine if reasonable values were estimated for values of hydraulic conductivity, vertical anisotropy and recharge rates. All estimated parameter values are within expected ranges. The MODFLOWP-calculated linear confidence intervals also were well within the range of expected values. Water budgets were evaluated to determine if they were within the range of expected values. Model results suggest that even with the limited understanding of fluxes in and out of the regional ground-water flow system, overall budgets are within the expected ranges for the flow system.

Problems with the DVRFS model are indicated by weighted residuals that are not entirely random, indicating some model error. This is related to the occurrence of large positive weighted residuals for hydraulic heads, where simulated hydraulic heads are distinctly lower than the observed values, and large negative weighted residuals for spring flows, where simulated flows are distinctly less than observed flows. The problem is also related to nonnormally distributed less extreme weighted residuals. These results, combined with the previously discussed observation that every model update considered thus far significantly improved model fit, suggests that additional calibration may significantly improve model accuracy. This analysis suggests that the model is a reasonable representation of the physical system, but evidence of important model error exists. 


\section{REFERENCES CITED}

Ball, S.H., 1907, A geologic reconnaissance in southwestern Nevada and eastern California: U.S. Geological Survey Bulletin 308, 218 p., 3 pls.

Bard, Jonathon, 1974, Nonlinear parameter estimation: New York, Academic Elsevier, 476 p.

Beatley, J.C., 1976, Vascular plants of the Nevada Test Site and central-southern Nevada-Ecologic and geographic distributions: Technical Information Center, Office of Technical Information, Energy Research and Development Administration, Springfield, Va., p. 308.

Bedinger, M.S., Harrill, J.R., and Thomas, J.M., 1984a, Maps showing ground-water units and withdrawal, Basin and Range Province, Nevada: U.S. Geological Survey Water-Resources Investigations Report 83-4119-A, 10 p., 2 sheets, scale 1:500,000.

Bedinger, M.S., Langer, W.H., and Moyle, W.R., 1984b, Maps showing ground-water units and withdrawal, Basin and Range Province, southern California: U.S. Geological Survey Water-Resources Investigations Report 83-4116-A, 6 p., scale 1:500,000.

Bedinger, M.S., Langer, W.H., Moyle, W.R., Woolfenden, L.R., and Mulvihill, D.A., 1984c, Maps showing ground-water levels, springs, and depth to ground water, Basin and Range Province, Nevada: U.S. Geological Survey Water-Resources Investigations Report 83-4116-B, 10 p., 2 sheets, scale 1:500,000.

Bedinger, M.S., Langer, W.H., and Reed, J.E., 1989a, Ground-water hydrology, in Bedinger, M.S., Sargent, K.A., and Langer, W.H., eds., Studies of geology and hydrology in the Basin and Range Province, Southwestern United States, for isolation of high-level radioactive waste-Characterization of the Death Valley region, Nevada and California: U.S. Geological Survey Professional Paper 1370-F, p. 28-35.

$-1989 \mathrm{~b}$, Hydraulic properties of rocks in the Basin and Range Province, in Bedinger, M.S., Sargent, K.A., Langer, W.H., Sherman, F.B., Reed, J.E., and Brady, B.T., eds., Studies of geology and hydrology in the Basin and Range Province, southwestern United States, for isolation of high-level radioactive waste-Basis of characterization and evaluation: U.S. Geological Survey Professional Paper 1370-A, p. 16-18.

Bedinger, M.S., Sargent, K.A., and Langer, W.H., 1989c, Studies of geology and hydrology in the Basin and Range Province, Southwestern United States, for isolation of high-level radioactive waste-Characterization of the Death Valley region, Nevada and California: U.S. Geological Survey Professional Paper 1370-F, $49 \mathrm{p}$.
Bedinger, M.S., Sargent, K.A., Langer, W.H., Sherman, F.B., and Brady, B.T., 1989d, Regional characterization and guidelines for evaluation, in Bedinger, M.S., Sargent, K.A., Langer, W.H., Sherman, F.B., Reed, J.E., and Brady, B.T., eds., Studies of geology and hydrology in the Basin and Range Province, Southwestern United States, for isolation of high-level radioactive wasto-Basis of characterization and evaluation: U.S. Geological Survey Professional Paper 1370-A, p. 6-15.

Benson, Lyman, and Darrow, R.A., 1981, Trees and shrubs of the southwestern deserts: Tucson, University of Arizona Press, $416 \mathrm{p}$.

Bentley, C.B., 1984, Geohydrologic data for test well USW G-4, Yucca Mountain area, Nye County, Nevada: U.S. Geological Survey Open-File Report 84-063, $48 \mathrm{p}$.

Bentley, C.B., Robison, J.H., and Spengler, R.W., 1983, Geohydrologic data for test well USW H-5, Yucca Mountain area, Nye County, Nevada: U.S. Geological Survey Open-File Report 83-853, 34 p.

Blankennagel, R.K., and Weir, J.E. Jr., 1973, Geohydrology of the eastern part of Pahute Mesa, Nevada Test Site, Nye County, Nevada: U.S. Geological Survey Professional Paper 712-B, $35 \mathrm{p}$.

Burchfiel, B.C., and Davis, G.A., 1981, Mojave desert and environs, in Ernst, W.G., ed., The geotectonic development of California, Rubey v. 1: Englewood Cliffs, N.J., Prentice-Hall, p. 217-252.

Burrough, P.A., 1986, Principles of geographical information systems for land resources assessment: New York, Oxford University Press, 194 p.

Carpenter, Everett, 1915, Ground water in southeastern Nevada: U.S. Geological Survey Water-Supply Paper 365,86 p., 5 pls.

Carr, W.J., 1982, Structural setting and rate of tectonic activity in the Yucca Mountain region, southwestern Great Basin, Nevada and California: EOS, v. 63, no. 10, p. 99. 1984, Regional structural setting of Yucca Mountain, southwestern Nevada, and late Cenozoic rates of tectonic activity in part of the southwestern Great Basin, Nevada and California: U.S. Geological Survey Open-File Report 84-854, 114 p. 1988, Volcano-tectonic setting of Yucca Mountain and Crater Flat, southwestern Nevada, in Carr, M.D., and Yount, J.C., eds., Geologic and hydrologic investigations of a potential nuclear waste disposal site at Yucca Mountain, southern Nevada: U.S. Geological Survey Bulletin 1790, p. 35-49.

1990, Styles of extension in the Nevada Test Site region, southern Walker Lane Belt—An integration of volcano-tectonic and detachment fault models, in Wernicke, B.P., ed., Basin and Range extensional 
tectonics near the latitude of Las Vegas, Nevada: Boulder, Colo., Geological Society of America, Memoir 176, chap. 13, p. 283-303.

Christensen, S., and Cooley, R.L., 1996, Simultaneous confidence intervals for a steady-state leaky aquifer groundwater flow model, in Kovar, Karel, and van der Heidje, Paul, eds.: Proceedings of the Model CARE Conference, Golden Colo., September 1996.

Claassen, H.C., 1983, Sources and mechanisms of recharge for ground water in the west-central Amargosa Desert, Nevada-A geochemical interpretation: U.S. Geological Survey Open-File Report 83-542, 61 p.

Clebsch, A., Jr., and Barker, F.B., 1960, Analyses of ground water from Rainier Mesa, Nevada Test Site, Nye County, Nevada: U.S. Geological Survey Open-File Report TEI-763.

Cooley, R.L., and Naff, R.L., 1990, Regression modeling of ground-water flow: U.S. Geological Survey Techniques of Water-Resources Investigations, book 3 , chap. B4, 232 p.

Craig, R.W., and Johnson, K.A., 1984, Geohydrologic data for test well UE-25p \#1, Yucca Mountain area, Nye County, Nevada: U.S. Geological Survey Open-File Report 84-450, $63 \mathrm{p}$.

Craig, R.W., and Robinson, J.H., 1984, Geohydrology of rocks penetrated by test well UE-25p \#1, Yucca Mountain area, Nye County, Nevada: U.S. Geological Survey Water-Resources Investigations Report 84-4248, $57 \mathrm{p}$.

Craig, R.W., Reed, R.L., and Spengler, R.W., 1983, Geohydrologic data for test well USW H-6, Yucca Mountain area, Nye County, Nevada: U.S. Geological Survey Open-File Report 83-856, 35 p.

Czarnecki, J.B., 1990, Geohydrology and evapotranspiration at Franklin Lake Playa, Inyo County, California: U.S. Geological Survey Open-File Report 90-356, $96 \mathrm{p}$.

Czarnecki, J.B., and Waddell, R.K., 1984, Finite-element simulation of ground-water flow in the vicinity of Yucca Mountain, Nevada-California: U.S. Geological Survey Water-Resources Investigations Report 84-4349, $38 \mathrm{p}$.

Czarnecki, J.B., and Wilson, W.E., 1991, Conceptual models of the regional ground-water flow and planned studies at Yucca Mountain, Nevada: Hydrological Science and Technology, v. 7, no. 1-4, p. 15-25.

D'Agnese, F.A., 1994, Using geoscientific information systems for three-dimensional modeling for regional ground-water flow system, Death Valley region, Nevada and California: Golden, Colorado School of Mines, $\mathrm{Ph} . \mathrm{D}$ dissertation, $331 \mathrm{p}$.
D’Agnese, F.A., Faunt, C.C., and Turner, A.K., 1995, Preliminary digital geologic maps of the Mariposa, Kingman, Trona, and Death Valley Sheets, California: U.S. Geological Survey Open-File Report 94-318, $19 \mathrm{p}$. 1996, Using remote sensing and GIS techniques to estimate discharge and recharge fluxes for the Death Valley regional groundwater flow system, USA-HydroGIS 96: Proceedings of the Vienna Conference, April 1996, LAHS Publ. no. 235, p. 503-511.

Denny, C.S., and Drewes, Harold, 1965, Geology of the ash meadows quadrangle Nevada-California: U.S. Geological Survey Bulletin 1181-L, 56 p.

Dettinger, M.D., 1989, Distribution of carbonate-rock aquifers in southern Nevada and the potential for their development, Summary of Findings, 1985-88, Program for the study and testing of carbonate-rock aquifers in eastern and southern Nevada, Summary Report No. 1: Carson City, State of Nevada, $37 \mathrm{p}$.

Dickinson, W.R., and Snyder, W.S., 1979, Geometry of triple junctions related to the San Andreas transform: Journal of Geophysical Research, v. 84, p. 561-572.

Downey, J.S., Kolm, K.E., and Gutentag, E.D., 1990, Selection of geohydrologic boundaries for groundwater flow models, Yucca Mountain, Nevada: Tucson, University of Arizona, Proceedings of Waste Management '90, v. 2, p. 725-734.

Draper, Norman, and Smith, Harry, 1981, Applied regression analysis ( $2 \mathrm{~d}$ ed.): New York, Wiley-Interscience, $709 \mathrm{p}$.

Dudley, W.W., Jr., and Larson, J.D., 1976, Effects of irrigation pumping on desert pupfish habitats in Ash Meadows, Nye County, Nevada: U.S. Geological Survey Professional Paper 927, $52 \mathrm{p}$.

Duell, L.F., Jr., 1990, Estimates of evapotranspiration in alkaline scrub and meadow communities of Owens Valley, California, using the Bowen-ratio, eddycorrelation, and Penman-combination methods: U.S. Geological Survey Water-Supply Paper 2370-E, $39 \mathrm{p}$.

Eakin, T.E., 1966, A regional interbasin groundwater system in the White River area, southeastern Nevada: Water Resources Research v. 2, no. 2, p. 251-271.

Eakin, T.E., and Moore, D.O., 1964, Uniformity of discharge of Muddy River Springs, southeastern Nevada, and relation to interbasin movement of ground water: U.S. Geological Survey Professional Paper 501-D, p. D171-D176.

Eakin, T.E., Price, Don, and Harrill, J.R., 1976, Summary appraisals of the Nation's ground-water resources-Great Basin region: U.S. Geological Survey Professional Paper 813-G, 37 p. 
Eakin, T.E., Schoff, S.L., and Cohen, Philip, 1963, Regional hydrology of a part of southern Nevada-A reconnaissance: U.S. Geological Survey Trace-Element Investigations Report TEI 833, $40 \mathrm{p}$.

Eakin, T.E., and Winograd, I.J., 1965, Interbasin movement of ground water in south central Nevada-Some implications: Geological Society of America Special Paper 82, 52 p.

Faunt, C.C., 1994, Characterization of the threedimensional hydrogeologic framework of the Death Valley region, Nevada and California: Golden, Colorado School of Mines, Ph.D. dissertation, $235 \mathrm{p}$.

Faunt, C.C., in press, Effect of faulting on ground-water movement in the Death Valley region, Nevada and California: U.S. Geological Survey Water-Resources Investigations Report 95-4132.

Faunt, C.C., D'Agnese, F.A., and Turner, A.K., in press, A hydrogeologic map of the Death Valley region, Nevada and California —Developed using GIS techniques: U.S. Geological Survey Water-Resources Investigations Report 95-4016.

Fenneman, N.M., 1931, Physiography of Western United States: New York, McGraw-Hill, 534 p.

Fiero, G.W., Jr., Illian, J.R., Dinwiddie, G.A., and Schroder, L.J., 1974, Use of hydrochemistry for interpreting ground-water flow systems in central Nevada: U.S. Geological Survey Open-File Report 474-178, 44 p.

French, R.H., 1983, A preliminary analysis of precipitation in southern Nevada: Water Resources Center, Desert Research Institute, DOE/NV/10162-10, 42 p.

Fried, C.C., and Leonard, J.E., 1990, Petroleum 3-D models come in many flavors: Geobyte, v. 5, no. 1, p. 27-30.

Galloway, Devin, 1993, Earth-tide induced fluid-pressure changes in Devils Hole, Death Valley National Monument, California-Nevada: American Geophysical Union Abstracts 1993 Annual Fall Meeting, p. 565.

Glancy, P.A., 1968, Water-resources appraisal of MesquiteIvanpah Valley area, Nevada and California: Nevada Department of Conservation and Natural Resources, Water Resources-Reconnaissance Series Report 46, $57 \mathrm{p}$.

Grose, T.L., 1983, Thirty-two geologic cross-sections, Clark, Esmeralda, Lincoln, Mineral, and Nye Counties, Nevada and adjacent areas in California: Nevada Bureau of Mines and Geology Open-File Report 83-13.
Grose, T.L., and Smith, G.I., 1989, Geology, in Bedinger, M.S., Sargent, K.A., and Langer, W.H., eds., Studies of geology and hydrology in the Basin and Range Province, Southwestern United States, for isolation of high-level radioactive waste-Characterization of the Death Valley region, Nevada and California: U.S. Geological Survey Professional Paper 1370-F, p. 5-19.

Grove, D.B., Rubin, M., Hanshaw, B.B., and Beetem, W.A., 1969, Carbon-14 dates of ground water from a Paleozoic carbonate aquifer, south central Nevada: U.S. Geological Survey Professional Paper 650-C, p. C215-C218.

Hales, J.R., Jr., 1972, Surges of maritime tropical air northward over the Gulf of California: Monthly Weather Review, v. 100, p. 298-306.

-1974, Southwestern United States summer monsoon source-Gulf of Mexico or Pacific Ocean?: Journal of Applied Meteorology, v. 13, p. 331-342.

Harbaugh, J.W., and Bonham-Carter, Graeme, 1970, Computer simulation in geology: New York, John Wiley, $476 \mathrm{p}$.

Harrill, J.R., 1986, Ground-water storage depletion in Pahrump Valley, Nevada-California, 1962-1975: U.S. Geological Survey Water-Supply Paper 2279, 53 p.

Harrill, J.R., Gates, J.S., and Thomas, J.M., 1988, Major ground-water flow systems in the Great Basin region of Nevada, Utah, and adjacent States: U.S. Geological Survey Hydrologic Investigations Atlas HA-694-C, scale 1:1,000,000.

Hill, M.C., 1992, A computer program (MODFLOWP) for estimating parameters of a transient, threedimensional, ground-water flow model using nonlinear regression: U.S. Geological Survey Open-File Report 91-484, $358 \mathrm{p}$.

1994, Five computer programs for testing weighted residuals and calculating linear confidence and prediction intervals on results from the ground-water parameter-estimation computer program MODFLOWP: U.S. Geological Survey Open-File Report 93-481, $81 \mathrm{p}$.

Hollett, K.J., Danskin, W.R., McCaffrey, W.F., and Walti, C.L., 1991, Geology and water resources of Owens Valley, California: U.S. Geological Survey Water-Supply Paper 2370-B, $77 \mathrm{p}$.

Hunt, C.B., and Robinson, T.W., 1960, Possible interbasin circulation of ground water in the southern part of the Great Basin: U.S. Geological Survey Professional Paper 400-B, p. B273-B274.

Hunt, C.B., Robinson, T.W., Bowles, W.A., and Washburn, A.L., 1966, Hydrologic basin, Death Valley, California: U.S. Geological Survey Professional Paper 494-B, 138 p. 
Jennings, C.W., 1961, Geologic map of California-Kingman sheet: California Division of Mines and Geology, scale $1: 250,000$.

Jennings, C.W., Burnett, J.L., and Troxel, B.W., 1962, Geologic map of California-Trona sheet: California Division of Mines and Geology, scale 1:250,000.

Kilroy, K.C., 1991, Ground-water conditions in Amargosa Desert, Nevada-California, 1952-87: U.S. Geological Survey Water-Resources Investigations Report 89-4101, $91 \mathrm{p}$.

Kirk, S.T., and Campana, M.E., 1990, A deuteriumcalibrated ground-water flow model of a regional carbonate-alluvial system: Journal of Hydrology, v. 119, p. 357-388.

Kohler, M.A., Nordenson, T.J., and Baker, D.R., 1959, Evaporation maps for the United States: U.S. Weather Bureau Technical Paper 37, 13 p.

Lahoud, R.G., Lobmeyer, D.H., and Whitfield, M.S., Jr., 1984, Geohydrology of volcanic tuff penetrated by test well UE-25b \#1, Yucca Mountain, Nye County, Nevada: U.S. Geological Survey Water-Resources Investigations Report 84-4253, 44 p.

Langer, W.H., Moyle, W.R., Woolfenden, L.R., and Mulvihill, D.A., 1984, Maps showing ground-water levels, springs, and depth to ground water, Basin and Range Province, southern California: U.S. Geological Survey Water-Resources Investigations Report 83-4119-B, scale 1:500,000.

Leavesley, G.H., Lichty, R.W., Troutman, B.M., and Saindon, L.G., 1983, Precipitation-runoff modeling system-User's manual: U.S. Geological Survey Water-Resources Investigations Report 83-4238, $207 \mathrm{p}$.

Lichty, R.W., and McKinley, P.W., 1995, Estimates of ground-water recharge rates for two small basins in central Nevada: U.S. Geological Survey WaterResources Investigations Report 94-4104, 31 p.

Lobmeyer, D.H., Whitfield, M.S., Jr., Lahoud, R.G., and Bruckheimer, Laura, 1983, Geohydrologic data for test well UE-25b \#1, Nevada Test Site, Nye County, Nevada: U.S. Geological Survey Open-File Report $83-855,48 \mathrm{p}$.

Lock, Augustus, Billingsley, P.R., and Mayo, E.B., 1940, Sierra Nevada tectonic patterns: Geological Society of America Bulletin, v. 51, p. 513-540.

Loeltz, O.J., 1960, Source of water issuing for springs in Ash Meadows Valley, Nye County, Nevada: Geological Society of America Bulletin 71, p. 1917-1918.

Longwell, C.R., 1960, Possible explanation of diverse structural patterns in southern Nevada: American Journal of Science, v. 258-A, p. 192-203.
Luckey, R.R., Tucci, Patrick, Faunt, C.C., Ervin, E.M., Steinkampf, W.C., D'Agnese, F.A., and Patterson, G.L., 1996, Status of understanding of the saturatedzone ground-water flow system at Yucca Mountain, Nevada as of 1995: U.S. Geological Survey WaterResources Investigations Report 96-4077, 71 p.

Malmberg, G.T., 1967, Hydrology of the valley-fill and carbonate-rock reservoirs, Pahrump Valley, NevadaCalifornia: U.S. Geological Survey Water-Supply Paper $1832,47 \mathrm{p}$.

Malmberg, G.T., and Eakin, T.E., 1962, Ground-water appraisal of Sarcobatus Flat and Oasis Valley, Nye and Esmeralda Counties, Nevada: Nevada Department of Conservation and Natural Resources, Ground-Water Resources, Reconnaissance Series Report 10,39 p.

Maxey, G.B., 1968, Hydrogeology of desert basins: Ground Water, v. 6, no. 5 , p. $10-22$.

Maxey, G.B., and Eakin T.E., 1949, Ground water in White River Valley, White Pine, Nye, and Lincoln Counties, Nevada: Nevada State Engineer Water-Resources Bulletin no. $8,59 \mathrm{p}$.

Maxey, G.B., and Jameson, C.H., 1948, Geology and water resources of Las Vegas, Pahrump, and Indian Springs Valleys, Clark and Nye Counties, Nevada: Nevada State Engineer Water-Resources Bulletin no. $5 ., 43$ p.

Maxey, G.B., and Mifflin, M.D., 1966, Occurrence and movement of ground water in carbonate rocks of Nevada: National Speleological Society Bulletin 28 , no. 3, p. 141-157.

McDonald, M.G., and Harbaugh, A.W., 1988, A modular three dimensional finite-difference ground-water flow model: U.S. Geological Survey Techniques of WaterResources Investigations, book 6, chap. A1, $576 \mathrm{p}$.

Meinzer, O.E., 1917, Geology and water resources of Big Smoky, Clayton, and Alkali Spring Valleys, Nevada: U.S. Geological Survey Water-Supply Paper 423, 167 p., 15 pls.

-1923, Outline of ground-water hydrology, with definitions: U.S. Geological Survey Water-Supply Paper 494, $71 \mathrm{p}$.

Mendenhall, W.C., 1909, Some desert watering places in southeastern California and southern Nevada: U.S. Geological Survey Water-Supply Paper 224, 98 p.

Mifflin, M.D., 1988, Region 5, Great Basin, in Back, William, Rosenshein, J.S., and Seaber, P.R., eds., Hydrogeology: Boulder, Colo., Geological Society of America, The geology of North America, v. O-2, p. 69-78.

Mifflin, M.D., and Hess, J.W., 1979, Regional carbonate flow systems in Nevada: Journal of Hydrology, v. 43, p. 217-237.

Miller, G.A., 1977, Appraisal of the water resources of Death Valley, California-Nevada: U.S. Geological Survey Open-File Report 77-728, 68 p. 
Moore, G.E., 1961, Records of wells, test holes, and springs in the Nevada Test site and surrounding area: U.S. Geological Survey Open-File Report TEI-781, 22 p.

Munz, P.A., 1974, A flora of southern California: Berkeley, University of California Press, $1086 \mathrm{p}$.

Naff, R.L., 1973, Hydrogeology of the southern part of Amargosa Desert in Nevada: Reno, University of Nevada, Master's thesis, 207 p. [unpublished]

Naff, R.L., Maxey, G.B., and Kaufmann, R.F., 1974, Interbasin ground-water flow in southern Nevada: Nevada Bureau of Mines and Geology Report 20, 28 p.

Oberlander, P.L., 1979, Development of a quasi threedimensional groundwater model for a portion of the Nevada Test Site: Reno, Nev., Desert Research Institute, $72 \mathrm{p}$.

Paradis, A.R., and Belcher, R.C., 1990, Interactive volume modeling-A new product for 3-D mapping: Geobyte, v. 5., no. 1, p. 42-44.

Peterman, Z.E., and Stuckless, J.S., 1992, Applications of strontium and other radiogenic tracer isotopes to paleohydrologic studies-Paleohydrogeological methods and their applications: Nuclear Energy Agency Workshop, Paris, France, November 9-10, 1992, Proceedings, p. 59-84.

1992a, Strontium isotope characterization of flow systems in southern Nevada, USA: Mineralogical Magazine, v. 58A, p. 711-712.

Peterson, F.F., 1981, Landforms of the Basin and Range province defined for soil survey: Reno, University of Nevada, Nevada Agricultural Bulletin no. 28, 53 p.

Pistrang, M.A., and Kunkel, Fred, 1964, A brief geologic and hydrologic reconnaissance of the Furnace Creek Wash area, Death Valley National Monument, California: U.S. Geological Survey Water-Supply Paper 1779-Y, $35 \mathrm{p}$.

Plume, R.W., and Carlton, S.M., 1988, Hydrogeology of the Great Basin region of Nevada, Utah, and adjacent States: U.S. Geological Survey Hydrologic Investigations Atlas 694-A.

Poeter, E.P., and Hill, M.C., 1996, Unrealistic parameter values in inverse modeling-A problem of benefit for model calibration: Proceedings of the 1996 Model CARE Conference, Golden, Colo., September 1996.

Prudic, D.E., Harrill, J.R., and Burbey, T.J., 1993, Conceptual evaluation of regional ground-water flow in the carbonate-rock province of the Great Basin, Nevada, Utah, and adjacent States: U.S. Geological Survey Open-File Report 90-560, $103 \mathrm{p}$.

Quiring, R.F., 1965, Annual precipitation amount as a function of elevation in Nevada south of 38-1/2 latitude, Las Vegas, Nevada: U.S. Weather Bureau Research Statistics, 14 p.
Reheis, M.C., and Noller, J.S., 1991, Aerial photographic interpretation of lineaments and faults in late Cenozoic deposits in the eastern part of the Benton Range 1:100,000 quadrangle and the Goldfield, Last Chance Range, Beatty, and Death Valley Junction 1:100,000 quadrangles, Nevada and California: U.S. Geological Survey Open-File Report 90-41, 9 p.

Rice, W.A., 1984, Preliminary two-dimensional regional hydrologic model of the Nevada Test Site and vicinity: Albuquerque, N.Mex., Sandia National Laboratories Report SAND83-7466, 89 p.

Robinson, T.W., 1958, Phreatophytes: U.S. Geological Survey Water-Supply Paper 1423, 84 p.

Robison, J.H., 1984, Ground-water level data and preliminary potentiometric-surface maps, Yucca Mountain and vicinity, Nye County, Nevada: U.S. Geological Survey Water-Resources Investigations Report 84-4197, 8 p.

Rush, F.E., 1968, Index of hydrographic areas in Nevada: Carson City, Nevada Department of Conservation and Water Resources, Water Resources Information Series Report 6, 38 p.

1970, Regional ground-water systems in the Nevada Test Site area, Nye, Lincoln, and Clark Counties, Nevada: Carson City, Nevada Department of Conservation and Water Resources, Water Resources Reconnaissance Series Report 54, 25 p.

Rush, F.E., Thordarson, William, and Bruckheimer, Laura, 1983, Geohydrologic and drill-hole data for test well USW H-1, adjacent to Nevada Test Site, Nye County, Nevada: U.S. Geological Survey Open-File Report 83-141, 38 p.

Rush, F.E., Thordarson, William, and Pyles, D.G., 1984, Geohydrology of test well USW H-1, Yucca Mountain, Nye County, Nevada: U.S. Geological Survey WaterResources Investigations Report 84-4032, $56 \mathrm{p}$.

Seber, G.A.F., and Wild, C.J., 1989, Nonlinear regression: New York, John Wiley, $768 \mathrm{p}$.

Sinton, P.O., 1987, Three-dimensional, steady-state, finitedifference model of the ground-water flow system in the Death Valley ground-water basin, NevadaCalifornia: Golden, Colorado School of Mines, Master's thesis, $145 \mathrm{p}$.

Smith, D.R., and Paradis, A.R., 1989, Three-dimensional GIS for the earth sciences, in Raper, Jonathan, ed., Three dimensional applications in Geographic Information Systems: London, Taylor and Francis, p. 149-154.

Smith, R.B., and Sbar, M.L., 1974, Contemporary tectonics and seismicity of the western United States with emphasis on the intermountain seismic belt: Geological Society of America Bulletin, v. 85, p. 1205-1218. 
Stewart, J.H., 1971, Basin and range structure-A system of horsts and grabens produced by steep-sided extension: Geological Society of America Bulletin, v. 82, p. 1019-1044.

1978, Basin and range structure in North America-A review, in Smith R.B., and Eaton, G.P., eds., Cenozoic tectonics and regional geophysics in the western Cordillera: Geological Society of America Memoir 152 , p. 1-31.

1980, Geology of Nevada: Nevada Bureau of Mines and Geology Special Publication 4, $136 \mathrm{p}$.

Stewart, J.H., and Carlson J.E., 1978, Geologic map of Nevada: U.S. Geological Survey Map, 2 sheets, scale 1:500,000.

Strand, R.G., 1967, Geologic map of California-Mariposa sheet: California Division of Mines and Geology, scale $1: 250,000$.

Streitz, Robert, and Stinson, M.C., 1974, Geologic map of California-Death Valley sheet: California Division of Mines and Geology, scale 1:250,000.

Thomas, J.M., Mason, J.L., and Crabtree, J.D., 1986, Ground-water levels in the Great Basin region of Nevada, Utah, and adjacent States: U.S. Geological Survey Hydrologic-Investigations Atlas HA-694-B, scale $1: 1,000,000$.

Thomas, J.M., Schaefer, D.H., and Dettinger, M.D., 1990, Use of geochemical data to trace ground-water flow, which could affect oil migration, in carbonate-rock aquifers of the eastern Great Basin, Nevada and Utah, in oil fields and geology of the Pine Valley, Eureka County area Nevada, in Flanigan, Donna, M.H., Larry J. Garside, and Mike Hansen, eds., Nevada Petroleum Society 1990 Fieldtrip Guidebook: Reno, Nevada Petroleum Society, $56 \mathrm{p}$.

Thordarson, William, 1983, Geohydrologic data and test results from well J-13, Nevada Test Site, Nye County, Nevada: U.S. Geological Survey Water-Resources Investigations Report 83-4171, $57 \mathrm{p}$.

Thordarson, William, and Robinson, B.P., 1971, Wells and springs in California and Nevada within 100 miles of the point $37^{\circ} 15^{\prime}$ north, $116^{\circ} 25^{\prime}$ west, on the Nevada Test Site: U.S. Geological Survey Report 474-85, $178 \mathrm{p}$.

Thordarson, William, Rush, F.E., Spengler, R.W., and Waddell, S.J., 1984, Geohydrologic and drill-hole data for test well USW H-3, Yucca Mountain, Nye County, Nevada: U.S. Geological Survey Open-File Report 84-149, 28 p.

Thordarson, William, Young, R.A., and Winograd, I.J., 1967, Records of wells and test holes on the Nevada Test Site and vicinity (through December 1966): U.S. Geological Survey Trace Elements Investigations 872, $26 \mathrm{p}$.
Turner, A.K., ed., 1989, The role of three-dimensional geographic information systems in subsurface characterization for hydrogeological applications, in Raper, Jonathan, ed., Three dimensional applications in Geographic Information Systems: London, Taylor and Francis, p. 115-127.

1991, Three-dimensional modeling with geoscientific information systems-NATO ASI Series C, Mathematical and Physical Sciences, v. 354: Dordrecht, The Netherlands, Kluwer Academic Publishers, $443 \mathrm{p}$.

1992, Applications of three-dimensional geoscientific mapping and modeling systems to hydrogeological studies, in Turner, A.K., ed., Three-dimensional modeling with geoscientific information systems-NATO ASI Series C, Mathematical and Physical Sciences, v. 354: Dordrecht, The Netherlands, Kluwer Academic Publishers, p. 327-364. 1996a, Digital Elevation Model (DEM) file of topographic elevations for the Death Valley Region of southern Nevada and southeastern California processed from U.S. Geological Survey 1-degree digital elevation model data files: U.S. Geological Survey Open-File Report 95-287, 9 p.

1996b, Digital hydrographic, land use/land cover, and hydrogeologic unit boundary files for the Death Valley region of southern Nevada and southeastern California processed from U.S. Geological Survey $1: 100,000$, and 1:250,000-scale digital data files: U.S. Geological Survey Open-File Report 95-362, 21 p.

Turner, R.M., and Bawiec, W.J., 1991, Digital geologic coverage of Nevada - A digital representation of the 1978 geologic map of Nevada: U.S. Geological Survey Digital Data Series 2.

U.S. Department of Agriculture, 1991, State Soil Geographic Data Base (STATSGO) Data Users Guide: Soil Conservation Service Miscellaneous Publication No. $1492,87 \mathrm{p}$.

Waddell, R.K., 1982, Two-dimensional, steady-state model of ground-water flow, Nevada Test Site and vicinity, Nevada-California: U.S. Geological Survey WaterResources Investigations Report 82-4085, $72 \mathrm{p}$. -1984 , Hydrologic and drill-hole data for test wells UE-29a\#1 and UE-29a\#2, Fortymile Canyon, Nevada Test Site: U.S. Geological Survey Open-File Report 84-142, $25 \mathrm{p}$.

Waddell, R.K., Robison, J.H., and Blankennagel, R.K., 1984, Hydrology of Yucca Mountain and vicinity, Nevada-California - Investigative results through mid1983: U.S. Geological Survey Water-Resources Investigations Report 84-4267, $72 \mathrm{p}$. 
Walker, G.E., and Eakin, T.E., 1963, Geology and ground water of Amargosa Desert, Nevada-California: Carson City, Nevada Department of Conservation and Natural Resources, Ground-Water Resources-Reconnaissance Series Report 14, $45 \mathrm{p}$.

West, N.E., 1989, Intermountain desert, shrub steppes, woodlands, in Barbour, M.G., and Billings, W.D., eds., North American terrestrial vegetation: Cambridge, United Kingdom, Cambridge University Press, 434 p.

Whitfield, M.S., Jr., Eshom, E.P., Thordarson, William, and Schaefer, D.H., 1985, Geohydrology of rocks penetrated by test well USW H-4, Yucca Mountain, Nye County, Nevada: U.S. Geological Survey WaterResources Investigations Report 85-4030, 33 p.

Whitfield, M.S., Jr., Thordarson, William, and Eshom, E.P., 1984, Geohydrologic and drill-hole data for test well USW H-4, Yucca Mountain, Nye County, Nevada: U.S. Geological Survey Open-File Report 84-449, 39 p.

Winograd, I.J., 1962, Interbasin movement of ground water at the Nevada Test Site, Nevada, in Short papers in geology and hydrology: U.S. Geological Survey Professional Paper 450-C, p. 108-111.

-1971, Origin of major springs in the Amargosa Desert of Nevada and Death Valley, California: Tucson, University of Arizona, Ph.D. dissertation, 170 p.

Winograd, I.J., and Friedman, Irving, 1972, Deuterium as a tracer of regional ground-water flow, southern Great Basin, Nevada-California: Geological Society of America Bulletin, v. 83, no. 12, p. 3591-3708.

Winograd, I.J., and Pearson, F.J., Jr., 1976, Major carbon 14 anomaly in a regional carbonate aquifer-Possible evidence for mega scale channeling, south-central Great Basin: Water Resources Research, v. 12, no. 6, p. 1125-1143.

Winograd, I.J., and Szabo, B.J., 1988, Water-table decline in the south-central Great Basin during the Quaternary Period-Implications for toxic waste disposal, in Carr, M.D. and Yount, J.C., eds., Geologic and hydrologic investigations of a potential nuclear waste disposal site at Yucca Mountain, southern Nevada: U.S. Geological Survey Bulletin 1790, p. 147-152.

Winograd, I.J., Szabo, B.J., Coplen, T.B., Riggs, A.C., and Kolesar, P.T., 1985, Two-million-year record of deuterium depletion in Great Basin ground waters: Science, v. 227, p. 519-522.

Winograd, I.J., and Thordarson, William, 1975, Hydrologic and hydrochemical framework, south-central Great Basin, Nevada-California, with special reference to the Nevada Test Site: U.S. Geological Survey Professional Paper 712C, p. C1-C126. 